



\title{
Interseções entre arte e arquitetura. O caso dos pavilhões
}

\author{
Ana Carolina Tonetti
}

Dissertação de Mestrado apresentada a Faculdade de Arquitetura e Urbanismo da Universidade de São Paulo para a obtenção do título de Mestre em Arquitetura e Urbanismo.

Área de Concentração:

Projeto, Espaço e Cultura

Orientador:

Prof. Dr. Agnaldo Aricê Caldas Farias

São Paulo

2013 
Autorizo a reprodução e divulgação total ou parcial deste trabalho, por qualquer meio convencional ou eletrônico, para fins de estudo e pesquisa, desde que citada a fonte.

e-mail: actonetti@gmail.com

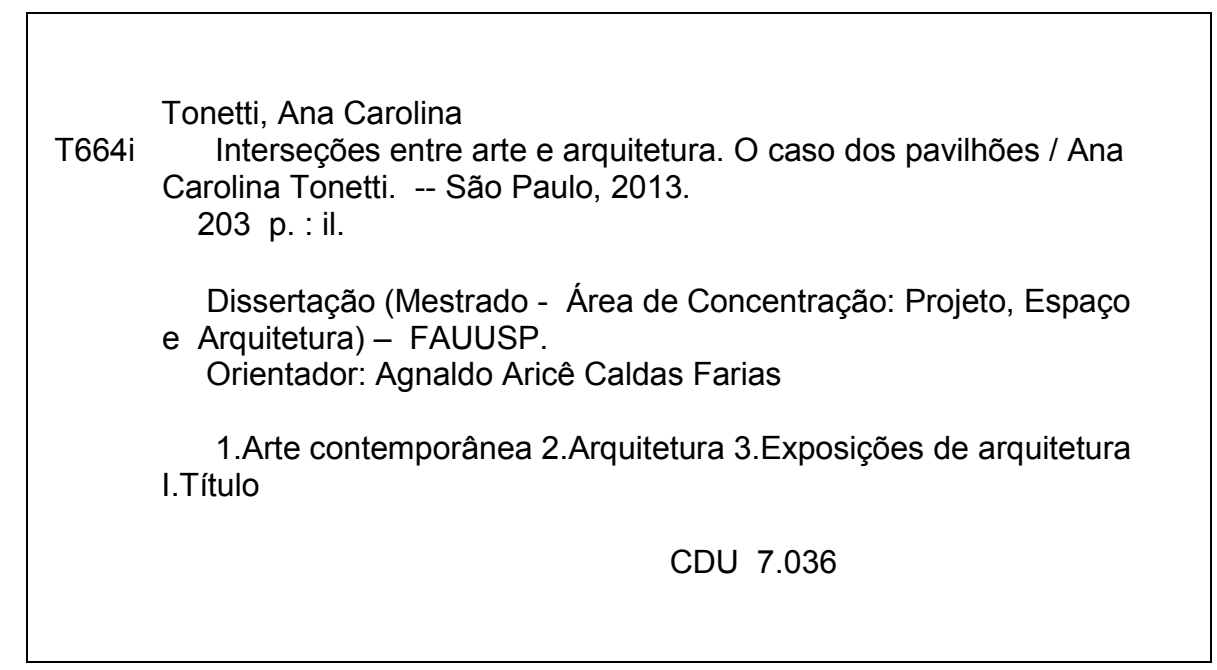




\section{Agradecimentos}

Agradeço à Fundação de Amparo a Pesquisa do Estado de São Paulo (FAPESP), pelo apoio financeiro indispensável para realização deste trabalho.

Ao professor Agnaldo Farias, meu orientador, por ter me acolhido no Programa de Pós-graduação da FAU-USP e contribuído de forma sempre precisa ao desenvolvimento do trabalho.

Sou grata a diversas pessoas que contribuíram com o material coletado e aqui apresentado: Paula Zasnicoff pela disponibilidade e conversa, cedendo material essencial, sempre retornando com agilidade e atenção; Rodrigo Moura, por autorizar a divulgação de material processual dos projetos arquitetônicos do Inhotim; os escritórios Aires Mateus e Eduardo Souto de Moura, pela rapidez e gentileza na liberação dos projetos para Bienal de Veneza de 2012.

Agradeço também a pessoas que contribuíram direta e indiretamente para o trabalho: Marta Bogéa e Fernanda Fernandes pelas observações e correções de rumo que surgiram a partir da banca de qualificação. À Carla Caffé e Keila Costa, pela parceria que me permitiu a dedicação necessária a este trabalho. Ao Pedro Mauger que me poupou no período de reclusão total. À Sophia S. Telles pelas conversas entusiasmadas e muito bem humoradas. Ao Flávio Lembo pela gentil e paciente leitura. À Denise Lembo com a ajuda na reta final.

Ao Zé Grellet e meus pais, sempre presentes.

Ao André, pelo estímulo primordial, as incansáveis revisões e a companhia que me motiva. 



\section{Resumo}

Esta dissertação tem como foco central o estudo de edifícios pavilhões e sua relação com a produção tridimensional - entendida como instalação e escultura. Para tanto, articula-se o conceito de "campo ampliado", elaborado por Rosalind Krauss em texto de 1979 para abarcar as transformações da escultura a partir dos anos 60, com seu recente deslocamento, para o âmbito da arquitetura por parte de alguns autores, nomeadamente Antony Vidler.

A pesquisa não se resume apenas a uma investigação da contribuição do espaço arquitetônico para a escultura ou da escultura para a arquitetura, mas foca especialmente a linha que as separa, visto que a tendência de convergência das duas disciplinas faz com que seu elo de reciprocidade se dissolva numa produção intersticial, realizada por artistas, arquitetos ou mesmo por ambos em colaboração.

O pavilhão sempre foi entendido como um campo experimental para os arquitetos, especialmente ao longo do século XX quando ajudou a consolidar as premissas da arquitetura moderna. Hoje, apresenta grande visibilidade através de diversos programas que oferecem condições únicas de encomenda e concepção pressupondo uma arquitetura singular, que configura uma produção desvinculada do binômio forma-função e cujo assunto autorreferente é a própria arquitetura. Do ponto de vista das artes o pavilhão representa uma expansão da instalação para um todo espacial que passa a envolver também o edifício e, quando tomado como meta arquitetura, opera também como plataforma de afrontamento crítico.

O embate teórico acerca dos desdobramentos do "campo ampliado", bem como a investigação sobre aspectos essenciais do termo "pavilhão", de natureza maleável, são confrontados com uma análise crítica de casos selecionados em três instituições com características bem distintas- Bienal de Veneza, Instituto de Arte Contemporânea do Inhotim e Serpentine Gallery -, e possibilitam alinhavar conclusões sobre esta produção contemporânea no limiar dessas duas disciplinas.

Palavras chave: pavilhão, campo ampliado, arquitetura, arte contemporânea, exposições de arquitetura, Bienal de Veneza, Inhotim, Serpentine Gallery. 



\section{Abstract}

This dissertation is focused on the study of pavilions and their relationship with the three-dimensional production - understood as installation and sculpture. Therefore, the concept of "expanded field", elaborated by Rosalind Krauss in the 1979 essay to encompass the transformation of sculpture from the 60's, is articulated with the recent shift of this same concept into the realm of architecture by some authors, namely Antony Vidler.

The research is not just an investigation on the contribution of the architectural space for sculpture or, on the other hand, from sculpture to architecture, but focuses especially the line that separates them, understood as a disposition of convergence by the two disciplines which dissolves the reciprocal bonds in a interstitial production, performed by artists, architects or even both together.

The pavilion has always been understood as an experimental field for architects, especially during the twentieth century when it helped consolidate the assumptions of modern architecture. Today it has gained great visibility through several programs that offer specific conditions by commissioning and assuming a unique architecture design that sets up a production untied from the binomial form-function, resulting in a self referent building whose subject is the architecture itself. From the point of view of the arts, it represents an expansion of the installation configuring a spatial whole that also implicate the building and, when taken as meta architecture, also operates as a platform for critical confrontation.

The opposition on theory about the ramifications of the expanded field, as well as a research on the essential characteristics to a malleable term, are faced with a critical analysis of selected cases in three institutions gathering rather distinct characteristics - the Venice Biennale, the Institute of Contemporary Art Inhotim and the Serpentine Gallery -, and allow conclusions on this contemporary production in a disciplinary threshold.

Key words: pavilion, expanded field, architecture, contemporary art, architecture exhibition, Venice Biennale, Inhotim, Serpentine Gallery. 



\section{Sumário}

Introdução 13

Parte I: Dos Conceitos, do Objeto e da História.

1.Pavilhão e Campo Ampliado.

1.1 Campo Ampliado: um sintoma. $\quad 19$

1.2 Pavilhão. 26

1.3 Os Pavilhões de Sonsbeek. 29

1.4 O espaço de exibição como exibição do espaço. $\quad 37$

2.Da arte para a arquitetura, da arquitetura para a arte.

2.1 Limites arquitetônicos. 43

2.2 Plataformas operacionais. 49

2.3 Instalação: a arquitetura dentro da arquitetura. $\quad 55$

2.4 Espaço de reflexão. $\quad 61$

De Mies Van der Rohe a Dan Graham.

Parte II: Análise de casos.

\section{Bienal de Veneza.}

3.1 Os pavilhões do Giardino.

3.2 Atmosfera e Instalação. $\quad 88$

3.3 A Bienal de 1980 e o Teatro Del Mondo. 104

\section{Inhotim.}

4.1 Museu e paisagem. 109

4.2 Uma galeria para uma obra específica. 118

4.3 Doug Aitken e Matthew Barney. 122

4.4 Pavilhão Adriana Varejão. 139

\section{Serpentine Gallery.}

5.1 O programa de pavilhões, arquitetura e curadoria. 147

5.2 Rem Koolhaas - 2006. 155

5.3 SANAA - 2009. 165

5.4 Herzog \& De Meuron e Ai Weiwei - 2012. 171

6.Considerações finais. 181

7.Referências bibliográficas. 187

8. Índice de imagens. 



\section{Introdução}

\section{Não é bem um edifício.}

A virada do milênio coincide com um momento em que a arquitetura retoma o foco das atenções no cenário cultural contemporâneo com a inauguração e repercussão de algumas obras espetaculares, e esta retomada de interesse na arquitetura parece encontrar um curioso paralelo no fenômeno da superexposição de pavilhões. O pavilhão está na ordem do dia, surge como grande evento midiático itinerante para a promoção da identidade de corporações internacionais, é construído por estudantes como exercício de atividades acadêmicas, pode ser comissionado para temporadas de verão por consagradas instituições artísticas preocupadas em apresentar um programa de exposições voltado para a arquitetura, ou mesmo, colecionado como obra de arte e adquirido por instituições que os expõem como grandes instalações artísticas, estes edifícios extrapolam os limites físicos dos museus e centros de exposição para conquistarem pátios, parques e as ruas, e demonstram uma força escultórica da arquitetura operando não como suporte expositivo, mas como o objeto exposto.

Operando na natureza essencial da disciplina, com programa simplificado e flexível, os pavilhões sempre se apresentaram como uma área estratégica de atuação da arquitetura e possibilitaram, ao longo da história do século XX, principalmente no contexto das feiras mundiais, a materialização e divulgação de novos conceitos culminando numa grande produção de obras canônicas que ajudaram a consolidar a arquitetura moderna, a exemplo do Pavilhão de Barcelona (1929), projeto de Mies Van der Rohe, uma das mais emblemáticas obras da arquitetura do período cuja importância motivou sua reconstrução em 1986 com status de monumento histórico. 
Por possuírem uma lógica interna própria, com condições de encomenda e concepção que pressupõe uma arquitetura singular, sendo geralmente temporário e com utilidade questionável, estes edifícios apresentam um conceito sobre a construção, uma ideia sobre novos programas e usos, ou uma representação prototípica de potenciais construtivos o que faz com que sejam reconhecidos como obras especulativas e de limite disciplinar.

Partindo desta premissa, este trabalho oferece uma visada sobre esta retomada de interesse no pavilhão inferido como um fértil campo de estudo dos interesses partilhados entre arte e arquitetura, especialmente se esta produção for analisada e relacionada ao conceito de "campo ampliado", elaborado por Rosalind Krauss, em 1979, para tratar das transformações da escultura a partir dos anos 60 , e seus recentes desdobramentos e deslocamento também para o âmbito da arquitetura por alguns autores, numa clara demonstração que, do mesmo modo que a arquitetura em alguns casos aproxima-se da escultura, também esta é estimulada a aproximar-se da arquitetura. Este processo de reciprocidade será investigado não somente de um ponto de vista da contribuição do espaço arquitetônico como estímulo ou interferência para a produção tridimensional - entendida como escultura e instalação - mas também através de seu inverso, buscando explicitar a tendência de convergência representada pelo pavilhão, que hoje é igualmente produzido por artistas e arquitetos, ou mesmo por ambos, trabalhando em colaboração.

Diversos exemplos ilustram estas variadas manifestações que passam a instituir "coleções" de arquiteturas em ambientes controlados e museológicos. A começar pelo “Kröller-Müller Museum”, na Holanda, que representa um paradigma de interação entre paisagem, escultura e arquitetura desde 1938, tendo reconstruído os importantes pavilhões de Rietveld (1954-1965) e Aldo Van Eyck (1966-2006) como monumentos arquitetônicos, o "Benesse Art site Naoshima", no Japão, que dilui sua coleção ao longo de três ilhas e convida artistas e arquitetos a realizarem intervenções especificamente para o local interagindo com a comunidade residente, ou mesmo a iniciativa do artista Ai Weiwei que no "Jinhua Architecture Park", na China, levou ao extremo este conceito e convidou dezesseis arquitetos a projetarem pavilhões, alguns destinados a receberem restaurantes e exposições, 
outros sem qualquer uso ou finalidade a não ser o de proporcionarem pontos de vista e conduzirem o percurso, proporcionando experiências espaciais ao longo do parque linear que homenageia o poeta Ai Qing, pai do artista/arquiteto.

Essa população híbrida e crescente de produtores e colecionadores de pavilhões leva também à necessidade de se retomar o próprio termo, cuja acepção maleável ganha contornos e usos variados de acordo com o contexto. Não se trata mais de apenas uma pequena construção temporária, mas em diversas ocasiões refere-se a uma construção autônoma, conectada ou relacionada a um conjunto maior de edifícios, podendo ser utilizada como galeria ou como mero espaço coberto e escultural em meio a um jardim ou situação urbana e, assim como a escultura na década de 60 , passa a ser mais fácil defini-lo pela sua característica negativa, ou "aquilo que não é bem um edifício".

\section{A estrutura da dissertação.}

O processo de pesquisa revelou, após o percurso de um amplo arco temporal com vistas a documentar uma parte da produção pavilionar, que o estudo deveria priorizar a premissa teórica e focar na tendência de convergência dos campos, assim, o recorte busca refletir a atualidade do tema que se desenvolve com maior potência a partir do segundo quartel do século XX.

Historia e Teoria são dois universos entrelaçados ao longo da primeira parte da dissertação que é dividida em dois capítulos. No primeiro capítulo será apresentado o conceito de campo ampliado e seus desdobramentos que, cotejados a alguns casos exemplares, pretendem alinhavar os argumentos apresentados e contribuir para o entendimento de uma importante inflexão: como o programa arquitetônico gradualmente perde sua relevância e muda o foco do que é exposto, do interior do pavilhão para o pavilhão em si. No segundo capítulo, função e programa são tratados como características essenciais à disciplina arquitetônica que, quando tensionados, contextualizam um campo híbrido de atuação que passa por um entendimento do termo instalação e uma análise da obra do artista Dan Graham, que parte da arquitetura de Mies Van der Rohe como ícone catalisador de uma discussão, para obter um conjunto singular de mais de cinquenta 
“esculturas pavilhões”, só compreendidas se analisadas em meio a um campo ampliado de debate, estruturado por uma rede de interação entre arte e arquitetura.

A segunda parte do trabalho, dividida em três capítulos, apresenta o maior peso da pesquisa que, para se desenvolver, seguiu o direcionamento de um mapeamento e análise de casos selecionados entre programas e instituições que das mais diversas maneiras exibem o pavilhão como uma arquitetura autorreferente. A começar pela Bienal de Veneza, no terceiro capítulo, onde os pavilhões do Giardino narram e repassam uma parte da história dos pavilhões relacionados a seu caráter simbólico de representação nacional e seu uso como galeria em constante transformação pelas intervenções de artistas e arquitetos, possibilitando também uma reflexão sobre a instalação de arte, sua apropriação pelos arquitetos e a consolidação das exposições de arquitetura a partir de seu primeiro e maior evento: a Bienal de Arquitetura de Veneza.

O quarto capítulo trata do Instituto de Arte Contemporânea do Inhotim onde, partindo de uma análise das condições do museu jardim e de sua coleção, é possível se verificar, num contexto nacional, diversos processos de interação e colaboração que possibilitam aos artistas condições singulares de controle espacial da obra, seja por sua escala ou por sua condição topológica, a obra é o lugar e a arquitetura, neste caso, o pavilhão.

Por último, o programa de pavilhões da Serpentine Gallery, em Londres, proporciona aos arquitetos uma conjuntura de fatores particulares: a ausência de programa, temporalidade e orçamento garantido, comissionado por um museu interessado na experimentação de uma obra de arquitetura única não relacionada à exibição de uma obra artística. Com isso, instiga a subjetividade de boa parte dos participantes a se projetar aproximando-se de procedimentos artísticos gerando uma produção distinta que abre uma discussão sobre a autonomia do pavilhão como projeto intelectual descolado da realidade profissional refletindo a tendência de uma formalização cada vez mais escultórica da arquitetura contemporânea. 
Parte I:

\section{Dos conceitos, do Objeto, e da História.}





\section{Pavilhão e Campo Ampliado}

\subsection{Campo Ampliado: um sintoma.}

Em 1979, a crítica e historiadora da arte Rosalind Krauss publica o texto "Sculpture in the Expanded Field" no oitavo volume da revista October - publicação que ajudou a fundar e consolidar como um dos mais importantes periódicos de vanguarda na crítica de arte contemporânea. Naquele período, final dos anos 60 e ao longo dos 70 , profundas transformações questionavam as categorias tradicionais das artes visuais - especialmente a pintura e a escultura -, e provocavam uma expansão e reconfiguração de limites disciplinares tendendo a estabelecer um campo de experiências partilhadas entre a arquitetura e a arte demandando novos métodos e conceitos para um entendimento da categoria escultura na pós-modernidade.

Diante deste cenário, em andamento no ambiente norteamericano, a land-art propõe o abandono da galeria e se lança em direção as grandes extensões territoriais incorporadas à escultura através de radicais intervenções na paisagem ${ }^{1}$, enquanto o minimalismo reativa o readymade duchampiano como forma de esvaziar qualquer significado da forma, utilizando-se de materiais produzidos em série que recombinados em sua simples exterioridade incorporavam o espaço arquitetônico, continente da obra, em sua pura literalidade ${ }^{2}$. Ambos os procedimentos pressupunham a passagem do corpo como ato essencial à experimentação espacial da obra e, com isso, dão sequência

1 Servem como exemplo as enormes fendas temporárias abertas por Michael Heizer no deserto em "Duplo Negativo" (1969), ou o quebra-mar espiral realizado por Robert Smithson no Grande lago salgado de Utah, a "Spiral Jetty" (1970).

2 Dan Flavin é o exemplo mais significativo do processo de se revelar o espaço do museu ou galeria, e mesmo de subvertê-lo, pois ao instalar seus conjuntos de lâmpadas fluorescentes industrializadas, muitas vezes em meio a outras obras, alterava a neutralidade da galeria e com isso corrompia sua função e uso arquitetônico, dramatizando o espaço expositivo. 
ao processo iniciado por Brancusi e Rodin nos primórdios da escultura moderna que, segundo Krauss, proporcionavam uma "relocação do ponto de origem do significado do corpo" e assim configuravam "um ato radical de descentralização, que incluiria o espaço em que o corpo se fazia presente no momento de seu aparecimento"3.

Se a escultura em meio a este processo tornara-se "aquilo em que se tropeça ao se distanciar para ver uma pintura" ${ }^{4}$, sendo mais fácil entendê-la pelas suas características negativas - aquilo em frente ao, ou, no edifício que não é o edifício, ou inserido na paisagem sem ser paisagem ${ }^{5}$ - um novo sistema de valores precisava ser configurado, de forma a positivar a oposição destas negativas, bem como aceitar a inserção dos termos paisagem e arquitetura como definidores da escultura $^{6}$, que em seu atual estado encontrava-se completamente imbricada a seu entorno. Utilizando um diagrama de Klein ${ }^{7}$, Krauss obtém como resultado da expansão lógica destes termos binários três novos campos quaternários e complexos: o sítio-construção, o sítio-demarcado e a estrutura axiomática - expressões de um campo ampliado da escultura de acordo com o gráfico 1.

Dentre estas resultantes a estrutura axiomática se direciona num sentido de expansão dos limites disciplinares da arte para uma aproximação da arquitetura onde intervenções no espaço arquitetônico, de forma parcial ou total, estabelecem o ponto de contato que leva Anthony Vidler - crítico e historiador de arquitetura norte-americano - a propor, vinte cinco anos depois, no texto “Arquitecture's expanded filed: finding inspiration in jellyfish and geopolitics, architecture today are

3 KRAUSS. 2007, p.333.

4 Barnett Newman, artista norte-americano ligado à pintura abstrata expressionista. (NEWMAN Apud KRAUSS 1979, p. 34.)

5 KRAUSS. Op. cit., p.35.

6 Krauss ressalta a proibição ideológica de se assumir os termos paisagem e arquitetura como possíveis geradores de definições para escultura, especialmente se considerarmos os escritos de Clement Greenberg e Michael Fried que buscavam estabelecer normas que desvinculassem qualquer relação entre arte e arquitetura.

7 Grupo de Klein é um procedimento matemático que foi adaptado pelo psicólogo estruturalista Jean Piaget para aplicação nas ciências humanas. Parte de um grupo de quatro elementos e um conjunto de quatro operações mentais mutuamente relacionadas por leis de composição que constituem uma estrutura matemática do grupo onde, duas relações são de pura contradição e representadas por uma seta cheia, duas relações de contradição expressas como involução, representadas por duas setas cheias e duas relações de implicação representadas pelas linhas tracejadas. 


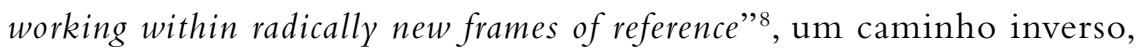
desta vez, percorrido pela arquitetura que na sua atual condição exploratória, atingida na última década do século XX, estaria também tendendo a esta linha de convergência. Assim, para que a arquitetura conseguisse obter este caráter exploratório e buscar uma reconstrução de suas fundações disciplinares, alguns dualismos atávicos como forma e função, historicidade e abstração, utopia e realidade, e estrutura e vedação tiveram que ser superados para que novos princípios estruturadores pudessem emergir, e pela recombinação da arquitetura e paisagem, arquitetura e biologia, e arquitetura e programa seria possível encontrar três novas possibilidades para a estrutura axiomática que configuram um campo ampliado arquitetônico.

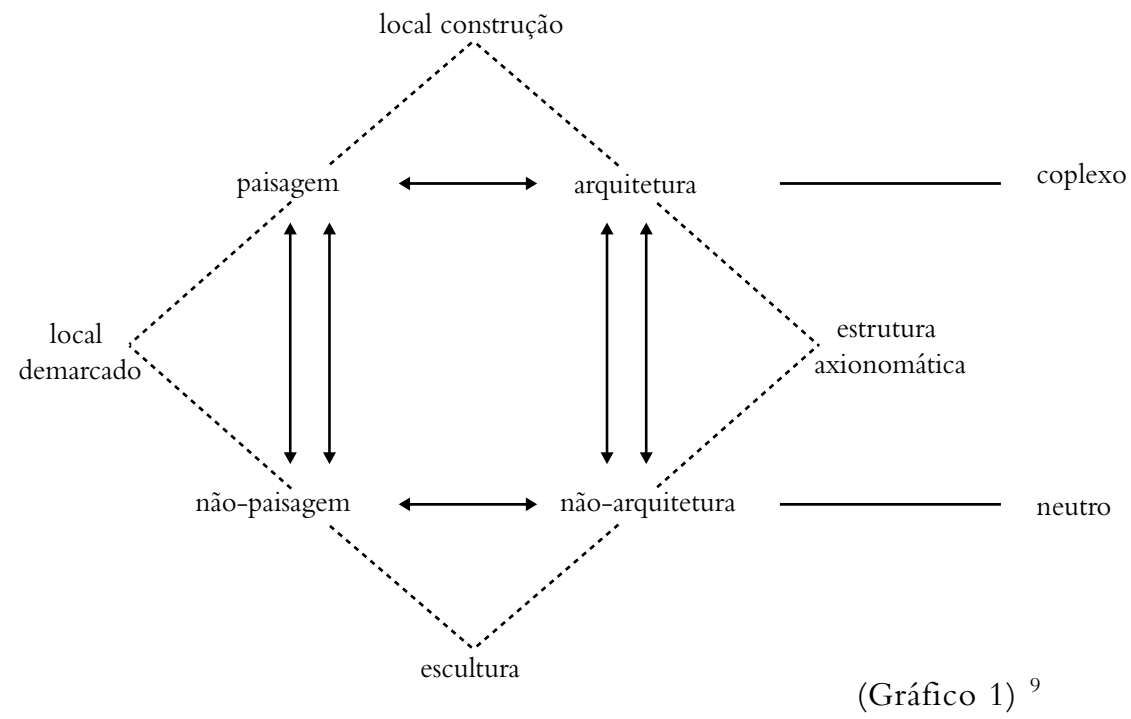

Ambos os autores lidam com a interpretação de situações contemporâneas e buscam estabelecer novos parâmetros para interpretação desse fenômeno de estreitamento entre arte e arquitetura, sendo o campo ampliado, apenas uma primeira e significativa resposta ao sintoma, um ponto de partida na tentativa de abarcar esta produção multifacetada da qual os pavilhões proporcionam um recorte potente

8 VIDLER, Anthony. In: Artforum International Magazine Vol. 42. 2004, pp. 147-150.

9 Os termos: "marked-sites"- local demarcado - "site-construction"- local construção -, e "axionomatic structure"- estrutura axiomática, utilizados no gráfico, baseiam-se na tradução "Escultura no Campo Ampliado" realizada por Elizabeth Carbone Baer publicado na Revista Gávea $n^{\circ} 1$ da PUC-RJ. 

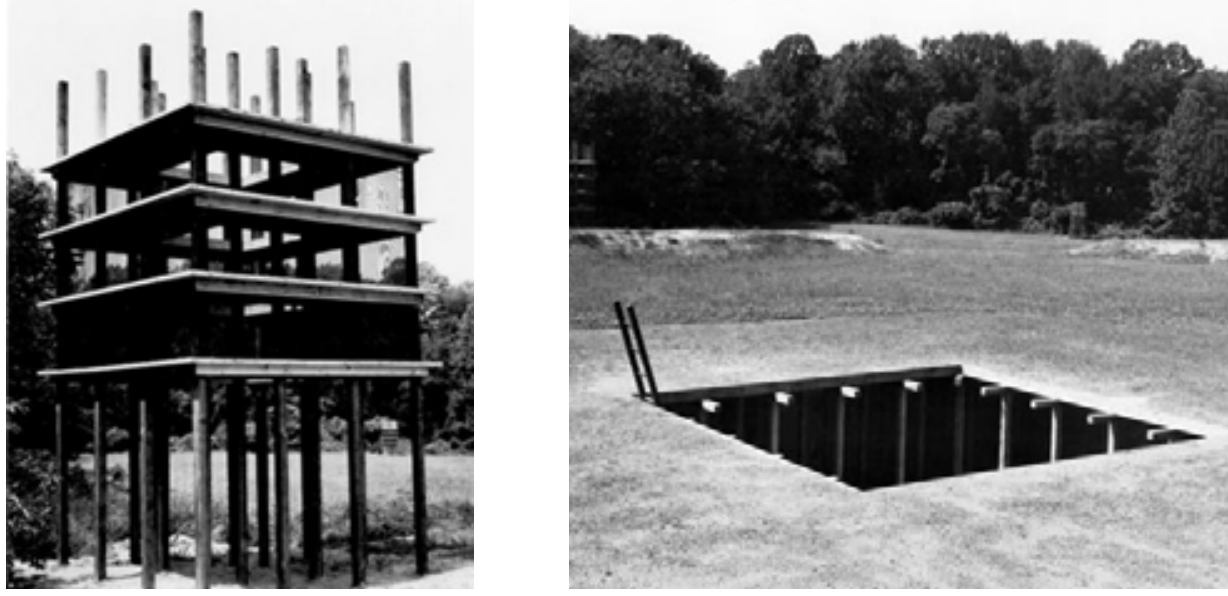

figuras 1 e 2

Mary Miss. Perimeters/Pavillions/Decoys. 1977-1978

(Nassau County, Long Island, Nova Iorque) 
de investigação dessas aproximações e tendências de convergência.

O pavilhão é o assunto de diversos artistas, a partir da década de 70, que dão novos contornos e usos ao termo ao implantá-los dentro das galerias, como uma construção dentro da construção, ou fora das galerias, numa tendência comentada por Silvia Lavin como uma espécie de hipertrofia da instalação artística que, recentemente, cada vez mais, se expande do espaço da galeria para o edifício em $\mathrm{si}^{10}$.

Não se trata de casualidade, portanto, que dentre as obras de artistas analisadas pelo campo ampliado artístico encontremos "Perimeters, Pavilions/Decoys" (1978 - figuras 1 e 2 ) de Mary Miss ${ }^{11}$ e na contrapartida arquitetônica seja destacada a produção do escritório norte-americano Diller + Scofidio \& Renfro, cujo pavilhão temporário para a Expo 2002, na Suíça, consegue a um só tempo articular os três princípios de expansão do campo ampliado arquitetônico proposto por Vidler.

$$
\text { O “Blur Building”(figura 3), do escritório Diller + Scofidio }
$$

$\&$ Renfro, parte da paisagem do lago Neuchatel, para construir um edifício que se desmaterializa como uma nuvem sobre o lago, propondo um continuum entre paisagem e construção conformado não somente pela sua inserção visual, mas pela interação de fenômenos naturais e tecnologia de ponta. A estrutura tubular de aço, montada em meio ao lago, não era a geradora de uma unidade formal, mas apenas o suporte para trinta e um mil e quinhentos pequenos borrifadores de água ligados a um sistema "inteligente" de leitura do clima, que detectava as mudanças do clima e captava a água do lago de forma a gerar uma névoa mais ou menos densa e sem forma, massa, superfície, dimensão, escala, ou delineamento. Ou seja, essa massa informe era resultante não de um programa ou funções pré-estabelecidas ou de um sistema estrutural, mas sim de uma tecnologia capaz de interpretar a informação climática coletada e decodificá-la em um fenômeno natural mimetizando construção e entorno. Os espectadores eram conduzidos

10 LAVIN.2012, p. 214.

11 O trabalho consiste de três torres de estruturas semelhantes, dois montes semicirculares, e um pátio subterrâneo, construído usando técnicas de construção vernaculares de forma a estabelecer percursos e relações de escala em um parque que faz parte do Museu de Long Island que é utilizado por moradores locais. 


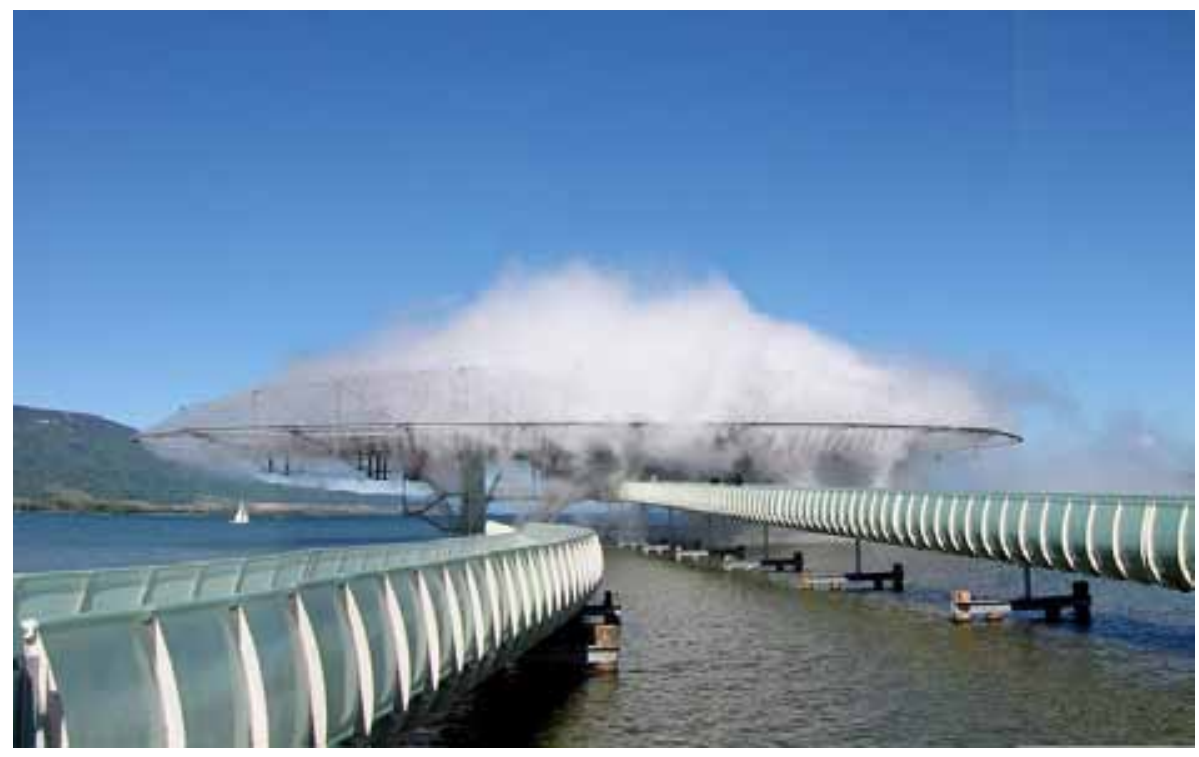

figura 3

Diller Scofidio + Renfro. Blur Building, 2002.

(Lago Neuchatel, Yverdon-les-Bains, Suíça) 
a essa nuvem suspensa sobre o lago por uma plataforma de acesso e, à medida que se aproximavam do edifício, sentiam-se desestabilizados pelo efeito embaçado e fora de foco desta atmosfera provocadora de outros sentidos - o tato estimulado pelo contato da umidade sobre a pele, ou mesmo o paladar, uma vez que podiam provar o sabor da água - desestabilizando a visão e possibilitando um posicionamento crítico tanto frente ao tema proposto pela exposição ${ }^{12}$ quanto à própria arquitetura e a maneira como é consumida atualmente, apenas pela imagem que é capaz de criar. O "Blur Building” resiste a definições e coloca-se claramente em meio a uma discussão ampliada onde seus autores o definem não como um edifício, mas sim como uma "atmosfera".

Arte e arquitetura apresentam-se cada vez mais conectadas pela ideia do pavilhão, que realizado por arquitetos e por artistas, ou por colaboração entre ambos, fundem contentor espacial e conteúdo e, a partir de um ponto de vista do campo disciplinar arquitetônico, esta produção híbrida coloca o pavilhão numa condição de reprodução da negatividade detectada por Krauss na produção tridimensional das décadas de 60 e 70, ao expressar com maior veemência aquilo que não é. Assim, hoje se observa uma enorme maleabilidade com o emprego do termo pavilhão, utilizado, via de regra, para denominar "aquilo que não é bem um edifício"13, sendo, então, importante retomar historicamente um entendimento de se seus atributos.

12 O tema da exposição tratava de relacionar a interação entre tecnologia e sustentabilidade na exploração de recursos naturais, oferecendo visões de um futuro possível.

13 Silvia Lavin usa esta expressão para qualificar a estrutura de madeira "Metropol Parasol" (2011), projeto de Jürgen Mayer para Sevilha, que consiste apenas de uma grande cobertura sobre uma praça e um passeio público elevado. Sob a praça, semienterrado, encontra-se um sítio arqueológico. Op. cit. p.215. 


\subsection{Pavilhão}

Pavilhão é um termo derivado do francês pavillon que por sua vez reporta-se ao latim papilionem e significa borboleta, ou no latim tardio, tenda, que se estica como borboleta ao pousar. Logo, etimologicamente, está estritamente relacionado à sua característica transiente e inconstante de leve estrutura que transforma onde delicadamente se fixa.

A necessidade de abrigos que pudessem ser desmontáveis e transportados, especialmente em investidas militares de conquista e expansão territorial desde a história da antiguidade, é entendida como uma das origens do pavilhão que, desde então, sempre esteve relacionado à noção de programa simplificado e mobilidade. Registros apontam para um conhecimento deste tipo de estrutura na Europa desde o período do antigo Egito, e reitera seu uso militar durante o medievo como um padrão de estrutura composta de duas partes, compreendendo cortinas e telhado, utilizado para a proteção do soberano ${ }^{14}$.

A popularidade dessas construções na Europa amplia-se consideravelmente no século XVII pelo estreitamento de contato com o oriente, especialmente a China. Diários de viajantes passam a ser referência pictórica para o desenho de parques, e os escritos de Confúcio e Lao Tse popularizam uma nova percepção da paisagem onde jardins e parques refletem o papel do homem e da sociedade na natureza, enfatizando a importância dos parques como espaço de contemplação e meditação. Tomando como modelo o jardim chinês, os jardins ingleses passam a incorporar características no traçado de percursos curvos, pontuados por clareiras e pequenos pavilhões que em conjunto com esculturas adquiriam uma carga simbólica e estruturavam

14 Esta breve história dos pavilhões é destrinchada em dois artigos:"The Pavilion, A History of Enduring Transience" de Kersting Busmann e "The Pavilion and the Expanded Possibilities of Architecture" de Berry Begdol ambos extraídos de: SCHAMAL, BETTUM (Org.). The Pavilion, Pleasure and Polemics in Architecture. 2009, p. 12-50. 
o ideal de viagem filosófica proposto por Confúcio. Ao longo do século XVIII passam a agregar também a influência do quiosque turco, proporcionando mais mobilidade aos elementos construídos, relacionados cada vez mais a um descolamento da realidade social e tornando-se um espaço de fuga para o divertimento e frivolidade elitista, que ao longo do século XIX é popularizada de diversas formas como lazer de massas e fuga da realidade industrial.

De um ponto de vista da história da arquitetura moderna, o pavilhão ganha especial interesse a partir das Bienais, associado ao uso de galeria de arte, e das Feiras Mundiais. Nestas ocasiões, concentram o papel de representar identidades nacionais ao materializar e divulgar tanto aspectos culturais como de desenvolvimento tecnológico, e passam, também, a sedimentar conceitos e criar um ambiente para a experimentação e compreensão do limiar moderno, afinal: “...os meios considerados mais adequados para persuadir o público não são as mostras, os livros, os manifestos, mas os próprios edifícios." 15

Estas exibições consolidam-se como importante campo de experimentação formal e tecnológica apresentando as inovações e possibilidades de uma nova arquitetura desde sua primeira edição em caráter internacional, a Exposição Internacional de Londres (1851), onde o monumental Palácio de Cristal, projeto de Joseph Paxton, aliou engenharia a procedimentos industriais de pré-fabricação na execussão de estruturas modulares de ferro recobertas por vidro que resultaram em uma construção inovadora, concluída em tempo extraordinário e com baixo custo, recuperando todos componentes que foram desmontados do Hyde Park, e remontados em outro ponto da cidade. É também no contexto destas exposições que se divulga o revolucionário conceito de habitar moderno, como o pavilhão $L^{\prime}$ Esprit Nouveau de Le Corbusier que gera polêmica ${ }^{16}$ na Exposição de Artes Decorativas e Industriais de Paris, em 1925, ao apresentar em uma construção dividida em dois volumes, uma réplica na escala $1: 1$ da célula individual, máquina de morar, junto a um anexo com volumetria

15 BENEVOLO. 2009, p. 453.

16 O arquiteto comenta em conferência realizada em Buenos Aires, em 1929, o esforço em fazer com que tapumes, que separavam o pavilhão do restante da exposição, fossem removidos, o que demonstra a resistência da aceitação de suas propostas e da arquitetura moderna neste momento do entre guerras. In: CORBUSIER -1887-1965 Precisões, sobre um estado presente da arquitetura e do urbanismo. São Paulo: Cosac Naify, 2004, p.187. 
circular onde um diorama explicava o Plan Voisin, propagandeando as novas possibilidades sociais e territoriais da arquitetura e do urbanismo ${ }^{17}$. Mesmo após a assimilação destes conceitos os pavilhões das exposições internacionais permanecem como plataformas de experimentação arquitetônica e se direcionam cada vez mais no sentido de uma experiência autônoma ${ }^{18}$, o que levou ao surgimento de diversas obras canônicas, consagradas mesmo anos após seu desmonte ${ }^{19}$, ocasionando reconstruções sob a justificativa de serem verdadeiras obras de arte únicas, que sem qualquer uso específico passam a ser exibidos como monumentos arquitetônicos.

Assim, a maleabilidade do termo reflete sua própria história, de tenda militar a quiosque de jardim, de ala anexa a um edifício principal a galeria. Pode-se afirmar, apesar destas transformações de uso, que são reconhecidos por possuírem uma lógica interna própria, com condições de encomenda e concepção que pressupõe uma arquitetura singular, com utilidade questionável e forte carga simbólica. Apresentam apenas um conceito sobre a construção, uma ideia sobre novos programas e usos, ou uma representação prototípica de potenciais construtivos. Não estão apenas relacionados à uma condição de efemeridade, embora esta tenha sido ao longo da história uma das características que sempre os qualificou, favorecendo as experimentações formais, espaciais e estruturais, minando a noção de funcionalismo, uma das características essenciais da arquitetura, o que fez com que se tornasse um tipo de construção na fronteira da disciplina.

17 Para Beatriz Colomina este pavilhão também assume o papel de crítica à própria exibição de Artes Decorativas, focada na produção e consumo de produtos e desconectada das abordagens da arquitetura e do urbanismo moderno. COLOMINA. 2009, p. 64-78.

18 Inúmeros exemplos ilustram esta história onde a arquitetura passa a falar de si própria ao longo das exposições mundiais. Konstantin Melkonikov apresenta internacionalmente pela primeira e rara ocasião, os experimentos da arquitetura russa na Exposição de Artes Decorativas e Industriais de Paris, em 1925. Lucio Costa e Oscar Niemeyer com o pavilhão do Brasil e Alvar Aalto com o pavilhão da Finlândia, exibem para o mundo os desdobramentos da arquitetura moderna nos países fora de seu eixo inicial, na feira de 1939, em Nova Iorque. O Pavilhão Breda de Luciano Baldessari na Feira internacional de Milão, em 1952, apresenta o pavilhão como elemento comercial de identidade coorporativa onde a forma é o elemento publicitário, da mesma forma que Le Corbusier e Xenaxis criam o grande poema eletrônico para Philips, em 1958, unindo arquitetura, música, cinema e tecnologia.

19 O pavilhão de Barcelona, de Mies Van der Rohe é o caso mais conhecido de reconstrução de um pavilhão (1929-1986), mas o mesmo ocorreu ao pavilhão $L^{\prime}$ Esprit Nouveau de Le Corbusier e Pierre Jeanneret que foi reconstruído em Bolonha, na Itália (1925- 1977), e os pavilhões de Sonsbeek Park, de Rietveld e Aldo Van Eyck que foram reconstruídos no museu Kröller-Müller e serão analisados na sequência. 


\subsection{Os Pavilhões de Sonsbeek.}

Partindo do pavilhão, seu uso como galeria, e de seu paralelo com a escultura na ocupação dos jardins do século XVIII, o pavilhão representa uma arquitetura no limiar entre exterior e interior, entre objeto e assunto, tendendo a uma fusão do continente arquitetônico e o conteúdo escultura. Ao se perguntar o que a escultura tem a acrescentar à arquitetura, Penélope Curtis, no livro "Patio and Pavilion, the place of sculpture in modern architeture $^{20}$ ", procura analisar o papel de complementaridade da escultura como elemento autônomo que acrescenta algo que a arquitetura, por si só, não teria sido capaz de articular em termos de arranjo espacial, pontuando justamente as diferenças entre ambas categorias, que trabalhando em conjunto, sob a orientação geral do arquiteto, constituiriam um todo através do qual, à arte, caberia estabelecer um contraponto subjetivo ao racionalismo da arquitetura moderna. Este raciocínio remete à discussão do conceito de "síntese das artes ${ }^{21}$ " moderna, que, consolidado na Bauhaus, reporta-se à gesamtkunstwerk, ou obra de arte total, de Richard Wagner e incuti a ideia de um trabalho coletivo onde a arquitetura promoveria a integração de artistas, numa grande construção social rumo ao novo edifício do futuro.

A inversão no sentido da pergunta formulada por Curtis, passando a agora a indagar de que forma o espaço arquitetônico poderia contribuir para a escultura, resulta na tendência de complementaridade entre pavilhão e escultura, que passam a se diluir numa mesma e única experiência espacial, especialmente a partir da segunda metade século XX.

20 Penelope Curtis é curadora do Instituto Henry Moore, em Leeds, na Inglaterra, e empresta o título de seu livro do trabalho de Alisson e Peter Smithson (1956) apresentado na exposição "This is Tomorrow" na galeria Whitechapel.

21 Sobre este debate ver: FERNANDES, Fernanda. "A Síntese das Artes e a Moderna Arquitetura Brasileira dos Anos 1950" e "Síntese da Artes e Cultura Urbana. Relações entre arte, arquitetura e cidade", para um aprofundamento sobre o desenrolar do tema no contexto dos CIAM. 

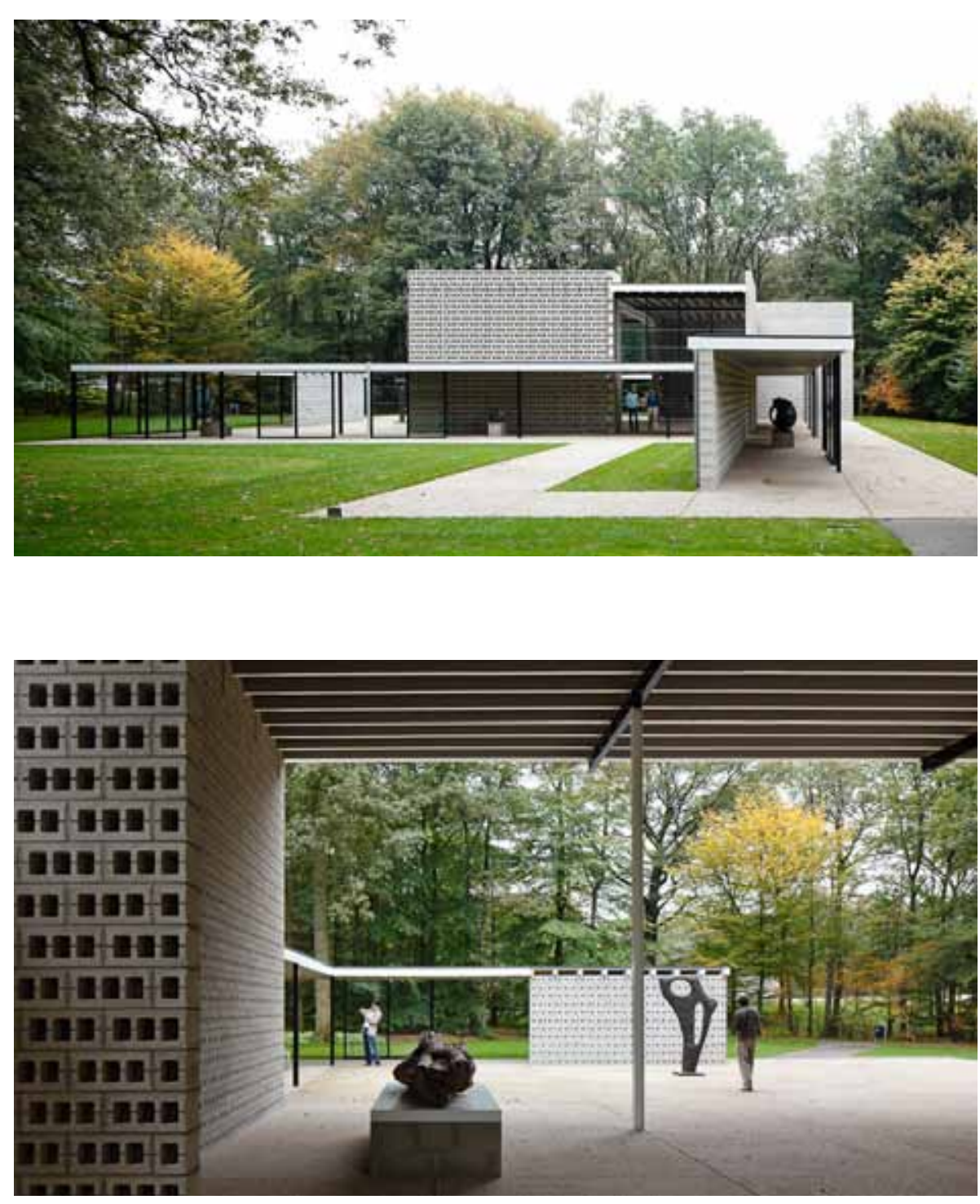

figuras 4 e 5

Gerrit Rietveld. Pavilhão de esculturas para Sonsbeek Park -1955

(reconstruído em 1965 no Kröller-Müller Museum, Otterlo, Holanda) 
No segundo pós-guerra surgem programas que promovem a construção de pavilhões de esculturas em parques como o Battersea, em Londres, e Sonsbeek, em Arnheim, Holanda. O objetivo era democratizar a arte retirando peças de museus para torná-las mais acessíveis, exibindo-as ao ar livre. No entanto, fazia-se necessário uma construção que pudesse servir de moldura e pano de fundo para que as peças mais delicadas não se perdessem na paisagem, ou mesmo, para que proporcionassem uma relação de escala.

Gerrit Rietveld projeta, em 1955, um pavilhão para Sonsbeek ( figuras 4 e 5) que começa a por em xeque a relação de moldura espacial que restringe a arquitetura ao papel de mediadora que proporciona uma correta apreensão da obra. A seleção de obras daquela edição favorecia um conjunto de esculturas figurativas reunindo artistas de importância histórica como Rodin e Degas a uma produção recente como a de Henry Moore e Brancusi. Para responder a esta equação, que demandava uma estreita relação entre o espaço arquitetônico e as esculturas que abrigaria, mantendo uma interação entre paisagem e construção, Rietveld elabora uma sucessão de planos verticais com diferentes superfícies que configuram variados panos de fundo: transparentes de vidro ou de bloco de concreto liso e bloco de concreto vazado, este último rompendo com a ideia de neutralidade esperada de uma galeria sem prejudicar a leitura da obra. Sobre estes panos verticais, coberturas em diferentes níveis configuravam espaços variados, abertos e unificados por um pátio.

\section{Segundo Curtis:}

"Um pavilhão como este de Rietveld é construído porque sem ele a escultura era insuficiente. O pavilhão cria uma razão para o deslocamento para um parque, mas é duvidoso que faça a escultura parecer melhor ou mais interessante do que o seria no museu. Neste caso, o pavilhão quase supera sua encomenda, sugerindo que seja pelo menos tão interessante quanto o trabalho lá dentro, se não mais.”22

Desmontado assim que termina a exibição, todo o material

22 "A pavilion such as Rietveld's is built because without it the sculpture was insufficient.. The pavilion gives it a reason for being transported to a park, but it is doubtful whether it makes the sculpture look any better or more interesting than it would in the museum. In this case, the pavilion almost outstrips its brief, in suggesting itself at least as interesting as the work inside, if not more so." CURTIS. 2008, p. 122. 
utilizado é reciclado segundo instruções do arquiteto, mas, em 1963, Rietveld é convidado a reconstruir o pavilhão de Sonsbeek, agora no contexto de um museu, o Kröller-Müller ${ }^{23}$ na Holanda. Com uma quantidade menor de obras, todas da artista inglesa Laura Hepworth, o pavilhão ganha com a nova implantação mais aberta e conectada com o parque, e passa de moldura espacial temporária destinada a uma exposição de esculturas ao status de monumento e espécie de tributo ao arquiteto.

Trajetória semelhante é desempenhada pelo pavilhão de esculturas proposto por Aldo Van Eyck (figuras 6,7 e 8), que dez anos depois ocupa a mesma implantação em Sonsbeek, agora para abrigar uma coleção de esculturas com um recorte predominante de obras abstratas e surrealistas ${ }^{24}$ que em seu conjunto geravam certo incômodo, característico à arte surrealista, com diferentes texturas e formas monolíticas de escala próxima à humana que, no entanto, demandavam ser assentadas sobre bases.

Van Eyck salienta que a grande qualidade e razão de sucesso do pavilhão de Rietved seria a perfeita articulação entre parque, pavilhão e público, embora não concordasse com a premissa de se deslocar uma coleção de esculturas para que, em contato com a natureza, pudesse ganhar maior destaque ou novas interpretações. O arquiteto compunha o Team $X$, grupo internacional que focava - naquele momento de revisão das premissas modernas, especialmente aquelas relacionadas ao urbanismo - na possibilidade de construção de cidades pautadas em relações mais inclusivas e humanizadas, ao pregar a substituição do binômio moderno espaço-tempo pelo sentido de lugar-ocasião. Tal relação poderia ser conquistada, segundo Van Eyck, articulando macro e micro escalas, conceito transposto para sua conhecida proposição: "A casa é uma cidade e a cidade é uma casa - a cidade não é uma cidade a menos que seja também uma enorme casa- a casa é uma casa apenas quando também é uma pequena cidade." 25

Assim, focando num ambiente que refletisse o ser humano e suas

23 O Museu Kröller Muller está localizado em um parque nacional holandês, o De Hoge Veluwe, em Otterlo, e desde 1938 exibe uma coleção privada de arte moderna e contemporânea iniciada por um casal de colecionadores em 1907. O museu possui um extenso jardim de esculturas e reconstruiu os pavilhões de Sonsbeek, tanto o de Rietveld quanto de Aldo Van Eyck, numa perfeita interação entre escultura, arquitetura e natureza.

24 Dos seguintes artistas: Arp, Brancusi, Pevsner, Gaudrier Brzeska, Gozáles, Hepworth, Giacometti, Richier, Ernst, Matta, Noguchi, Tajiri, Caro, Turnbull, Constant, Wouters, Pomodoro e Paolozzi.

25 "House is city and city is house - a city is not a city unless it is also a huge house - a house is a house only if it is also a tiny city." VAN EYCK apud LIGTELIJN, 1999, p. 49. 
identidades, o Team $X$ buscava dialogar com uma nova visão cultural, até então melhor expressa por outros campos disciplinares, como acreditava Van Eyck que criticava duramente o Congresso Internacional de Arquitetura Moderna (CIAM) ${ }^{26}$ tanto pela persistência em negligenciar relações entre homem e ambiente construído ${ }^{27}$ e evitar os debates sobre uma cidade ante os reflexos da produção em massa, quanto a respeito da noção de síntese das artes entendia como possibilidade da adesão mais transgressora entre artistas e arquitetos. Van Eyck acreditava que"a cooperação é possível e talvez desejável. Síntese e integração certamente não são desejáveis. Integração significa impotência." 28

Ao debater as preocupações programáticas e as relações de causa e efeito entre programa e tipo como estimuladores da dualidade forma-função, que teria destinado aos arquitetos o papel de meros solucionadores de problemas, Van Eyck e o Team X contribuem para um alargamento do debate arquitetônico em curso nos anos 60 , e materializa estas questões com grande potência no pavilhão para Sonsbeek.

O projeto parte de um elemento, o bloco de concreto liso que é utilizado em toda sua potencialidade construtiva tanto nas bases das esculturas, quanto na elevação de seis paredes paralelas, que configuram os cinco corredores interrompidos, em algumas ocasiões, para possibilitar a passagem entre eles. Por vezes, estas mesmas paredes se expandem na forma de uma semicircunferência, gerando, de um lado um recinto côncavo, e de outro um estreitamento da passagem, diluindo as obras ao longo deste jogo de esconde-esconde ${ }^{29}$, ver e ser visto, próprio dos labirintos.

Segundo Herman Hertzberger ${ }^{30}$, esta seria mais uma aproximação de extremos contraditórios comuns ao arquiteto. A organização inerente

26 Em 1959, após a renúncia de todos os participantes do Team X, o XI CIAM realizado dentro do museu Kröller-Müller, encerrou definitivamente as atividades dos CIAMs. O grupo já havia participado das discussões em curso desde o VIII CIAM em 1951 onde se intensificava o enfoque voltado para os problemas urbanos. Nessa ocasião o conceito de síntese das artes fora expandido para um diálogo entre arte, arquitetura e vida urbana, sendo importante elemento na ocupação do coração da cidade adotando caráter de monumento.

27 Van Eyck colaborou com o grupo Cobra e segundo Curtis possua sua própria interpretação do que poderia significar a síntese das artes na medida em que cada vez mais se aproximava do território artístico em seu trabalho. In: CURTIS. Op cit., p.132.

28 "Cooperation is possible and perhaps desirable. Synthesis and integration are certainly not desirable. Integration means impotence." VAN EYCK apud CURTIS. Op. cit., p.130.

29 O Arquiteto inicia sua carreira projetando playgrounds para a cidade de Amsterdã.

30 No texto: "The Mechanism of the Twentieth Century and the architecture of Aldo Van Eyck.” HERTZBERGER apud LIGTELIJN, 1999, p.22-25. 

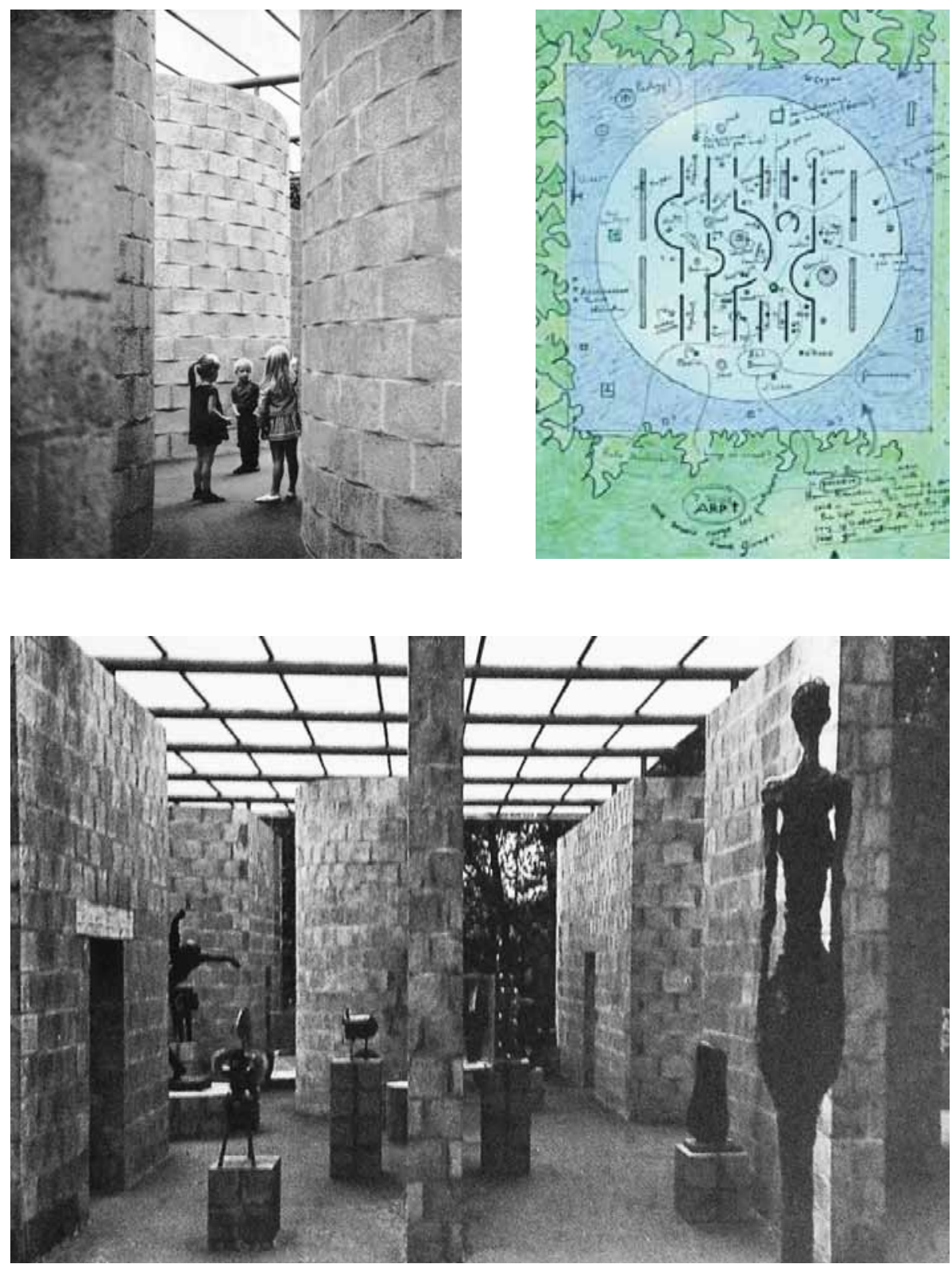

figuras 6,7 e 8

Aldo Van Eyck - Pavilhão de esculturas para Sonsbeek Park - 1965

(reconstruído em 2006 no Kröller-Müller Museum, Otterlo, Holanda) 
ao labirinto é tornada clara pelas duas formas geométricas puras, o quadrado representado pela cobertura translúcida pousada sobre as paredes, circunscrita à delimitação do piso, operando na dicotomia entre a "clareza" formal do pavilhão e a noção de labirinto numa organização espacial que diluía a tendência de centralidade das formas adotadas. A unidade proporcionada pelo material utilizado, também como solução para o desenho de bancos e das bases para as esculturas, ressaltava as qualidades de escala e proporção do pavilhão que, acomodado sobre uma diferenciação de piso de forma circular, assemelham-se ao procedimento do artista minimalista Carl Andre, que utilizando um único material industrializado em cada obra, propunha uma série de arranjos que alteravam o comportamento do espectador em relação ao espaço, revelando assim o entorno, a galeria. (figura 9)

Assim, se a escultura minimalista estava criando seu próprio ambiente, ao propor a "escultura como lugar" e despertar a consciência do espectador em relação ao espaço, neste caso a neutralidade material da galeria que em sua literalidade fazia parte da obra, Van Eyck realizava operação semelhante porem inversa, ao distanciar-se do papel de mediador para uma exposição no interior de seu projeto $^{31}$ e colocar o espectador em foco, transformando sujeito em escultura, assim como o pavilhão. "As obras podem ter adicionado uma nota de inquietação, como objetos à espera de que algo aconteça, mas parecem deslocados. Ou Van Eyck perdeu a fé na escultura, ou a sua arquitetura revela o fato de que a escultura perdeu a fé em si mesma" 32

Com a análise deste pavilhão condensa-se a intenção teórica de se explicitar a tendência de convergência entre arte e arquitetura através do pavilhão, pois no momento em que o espectador se relaciona de forma mais ativa com o edifício, segundo Curtis, está proposta uma revisão no conceito de síntese das artes não somente pelo viés de uma colaboração entre a produção dos artistas e arquitetos, mas principalmente pela relação participativa do público com o espaço.

31 Isso não significa que Van Eyck tenha negligenciado a exposição de esculturas, pelo contrário, desde seus primeiros croquis é possível ver a preocupação com cada obra e seu posicionamento em relação à arquitetura, conforme demonstrado na figura 7 .

32 "The works may have added a note of disquietude, like objects waiting for something to happen, but seem displaced. Either Van Eyck has lost faith in sculpture, or his architecture betrays the fact that sculpture has lost faith in itself." CURTIS. Op. cit., p.130. 


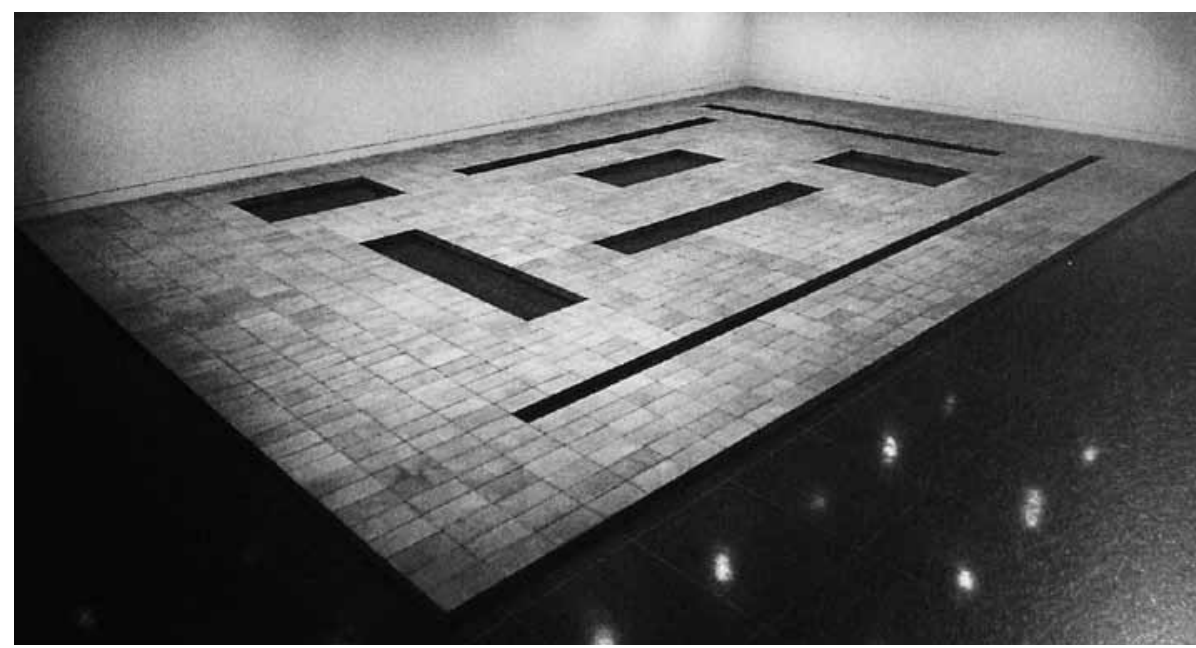

\section{figura 9}

Carl Andre, 8 Cuts, 1967

(Instalation View, Dwan Gallery, Los Angeles) 


\title{
1.4 O espaço de exibição como exibição do espaço.
}

\author{
"O espaço não é simplesmente a projeção \\ tridimensional de uma representação mental, \\ mas é algo que se ouve e no qual se age.",33
}

A produção tridimensional que surge no contexto norteamericano dos anos 60 inicia o processo de deslocamento da experiência estética da arte para o lugar. Assim a experiência não mais se encerraria numa mediação apenas entre obra e espectador e sim na fruição do espaço, sugerindo a diluição de limites entre arte e arquitetura assim como entre interior e exterior de museus e galerias que passam a ser criticados como instituições inseridas num sistema de cultura de massa responsável pela comodificação das obras.

A arte minimalista e a land-art iniciam este processo de mudança de um ponto de vista que "diferencia o espaço de exposição, ao de exposição do espaço"34. Como afirma Michael Heizer em 1970 numa discussão com Denis Oppenheim e Robert Smithson, no texto considerando fundamental para a land-art: "O trabalho não é posto no lugar, ele é esse lugar"35

Ao incorporarem as condições físicas de um lugar específico como parte integrante e essencial para realização e mediação do trabalho artístico, a presença corporal substitui a visualidade autônoma, e passa a definir uma produção reportada ao termo sitespecific. Inicialmente relacionado à experimentação fenomenológica dos atributos físicos do lugar, as obras site-specific passam a entrelaçar

33 TSCHUMI, Bernard. Arquitetura e Limites II (1981). In: NESBITT. 2008 p. 181.

34 Beatriz Colomina em conferência proferida no encontro: "O Museu do Agora: Arte Contemporânea, Histórias de Curadoria, Modelos Alternativos”(2011) usa esta expressão para estabelecer um paralelo entre a produção artística dos anos 60 e 70 e grande parte das exposições de arquitetura que desde o período moderno já se preocupavam com a disposição espacial como chave do problema da exposição da arquitetura. Vídeo disponível em:

$<$ http://www.forumpermanente.org/.event_pres/simp_sem/conferencia-internacionalthe-now-museum/> consultado em 28/01/2013.

35 In: FERREIRA-COTRIM (org.). 2006, p.275. 
relações espaciais com camadas ideológicas, constituindo uma arena para debates de processos sociais, econômicos e políticos onde a arquitetura passa a ser confrontada criticamente pela produção artística. $\mathrm{O}$ aspecto da transitoriedade amplia a noção de que, estas obras, para além da relação fenomenológica com o lugar, proporcionam uma abertura para o discursivo e o histórico, ou para o social, o que contribui também para manter estes trabalhos inseridos dentro de um sistema globalizado da arte, no qual os artistas passam a atuar como provedores de serviços artísticos ${ }^{36}$, oferecendo uma experiência única e sem reprodução, onde o tempo de decantação da obra não está ligado somente ao seu tempo de duração. Neste processo, estabelecem um curioso paralelo, pois, partindo da evanescência programada do trabalho, estas obras aproximam-se dos procedimentos arquitetônicos não somente pela escala de suas ações e envolvimento com demandas sociais, mas também porque todo material de suporte à sua concepção - croquis, projetos e maquetes -, processos e registros passam a ser valorizados. Assim, o termo site-specific é assimilado de forma irrestrita por artistas, arquitetos e instituições, sendo diretamente relacionado à potência de um discurso crítico, que, segundo Miwon Kwon, passa a ser utilizado como cultura dominante, e institucionalizar e enfraquecer uma prática pelas mesmas forças do mercado ao qual inicialmente se opuseram ${ }^{37}$.

A valorização de itens processuais, desvalorizados até então, é destacada por Beatriz Colomina como um fenômeno em curso ao longo da década de $80^{38}$, quando se consolidam as exposições de arquitetura, onde desenhos arquitetônicos e projetos passam a ser comercializados, e, em alguns casos, funcionam como especulação teórica e crítica totalmente desvinculada de sua real possibilidade de execução. Neste processo nota-se um curto-circuito onde, por um lado, artistas buscavam o rompimento com a estrutura institucional e,

36 Miwon Kwon desenvolve este tema, da não subordinação da obra ao lugar, no segundo capítulo do livro "One place after another, site-specific art and locational identity." 2004, p.33-55.

37 KWON, Op. cit., p.8.

38 Conferência proferida no Now Museum disponível no site Fórum Permanente: <http://www.forumpermanente.org/.event_pres/simp_sem/conferencia-internacional-thenow-museum/ >consultado em 20/06/2012. 
em contra partida, arquitetos se aproximavam de galerias para exporem seus desenhos revelando uma nova geração de arquitetos e artistas que interagiam e circularam por diversas galerias em Nova Iorque, a exemplo de Dan Graham, Peter Cook, Steven Hall, Peter Eisenman e Diller \& Scofidio, entre outros.

Nesta esfera de debates onde arte e arquitetura encontramse enredadas, a própria noção de "campo ampliado" parece ter se esgarçado, revelando-se uma potente resposta a um sintoma que começava então a se apresentar, mas que, nas últimas décadas, vem se intensificando e encontra desdobramentos na crítica de diversos autores, como Hal Foster, que recentemente tratou do assunto como "complexo arte-arquitetura", pois, em meio ao atual contexto de uma economia cultural global, nem sempre esta aproximação pode ser vista como positiva, segundo o autor ${ }^{39}$ - o que explica o uso do termo “complexo" no sentido de um diagnóstico clínico ou de uma síndrome.

A perspectiva de que o espaço é o elemento que proporciona esta diluição disciplinar, especialmente o espaço da metrópole contemporânea, serve como ponto de partida tanto para Anthony Vidler - que lida com uma assimilação psicológica da realidade para definir uma produção que considera ser uma "arte intermediária"40, quanto para Jane Rendell - que elabora o conceito de "prática espacial crítica", relacionado às possibilidades de uma autonomia artística necessária a uma postura crítica - na medida em que ambos encontram no trabalho do sociólogo marxista francês, Henry Lefebvre, uma chave para o entendimento de que o processo de industrialização e urbanização moderno precipitou uma transição em relação à produção de coisas no espaço para uma produção do próprio espaço. Assim, três tipos de relação espacial são postulados por Lefebvre - "prática espacial", a produção e reprodução do espaço e sua relação com a sociedade; "representações do espaço" ou espaço conceituado, aquele dos planejadores, urbanistas e tecnocratas; e "espaço representacional", ou aquele diretamente vivenciado, onde questões simbólicas e físicas são sobrepostas e assimiladas.

39 FOSTER, 2011, p VII.

40 VIDLER, 2001, p.11 
Enquanto Vidler se dedica ao espaço representacional onde as novas mídias são entendidas como decisivas para uma nova ordem espacial ${ }^{41}$, Rendell envereda pela primeira hipótese, a da prática espacial como ponto de contato entre trabalhos site-specific - especialmente aqueles que invadem o espaço público com suas intervenções na escala urbana - e obras de arquitetura que se aproximam mais de questões conceituais. Rendell elabora uma teoria interdisciplinar do espaço na cidade contemporânea, atentando para a importância de se diferenciar os monumentos, que se relacionam com o contexto de forma a pacificar o olhar para o entorno onde estão inseridos, das práticas que estabeleçam relações com seu entorno de forma a tencioná-lo por seu conteúdo crítico. Com isso, embora a arquitetura relacione-se com sua implantação e com as características específicas do lugar, está também condicionada a circunstâncias de encomenda e orçamento, programa e legislação, e uma série de interesses que norteiam o desenvolvimento do projeto, o que leva a autora a propor uma inversão na usual demanda envolvida nas contratações de projetos arquitetônicos e perguntar: "Onde estão os lugares que os arquitetos devem investigar e inventar para criticar os sistemas dentro dos quais eles operam?" 42

As exposições de arquitetura colocam-se como uma das possíveis respostas à pergunta de Rendell e não se limitam apenas ao que pode ser reconhecido como "paper architecture ${ }^{43}$ ", no sentido de uma aproximação com o procedimento de deslocar a ação para a documentação discursiva como no "non-site" de Robert Simthson ${ }^{44}$.

O espaço de exposição como exposição do espaço reflete, no plano museológico, a transição moderna da produção de coisas

\footnotetext{
41 Segundo Vidler, as novas mídias aproximam os atuais projetos de escritórios como Coop Himemblau, Eric Owen Moss e Daniel Libeskind aos primeiros experimentos das vanguardas artísticas, desestabilizando a noção cartesiana, só que agora, numa premissa pósdigital que possibilita enfoques pouco explorados pela crítica e a história da arquitetura, como a aproximação com questões de gênero ou biologia.

42 "Where are the sites architects must investigate and invent for critiquing the systems within which they operate?" RENDELL.2006, p. 37.

43 Em livre tradução "arquitetura no papel”, que neste contexto diz respeito a toda arquitetura que não se dá efetivamente como construção e permanece numa camada discursiva ligada à ideia do projeto e da escrita.

44 Para o artista o local de realização do trabalho era considerado o "site" e o local de documentação do trabalho o "non-site".
} 
no espaço para a produção do próprio espaço fundamentada por Lefebvre, e impulsiona o museu contemporâneo, consciente desta relação, a transformar-se e direcionar-se como um veículo para fruição do trabalho expandindo sua arquitetura como presença marcante e estimuladora de obras que intensificam a experiência, antes temporal e histórica - diacrônica - para uma experiência contemporânea sincrônica ${ }^{45}$, de intensa relação com o local.

Com isso ampliam-se as escalas dos espaços expositivos assim como a escala das obras que os ocupam, que não mais se apresentam como forma autônoma, mas como interface capaz de despertar e envolver o espectador neste lugar único. Sob este aspecto, Hall Foster afirma que: "alguns destes edifícios são tão esculturais ou performativos, que os artistas podem acreditar que chegaram atrasados para festa, colaboradores depois do fato consumado." ${ }^{46}$

Programas como o "Monumenta", que ocupa o Grand Palais, em Paris, ou a Unilever Series na Turbine Hall da Tate Modern, em Londres, são exemplos de programas voltados para ocupação de grandes espaços onde a arquitetura se impõe aos projetos artísticos, fazendo com que os artistas responam à grande escala destes espaços. Da mesma forma instituições como o DIA Art Foundation, que já havia financiado o “Lightning Field”(1977) de Walter de Maria e o complexo de Marfa (1979), de Donald Judd, acabam por ampliar suas instalações e, em 2003, inaugura uma nova unidade, o DIA Beacon, instalada numa antiga fábrica de 28 mil metros quadrados para abrigar uma coleção de obras permanentes de grande escala produzidas a partir dos anos 60, que segundo Hall Foster, representa um dos casos mais significativos do que ele qualifica como "complexo arte-arquitetura ${ }^{47}$ ".

Os pavilhões surgem como mais um elemento nesta equação,

45 Segundo Rosalind Krauss, no texto "The Logic of the Late Capitalist Museum" de 1990, o museu contemporâneo abandona sua natureza enciclopédica de acúmulo de camadas temporais selecionadas numa visão particular da história da arte - diacrônicas - para tornarem-se sincrônicos, focados na intensidade acumulativa de uma experiência. p.431.

46 "Some of these buildings are so performative or sculptural, that artists might feel late to the party, collaborators after the fact." FOSTER. Op. cit., p. XI.

47 Hal Foster dedica o sétimo capítulo: "Minimalist Museums" à uma análise do DIA Beacon, à ampliação do MOMA de Nova Iorque e ao projeto da nova ala da Tate Modern em seu livro "The Art Architecture Complex." Ibidem, p. 104-129. 
tanto dentro do espaço museológico, nos museus de grande porte que possibilitam obras que articulam arquiteturas dentro da arquitetura existente como em novos modelos de museus-jardins, com construções dispersas na paisagem. O pavilhão surge também como resposta estratégica de instituições que realizam programas de construções temporárias na tentativa de uma expansão de seu território buscando abarcar obras que diluam os limites do museu com o espaço urbano, ou ainda, como reflexo de um interesse em se inserir a arquitetura na agenda de debates culturais, impulsionada pela grande relevância da arquitetura na construção da realidade urbana e, talvez justamente por isso, o pavilhão surja como campo de afrontamento crítico da condição contemporânea, ou como uma heterotopia ${ }^{48}$, na medida em que estabelecem uma relação análoga de espelhamento, e operam como espaços onde as utopias podem ser realizadas, representadas ou mesmo invertidas e assim se tornar um repositor de utopias e possibilidades.

48 Ideia desenvolvida por Foucault na conferência "De Outros Espaços", realizada em 14 de Março de 1967 no Cercle d'Études Architecturales. In: Michel Foucaul Aesthetics, the essential works 2. 1998, p. 175-185. 


\section{Da arte para arquitetura, da arquitetura para arte.}

\subsection{Limites arquitetônicos.}

Refletir sobre o "campo ampliado" e seus desdobramentos, no sentido de compreender uma produção contemporânea que tende para uma linha de convergência entre arte e arquitetura, significa retomar as próprias definições da arquitetura que possibilitam definir seus limites disciplinares. Voltar-se para a demarcação das especificidades de campos de atuação contribui para revelar paradoxos e contradições da própria definição da arquitetura, percebida nas suas obras de limite.

Bernard Tschumi, no início da década de 80 , escreve uma sequência de textos para a revista Artforum com o título "Arquitetura e Limites" 49 , nos quais percorre este caminho e investiga as bases da disciplina como possibilidade de transgredi-las e promover uma crítica necessária. Os limites são, portanto, tratados como uma área estratégica da arquitetura, não como "elementos dispensáveis, um luxo no campo do conhecimento" ${ }^{50}$, mas como estímulo essencial para um debate sobre a produção arquitetônica levando-se em conta suas diversas expressões - textos, eventos ou desenhos -, todas fronteiras da construção socialmente justificável, reafirmando que a arquitetura não se resume ao processo de construção, mas inclui todas expressões que, para além da construção, informam sobre o pensamento, as preocupações e os edifícios de seu tempo. Este raciocínio encontra no pavilhão também um par, pois como afirma Tschumi:"por certo não se exclui o domínio do construído, posto que pequenas obras de natureza experimental, muitas vezes viriam a cumprir um papel semelhante." ${ }^{21}$

49 "Arquitetura e Limites I, II e III" foram reunidos e comentados por Kate Nesbitt em "Uma Nova Agenda para a Arquitetura". Op. cit., p.172-188.

50 Ibidem, p.176.

51 Ibidem, p.174. 
Se definições e limites são próprios de cada época, Tschumi encontra na "tríade vitruviana" o enunciado que persiste através dos tempos como essência da definição de arquitetura, mas propõe que ao longo do século XX, com a expansão da industrialização tenha ocorrido uma ruptura desta noção. A venustas, ou beleza, fora substituída no vocabulário dos arquitetos pela linguística estrutural. A firmitas também perdera sua importância na medida em que "o interesse moderno pela superfície privou ainda mais os volumes de sua substância material ${ }^{152}$ pois, uma vez desvinculada a estrutura da vedação, seria possível uma recomposição dos volumes por leis formais e não estruturais. A utilitas, que se refere à noção de comodidade, e está diretamente relacionada à origem utilitária da arquitetura como produto da necessidade de abrigo, fundamentada na proporção do corpo humano, restaria o legado de "único juiz competente" ${ }^{53} \mathrm{da}$ disciplina arquitetônica, na medida em que a passagem do espaço do corpo para o "corpo no espaço" possibilitaria um deslizamento da noção de programa - a lista de requisitos utilitários orientadores do projeto - no sentido de uma ruptura com a máxima "forma segue função", pois, com a intromissão dos eventos nos espaços arquitetônicos, seria possível provocar uma disjunção entre conteúdo e forma, esvaziando a arquitetura de implicações morais e funcionalistas ${ }^{54}$. Assim, segundo Tschumi, "Se o ato de construir tem uma relação com a utilidade, a arquitetura não o tem, necessariamente."55

Ao questionar a utilidade da arquitetura como uma das essências disciplinares, e entender o funcionalismo como uma imposição moral, Tschumi procura reconceder aos arquitetos uma função crítica relacionada à formulação de problemas como possibilidade essencial de negação do papel de mero solucionador de programas pré-estabelecidos, uma vez que estes sempre estiveram relacionados à reprodução de valores culturais e sociais, ou seja, não apenas a uma noção descritiva e quantitativa de um projeto, mas a todo discurso ideológico implicado na sua efetivação.

\footnotetext{
52 Ibidem, p. 180

53 Idem.

54 Ibidem, p.181.

55 Ibidem, p.176.
} 
O deslizamento de uma ideia de programa, visto como elemento desafiador dos limites disciplinares, baseado em conceitos mais abrangentes e de grande potência crítica, é para Anhtony Vidler uma das possibilidades de revisão da produção arquitetônica, no sentido de um "campo ampliado", assunto desdobrado no artigo "Toward a Theory of the Architectural Program" e publicado na revista October, em 2003. Escritórios como Diller Scofidio+Renfro, SANAA e OMA, entre outros, seriam exemplos contemporâneos de uma redefinição do uso do programa na forma de diagramas expressos iconograficamente na arquitetura, conduzindo a um resgate necessário dos escritos de Reynar Banham - que focavam na produção inventiva do Grupo Archigram, nos anos 60 -, e do historiador da arquitetura britânico, John Summerson.

Para Summerson, programa é "a descrição de dimensões espaciais, relações espaciais e outras condições físicas requeridas para o desempenho de funções específicas, ${ }^{56}$ que envolvem um processo temporal de repetição e sedimentação de padrões, não sendo estáticos como fazia parecer a tradição clássica e sua ingênua tradução formal de uma ideia programática. No entanto, para o autor, uma teoria que colocasse o programa como princípio poderia presumir mera retórica intelectual. Banham, ao contrário, via na investigação do programa uma alternativa a novas teorias que surgiam naquele momento e que, na busca por novos caminhos para a arquitetura desembocavam em experimentos práticos com resultados puramente formais. Sua confiança era depositada na tecnologia, não de maneira fetichista, mas prenunciando novos horizontes, especialmente no que dizia respeito a uma nova estética, como no projeto "Fun Palace" (1961), de Cedric Price, aberto à transformação pela participação efetiva do usuário na acoplagem de peças pré-fabricadas que geravam uma "zona de total possibilidade" 57 , ou pelos projetos do Archigram "Plug-in-City", "Computer-City" e "Undewater-city", todos de 1964, que segundo Vidler, lançaram a mais fundamental crítica ao tradicional programa arquitetônico por assumirem temas como o descartável, o consumo de massas, o nomadismo, a diversão e o conforto material e psicológico.

56 SUMMERSON. Apud VIDLER. 2003, p.66.

57 VIDLER. Op. cit., p.66. 


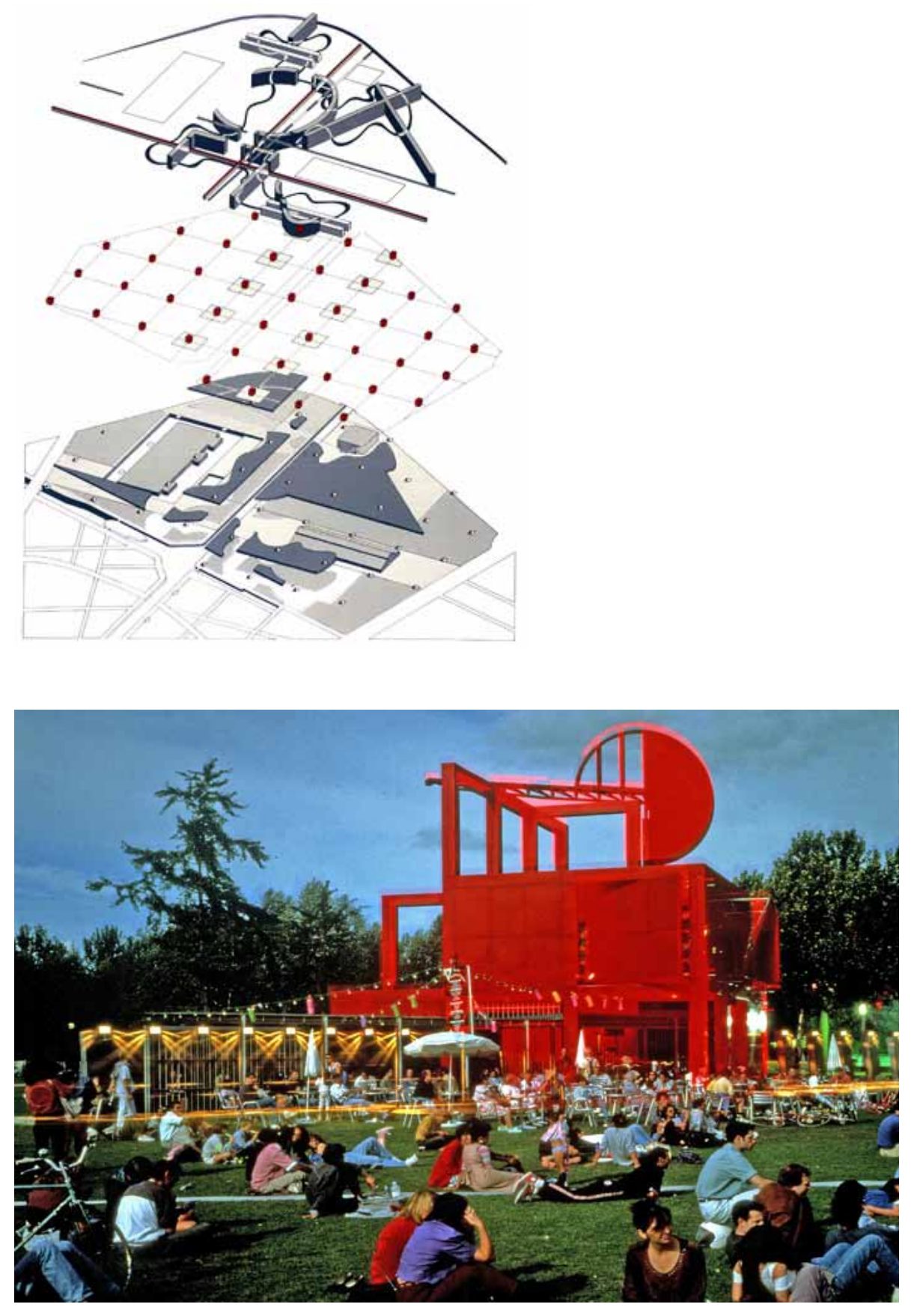

figuras 10 e 11

Bernard Tschumi. Projeto do parque La Villete e Follie 1982-1998

(Paris, França) 
O grande apelo visual das imagens geradas pelo Archigram não pode ser interpretado de maneira superficial, pois elas instigam uma relação sensorial com o edifício e evidenciam a carga conceitual das propostas, descolando-as da relação formal e dos padrões estéticos préestabelecidos. A potencial nova abordagem do programa pode, portanto, gerar uma arquitetura que não é nem formalmente autônoma, nem tem sua forma determinada por sua função.

Nesta mediação entre função e forma, programa e evento, arquitetura ou construção, os pavilhões colocam-se como enclave. Possuem programa simplificado como elemento potencialmente aberto ao evento, ou como um espaço que se deixa vestir e modificar por diversos usos, assim como as follies propostas por Tschumi para o parque La Villete, projeto no qual o arquiteto aplica suas discussões teóricas. O parque surge como resultado de uma metodologia proposta para regular o projeto, em oposição a um programa urbanístico, e, através de uma "sobreimposição" 58 (figura 10) de camadas históricas do bairro a outras camadas desvinculadas do local, atinge assim, um resultado para além do programa onde os procedimentos projetuais operam como reguladores que conduzem ao resultado, ou seja, o programa é entendido como uma estrutura conceitual. Cada camada sobreposta interrompe e interfere na outra, de forma a se obter um grid sobreposto por linhas, superfícies e pontos referenciais, assim como na teoria de Kandisnky.

As follies estabelecem os trinta e cinco pontos referenciais, sempre distanciados em cem metros, e nomeados por uma letra e número, como uma coordenada espacial, o que de fato são, pois orientam os percursos e enfatizam o movimento na grande extensão do parque. Construídos em concreto e aço pintado de vermelho, cada uma com um desenho único originado da intersecção de espaços, movimentos e eventos aplicados a um cubo de dez por dez metros de aresta (figura 11), esses pavilhões colocam-se como edifícios sem qualquer função pré-estabelecida, de forma que possam ser assimilados pelo público e utilizados de maneira flexível para desempenhar

58 TSCHUMI. Op. cit., p. 189. 
múltiplas atividades, não apenas aquelas pré-definidas por um programa de necessidades. Desta forma, as follies se abrem para o acaso, ou para a loucura - uma das traduções do termo francês - sendo recente a ocupação de algumas delas por atividades pré-estabelecidas, como escritórios ou cafés.

Tschumi recupera esta que é uma das origens históricas do pavilhão, as follies de jardim do século XVIII, frívolas e desvinculadas de qualquer necessidade funcional para associá-las aos jardins que servem ao deleite e ao "prazer sensual do espaço" ${ }^{59}$, e assim subverter o axioma arquitetônico da utilidade como processo de resgate de sua força política, colocando que:

"Mais uma vez, se nos últimos tempos há motivos para duvidar da necessidade da arquitetura, então a necessidade da arquitetura pode muito bem estar em sua desnecessidade... O consumo inteiramente gratuito da arquitetura é, paradoxalmente, político, na medida em que perturba as estruturas estabelecidas." 60

O abandono do dualismo forma e função, destacado porVidler como uma condição atávica a ser superada pelo "campo ampliado arquitetônico" ${ }^{61}$, estabelece uma aproximação de limites entre arte e arquitetura que não se dá apenas pela negação da funcionalidade num caminho de liberdade formal tendendo ao escultural. Significa também, um entendimento de que obras de limite, como o pavilhão, possibilitam especulações e novas interpretações conceituais estimuladas por um programa arquitetônico de importância rebaixada e, assim como as exposições de arquitetura, apresentam-se como o reflexo de uma produção multifacetada da arquitetura, entendida não apenas como construção, mas como polarizadora de experimentação e veiculação de discursos no sentido do que Felicity Scott encara como plataforma operacional.

59 Ibidem. p. 577.

60 Ibidem. p.578.

61 VIDLER. 2004, p.147. 


\subsection{Plataformas operacionais}

"[A]rquitetura não é edifício. Edifícios são objetos e o ato de construir conduz a tal objeto, mas arquitetura é outra coisa.É a maneira como pensamos e falamos sobre edifícios, como os representamos e construímos." ${ }^{2}$

Nas recentes bienais de Arquitetura o termo "instalação" passou a ser corriqueiramente aplicado às exposições e, o tradicional trinômio da representação arquitetônica - projeções ortogonais, perspectivas e maquetes - cedeu gradualmente espaço para construções dentro de construções, obras conceituais, performances e alegorias em sintonia com os grandes eixos estabelecidos pela figura do curador, que antes restrito ao universo artístico passa agora a fazer parte também do universo arquitetônico.

Se o espaço, como meio, foi capaz de diluir os limites disciplinares entre arte e arquitetura, da mesma maneira o espaço passa a ser o objeto das exposições de arquitetura onde os arquitetos, lançando mão de recursos próprios aos artistas, a cada nova exposição ou Bienal de Arquitetura, revelam novas experimentações no sentido de uma produção intersticial.

Desde que a arquitetura entrou na programação de Instituições dedicadas à arte moderna ${ }^{63}$, tanto como acervo, quanto nos seus calendários de exibições temporárias - reconhecidamente a exposição "Modern Architecture: International Exhibition" de 1932, com curadoria de Philip Johnson no MOMA de Nova Iorque, quando maquetes

62 Aaron Betsky foi o curador da $11^{\circ}$ Bienal internacional de arquitetura de Veneza em 2008. É dele a frase utilizada como epígrafe: "[A]rchitecture is not building. Buildings are objects and the act of building leads to such objects, but architecture is something else. It is the way we think and talk about buildings, how we represent them, how we build them." BETSKY apud ABERCOBIE. 2009, p.404.

In: 11 Mostra Internazionale di Architettura. Review by: Stanley Abercrombie - Journal of the Society of Architectural Historians, Vol. 68, No. 3 (Septembro 2009), p. 404.

63 Segundo Jean Luis Cohen as exposições de arquitetura existiram desde o século 19, como meio de transformação da cultura arquitetônica a exemplo dos futuristas em Milão em 1914, os expressionistas em Berlim em 1919 e os construtivistas em Moscou, em 1921, mas não como programa específico dentro de museus e instituições artísticas. 


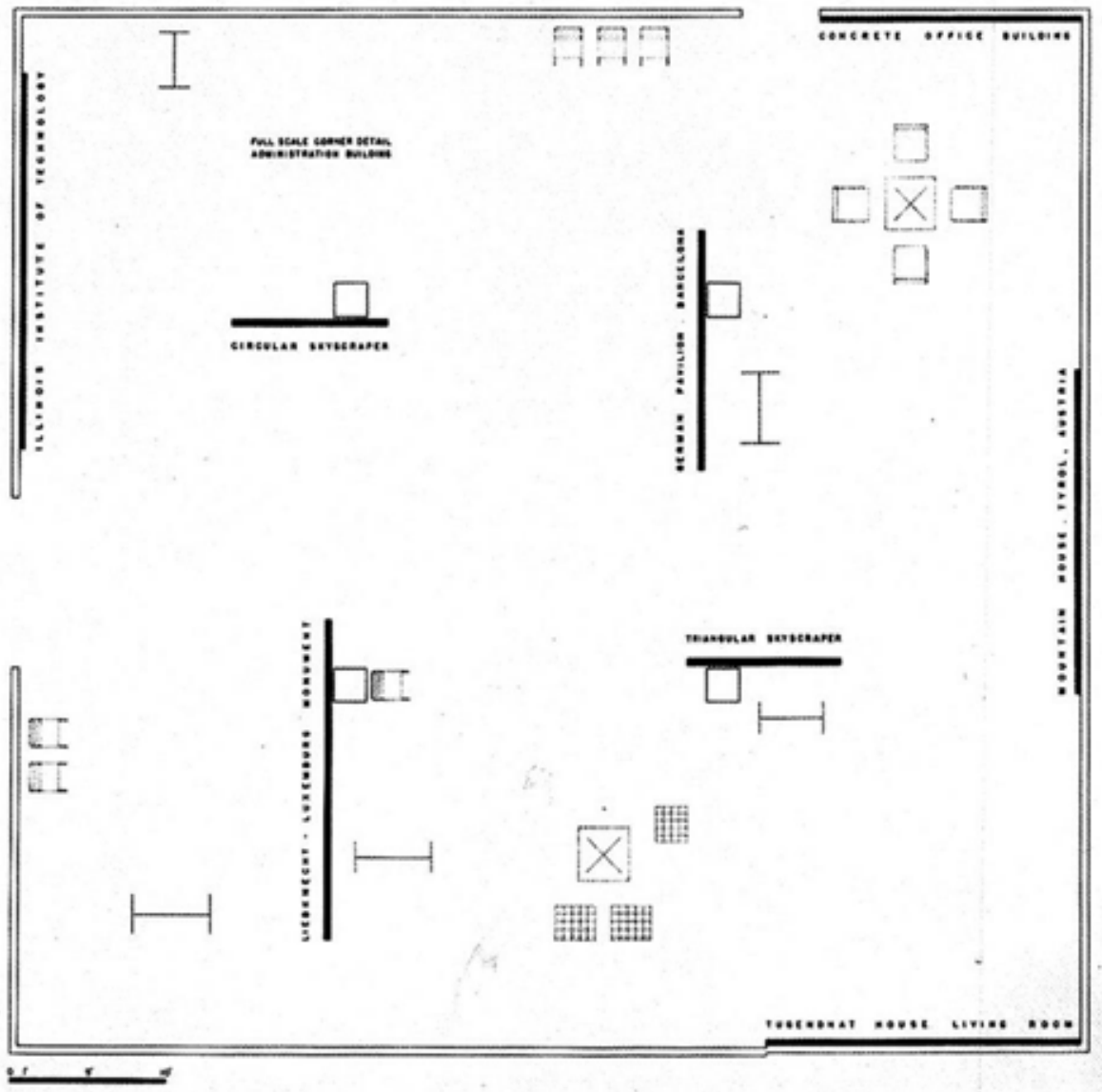

figura 12

Mies Van der Rohe, Plan of Exhibition, 1947

(Museum of Modern Art, Nova Iorque) 
foram expostas em pedestais como esculturas e fotos penduradas como se fossem pinturas, até as "atmosferas" propostas pela curadoria de Kazuyio Sejima e a direção artística de Ryue Nishizawa, na Bienal de Veneza, em 2010 - tornam-se possíveis, pela leitura e análise da história das exibições de arquitetura, gerar um mapeamento de como o espaço é problematizado e torna-se o protagonista destas exposições. Um exemplo claro dessa orientação é a exposição de Mies Van der Rohe, novamente no MOMA (figura 12), em 1947, onde fotos, desenhos e maquetes ganharam uma disposição que ocupava a galeria através de quatro planos perpendiculares intercalados no centro do espaço, e quatro painéis nas paredes do salão, conformando ambientes interligados que não estabeleciam uma hierarquia, e eram ocupados tanto pelo mobiliário desenhado pelo arquiteto quanto por maquetes, ou mesmo um detalhe em escala 1:1 para a solução de um edifício comercial. Esta disposição resulta claramente numa arquitetura "misiana" e corrobora com as imagens, desenhos e maquetes para o entendimento de sua arquitetura, estabelecendo uma leitura de sua obra também e, principalmente, pela organização do espaço do museu onde o que se observa não é uma adequação dos objetos a uma lógica da exposição de arte, mas a uma concepção de exposição entendida como uma arquitetura per se.

Outra importante abordagem que se desdobra com nítido caráter de instalação, na sua acepção difundida pelos meios artísticos contemporâneos, é o projeto de Lucio Costa para a primeira participação brasileira na XIII Trienal de Milão, em 1964, ano em que, segundo Ernesto Nathan Rogers ${ }^{64}$, o evento sai de um "coma" ao destacar como tema o tempo livre.

Lucio Costa equaciona o tema de forma econômica e bem humorada, sintetizando cultura popular brasileira, espacialidade moderna e cultura de massa contrapondo-se à mecanização do cotidiano com um gesto de fuga da rotina, incitando o público extenuado, e por vezes autômato destes eventos, a parar e relaxar. Riposatevi, título do pavilhão(figura 13), que significa "repouse" em italiano, contrapõe o tempo verbal imperativo ao convite do uso aberto do espaço pelo público. Uma espécie de varanda branca é

64 Editorial da Revista Casabella n²90, de agosto de 1964. "La Triennale uscita dal coma" p.1. 

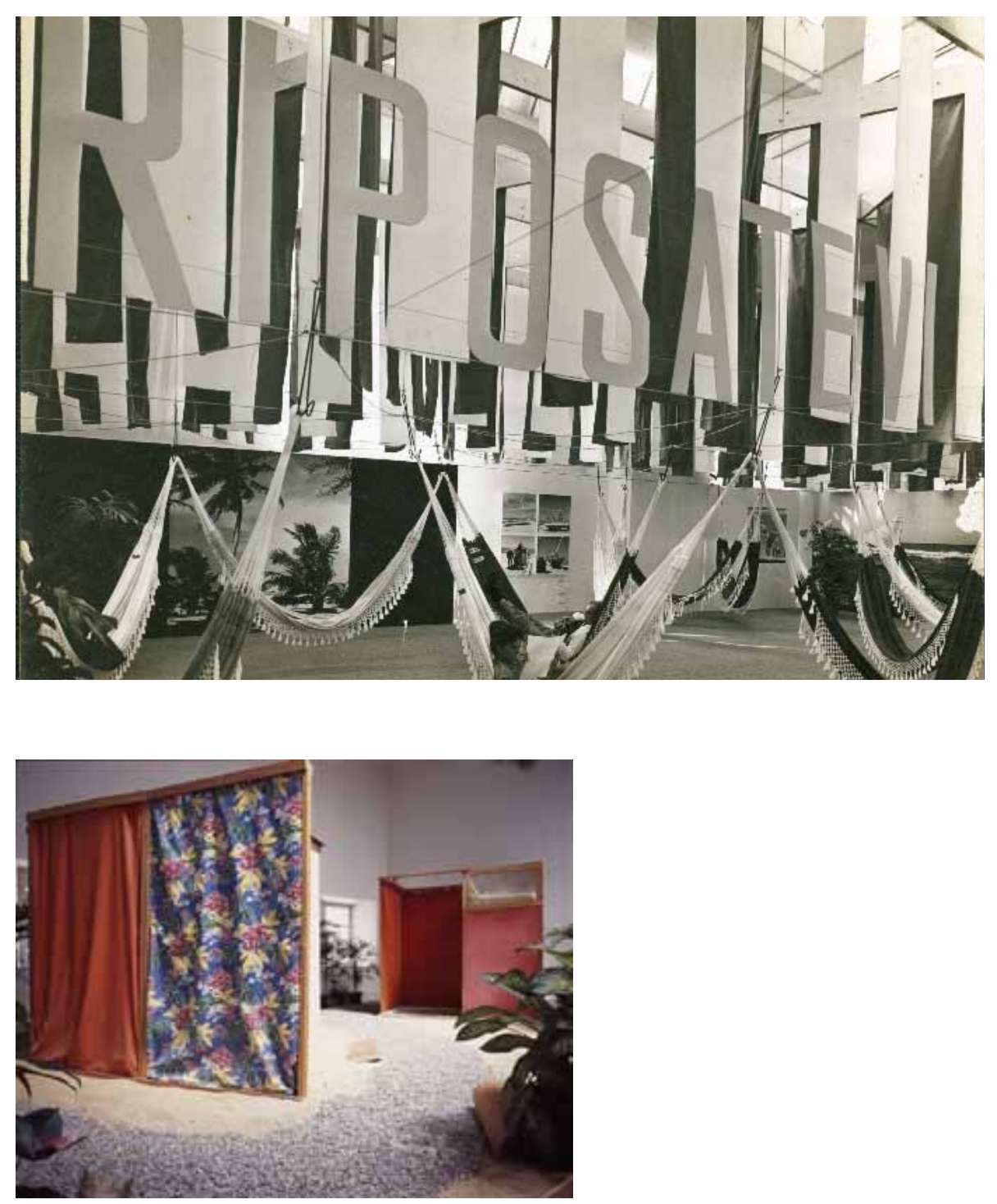

\section{figura 13}

Lucio Costa. Riposatevi -1964

(XIII Trienal de Milão, Itália)

\section{figura 14}

Hélio Oiticica. Tropicália PN2 e PN3, MAM - Rio de Janeiro - 1967

(remontagem em 2010 no centro Itaú Cultural, São Paulo) 
recriada no interior do grande edifício de exposições onde grandes imagens em branco e preto de Brasília, de jangadas, e do mar - de autoria do fotógrafo Marcel Gautherot -, se alternam ao arranjo de quatorze redes de algodão colorido e alguns violões dispostos sobre um piso de sizal. A trama de cabos de aço que sustenta as redes é pensada como um dossel que encabeça e ocupa o espaço aéreo com bandeirolas coloridas que comunicam o título-convite.

Esta instalação é oportunamente cotejada à "Tropicália” de Hélio Oiticica (figura 14), no ensaio de Eduardo Rossetti ${ }^{65}$ uma vez que ambas são: "uma tentativa consciente, objetiva, de impor uma imagem brasileira ao contexto atual da vanguarda e das manifestações em geral da arte nacional" 66 .

Exposta pela primeira vez no MAM do Rio de Janeiro, em 1967, “Tropicália” foi remontada somente em 1987, em São Paulo, por Guy Brett, que contou apenas com algumas fotos de registro da primeira montagem para executá-la, uma vez que registros e plantas eventualmente produzidos por Oiticica não foram localizados. Esta instalação é uma clara aplicação dos preceitos elaborados por Oiticica no texto de catálogo para a exposição "Esquema Geral da Nova Objetividade Brasileira" $(1976)^{67}$, partindo de uma consciência da antropofagia de Oswald de Andrade, como desejo de construção vanguardista capaz de abafar as influências internacionais e reinterpretá-las à maneira da cultura local. "Tropicália” supera o suporte do quadro e nega o objeto, envolve o espectador de forma tátil, visual e corporal, aborda problemas político-sociais do país, favorece proposições coletivas e propõe novas formulações de antiarte, através de um espaço discursivo que agrega pessoas e desperta para experiências sociais.

Assim como "Tropicália”, "Riposatevi” compartilha desta afirmação do caráter nacional impregnado de todas suas contradições, "do povo que constrói Brasília e descansa nas redes ${ }^{68}$ ". A elaboração

65 ROSSETTI, 2005. "Riposatevi, a Tropicália de Lucio Costa: o Brasil na XIII Trienal de Milão."Este artigo foi apresentado na forma de comunicação no VI Seminário DOCOMOMO Brasil, Niterói, e está presente no Cd dos anais e foi consultado através do no site: <http:// www.vitruvius.com.br/revistas/read/arquitextos/06.068/388> em 02 -12-2012.

66 OITICICA,1968. In: BASUALDO (org.). 2007, p.239-241.

67 In: FERREIRA-COTRIM (org.). Op. cit., p154-168.

68 ROSSETI, Op. cit., p.6. 
desta ideia não se dá apenas pelas imagens de Gautherot, mas sim pela experiência espacial que espelha o modo de vida partilhado nas favelas e nas construções espontâneas tanto quanto na capital do país, e, assim, lançando mão de recursos arquitetônicos e instalativos, Lucio Costa provoca reflexões importantes sobre a cultura brasileira, derrubando estereótipos e estruturas estabelecidas.

Exposições, bienais e trienais de arquitetura se firmaram como dispositivos de enfoque crítico ao explicitar os processos projetuais da arquitetura que operam como mecanismo de renovação da comunicação de pesquisas históricas, acadêmicas e críticas para um público mais abrangente. Essas plataformas operacionais ${ }^{69}$ são capazes de absorver investigações nem sempre possíveis no exercício da prática arquitetônica convencional voltada à construção. Neste processo, arquitetos se veem diante do paradoxo de expor a ausência do trabalho em si - o projeto executado - e, através de projetos expositivos que combinam recursos cenográficos, vídeos, novas tecnologias, além de procedimentos da arte contemporânea, explicitam o paradoxo da ausência do objeto ao trabalharem o espaço de exibição como a exibição do espaço. Por outro lado uma exposição de arquitetura seria capaz de propor a inversão de uma lógica, podendo a exposição, em si, ser uma arquitetura.

A prerrogativa de se revelar o espaço sem a mediação da representação gráfica, presente nas recentes bienais e exposições de arquitetura, encontra claro paralelo em diversas estratégias e operações artísticas em curso desde os anos 60. Levando-se em conta a especificidade do lugar e a participação do público, aproximamse da instalação na medida em que o espaço como meio propõe um estreitamento de limites disciplinares. Da mesma forma, o entendimento de que a instalação apresenta-se num estágio de hipertrofia refletida na expansão da obra do espaço da galeria para o edifício, da mesma forma, arte e arquitetura partem da ideia do pavilhão como unidade espacial autônoma ou uma meta-arquitetura.

69 Título de texto de Felicity Scott que parte do conteúdo de um curso criado pela Universidade de Columbia para tratar de crítica, curadoria e práticas conceituais e desdobrar a diversidade de atividades que podemos reconhecer como arquitetura hoje. Não se tratando apenas da obra construída, a arquitetura hoje deve abranger toda modalidade prática que trate de arquitetura para além de seu modo tradicional - projeto e construção edificada ressaltando a importância das exposições de arquitetura neste contexto.SCOTT. 2005, p.65-69. 


\subsection{Instalação: a arquitetura dentro da arquitetura.}

Segundo Clair Bishop, o termo "instalação" derivou do uso desta palavra por parte das revistas de arte que, no início dos anos 60, a empregavam para descrever a disposição de algumas exposições, onde a foto que documentava este arranjo era conhecida como "installation shot" e, a partir de então, toda obra que de alguma forma explorasse a articulação espacial envolvendo o espectador pela sua presença corporal e sinestésica passou a ser conhecida como instalação, uma vez que se distanciava das categorias tradicionais: escultura, pintura, fotografia ou vídeo.

Esta produção difusa teria como genealogia, segundo a autora, os trabalhos do suprematista russo El Lissitzky cuja obra "Proun" (figura 14) explicita o estado de mudança da pintura para a arquitetura. A “Merzbau” do dadaísta alemão Kurt Schwitters - e sua eterna construção de um ambiente habitável modelado pela sobreposição de fragmentos, objetos encontrados, colagens de recortes de jornal, espelhos e folhagens amalgamadas por camadas de gesso, resultando numa escultura abstrata penetrável (figura 15) - também pode ser reconhecida como uma de suas origens.

Os trabalhos e ações de Marcel Duchamp, que sempre tencionou as instituições artísticas, completam esta linhagem de obras, especialmente algumas intervenções simples e radicais, como a exposição Surrealista de Paris (figura 16), em 1938, na qual Duchamp desempenhou o papel de autor do projeto expositivo e produtor, reunindo um grupo de artistas que contava com Man Ray e Salvador Dalí, entre outros, para coletivamente intervirem na galeria, não somente na disposição dos quadros, mas em todo o ambiente, a começar pela remoção da decoração interna original do edifício. Os suportes expositivos para os quadros foram adaptados sobre estruturas de portas giratórias de lojas parisienses e a cobertura de vidro existente foi recoberta por sacos de carvão vazios e sujos de forma a 

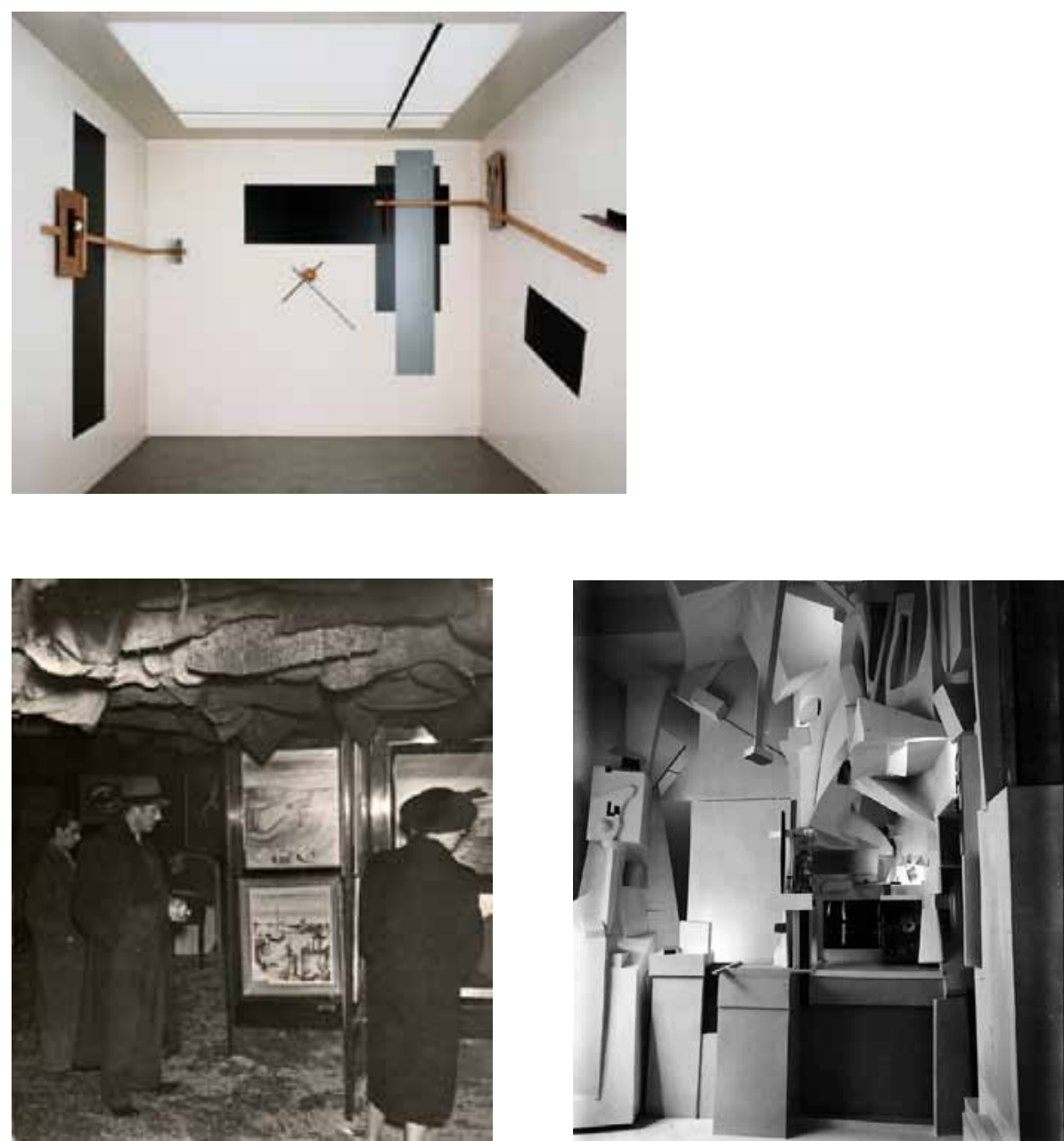

\section{figura15}

El Lissitzky, Proun Room - 1923.

(Remontado em 1971, Van Abbemuseum, Holanda)

\section{figura16}

Marcel Duchamp.Exposition International du Surréalisme, Paris -1938

\section{figura17}

Kurt Schwitters, Merzbau, 1932

(Remontado em 1983, Sprengel Museum em Hannover, Alemanha) 
impedir a entrada de luz e intensificar o efeito dramático, exacerbado na noite de inauguração por uma trilha sonora de gritos e marchas alemãs, e pela escuridão generalizada do local iluminado apenas por lanternas distribuídas aos convidados, contribuindo para que a experiência fosse acompanhada da carga psicológica e onírica desejada pelo grupo.

A combinação de teatralidade e espaço arquitetônico intensifica-se com as obras ambientais e happenings dos anos 50 e aproximam-se do conceito de Gesamtkunstwerke ${ }^{70}$ culminando com o questionamento da neutralidade privativa da galeria pela escultura minimalista, que esvaziada de qualquer significado e priorizando o uso de materiais fabricados industrialmente ambicionava "relocar as origens do significado de uma escultura para o exterior, não mais modelando sua estrutura na privacidade do espaço psicológico, mas sim na natureza convencional, pública, do que poderíamos denominar espaço cultural",71

Exposição e instalação apresentam-se, portanto, como expressões imbricadas, assim como espaço arquitetônico e instalação, especialmente no que diz respeito aos desdobramentos sociais que algumas obras conferem ao local onde se inserem, ativando o espaço pelo público - entendido tanto no sentido de espectador participante, como de espaço comum e social - característica primordial da prática arquitetônica.

Os arquitetos Alison e Peter Smithson contribuem para esta especulação com uma obra marcante em colaboração com os artistas Nigel Henderson e Eduardo Paolozzi na exposição “This is tomorrow" (1956), realizada na galeria Whitechapel, em Londres. "Patio and Pavilion" (figura 18) era um reflexo da consciência do lar como celebração da vida cotidiana em um local específico, o lugar engendrado pelas experiências decantadas ao longo do tempo e refletidas no acúmulo de objetos por parte de seus habitantes como forma de se construir uma consciência e um sentido ao lugar.

70 A ideia de obra de arte total, originalmente pensada por Richard Wagner, retomada por Walter Gropius e tornada a filosofia da Bauhaus é associada à instalação no texto "Towards Installation". In: OLIVEIRA-OXLEY-PETRY-ARCHER. "Installation Art." 1996, p. 14.

71 KRAUSS. In: Caminhos da Escultura Moderna.São Paulo, 2007, p. 323. 


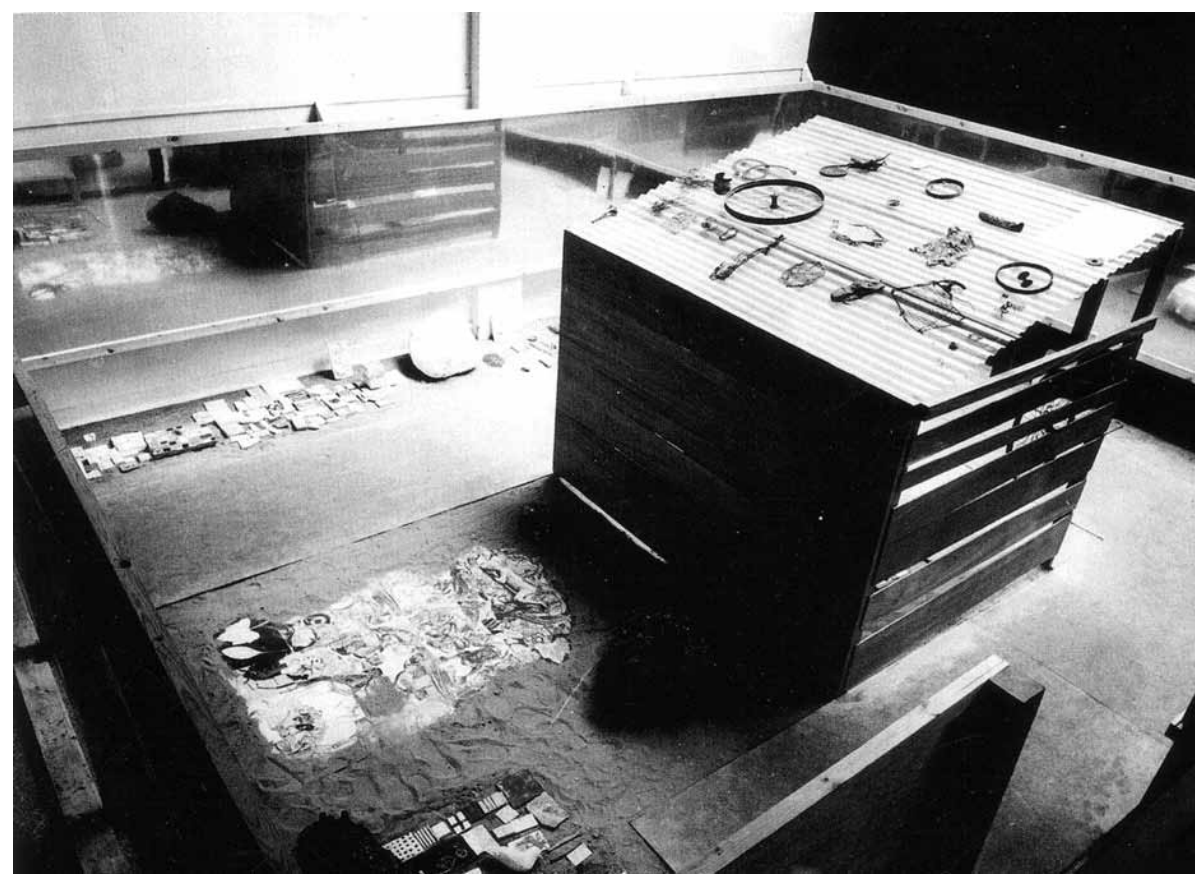

\section{figuras 18}

Alison e Peter Smithson, Nigel Henderson e Eduardo Paolozzi.

Patio and Pavilion - 1956.

(This is Tomorow Exhibition, Whitechapel Gallery, Londres) 
O casal Smithson cria uma estrutura dividida em dois espaços de forma a representar as necessidades fundamentais do abrigo humano. O pátio, como símbolo de um fragmento do mundo, é conformado por uma cerca em madeira de compensado que é forrado na sua face interior por uma superfície de alumínio reflexiva trazendo o espectador para a obra e, no interior, o pavilhão reflete a necessidade de um espaço fechado, uma cabana construída em madeira reciclada coberta com telhas de plástico translúcido. Esta estrutura foi posteriormente ocupada por Paolozzi e Henderson que espalharam os mais variados objetos dentro do pavilhão, sobre sua cobertura e por todo o piso do pátio, que recoberto de areia, remetia a uma espécie de escavação arqueológica futurista. Segundo Peter Smithson, ao contrário de diversas interpretações atribuídas à instalação na época, estes objetos não possuíam um significado especial, mas contribuíram para a desejada construção de um sentido metafórico da instalação ${ }^{72}$.

Alison Smithson desejava que esta exposição apresentasse as possibilidades de um novo campo de exploração partilhada entre arquitetos e artistas unidos em torno de trabalhos de arte em grande escala que poderiam ser entendidos não como mero desejo estético, mas como colaboração de ideias, no sentido de se satisfazer aspectos humanos ${ }^{73}$. Tomando como referência pavilhões do período heroico do movimento moderno dos anos 20 , onde eram apresentados os potenciais de uma nova forma de habitar da era da máquina - o pavilhão L'Esprit Nouveau de Le Corbusier e o pavilhão de Barcelona, de Mies van der Rohe - "Patio E Pavilion” simbolizava a inquietação de uma nova geração de arquitetos, que exposta ao avanço da cultura de massa, buscava alternativas à visão platônica de mundo proposta pelo movimento moderno, o que acabara resultando numa arquitetura de pura abstração formal onde a perfeição encontrava-se desconectada de seus usuários e do contexto. Assim, partindo de um alinhamento

72 COLOMINA-SMITHSON. Friends of the Future: A Conversation with Peter Smithson. In: October, Vol. 94, (Autumn, 2000), p. 27.

73 Conferência proferida na Universidadede Berkley, em Março de 1991, e transcrita na revista Places 7(3). Berkley: College of Environmental Design, 1991, p. 13. Nela, Alison Smithson questiona a iniciativa de reconstrução da obra em 1990, no ICA em Londres, e afirma que as questões sonhadas pela sua geração não poderiam ser reconstruídas por outra, justamente por acreditar que as memórias são elaboradas de forma diversa a cada geração, assim, o impacto da instalação jamais seria o mesmo, podendo mesmo funcionar como um anticlímax do sonho. 
a uma produção artística, dentro de uma tradicional instituição ligada às artes, "Patio E Pavilion" respondia simbolicamente às inquietações em curso na Europa, especialmente na Inglaterra do pós-guerra, no sentido de uma humanização da arquitetura que representava um contraponto à positividade moderna e ao período "de inocência do mundo da tecnologia"74.

No manifesto publicado no catálogo da exposição, o grupo que ficou conhecido como "independent group" apresentava uma construção dentro da construção da galeria, tanto no seu sentido literal instalativo, quanto na inclusão de reflexões sobre a arquitetura e a cidade dentro de uma esfera cultural de debates. A partir desta colaboração, o grupo estabelecia que:

"O trabalho do arquiteto de fornecer o contexto para o indivíduo perceber a si mesmo, e o trabalho do artista de dar sinais e imagens para os estados desta realização, reúnem-se em um fato único, cheio de inconsistências e irrelevâncias aparentes de cada momento, mas cheios da vida.» ${ }^{75}$

“Patio E Pavilion" dilui a relação do que poderia ser entendido como síntese das artes e estabelece novos parâmetros para o trabalho coletivo entre artistas e arquitetos. Também, da mesma forma que o pavilhão de Van Eyck para Sonsbeek, ao incluir o espectador como habitante da obra, esta instalação estabelece uma importante inflexão ${ }^{76}$, pois o pavilhão, como campo especulativo, assume tanto o papel de escultura - com vocabulário e escala arquitetônica - como também, no sentido inverso, resulta em uma arquitetura que se aproxima de procedimentos esculturais e artísticos. A autonomia do objeto artístico possibilita o questionamento da positividade implícita à prática arquitetônica, especialmente quando esta arquitetura é transposta para o contexto da exibição e da instituição artística, daí a utilização do pavilhão como resgate de uma arquitetura associada ao discursivo, tradicionalmente operando como catalisador de revisões críticas à própria disciplina, como um espaço aberto à reflexão.

74 Ibidem, p. 10.

75 "The architect's work of providing context for the individual to realize himself in, and artist's work of giving signs and images to the states of this realization, meet in a single fact, full of inconsistencies and apparent irrelevances of every moment, but full of life." SMITHSON, Alison. 1991, in: Places 7/3, p. 13

76 CURTIS. Op. cit., p. 137. 


\subsection{Espaço de reflexão. De Mies Van der Rohe a Dan Graham.}

O pavilhão alemão para a feira internacional de Barcelona, em 1929, é um caso paradigmático em seus diversos desdobramentos. Mies Van der Rohe é convidado a desenvolver o projeto em Maio de 1928, assim que o governo alemão concorda em participar da feira internacional de Barcelona, um ano antes de sua inauguração. Mies consegue, ao longo do processo, alterar o local original de implantação, já previsto numa área fora dos muros do palácio de exposição, mas escolhe uma posição que lhe confere uma articulação privilegiada, relacionando edifício e entorno - o que favorece ainda mais para que o pavilhão se destaque da sobreposição de diversas soluções figurativas reunidas dentro do centro de exposições. Assim, o pavilhão se vale de sua inserção no contexto urbano para sobressair-se, tendo a esplanada do parque Montijuïc como grande promenade e o muro cego do palácio de exposições com quem mantém uma relação de perpendicularidade, como pano de fundo que o destaca na paisagem.(figura 19)

Lili Reich e Mies Van der Rohe também se responsabilizaram por outras montagens para exibição de produtos e atividades industriais $^{77}$, mas o pavilhão de representação nacional, a casa da Alemanha, se limitava a receber os visitantes, dentre eles o Rei Afonso XIII da Espanha,(figura 20) presente na cerimônia de inauguração. Ao ser questionado sobre o que seria exposto no pavilhão, Mies teria respondido que nada seria exposto, o pavilhão por si só era a exposição, uma construção que respondia de forma efêmera e possível às suas investigações sobre "a casa de seu tempo", que segundo o arquiteto ainda não havia sido construída - afinal o tempo de resposta da arquitetura em relação a outras vanguardas artísticas, dadas as implicações de investimento e

77 A Exposição Internacional de Barcelona foi originalmente concebida na tradição de exposição industrial e não de nações. Somente durante os preparativos é que surge a intenção de se construir alguns pavilhões nacionais, e, considerando o ponto de vista político do primeiro pós-guerra, a Alemanha entende que sua participação é essencial. 

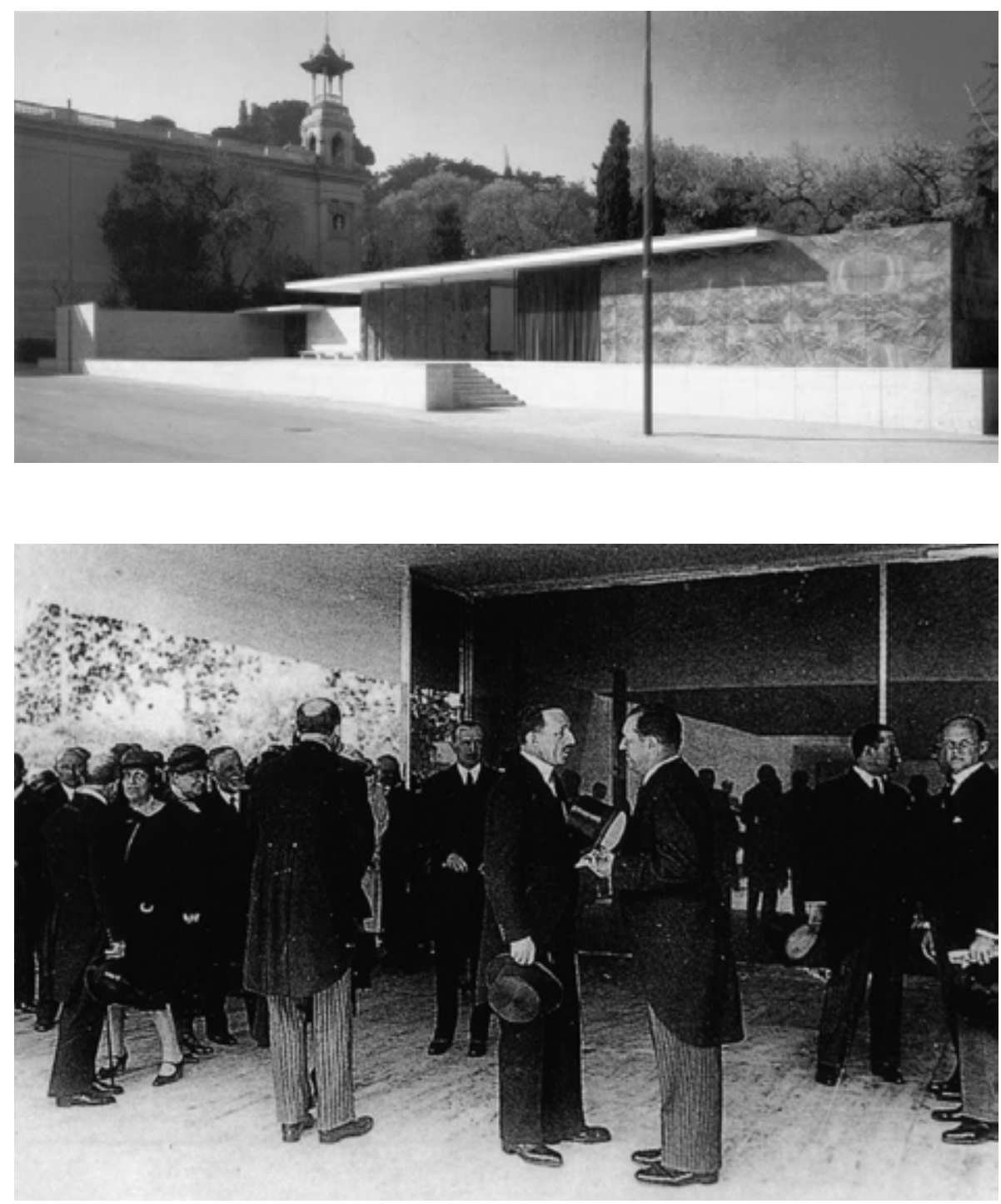

figuras 19 e 20

Mies Van der Rohe. Pavilhão de Barcelona -1929

(recontruído em 1986, Barcelona, Espanha) 
construção, são mais lentos.

O pavilhão de Barcelona pode ser entendido, portanto, como grande exemplo paradigmático de um edifício autorreferente, que serve também como corpo de provas para várias especulações do arquiteto até então. Nele é possível reconhecer as distribuições espaciais fluidas dos projetos para suas casas-pátio onde já estudava as delgadas coberturas em laje plana pousadas sobre os planos verticais, e apoiadas sobres os pilares de metal regularmente dispostos sobre a malha modular que se faz notar pelo desenho de um piso único, ampliando a sensação de continuidade entre interior e exterior. A alternância entre planos opacos e grandes superfícies em vidro provoca fenômenos de transparência, refração e reflexão já ensaiados nos projetos investigativos de arranhacéus $^{78}$, onde Mies aliava o uso do vidro ao esqueleto metálico que possibilitaria uma expressão máxima da estrutura racional.

Os fenômenos de reflexão exercidos pelo pavilhão de Barcelona foram destacados pela imprensa da época como misterioso efeito de onde era possível enxergar, a um só tempo, o próprio reflexo, o entorno do parque e o interior do edifício, e, uma vez em seu interior, enxergava-se o exterior perfeitamente (figura 20). Beatriz Colomina recorre a este depoimento anônimo e espontâneo publicado nos jornais da época, para contextualizar o quanto esta construção, naquele momento, exercia o fascínio do público diante do total desconhecido ${ }^{79}$ e assim conecta o pavilhão de Mies à obra de Dan Graham, uma vez que ambos exibem uma nova forma de observar, onde o público é envolvido num processo de espelhamentos que resultam em um jogo de exposição e dissimulação da própria imagem.

Dan Graham parte do pavilhão de Mies como referência de um marco canonizado pela história da arquitetura ${ }^{80}$ cuja

78 O concurso para o arranha-céu comercial, de 1919, para a Friederichstrasse, em Berlim e o desenvolvimento desta ideia no arranha-céu de vidro com superfícies curvas de 1920.

79 In:COLOMINA, "Beyond Pavilions, architecture as a Machine to See"(2008), p.69.

80 O Pavilhão de Barcelona serve como estudo de caso para J. P. Bonta, no texto "El sugimento de uma interpretación canónica", analisar a construção das sucessivas interpretações de uma obra de arquitetura ao longo do tempo, com suas variadas percepções, algumas esquecidas ao longo do tempo. In: BONTA, 1977, "Sistemas de significación em arquitectura”, p.149-193. 
consagração se dá pela grande repercussão de sua imagem destituída de materialidade - algumas fotos e desenhos do curto período em que esteve exposto, de março de 1929 a fevereiro de 1930 - o pavilhão de Barcelona acabou por tornar-se um esquema abstrato, distante da realidade concreta do edifício, corroborando para sua percepção como símbolo, em circunstâncias similares a uma obra de arte. A própria condição de representação nacional já conferia forte carga simbólica ao edifício ${ }^{81}$, e, especialmente após a publicação do livro "The International Style: Architecture Since 1922”, de Henry Russel Hitchcok e Philip Johnson, em 1932, o pavilhão passa a ser também reconhecido como uma síntese do que passou a ser conhecido como estilo internacional.

Assim, o pavilhão de Barcelona é tomado por Graham como índice para uma crítica à arquitetura e para a redução de sua utopia a um modelo de abstração que serve à ocupação das cidades contemporâneas pela lógica do capital. As pesquisas que se desdobram do pavilhão são aplicadas aos edifícios construídos por Mies nos Estados Unidos, como o Seagram (1958), em Nova Iorque. Dada sua forma abstrata, era de se esperar que esta arquitetura permanecesse destituída de qualquer contaminação ideológica, mas, ao contrário, a pureza da forma indiferente e não-comunicativa do estilo internacional passa a ser associada à imagem de grandes corporações implantadas em cidades em todo mundo como símbolo do capitalismo de exportação norteamericano. A transparência do vidro que eliminaria a distinção entre exterior e interior só amplia uma contradição na medida em que:

“a transparência literal do vidro não apenas objetiva de maneira falsa a realidade; ela é paradoxalmente uma camuflagem: pois enquanto a função real da corporação pode ser a de concentrar o seu poder independente e de controlar por meio de informações secretas, a sua fachada arquitetônica dá impressão de uma abertura absoluta. A transparência é

81 Ao encomendar o projeto o governo alemão estabelece que os valores de "claridade, simplicidade e integridade" deveriam ser expressos pela arquitetura do pavilhão que funcionaria como um emblema da nação. 
apenas visual: o vidro separa o visual do verbal, isolando quem está do lado de fora do local de tomada de decisões." 82

A arquitetura de grandes volumes de vidro translúcido revela-se difusa não somente em seu efeito óptico, mas especialmente numa esfera pública contemporânea, onde o vidro transparente atualiza-se nas grandes fachadas espelhadas de shoppings e edifícios corporativos que turvam o entendimento dos limites entre dentro e fora, entre público e privado nas cidades, refletindo uma sociedade onde o poder se exibe e se esconde em contornos intangíveis da mesma forma que espreita e controla cinicamente a esfera privada.

Graham apresenta seu primeiro pavilhão em uma Bienal de Veneza, em 1976. A obra "Public Space: Two Audiences" (figura 21) consistia em um espaço retangular dividido em duas salas quadradas, separados por um vidro à prova de som. Ao fundo de uma das salas, uma parede era espelhada, enquanto todas as outras eram brancas, assim como o teto que difundia uma luz uniforme através de uma grande claraboia. Os visitantes tinham que previamente aceitar a condição de, ao entrarem em uma das salas, permanecerem por dez minutos com as portas fechadas de forma a vivenciarem a necessária imersão de verem o público da outra sala enquanto estes os observavam, sentindo-se assim irrestritamente expostos. A arquitetura deste pavilhão proporcionava uma inversão de valores pela troca dos papeis entre a obra de arte, tratada como produto em feiras e exposições, colocando o espectador agora implicado neste jogo de forma desconcertante.

Vidro e outras superfícies, como chapas perfuradas, sobrepõem-se em diversos efeitos visuais na série de mais de cinquenta pavilhões que Graham produziu. Todas estas obras referem-se tanto à história dos pavilhões e seu universo autoreferente, como aos equipamentos urbanos cuja escala e funcionalidade oscilam entre o utilitário, o abrigo e o "não-lugar" comum à cidade contemporânea - reconhecido em pontos de ônibus e cabines telefônicas. Dentro de galerias ou inseridos no

82 GRAHAM,Dan. A arte em relação à arquitetura (1979). In: FERREIRA-COTRIM (org.) Op. cit, p.434. 


\section{PUBLIC SPACE / TWO AUDIENCES}
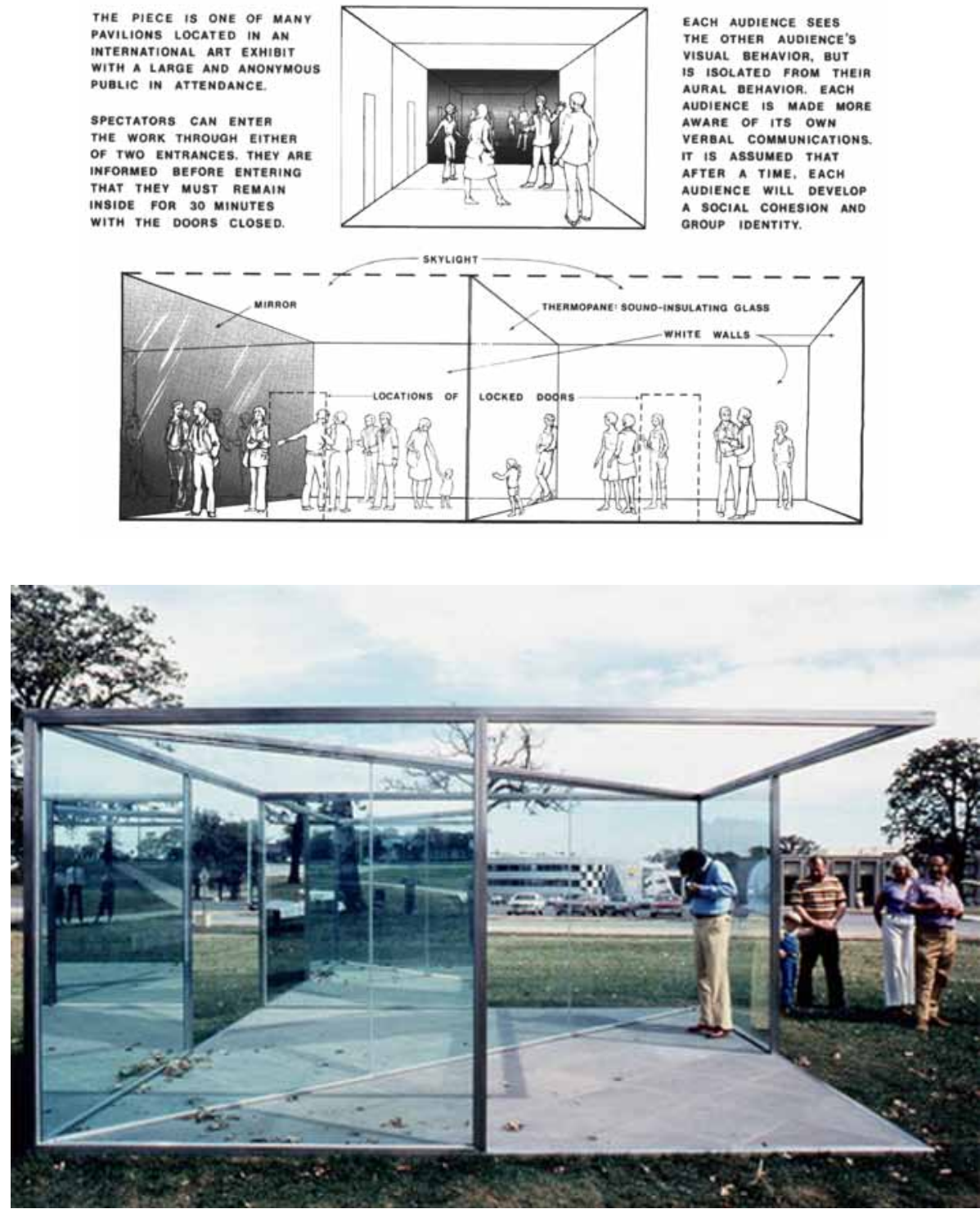

\section{figura 21}

Dan Graham. Public Spaces, Two Audiences - 1976.

(Bienal de Veneza, Veneza)

\section{figura 22}

Dan Graham. Pavilion/ Sculputure Aragonne - 1978-1981

(Aragonne National Laboratory, Chicago) 
contexto urbano, os pavilhões de Graham discutem as cidades e tomam a arquitetura como modelo, despertam no espectador a consciência de sua própria imagem envolvida nos diversos jogos de revelar e desaparecer, e provocam o público no sentido de uma necessária tomada de consciência da condição contemporânea com suas fragmentações e implicações alienantes.

Neste procedimento o artista descola o pavilhão de qualquer relação funcional tornando-o um elemento autônomo, e assim como já indicavam os pavilhões de Sonsbeek, conclui a tendência de convergência disciplinar apontada por Penélope Curtis ${ }^{83}$, uma vez que a escultura não complementa a arquitetura, nem o pavilhão abriga a escultura. Também em seus pavilhões o artista elimina a distinção entre assunto e objeto - o objeto é o espectador e o assunto é o espectador. Graham decodifica e canaliza códigos arquitetônicos e a maneira como estes códigos determinam o comportamento através da manipulação do espaço, o que leva Robert Smithson a afirmar que "Graham sabe ler a linguagem dos edifícios" ${ }^{4}$. Este deslocamento encontra no pavilhão a fusão entre o espaço que contém a obra e a obra em si, assim como no Pavilhão de Mies Van der Rohe, que, ao exibir a si próprio, tornara-se um monumento. Neste sentido, Graham assume a arquitetura de Mies Van der Rohe como ícone catalisador de sua discussão, resultando em um conjunto singular de pavilhões (figura 22) que, não por acaso, permeiam os estudos de caso que se seguem como chave para o entendimento de que o pavilhão revela uma tendência de convergência entre arte e arquitetura tornandose um dispositivo que possibilita uma reflexão sobre a própria condição da disciplina.

83 Ver o Capítulo 1 desta dissertação, p.29-35.

84 "Graham can read language of buildings" comenta Robert Smithson no artigo "A museum of Language in the Vicinity of Art"(1968) comentando o trabalho "Homes of America", uma compilação de textos e fotos de casas de subúrbios norte-americanos, publicadas por Graham no ano anterior na mesma revista, a Art International. SMITHSON. Apud ALBERRO, “Reductivism in Reverse",1994, p. 21. 
Parte II:
Análise
de
Casos 


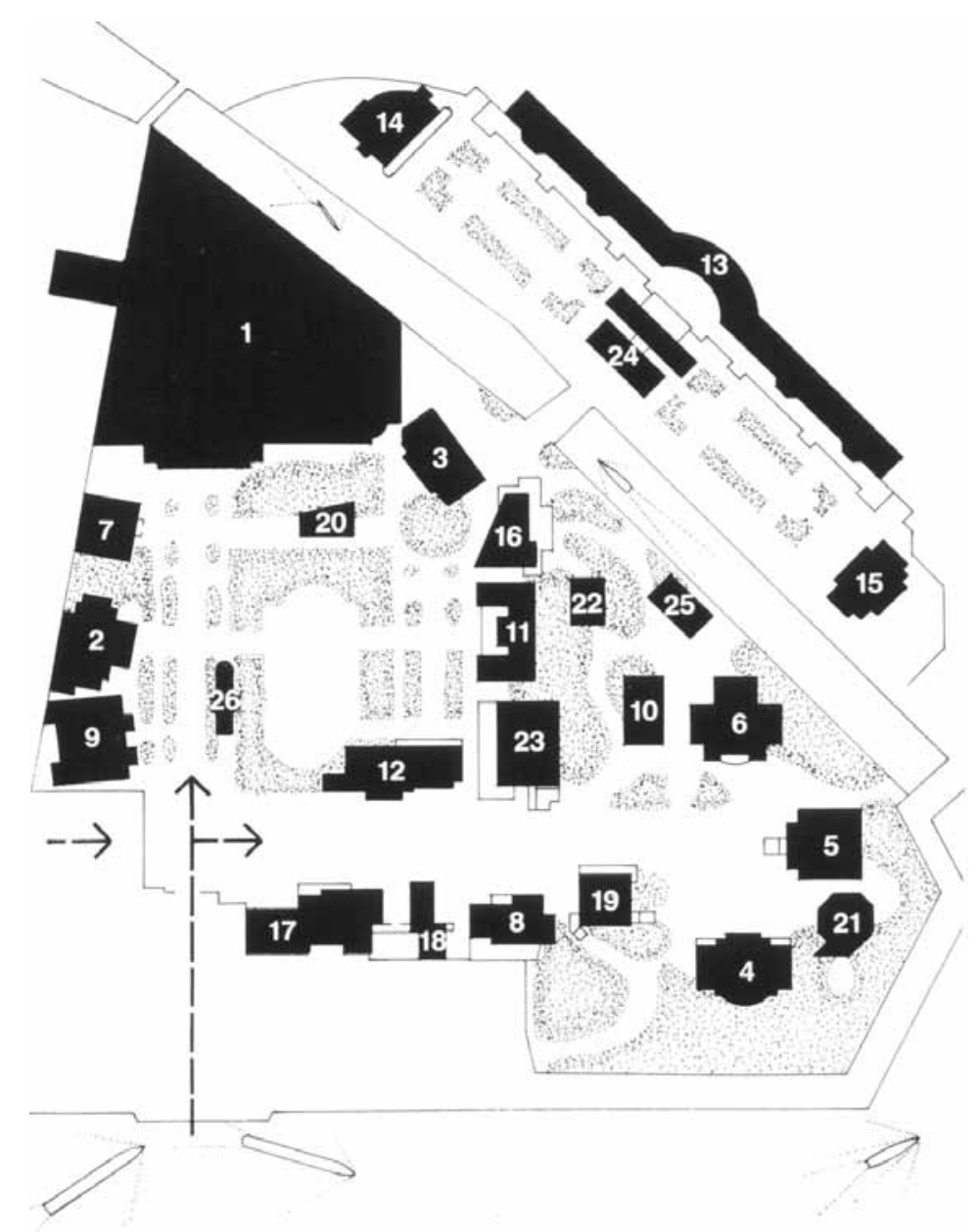

\section{figura 23}

Situação atual dos pavilhões do Giardino, Veneza.

Legenda: 1- Itália/La Biennale. 2- Bélgica. 3- Hungria. 4- Alemanha. 5- Grã-Bretanha. 6- França. 7- Holanda. 8- Rússia. 9- Espanha. 10-República Tcheca. 11- Estados Unidos. 12-Dinamarca. 13-Veneza. 14- Áustria. 15- Grécia. 16- Israel. 17- Suíça. 18-Venezuela. 19-Japão. 20-Finlândia. 21-Canadá. 22-Uruguai. 23-Países Nórdicos. 24-Brasil. 25- Pavilhão do Livro. 


\section{Bienal de Veneza}

\subsection{Os pavilhões do Giardino}

A Bienal de Arquitetura de Veneza intercala-se à Bienal de Arte ${ }^{85}$ no calendário desta Instituição desde sua criação, em $1980^{86}$, e acontece tradicionalmente em duas principais estruturas na cidade, o grandioso Corderie dell'Arsenale - um dos maiores edifícios dedicado à produção pré-industrial, construído no século XVI, onde se fabricava cordas para o estaleiro que ajudou a conferir à Veneza seu poderio naval e nos pavilhões das representações nacionais no parque público do Giardino, erguidos a partir de 1907 como estratégia de consolidação do sucesso internacional da mostra de artes, ao lado da construção central pré-existente - o pavilhão Itália hoje pavilhão La Biennale. Os pavilhões do Giardino (figura 23) incrementam a pesquisa por se tratar de um conjunto contruído, permanente, e de grande importância arquitetônica, constituindo uma referência de "coleção de pavilhões" nos moldes encontrados em outras instituições contemporâneas ${ }^{87}$, e se considerados os últimos trinta anos, servem também como potente estudo de caso dos choques entre a produção de instalações e espaço,

85 A primeira Bienal de Arte de Veneza acontece em 1895, presidida pelo poeta e prefeito da cidade Riccardo Selvatico, que orienta a ocupação de alguns edifícios reestruturados nos "Giardini Di Castello". Desde sua origem a exposição focou estritamente na produção artística consolidando-se como a primeira dentre as exposições internacionais de Arte mais importantes do cenário mundial.

86 Em dezembro de 1928 é constituída a agencia autônoma responsável pela organização do evento que, até então, era de responsabilidade da cidade de Veneza e, a partir de 1930 o evento desdobra-se no Festival de Música Contemporânea. Em 1932, é expandido também para a Mostra Internazionale d'arte Cinematográfica, e, em 1934, surge o Festival Internacional de Teatro, em 1998 o Festival de Dança, além da já citada Bienal de Arquitetura, criada em 1980.

87 Museu Kroller Müller, na Holanda, o Vitra Campus, na Alemanha ou o Benesse Art site Naoshima, no Japão, e o no Jinhua Architecture Park, na China são alguns exemplos de instituições onde os pavilhões ganham a importância de uma "coleção de arquiteturas", além do Inhotim em Minas Gerais, abordado no quarto capítulo desta dissertação. 
tanto em Bienais de Arte, quanto em Bienais de Arquitetura.

No contexto do início do século XX a exposição se espelhava nas Exposições Universais ao se estruturar em torno de representações nacionais, mas enfocava estritamente a produção artística em oposição à demonstração de competitividade industrial apresentada no evento modelo. Assim foram construídos os pavilhões permanentes da Bélgica, o primeiro em 1907, seguido de Hungria, Bavária (posteriormente Alemanha), Grã-Bretanha em 1909 e França e Holanda, em 1912. O caráter representativo destes edifícios expressos por uma arquitetura capaz de legitimar uma identidade nacional, representativa das conquistas tecnológicas de então, ganha força no primeiro pósguerra com os pavilhões da Espanha e da Rússia e as consequentes reestruturações nos pavilhões já existentes. Decoros são removidos e apagados, mastros e bandeiras adicionados e a cada edição a necessidade de um depoimento sobre realidades nacionais levava a constantes atualizações das fachadas.

Internamente estes primeiros pavilhões tendem a uma volumetria clássica, iluminada e neutra funcionando como um espaço para a arte, um suporte para o trabalho de artistas, curadores e cenógrafos. É assim que Jean-Louis Cohen ${ }^{88}$ descreve o pavilhão francês (figura 24) de autoria do arquiteto Fausto Finzi ${ }^{89}$, um verdadeiro cubo branco muito antes da arte contemporânea demandar este tipo de espaço. A resposta por parte dos artistas e arquitetos, especialmente nas edições mais recentes das bienais, segundo Cohen, justifica este partido como uma eficiente decisão que reverbera atualmente nas inúmeras possibilidades de transformação do espaço expositivo, a exemplo das instalações "Chance (les jeux sont faits?)" de Christian Boltanski, em 2011, e "The ultra Black - Grand Soir", de Claude Lévèque, em 2009, ou mesmo a proposta de, de fato, habitar o pavilhão durante a X Bienal de Arquitetura em 2006, proposta por Patrick Bouchain e a sua "Metavilla".

88 Jean-Louis Cohen, historiador, crítico e curador de arquitetura francês em ensaio para o projeto Common Pavilions dos arquitetos Diener \& Diener apresentado na $13^{\circ}$ Bienal de arquitetura, 2012, disponível no site do projeto: http://www.commonpavilions.com/pavilionfrance.html.

89 Fauso Finzi foi um engenheiro local responsável por construções da municipalidade veneziana. Jean Louis Cohen entende que a modesta solução arquitetônica do pavilhão seria uma possível "estratégia de desdém" da representação francesa. Ao não designar um de seus arquitetos reconhecidos por pavilhões em exposições Internacionais a França poderia estar demonstrando um desinteresse, naquele momento, pela Bienal. 

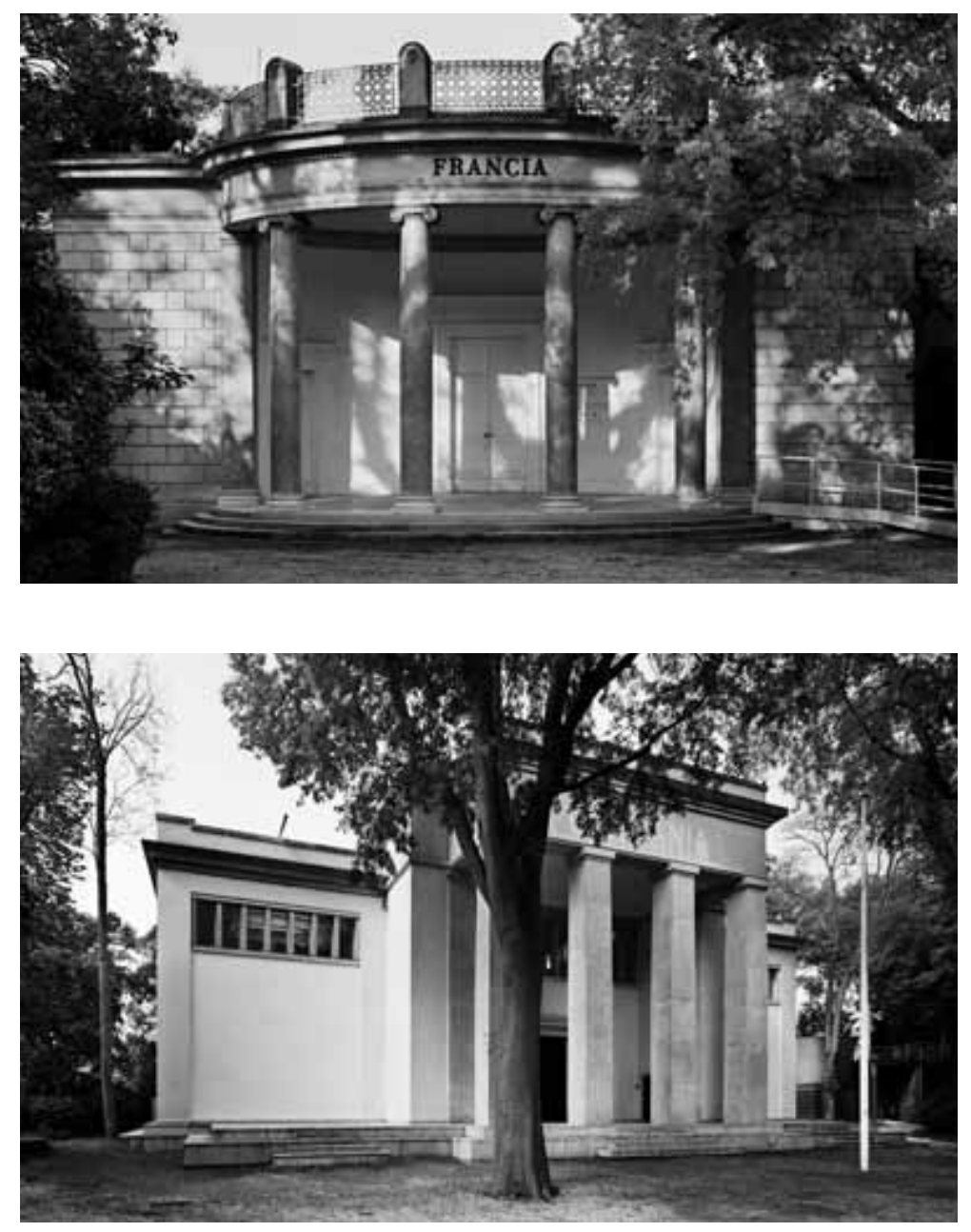

figura 24

Fausto Finzi. Pavilhão França - 1912

figura 25

Ernest Haiger. Pavilhão da Alemanha - 1938

(Giardino, Veneza) 
No caso alemão (figura 25), a arquitetura neoclássica resultante do último projeto de alteração do pavilhão original, que culminou com sua demolição quase que integral e reconstrução com projeto do arquiteto Ernest Haiger ${ }^{90}$, em 1938, é indissociável de seu passado nacionalista nazista e instiga sistematicamente as intervenções e contestações de artistas quanto à carga histórica impregnada ao espaço do pavilhão. Destaca-se o caráter específico ${ }^{91}$ de relação entre trabalho artístico e pavilhão, não somente no que diz respeito à sua espacialidade, mas, especialmente, à sua carga discursiva, social e institucional.

O trabalho "Tram Stop”, de Bueys, na trigésima sétima Bienal, em 1976, lidava com as memórias de um monumento vivenciado pelo artista em sua infância e pela recuperação de artefatos, que retrabalhados, reconstruíam o ambiente a partir de três elementos de ferro relacionados: um cano de canhão fincado verticalmente como mastro de cujo topo emergia uma cabeça modelada pelo artista e em torno da qual foram dispostas quatro bombas do século XVII, ao lado, uma linha horizontal emergia e voltava ao solo, e de outro um tubo escavado era preenchido pela água de Veneza. Com estes elementos Beuys estabelecia uma relação entre características da cidade de Cleaves, na Alemanha - cidade onde cresceu -, e o ambiente do pavilhão, entre a carga histórica recente de seu país e o ambiente ativado por sua memória, na busca por um processo de cura. Já o trabalho de Hans Haacke, "Germania"92 (figura 26), de 1993, que lhe rendeu o leão de ouro, reproduz o nome do pavilhão em seu interior sobre o que restou do piso de mármore destruído por ele e adiciona uma parede de fundo vermelha à porta de entrada, sobre a qual se encontrava a foto da visita de Hitler ao pavilhão, em 1934, e uma reprodução ampliada da moeda de um marco alemão, ampliando a carga

90 Arquiteto alemão que nos anos 30 e 40 foi responsável pela edificação que projetos nazistas na cidade de Munique.

91 No sentido elaborado por Miwon Kwon, onde site-specific não significa apenas uma obra pensada para um local onde a arquitetura é moldura física que estabelece as particularidades da obra, mas também abarca outras instâncias de investigação, como a crítica institucional relacionada ao espaço, abrindo-se para processos econômicos, sociais e políticos.

92 Germania em italiano quer dizer Alemanha, mas também corresponde ao nome que Hitler atribuiu à Berlin nazista. 


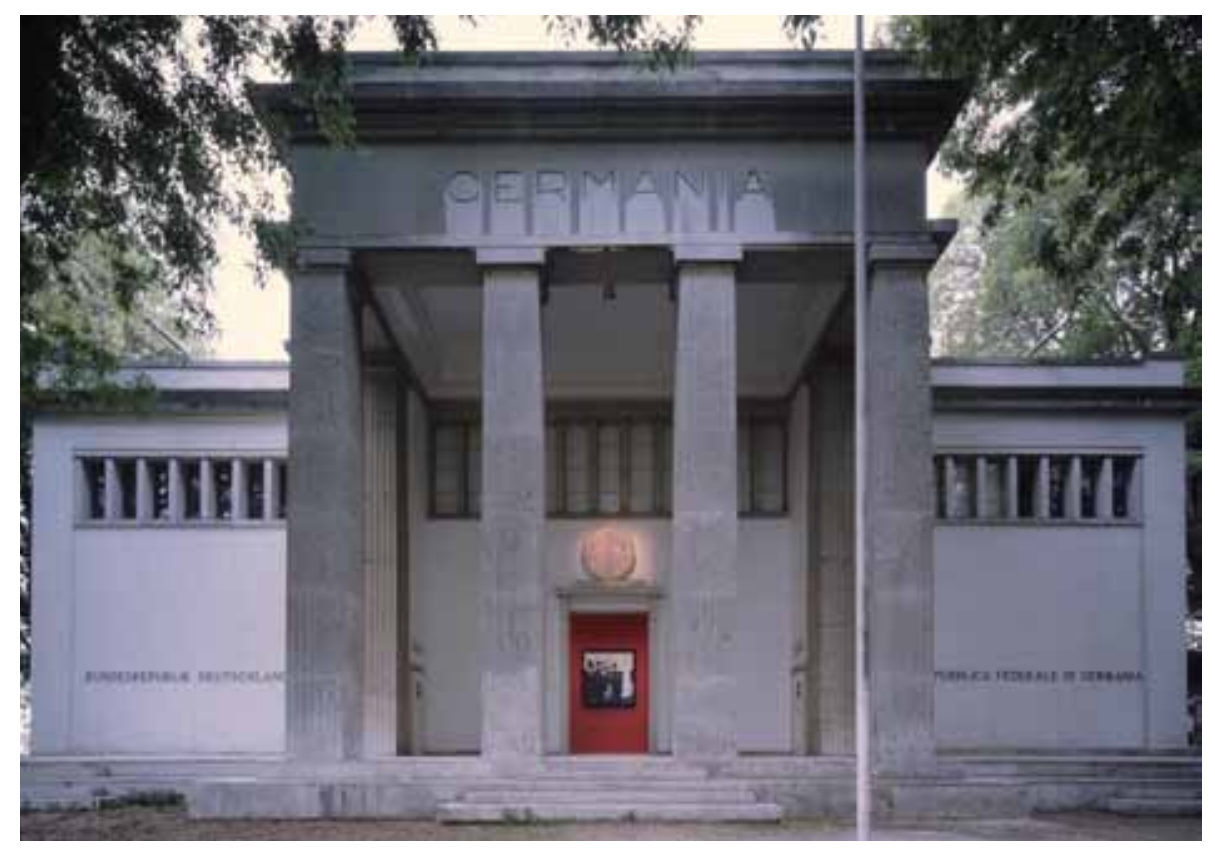

figura 26

Hans Haack. Germania - 1993

(Pavilhão da Alemanha, Giardino) 
dramática da composição da fachada. Essa investigação crítica expressa nas obras contribui para acirrar a discussão internacional sobre a quem caberia uma decisão em relação à demolição e reconstrução de um novo pavilhão que pudesse representar a Alemanha contemporânea ${ }^{93}$.

Nos anos 30 são construídos os pavilhões da Dinamarca e dos Estados Unidos - de autoria dos arquitetos Carl Brummer e da dupla Chester Holmes Aldrich e William Adams Delanonel respectivamente - conformando no parque um pátio central contíguo às das duas vias principais de distribuição, perpendiculares entre si. Posteriormente inicia-se a ocupação da outra ala do parque, mais estreita e separada pelo canal, onde é implantado o conjunto projetado pelo arquiteto Brenno Del Giudicce em 1932 que inclui o pavilhão Veneza - que abriga diversas nações a cada exposição - e os pavilhões da Polônia, Iugoslávia (hoje Sérvia) e da Romênia, seguidos dos pavilhões da Grécia, do arquiteto M. Papandréou, e Áustria ambos em 1934. Este último com projeto de Joseff Hoffman (figura 27), restaurado por Hans Hollein em 1984, é considerado um marco inicial da arquitetura moderna no Giardini, valendo-se de uma abstração formal em detrimento do uso de decoros e uma proposta que estabelece a entrada diretamente pela grande galeria de exposições, sem a necessidade do hall de distribuição das construções clássicas, resultando na grande fluidez espacial interna interligada ao pátio externo.

É justamente esta sobriedade característica do pavilhão austríaco que é subvertida ao ser "soterrada" por um novo edifício em “The Last Land”(figura 28), criado por Hans Schabus para a Bienal de 2005, um dos mais potentes choques entre escultura ${ }^{94}$ e pavilhão. Externamente, esta arquitetura amorfa parecia uma grande montanha rochosa - referência à paisagem típica austríaca - que obrigava o público a contorná-la para entrar no edifício pelos fundos do pavilhão e então ser conduzindo por um labirinto de escadas e rampas, estruturados caoticamente por sarrafos de madeira num complexo

93 O pavilhão alemão foi tombado como monumento histórico pelo órgão de conservação da cidade de Veneza.

94 Schabus em entrevista publicada no periódico Flash Art na edição Julho-Setembro se declara um escultor por acreditar que seu trabalho lida com a organização de materiais no espaço e, que a escolha destes materiais reforça esta categoria pelo processo de confecção envolvido no processo do fazer. 

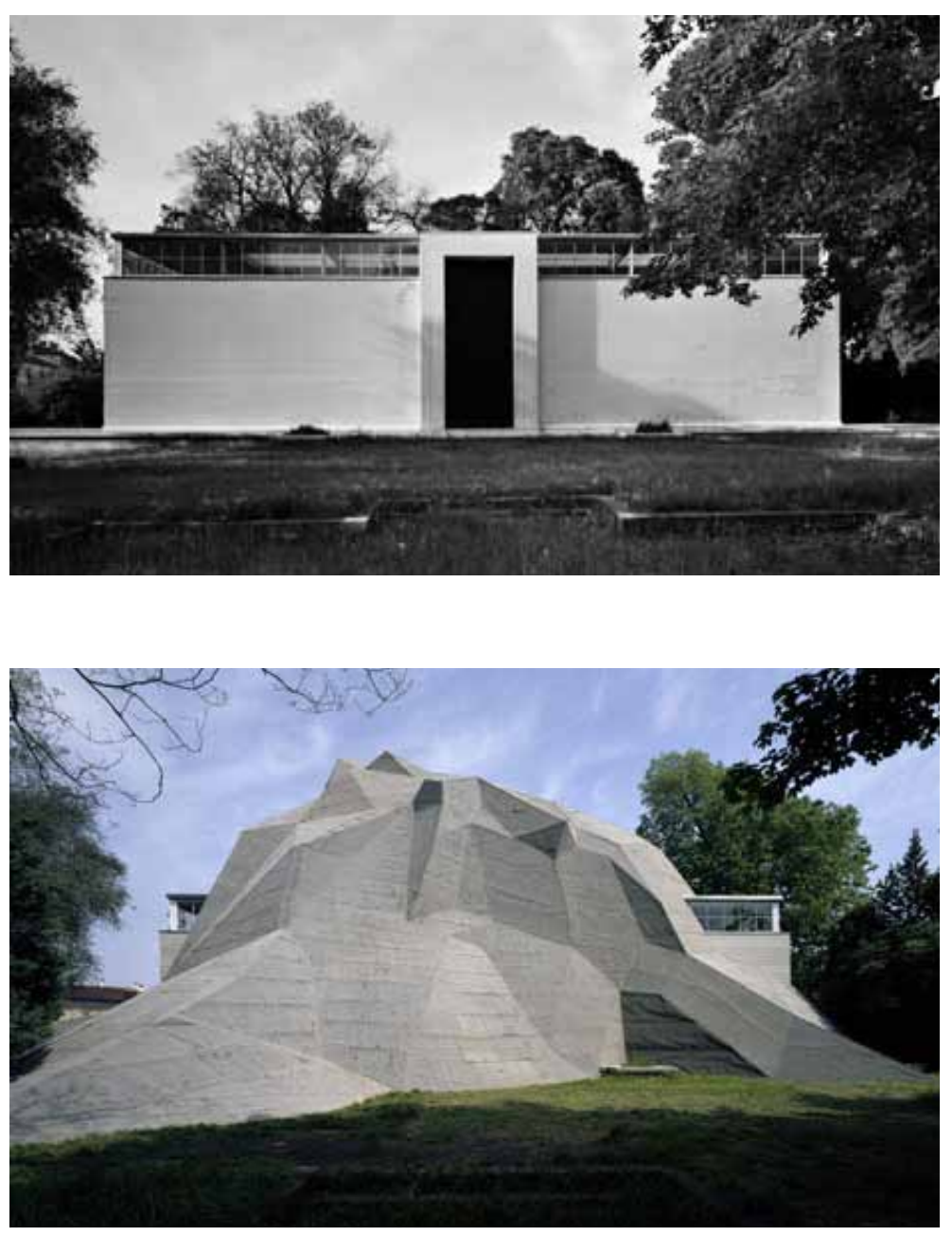

figura 27

Josef Hoffmann. Pavilhão Áustria - 1934

figura 28

Hans Schabus. "The Last Land" - 2005

(Giardino, Veneza) 
serviço de carpintaria, até atingirem a cobertura e se depararem com uma vista panorâmica de Veneza.

Os pavilhões com arquitetura moderna, construídos nos anos 50 e 60, saturam definitivamente o parque em uma corrida das nações por representatividade cultural no evento que já havia conquistado reconhecimento internacional no segundo pós-guerra. A arquitetura, agora impregnada das características específicas do Movimento Moderno desenvolvido em cada país, passa a potencializar o espaço como sua principal matéria conferindo ao parque uma coleção de arquiteturas notáveis. Como resultado são erguidos pavilhões que se distanciam da neutralidade do cubo branco entendido como "natureza sacramental do recinto" onde se propõe uma "galeria ideal que subtrai da obra de arte todos os indícios que interfiram no fato de que ela é arte, isolada de tudo que possa prejudicar sua apreciação de si mesma" 95 .Os pavilhões deste período destacam-se, tanto pela diversidade e particularidade dos projetos, preocupados em espelhar uma autoimagem nacional, quanto pelo contexto do parque que os acolhe, ou mesmo pelas características das Bienais que abrigam, promovendo um constante atrito entre estas arquiteturas e as obras de arte - instalações e obras site-specific que acolhem.

Bruno Giacometti, irmão do famoso escultor, é o vencedor de um concurso nacional e projeta o pavilhão da Suíça, inaugurado em 1952, que resulta em uma espécie de museu moderno em miniatura, contemplando volumes diversos permeados pela luz e o verde do parque, articulados entre si e estruturados de acordo com uso, destina um salão para pintura com iluminação zenital, outro para esculturas, integrado ao jardim de esculturas, e ambos conectados pela galeria avarandada e destinada às artes gráficas, alternando pés direitos e revestimentos.

O pavilhão de Israel, projeto do arquiteto Zeev Rechter, também de 1952, possui volumetria única e enclausurada, cuja casca é levemente solta do solo conferindo certa leveza à grande caixa, angulada de acordo com eixo da via de circulação do parque. Seu

95 O’DOHERTY. 2002, pg.3. 
volume é determinado pelos percursos, tanto por sua implantação que reflete na geometria da planta a inflexão do desenho do parque quanto por níveis impressos na fachada. Os três ambientes distribuídos em três níveis são visualmente interligados e determinam um percurso circular através da sua circulação em escadas.

Gerrit Rietveld projeta o segundo pavilhão holandês em 1954 (figura 29), ao lado do original, com uma composição que, em planta, relembra os procedimentos gráficos de Mondrian. Partindo de um quadrado, Rietveld rotaciona trechos de três das suas hastes de perímetro, conformando três pequenos ambientes e três aberturas, duas grandes janelas e o acesso principal. O espaço é apreendido desde sua volumetria externa, e o grande salão e seus pequenos recintos interligados são também marcados por uma luz filtrada que varia durante o dia de acordo com a orientação dos sheds, resultado da variação do pé-direito. Segundo Herman Heztberger, trata-se de um museu em pequena escala pensado para repercutir a arte holandesa, e ainda, pela sua articulação espacial e características, ressoar valores nacionais como simplicidade e transparência ${ }^{96}$.

Alvar Aalto projeta um pavilhão temporário para Finlândia (figura 30), em 1956, onde evoca características da construção vernacular de seu país e trabalha com peças de madeira pré-fabricadas pensando-o como um protótipo de museu em pequena escala ${ }^{97}$, mas que por um problema de fabricação dos componentes de ligação das peças resultou numa construção de caráter definitivo. No mesmo ano, Takamasa Yoshikaza, arquiteto que havia trabalhado com Le Corbusier, projeta o pavilhão japonês como um volume que se acomoda na colina do parque suspenso por pilotis.

Peter Koch amplia o pavilhão da Dinamarca, em 1958, e tira

96 O termo "northern air" foi usado por Herman Hertzberger - arquiteto, professor e crítico de arquitetura holandês - em seu texto sobre o pavilhão Holandês escrito para o projeto Common Pavilions, da $13^{\circ}$ Bienal Internacional de Arquitetura de Veneza a escrever um ensaio sobre o pavilhão holandês. <http://www.commonpavilions.com/pavilion-netherlands.html >

97 O argumento de que pavilhão funcionou como balão de ensaio em menor escala para experimentar situações projetuais que Aalto vinha buscando para outros projetos de maior escala é defendido por Juhani Pallasmaa, arquiteto finlandês e professor emérito da Universidade de Helsinki, no ensaio sobre o pavilhão da Finlândia para o projeto Common Pavilions da $13^{\circ}$ Bienal Internacional de Arquitetura de Veneza. <http://commonpavilions.com/ pavilion-finland.html> 

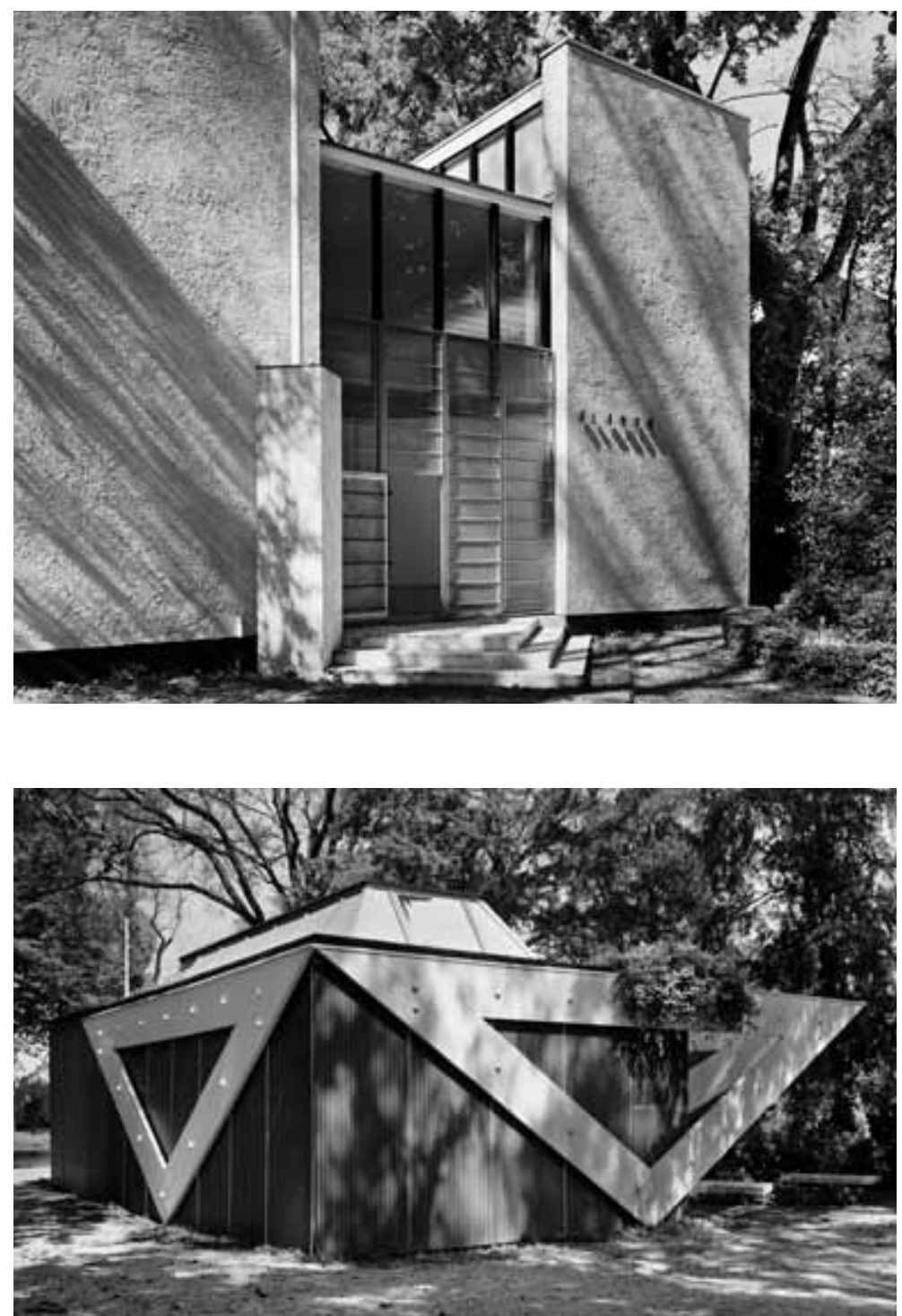

\section{figura 29}

Gerrit Rietveld. Pavilhão Holanda - 1954

\section{figura 30}

Alvar Aalto. Pavilhão Finlândia - 1956

(Giardino,Veneza) 
grande partido da implantação fazendo com que o novo bloco funcione como salão de acesso ao pavilhão original de Carl Brummer e assim conecta duas áreas do parque, rompendo com a relação de frente e fundos das fachadas, estabelecida pela construção original. Relacionando-se com a construção original, reconhecida pela harmonia da proporção palladiana ${ }^{98}$ de sua colunata, o longilíneo pavilhão com baixo pé-direito, opta por recobrir e envolver a fachada de fundos, voltada para a via de acesso do parque, sem a mesma importância da colunata que é mantida e destacada a partir do pátio central do Giardino.

Em 1962, é inaugurado o pavilhão dos países nórdicos (figura 31), projeto de Sverre Fehn, arquiteto norueguês que vence o concurso organizado por Suécia, Noruega e Finlândia - que contava com um representante indicado por cada país - com uma solução simples em galeria única, aberta e iluminada por luz natural filtrada pela sobreposição de vigas de concreto transversas e sobrepostas, interrompidas, quando necessário, para incorporar as árvores existentes. Sua implantação também contempla, assim como vizinho dinamarquês, uma abertura para via de acesso do parque, mas Fehn cria um recinto avarandado e recoberto pelo prolongamento das vigas, conformando uma pérgula que convida o espectador a entrar no ambiente como continuidade natural do percurso. Deste terraço parte a larga escadaria que aproveita o desnível mais íngreme do Giardino, e sob a qual se resolvem os serviços - um pequeno depósito e banheiro. Em oposição às duas grandes entradas, paredes, também em concreto, contêm o desnível do terreno e reverberam a luminosidade acinzentada associada à sensação de uma luz típica dos países nórdicos. O pavilhão dos países nórdicos articula-se assim para dois ambientes importantes do parque, integrando-os através de suas aberturas de grandes caixilhos corrediços em madeira e vidro. Rua de acesso e praça central conectam-se pelo pavilhão, que dilui a noção entre dentro e fora, tanto pela intensidade da luminosidade filtrada, como pela assimilação das árvores existentes na arquitetura.

98 A proporção de espaçamento ideal entre as colunas, segundo Andrea Palladio, corresponde a $1 / 3$ da altura das colunas. 

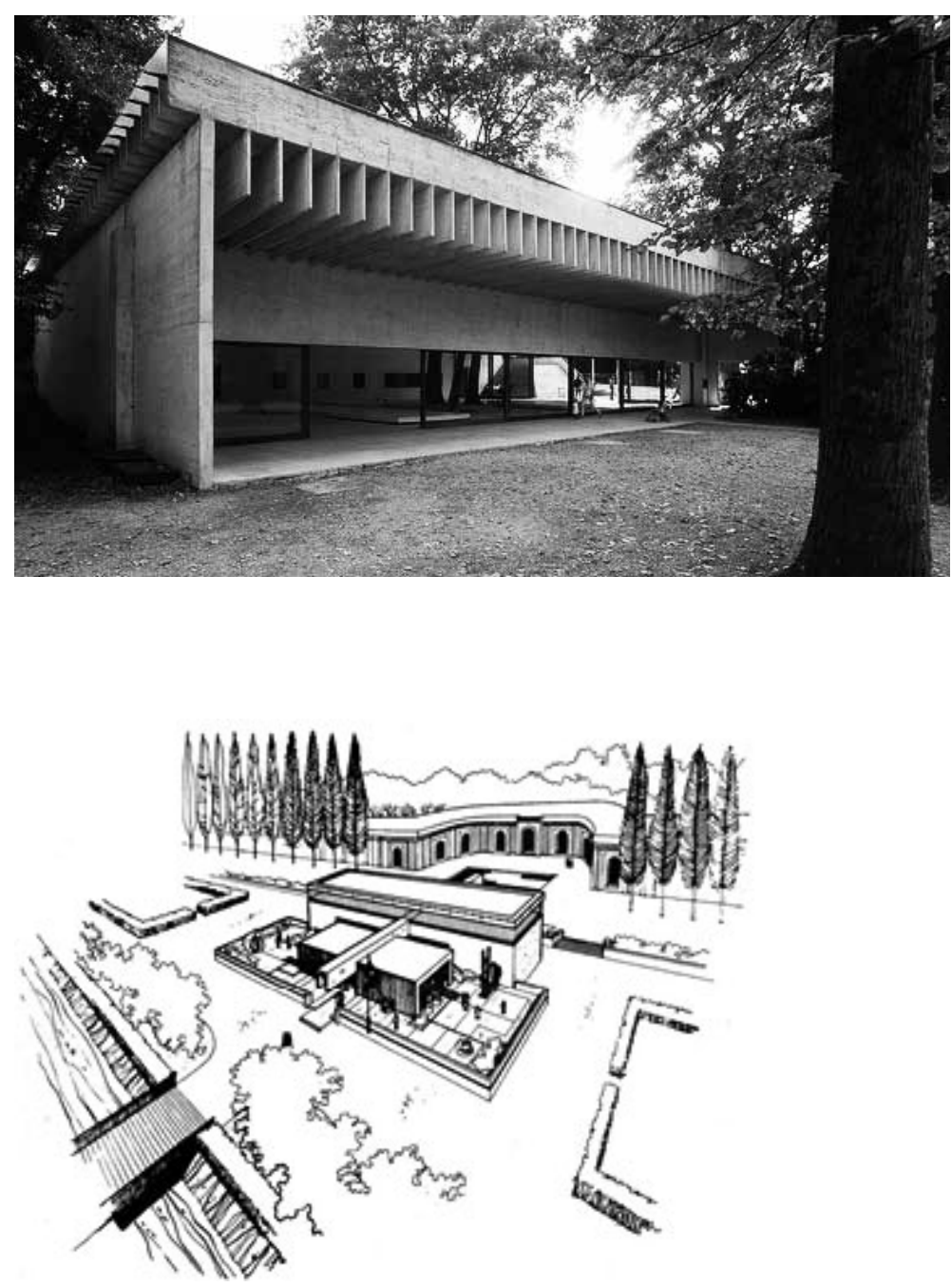

\section{figura 31}

Sverre Fehn. Pavilhão dos Países Nórdicos - 1962

figura 32

Henrique Mindlin e equipe. Implantação do Pavilhão Brasil - 1966 (Giardino, Veneza) 
O Brasil inicia as negociações para edificação de um pavilhão no fim dos anos 50, quando o Giardini já apresentava sinais de saturação e a resposta da equipe brasileira se dá através de uma engenhosa estratégia de implantação. Proposto como ponte de interligação das duas margens do parque cortado pelo canal dei Giardini, o projeto dos arquitetos Henrique Mindlin, Giancarlo Palanti e Walmyr Amaral defendia em seu memorial descritivo o pavilhão ponte e sua arquitetura nada extravagante. Segundo os arquitetos o partido era sóbrio e discreto, e o pavilhão seria elevado do solo 5,00 metros, sobre a ponte existente, propiciando ao longo do passeio pela galeria o descortinar de vistas do parque e da igreja San Pietro di Castello através de duas grandes janelas sobre o canal. O projeto, estrategicamente, também garantia a possibilidade de desmonte e relocação do grande salão de exposição, de 25 por 10 metros, pensado em estrutura metálica pré-fabricada com claraboias na cobertura.

Esta proposta é rejeitada em fevereiro de 1960, e o arquiteto veneziano Amerigo Marchesin, que participara da equipe do projeto original, fica responsável pelo desenvolvimento e construção do novo projeto da equipe de Mindlin (figura 32), que é inaugurado em $1966^{99}$, posicionado poucos metros recuado em relação à margem do rio, mantendo e marcando na fachada o eixo do percurso através de uma viga central que corta o edifício em dois volumes e quatro salões. A implantação de grande força no projeto original, embora polêmica, respeitava o conjunto clássico organizado em torno do jardim configurado pelo longilíneo pavilhão Veneza. Ao compartimentar o grande salão em quatro galerias menores, o novo projeto confere ao corredor central um sentido de passagem sem a mesma interação entre os espaços interno - expositivo - e externo propiciada pelo edifício ponte. Também em função da nova implantação, cria-se um sentido de frente e fundos às fachadas, efeito reforçado pelo pequeno jardim tropical com espelho d'água implantado entre o pavilhão brasileiro e o pavilhão Veneza ao fundo, que elevado do solo por um pequeno

$99 \mathrm{Na}$ Itália a autoria do projeto é atribuída à Amerigo Marchesin, constante colaborador de Carlo Scarpa, no entanto o projeto é publicado na revista Módulo n ${ }^{\circ} 38$, dez. 1964, p. $32-37$ e é também citado por Yves Bruand em "Arquitetura Contemporânea no Brasil" p.256-259, como de autoria do escritório Henrique Mindlin e Associados. Abílio Guerra no artigo "Mostra de Arquitetura na Bienal de 2006" ressalta a participação de Palanti na equipe, que teria tido seu nome omitido por não estar habilitado a exercer a profissão de forma legal no Brasil. <http:// vitruvius.es/revistas/read/arquitextos/07.077/305> 
embasamento que contorna o edifício, evoca a conjunção do terraço e do jardim - tradição italiana - sem qualquer integração com as galerias. Se por um lado reconhecemos um conjunto sóbrio, com escolha de vedos em materiais aparentes - madeira, tijolos e caixilharia em ferro - acabamentos secos e "volumetria com geometria elementar e equilibrada”, que segundo Yves Bruand ${ }^{100}$, tratava-se de uma influência da arquitetura norte-americana - especialmente das recentes obras Mies Van der Rohe naquele país - sobre a obra de Henrique Mindlin. Por outro lado, o legado da arquitetura brasileira na Bienal em seu período de maior projeção internacional com a recente inauguração de Brasília, se vê representada por uma expressão específica da produção deste período muito mais relacionada a um aprimoramento técnico voltado ao mercado.

Outros dois pavilhões nacionais com autoria de arquitetos italianos resultam em experimentos distintos. O projeto de Carlo Scarpa ${ }^{101}$, em 1952, para o pavilhão da Venezuela (figura 33) toponímia que quer dizer pequena Veneza- é uma obra de afirmação de características marcantes, desdobradas posteriormente no trabalho do arquiteto veneziano, especialmente no que diz respeito aos espaços compartimentados e o tratamento de superfícies com diversos detalhes e variado uso de texturas e materiais. Já o pavilhão do Canadá (figura 34), projeto do escritório BBPR ${ }^{102}$ de 1958, atinge o objetivo de criar uma autoimagem simbólica de seu país através do partido arquitetônico ${ }^{103}$, que se desdobra numa cobertura axial espiralada dividida em planos trapezoidais revestidos por painéis leves de madeira industrializada canadense que são apoiados nas suas extremidades em paredes de tijolos aparentes. $\mathrm{O}$ acesso se dá por um pátio resguardado

100 In: BRUAND. Arquitetura Contemporânea no Brasil”, 1991, p.257.

101 Carlo Scarpa também projetou a galeria do livro de arte, em 1950, construção com estrutura de madeira foi destruída por um incêndio no início dos anos 1980, e o jardim de esculturas do pavilhão Itália e a bilheteria da Bienal em 1952.

102 Escritório italiano essencial no processo de modernização da arquitetura italiana que é reconhecido pelos projetos de memoriais e pavilhões no segundo pós-guerra além da marcante Torre Velasca em Milão.

103 Dino Damburo é um arquiteto canadense dedicado ao estudo da preservação do patrimônio arquitetônico que atualmente preside o ICOMOS do Canadá, órgão da UNESCO dedicado à preservação de monumentos e é autor do artigo integrante da instalação Common Pavilions na $13^{\circ}$ Bienal de arquitetura de Veneza onde defende a tese de que o pavilhão, embora projetado por um escritório estrangeiro, explicita aspectos essenciais dos desafios canadenses ao estabelecer uma relação entre natureza e construção. <http://www.commonpavilions.com/ pavilion-canada.html> 

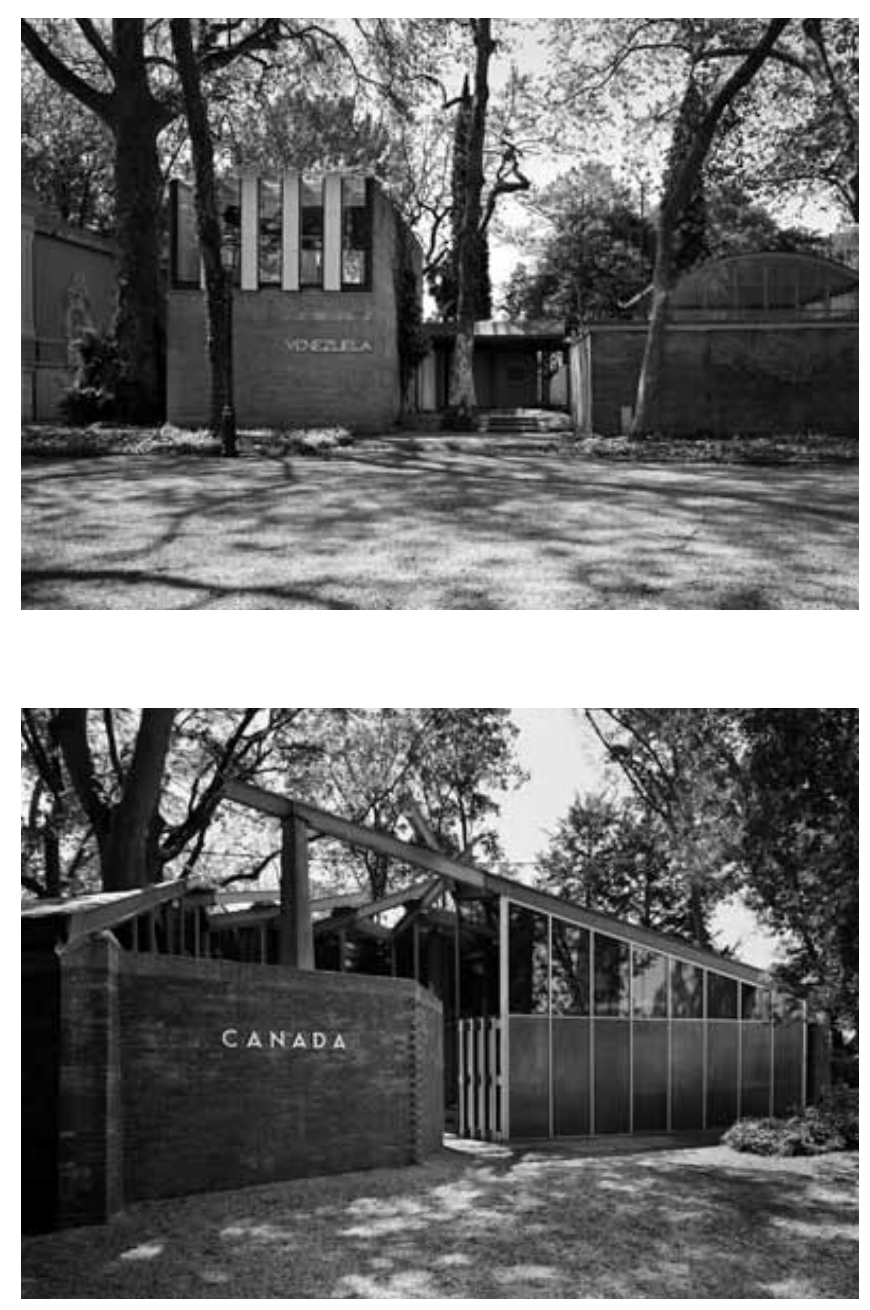

figura 33

Carlo Scarpa. Pavilhão Venezuela - 1952

figura 34

BBPR Pavilhão Canadá - 1958

(Giardino, Veneza) 
- destinado, segundo o projeto, à exposição de esculturas - e integrado ao interior por grandes panos envidraçados, assim como a árvore que é mantida no interior do salão.

Os últimos pavilhões nacionais construídos no parque são o da Austrália e da Coréia. O primeiro foi projetado por Phillip Cox, com grande preocupação em relação a seu escalonamento e acomodação no terreno, adequando-se às arvores existentes com salões de diferentes proporções - um longo, estreito e mais baixo, com um balcão que avança sobre outro grande salão de pé-direito alto - e promovem vistas ao aproximar o público do ambiente externo através de suas varandas - uma na entrada e outra com vista para o canal. Pré-fabricado em aço no seu país de origem, com telhados curvos representativos da arquitetura australiana da década 70 e sua necessidade de romper com a tradição inglesa, o pavilhão foi montado e inaugurado em 1987 e deverá ser substituído por outro projeto em 2015 atestando sua importância como depoimento de um momento específico da arquitetura de seu país. O segundo é projeto de Seok Chul Kim, implantado em 1996, aproveitando e adequando uma edificação em tijolos pré-existente que é envolvida pela nova estrutura metálica.

Chama a atenção do visitante do Giardino, especialmente durante as Bienais de Arquitetura, a coleção de edifícios resultante destes anos de sucessivas construções que fizeram do parque um canteiro de obras constante, ao lado de uma cidade consolidada, patrimônio da humanidade, onde o papel da arquitetura está circunscrito ao restauro e à requalificação de edifícios tombados. $\mathrm{Na}$ pequena área do parque, um enclave é posto, uma exposição à parte e per se, acontece para além das curtas ocasiões em que anualmente os pavilhões estão ocupados.

“A exposição em si tem uma estrutura e, consequentemente, uma mensagem, tanto quanto a arte que mostra. Aqui podemos abordar a arquitetura como um modelo de comunicação não verbal, um pouco como uma exposição." 104

Estas arquiteturas de uso descontinuado, cubos brancos ou não,

104 "The exhibition itself has a structure and hence a message, as much as the art it shows. Here we can approach the architecture as a model of a nonverbal comunication, somewhat like an exhibition."In: ALLOWAY, Lawrence. The Venice Biennale 1895-1968. From salon to goldfish bowl. 1968, p.18. 
deixam de ser vistas apenas como galerias com função restrita de suporte expositivo ou como ensaios de museus em pequena escala e impõem sua espacialidade como desafio a sua ocupação, estimulando a interação entre conteúdo e continente arquitetônico, provocando intervenções de grande potência que desdobram uma produção de interesse para a interação entre arte e arquitetura.

Liane Lefaivre interpreta que grande parte da produção apresentada na $51^{\circ}$ edição da Bienal de Arte de Veneza (2005) marca a expansão de uma meta-arquitetura ${ }^{105}$, ou seja, um aumento de interesse das artes visuais sobre a arquitetura, possivelmente estimulada pela "inegável fase de esplendor formal, apesar de seu estancamento ecológico e social" e pela constatação, "pós 11-de setembro, do enorme potencial simbólico da arquitetura sobre qualquer outro meio" ${ }^{106}$.

Por um lado foi possível acompanhar e reconhecer ao longo dos anos 60 o desmantelamento das categorias tradicionais - gravura, pintura e escultura - e a dilatação do caráter "ambiental" culminando com a meta-arquitetura. Por outro lado, este estreitamento de fronteira é ampliado pela formalização cada vez mais escultórica da arquitetura contemporânea. No caso dos pavilhões de Veneza, este estreitamento se expressa especialmente numa intensificação do diálogo entre obra e espaço expositivo nas Bienais e exposições de arquitetura, ampliado pelo destaque que se dá a uma relação espacial tomada como matéria essencial do raciocínio arquitetônico.

A convergência dos pavilhões nacionais do Giardino, arquiteturas caracterizadas pelo seu caráter simbólico com programa reduzido relacionado à noção de galeria, quando somada às experimentações expositivas das representações nacionais - agora também estimuladas pelas curadorias das bienais de arquitetura de Veneza -, faz com que tornem-se dispositivos espaciais deixando-se vestir e transformar a cada exposição.

105 Além das obras de Dan Graham e Hans Schabus, já tratadas nesta dissertação, a mostra apresentou, entre outras meta-arquiteturas, os trabalhos de: Rachel Whiteread "Basement" 2000-2002; Erwin Wurm "Guggenhein Melting” (2004); e Ed Ruscha com a serie "Blue Collar" (1992) e "The Od Bulding" (2004).

106 “Arte arquitetectónico, Uma nueva tendência em la Bienal de Venecia." In: Arquitectura Viva, 102, p. 89. 


\title{
3.2 Atmosfera e Instalação
}

\author{
"Penso que uma parede não é um lugar \\ para pendurar uma foto ou uma pintura - é um \\ componente chave do espaço, e talvez seja por \\ isso, que salas tenham sido interpretadas por \\ algumas pessoas como instalações artísticas. Mas \\ isso, na verdade, é uma aproximação bastante \\ arquitetônica." 107
}

A XII Bienal de Arquitetura de Veneza, em 2010, teve como curadora a arquiteta Kazuyo Sejima que elegeu o título "People meet in architecture" como forma de se reconsiderar o potencial da arquitetura na sociedade contemporânea e estimulou, através da seleção de participantes e propostas, a conformação de uma exposição que pudesse ter sua própria linguagem, distribuindo aos participantes um espaço para ser interpretado e usado como meio de expressão de raciocínios, uma vez que, segundo a arquiteta, ao contrário da arte que mostra a si mesmo, nas bienais de arquitetura é preciso que se encare o fato de que a arquitetura é impossível de se mostrar. Assim, Sejima convida seu parceiro no escritório SANAA, Ryue Nichizawa, para trabalhar como consultor artístico numa exposição que procurou gerar "atmosferas".

“Atmosfera" traz implícito em seu significado uma miríade de condições que lançam possibilidades de interpretação. Pode ser entendido como efeito visual, embora favoreça uma imersão sensorial. Pode ser também pensado numa chave lógica de organização ou uma relação programática que agencia uma interação entre o físico e o social, e, no seu sentido mais literal, remete a um efeito que se dá num

107 "I think that the wall is not a place to put a picture or a painting - it is a key part of the space and perhaps this is why the rooms have been interpreted by some people as artistic installations. But this is actually a very architectural approach." SEJIMA, apud MOSTAFAVI. 2010 ,p. 8. 
transcurso temporal, uma densidade que proporciona efeitos de luz pelas propriedades do ar gerando fenômenos de refração e reflexão que borram a realidade.

Segundo Eve Blau, no texto "Agency in Atmosphere" escrito para o catálogo da exposição, ao mesmo tempo em que "atmosferas" distanciam o trabalho do arquiteto pelo viés da obra experimental - revelada quase como um trabalho científico, onde hipóteses são lançadas -, por outro lado revelam a tendência destas arquiteturas ganharem contornos críticos ao se alinharem a boa parte da produção artística, uma vez que seus resultados são em grande parte imprevisíveis. Portanto, a produção apresentada nesta bienal resulta de processos colaborativos entre arquitetos, artistas e engenheiros, o que segundo a curadora Sejima, não se trata de grande novidade, uma vez que o papel de reunir e compatibilizar estas ações, tendo o espaço como meio, sempre foi uma aproximação arquitetônica ${ }^{108}$. Logo, é clara aproximação dos termos: "atmosfera" como um equivalente daquilo que se reconhece como "instalação" nas artes visuais.

Sejima parece de fato catalisar uma tendência já observada nas edições anteriores em projetos como o "Hormonorium" 109 (figura 35), apresentado no pavilhão da Suíça, na VIII Bienal de Arquitetura de Veneza (2002), pelos arquitetos Décosterd \& Rahm, dupla que orienta sua produção segundo fenômenos naturais como pressão, digestão, convecção e radiação, etc... Em um dos salões do pavilhão suíço, um retângulo de aproximadamente dez por trinta metros abrigava uma estrutura de plexiglass que permitia ao espectador caminhar sobre quinhentas e vinte oito lâmpadas fluorescentes instaladas no chão, simulando um clima alpino a partir da emissão de luz como se fosse o reflexo do sol na neve. As fronteiras físicas entre espaço e organismo vão além dos sistemas métricos e visuais, e estabeleciam uma conexão entre a influência do ambiente no organismo, criando uma síntese orgânica entre humor e espaço, reduzindo a fatiga e aumentando o

108 In: "A covensation with Kazuyo Sejima \& Ryue Nishizawa". Moshen Mostafavi, El Croquis $\mathrm{n}^{\circ} 155$, p.7.

109 O Memorial descritivo e imagens do projeto estão disponíveis no site de Phillipe Rahm: <http://www.philipperahm.com/data/projects/hormonorium/index.html > consultado em $12-01 / 2011$. 

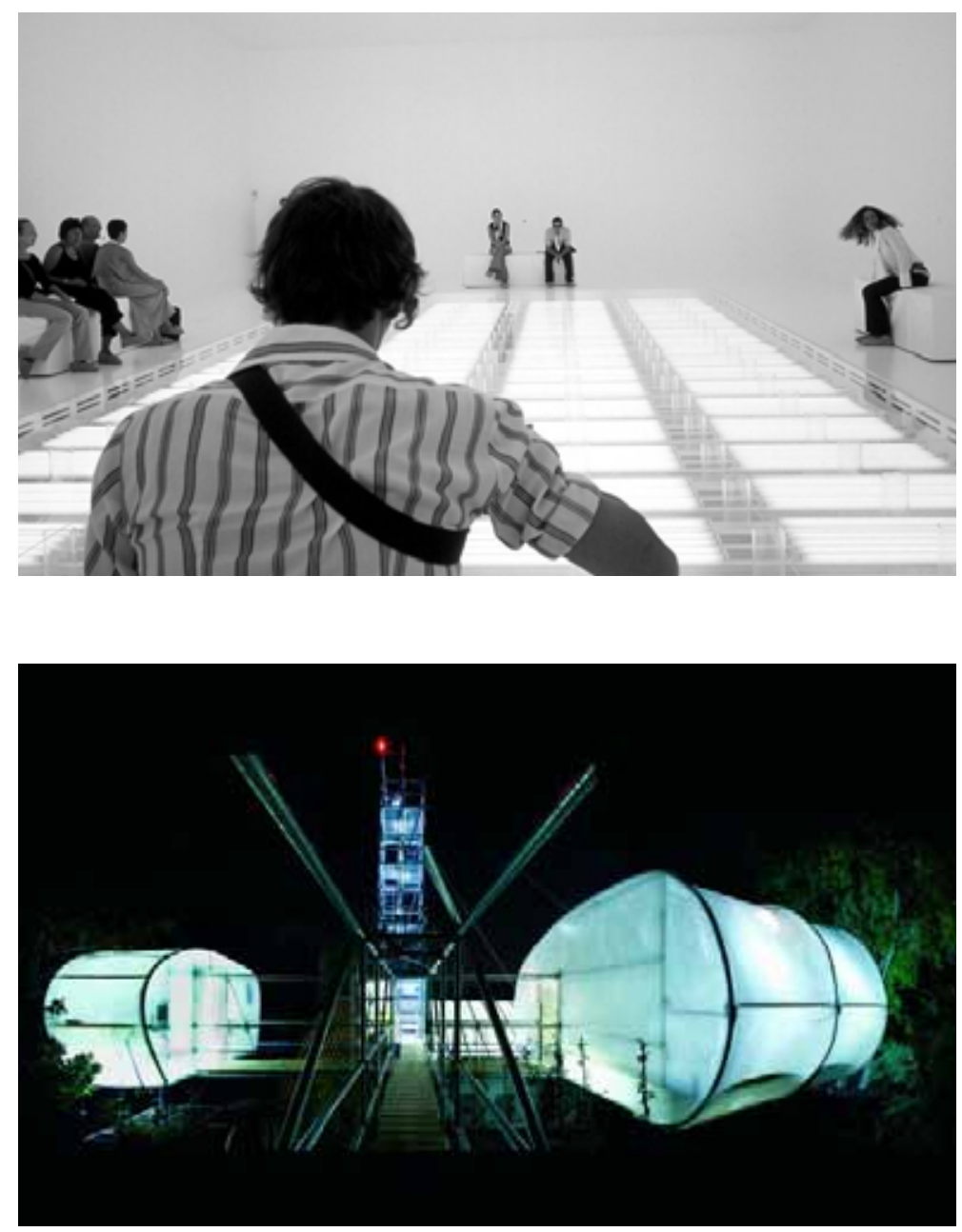

\section{figura 35}

Décosterd \& Rahm. "Hormonorium”, Pavilhão Suíça - 2002 figura 36

Patrick Bouchain. "Metavilla”, Pavilhão França - 2006

(Giardino,Veneza) 
desejo sexual pela emissão de raios UV-A que bronzeiam a pele, e UV-B que sintetizam vitamina D. Os níveis de oxigênio no ar foram rebaixados de forma a produzir uma leve euforia e confusão e um aumentar o ritmo cardíaco, como se o espectador estivesse a três mil metros de altitude. Ao questionarem a materialidade, Décosterd \& Rahm exageram os efeitos possíveis de uma arquitetura focada nas possibilidades de reflexo do espaço no sujeito e com isso aproximamse de operações similares experimentadas pela arte e sua proposta de revisão da própria disciplina. Esta aproximação fisiológica levada ao extremo também remete ao entendimento de campo ampliando arquitetônico proposto por Anthony Vidler, onde a partir da oposição entre os campos da arquitetura e da biologia - seja pelas teorias de Ryner Banham nos anos sessenta ou pelas expectativas de uma bioforma prevista por Charles Jencks no seu quadro de movimentos arquitetônicos - seria possível o desdobramento de um entendimento espacial que rompesse com os dualismos problemáticos entre forma e função, utopia e realidade, estrutura e vedação ou historicismo e abstração ${ }^{110}$.

Outro exemplo de instalação é a já citada "Metavilla" (imagem 36), na X Bienal de Arquitetura de Veneza, em 2006, que opera em sintonia com o que foi agrupado por Nicolas Bourriaud sob o termo “estética relacional”. O arquiteto Patrick Bouchain, reconhecido por desenhar situações, ou seja, articular interesses de forma a ativar os espaços como locais de convivência, propõe uma ocupação do pavilhão francês a partir de uma enorme estrutura de andaime, sem disfarces ou acabamentos que buscassem um resultado estético, com vedos simples de tecidos e madeira pensados para durar o tempo do evento. O volume da construção extrapolava o do pavilhão e abrigava todo o programa de uma grande habitação coletiva contemplando todas as necessidades básicas: cabines dormitórios - como um pequeno edifício verticalizado dentro do edifício -, espaços coletivos de estar, escritório e cozinha, bar e ainda um terraço-jardim com piscina e sauna.

110 Estes dualismos são levantados como questões disciplinares atávicas que necessariamente precisam ser superadas para a uma reconstrução do campo disciplinar arquitetônico no texto de Anthony Vidler: Architecture's Expanded Field, de 2004, já comentado no primeiro capítulo desta dissertação. 
Quarenta pessoas viveram de fato dentro do pavilhão coexistindo com a rotina de visitação e interagindo com o público através de uma intensa programação de conferências, atividades e refeições. Assim como nas obras do artista Rirkrit Tiravanija - que em algumas de suas obras proporciona acontecimentos em torno de refeições preparadas por ele dentro da galeria - o que ocorre é uma quebra de estatuto, um espaço que passa a ser apreendido não apenas na sua materialidade, mas no seu tempo de experimentação e nas relações de convívio. De acordo com o texto manifesto, do grupo EXYZT ${ }^{111}$, o que se propôs foi uma subversão do palácio expositivo através de um evento:

\begin{abstract}
"Este evento está para a exposição clássica de arquitetura como a implementação está para um conceito. O público pode experimentar o projeto de arquitetura exposto aqui, e, particularmente, avaliar o ideal prático apresentado, não apenas como uma teoria utópica, mas como uma ação concreta que precisa ser executada. Ao ocupar este pavilhão nacional emancipado, abrindo-o ao público desta maneira singular, um ato arquitetural esta sendo realizado. Provavelmente o único ato do gênero que pode ser realizado nestes tempos de insegurança e oculta tensão de guerra. O acolhimento aos desconhecidos, o implacável outro, é mais do que nunca um ato relevante. Felizmente a prazerosa cidade exibida no pavilhão existe de fato, aqui e em qualquer outro lugar. Esta exposição é apenas um indicador." 112
\end{abstract}

\footnotetext{
111 Nome do grupo que habitou a "Metavilla". Foneticamente esta corruptela corresponde à palavra existence que significa existência, em inglês.

112 "...This event is to a classic architectural exhibition what implementation is to a concept. The public can experience the architectural design displayed there, and particularly assess the practical ideal being presented, not just as a utopian theory but as a concrete action that needs to be accomplished. In occupying this national emancipated pavilion and opening it up to the public in this unusual way, an architectural act is being performed. Probably the only such act that can be made in these times of insecurity and underlying tensions of war. The welcome of strangers, implacably "other", is more than ever a relevant act. Happily the joyful city on show in the pavilion really does exist, here and elsewhere. This exhibition is just a pointer." Disponível em: $<$ http:// itsafunnyoldworld.wordpress.com/tag/metavilla/ > consultado em 28/11/2012.
} 
Como último exemplo, "Re-Set" apresentado na XIII Bienal de Arquitetura (2012), demonstra que a tendência instalativa persiste mesmo sob a orientação de uma curadoria considerada conservadora como a de David Chipperfield. A designer holandesa, que fundou seu escritório, o Inside Outside em 1991, propôs para o pavilhão holandês, sob curadoria de Ole Bouman, diretor do NAi - Netherlands Architecture Institute - a instalação de uma cortina. Blaisse é reconhecida por seu trabalho de paisagismo e design têxtil, especialmente pelas obras em colaboração com o arquiteto Rem Koolhaas, com quem desenvolveu o desenho de cortinas e tapetes - elementos normalmente tidos como mera solução decorativa e supérflua que ganham grande importância por sua demanda técnica em projetos como a Biblioteca de Seattle, de 2004, ou a casa da Música do Porto, de 2005. Estas intervenções são elaboradas em equipe desde a concepção do projeto, considerando uma análise cuidadosa das soluções desejadas e elaborando os pontos de vista, a dosagem de luz, a acústica e a reflexão do som, as relações cromáticas, a sensação de escala e as definições de percursos e experiências possíveis pela alteração da percepção espacial a partir da introdução destes elementos. O processo de colaboração imbricado entre design e arquitetura, desde as origens do projeto, reporta a outras parcerias históricas como a de Charlotte Perriand e Le Corbusier e especialmente a de Mies Van der Rohe e Lilly Reich, designer ligada ao Deutscher Werkbund ${ }^{114}$ e colaboradora do arquiteto alemão, que assim como Blaisse, contribuiu com a instalação de cortinas capazes de transformar por completo os ambientes projetados por Mies, especialmente no projeto do "Velvet and Silk Café" (figura 38) para exposição de moda de 1927, em Berlim, e para o Pavilhão de Barcelona, em 1929, onde a cortina vermelha além de completar a almejada paleta cromática da bandeira alemã, atua como

113 Palavra inglesa que significa reestabelecer, recompor e, ao ser destacada de seu prefixo, reforça também o sentido da palavra set como receptor.

114 O Deutscher Werkbund (Federação Alemã de Trabalho) foi um esforço do Estado alemão no sentido de promover a associação entre artistas, arquitetos, designers e a Indústria objetivando uma parceria entre fabricantes de produtos e profissionais para aprimorar e aumentar a competitividade da Indústria alemã no mercado internacional. O Werkbund tem importante papel no desenvolvimento da arquitetura moderna e o desenho industrial influenciando posteriormente a criação da Bauhaus. 

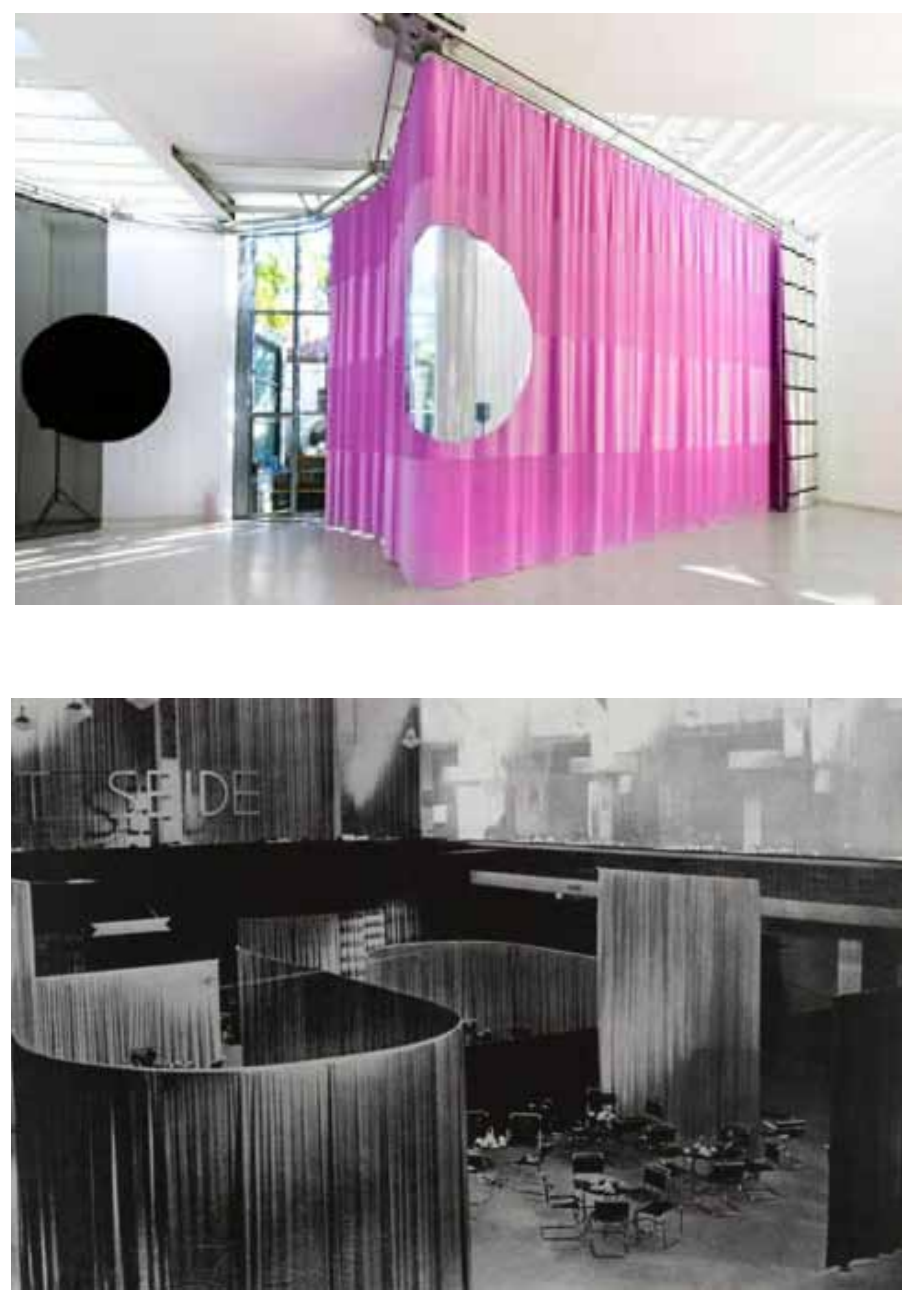

\section{figura 37}

Petra Blaisse. Re-set, Pavilhão Holanda - 2012

(Giardino, Veneza)

\section{figura 38}

Mies Van der Rohe e Lilly Reich. Velvet and Silk Café - 1927

(Berlim) 
elemento teatral com sua superfície opaca que emoldura e configura o salão interno.

Para o pavilhão de Ritveld em Veneza, a intenção da curadoria era retomar o assunto tratado na edição anterior da bienal e explicitar a importância de ações capazes de ativar espaços ociosos, revelando todo o potencial do edifício que permanece vazio na maior parte do tempo ${ }^{115} \mathrm{e}$, assim, estabelecer um paralelo necessário quanto às políticas que priorizam o avanço da construção e da especulação imobiliária na Holanda, quando, através de outras ações, seria possível uma transformação pela mudança de usos, revisão e reaproveitamento de estruturas já existentes. Através da instalação de um elemento simples, uma cortina, Blaisse buscou revelar a experiência espacial do edifício vazio e demonstrar a força do gesto arquitetônico como capaz de dar nova vida a um lugar. Uma estrutura com esteira dupla fixada no teto pavilhão foi programada para arrastar a cortina para doze posições diferentes, a cada cinco minutos, criando diferentes recintos e alterando a percepção espacial do local ao longo do dia, tanto pela sobreposição de camadas de texturas, cores, transparência e opacidade como provocando um sentido visual da passagem do tempo, como que provocando o público a esperar um acontecimento que se dará quando as cortinas forem abertas, e os atores entrarem em cena. Mas o que de fato se revela é uma nova reconfiguração do espaço vazio onde a cortina é o elemento de cena e o espaço do pavilhão de Rietveld, a estrela do espetáculo.

Assim, o desejo manifesto de Sejima, de organizar uma exposição onde cada arquiteto seria responsável e curador de sua própria exposição, pulverizando a noção de autoria da curadora e destacando o espaço como meio de expressão do pensamento arquitetônico, atinge com precisão seu objetivo. Ao gerar uma multiplicidade de pontos de vista e processos colaborativos em torno de "atmosferas" onde "pessoas se encontram", Sejima consolida a tendência, já observada ao longo das Bienais de Arquitetura de Veneza, desde sua origem em 1980, do uso do espaço e dos pavilhões nacionais como potentes campos discursivos

115 Um levantamento realizado pelos holandeses revela que, dos 58 anos de existência do pavilhão, este permaneceu vazio por 40 anos. 
e críticos através de instalações acionadas pela presença do público.

Embora a curadoria dos pavilhões do Giardino seja de responsabilidade das representações nacionais, a separação entre os espaços físicos da exposição não chega a gerar uma cisão conceitual de fato. No edifício do Arsenale e no pavilhão La Biennale se desenvolve a "tese curatorial”, acomodada de forma contínua nos diversos recintos que se sucedem linearmente de acordo com as características destes dois edifícios, enquanto nos pavilhões do Giardino. O tema também é acolhido e elaborado de acordo com o contexto das representações nacionais e, da mesma forma, como resultado, instalações são propostas.

São bons exemplos, na edição de 2010, o Pavilhão da Coreia que recria uma hanok, casa tradicional coreana encravada no interior do pavilhão proporcionando um entendimento do modo de vida tradicional em meio à cidade de Seul em rápida transformação, ou o pavilhão da Romênia, que posiciona uma segunda construção dentro do pavilhão de forma a exibir a tensão entre espaço público e privado através da inserção de um volume de precisos $94,4 \mathrm{~m}^{2}$, onde, apenas uma pessoa por vez experimentava o espaço privado com a densidade demográfica de Bucareste, um quarto fechado com apenas uma abertura no teto para entrada de luz, enquanto o público se aglutinava na fila que envolvia o volume podendo apenas observar, através de alguns pequenos óculum, a relação de isolamento que estavam prestes a vivenciar.

Além destes dois principais ambientes expositivos, Sejima propõe um terceiro que permanece como um legado à Bienal, uma vez que foi retomado e ocupado por algumas estruturas na edição de 2012 - de curadoria de David Chiperfield - configurando um importante enclave para a discussão pavilionar em contraponto aos pavilhões permanentes do consolidado Giardini. O Giardini delle Virgine surge como proposta de transposição do conceito de atmosfera para a paisagem por parte do holandês Piet Oudolf e culminam na expansão da instalação de dentro dos espaços expositivos para o edifício relacionado ao jardim. Implantado no fim do longíssimo edifício do Arsenale, próximo ao canal de acesso ao antigo edifício estaleiro, na XIII edição os arquitetos 
portugueses Eduardo Souto de Moura e Álvaro Siza foram convidados a projetar estruturas temporárias neste jardim, assim como Aires Matheus no espaço aberto que o antecede.

As três estruturas têm em comum a proposta de percursos que descortinam relações entre objeto construído e enquadramentos, atualizando a presença do espectador. Estes pavilhões se colocam como corpos estranhos que destacam e revelam o entorno num gesto onde cada arquiteto, a sua maneira, experimenta procedimentos escultóricos afeitos a sua prática arquitetônica gerando, como resultado, estruturas que não possuem sequer a função de abrigo, uma vez que são estruturadas como coberturas.

Siza cria duas sequências de paredes - pintadas de um vermelhoterracota característico das construções italianas - que pela angulação de sua implantação ora se aproximam, ora se distanciam, criando percursos que modificam as relações com as árvores existentes agregadas aos recintos. Como resultado deste procedimento, ambientes se conformam e remetem às ruas e percursos por vezes labirínticos de Veneza, gerando uma estrutura voltada para seu interior com aparência robusta marcada por grande volume em balanço que indica sua saída. (figuras 39 e 40)

Souto de Moura cria um percurso linear paralelo ao limite entre o terreno construído e retificado do canal, onde desenvolve uma série de três ambientes de escalas e proporções diversas que oferecem, através de suas janelas angulares emolduradas por linhas desenhadas por um leve perfil metálico preto, um olhar para o canal gerando uma construção que se assemelha a uma fortificação cor de areia, enquadrando vistas da outra margem, marcando a ocupação de um terreno e uma geografia transformada pelo desejo humano ${ }^{116}$ (figura 41 e 42). Siza Vieira e Souto de Moura trabalham o contexto de forma diferente, um coloca-se à margem do canal e projeta o olhar para fora enquanto o outro, implantado em meio ao jardim, submete o espectador a uma sensação de interiorização. Por último, Aires

116 A geografia de Veneza é resultado de sucessivas transformações e avanços de território sobre a água, sendo que a ilha que deu origem à cidade é hoje irreconhecível em seu traçado original. 
Mateus desenvolve "Radix", uma peça que resulta formalmente de um procedimento (figura 43 e 44 ) de extrusão de uma esfera em um cubo executado em cortem, onde os vazios resultantes do processo geram cúpulas e arcos, e revelam, pela permanência de algumas arestas, a forma cúbica original, completa pelo olhar, e três pontos de apoio que tocam o solo, uma delas pontiaguda revelando a contraposição entre o peso superior e vazios resultantes na proximidade do contato com o solo e no balanço sobre o canal, estabelecendo uma relação de sobreposição de vistas e formas entre o edifício do Arsenale e a peça escultórica.

Os procedimentos projetuais e a pesquisa espacial destes arquitetos são transpostos para estes pavilhões que têm em comum a total ausência de programa, a proximidade com um ensaio escultórico como um grande modelo em escala 1:1, a despreocupação com o aspecto do abrigo, a intenção de proporcionar ao espectador uma experiência corporal, onde materiais e cores são aplicados e testados, transformando o espaço circundante de implantação que é ressignificado e colocado em foco partir da inserção dessas arquiteturas. 

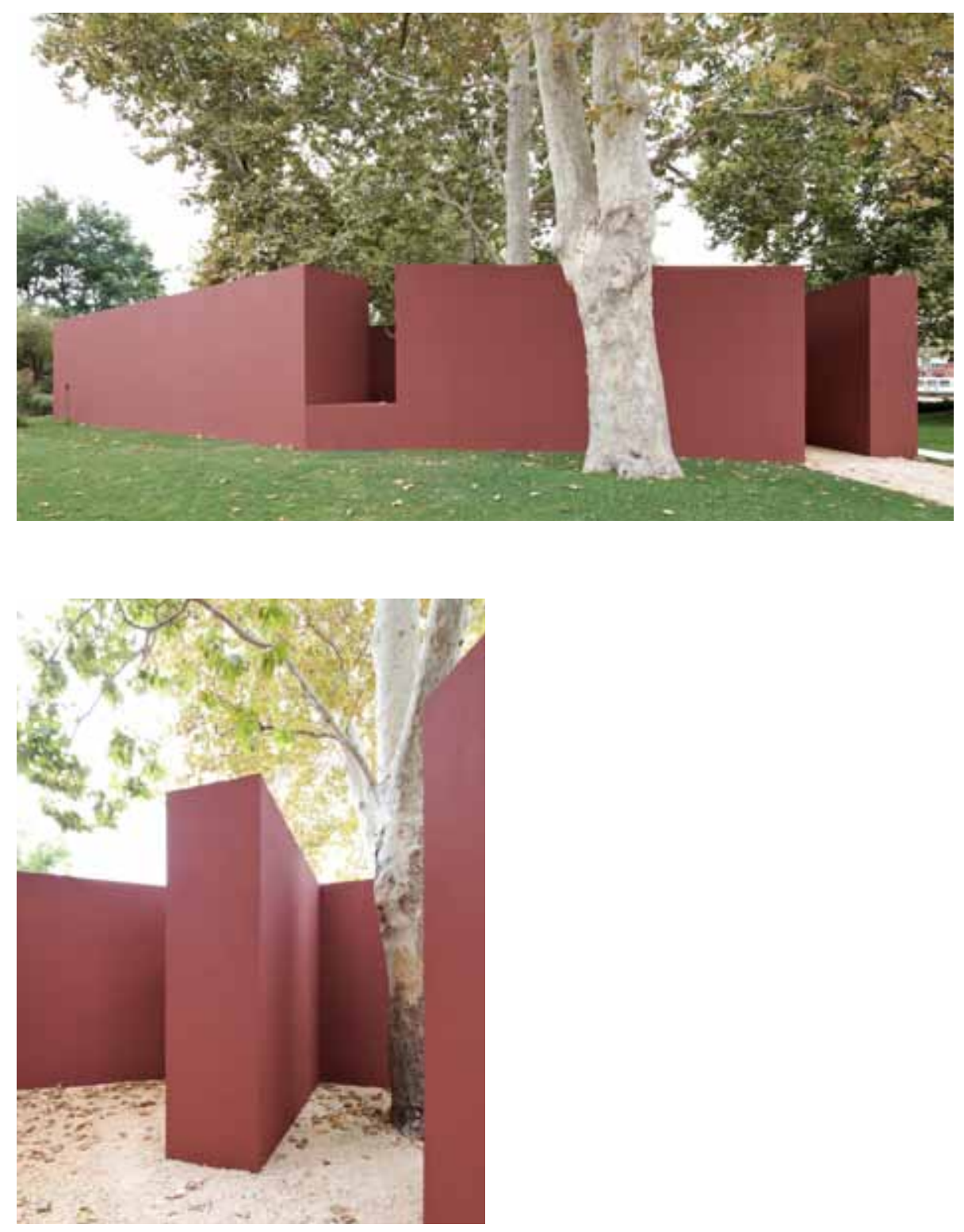

figuras 39 e 40

Siza Vieira. Pavilhão para a Bienal de Veneza - 2012

(Giardini delle Virgine, Arsenale, Veneza) 


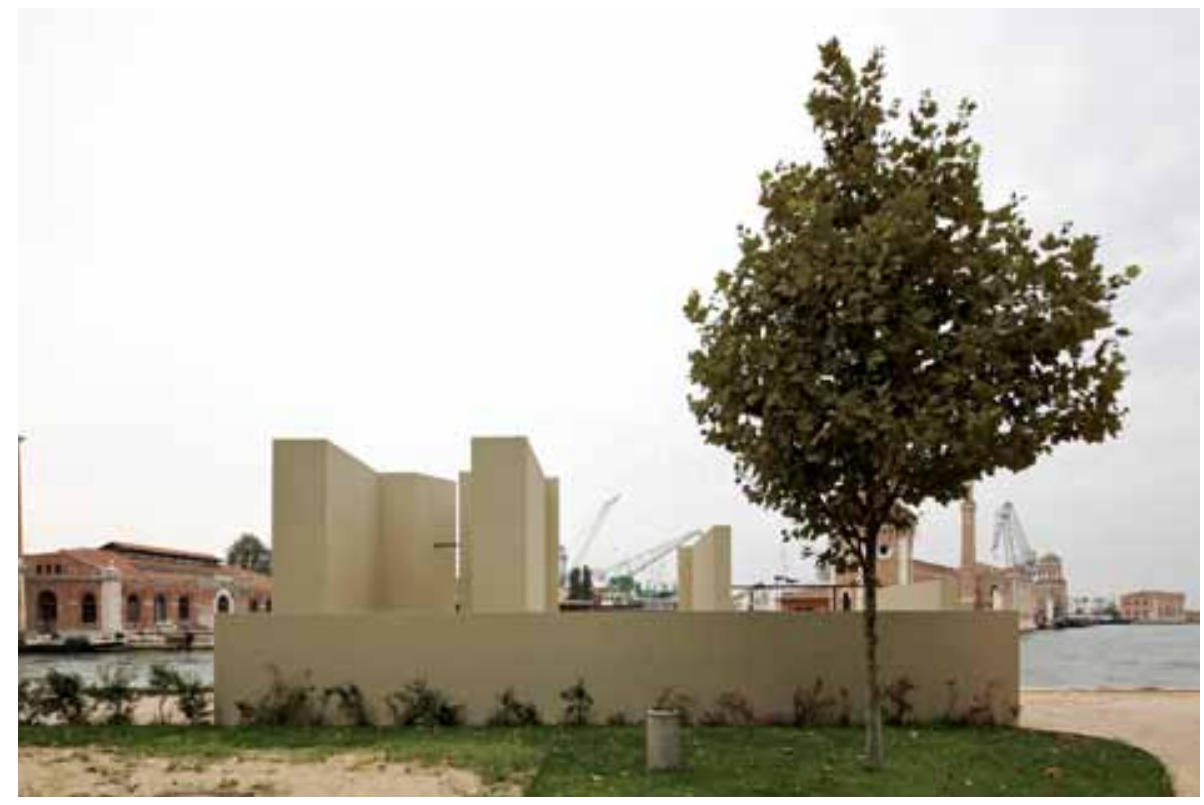

\section{figura 41}

Eduardo Souto de Moura. Pavilhão para a Bienal de Veneza - 2012

(Giardini delle Virgine, Arsenale, Veneza) 

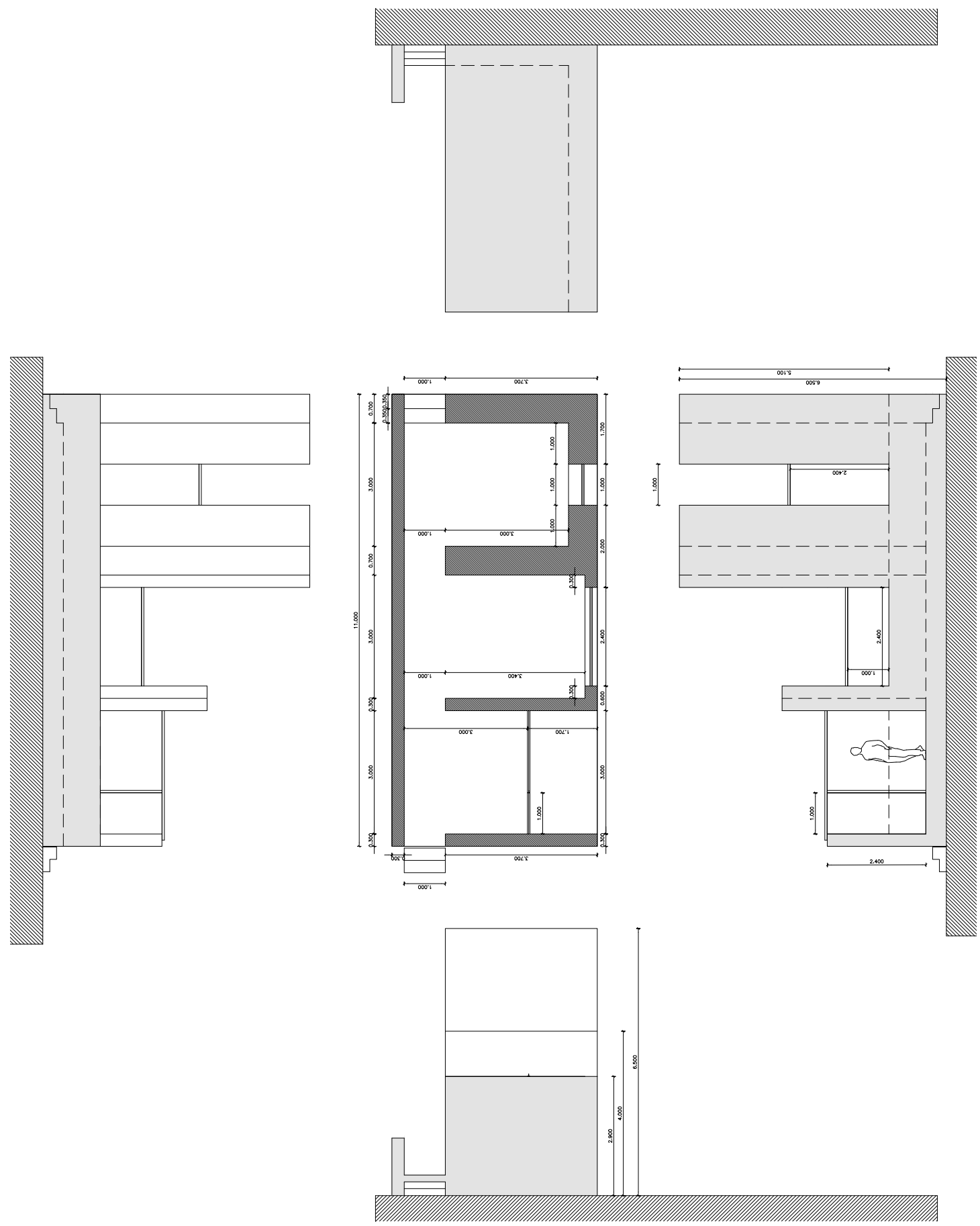

figura 42

Eduardo Souto de Moura.

Projeto para o Pavilhão para a Bienal de Veneza - 2012

(Giardini delle Virgine, Arsenale, Veneza) 


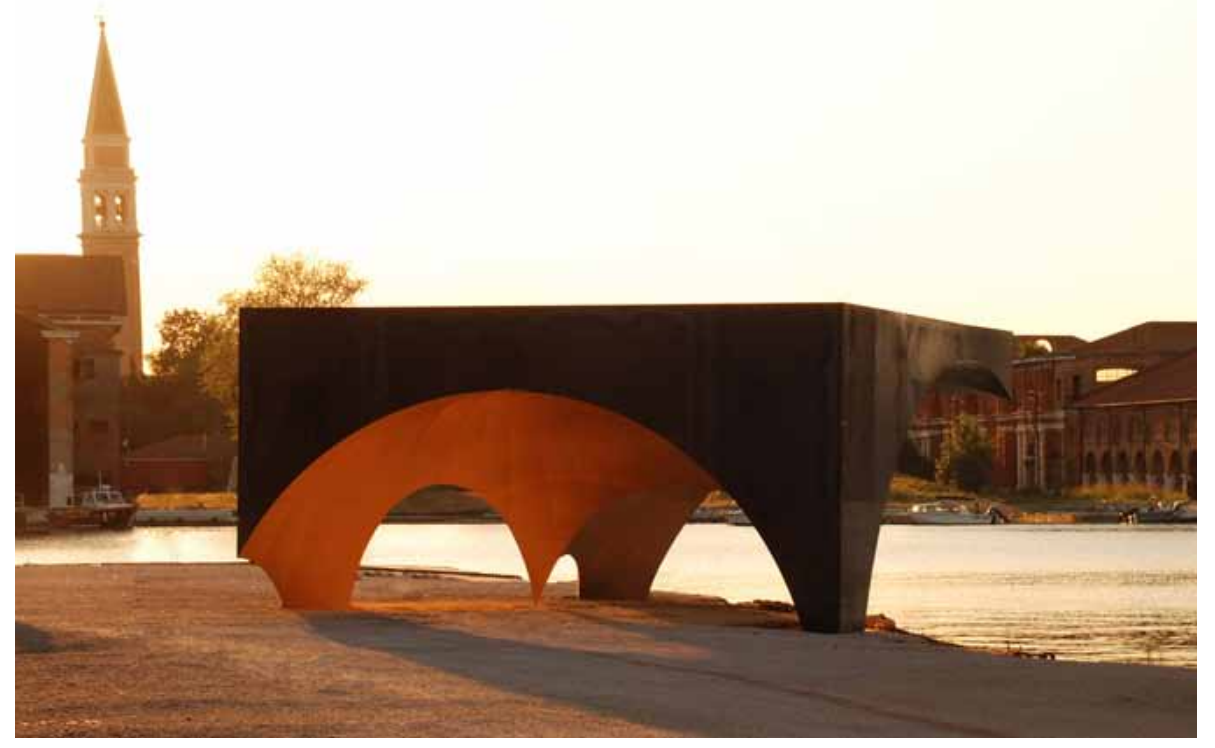

\section{figura 43}

Aires Matheus. Radix - 2012

(Arsenale, Veneza) 

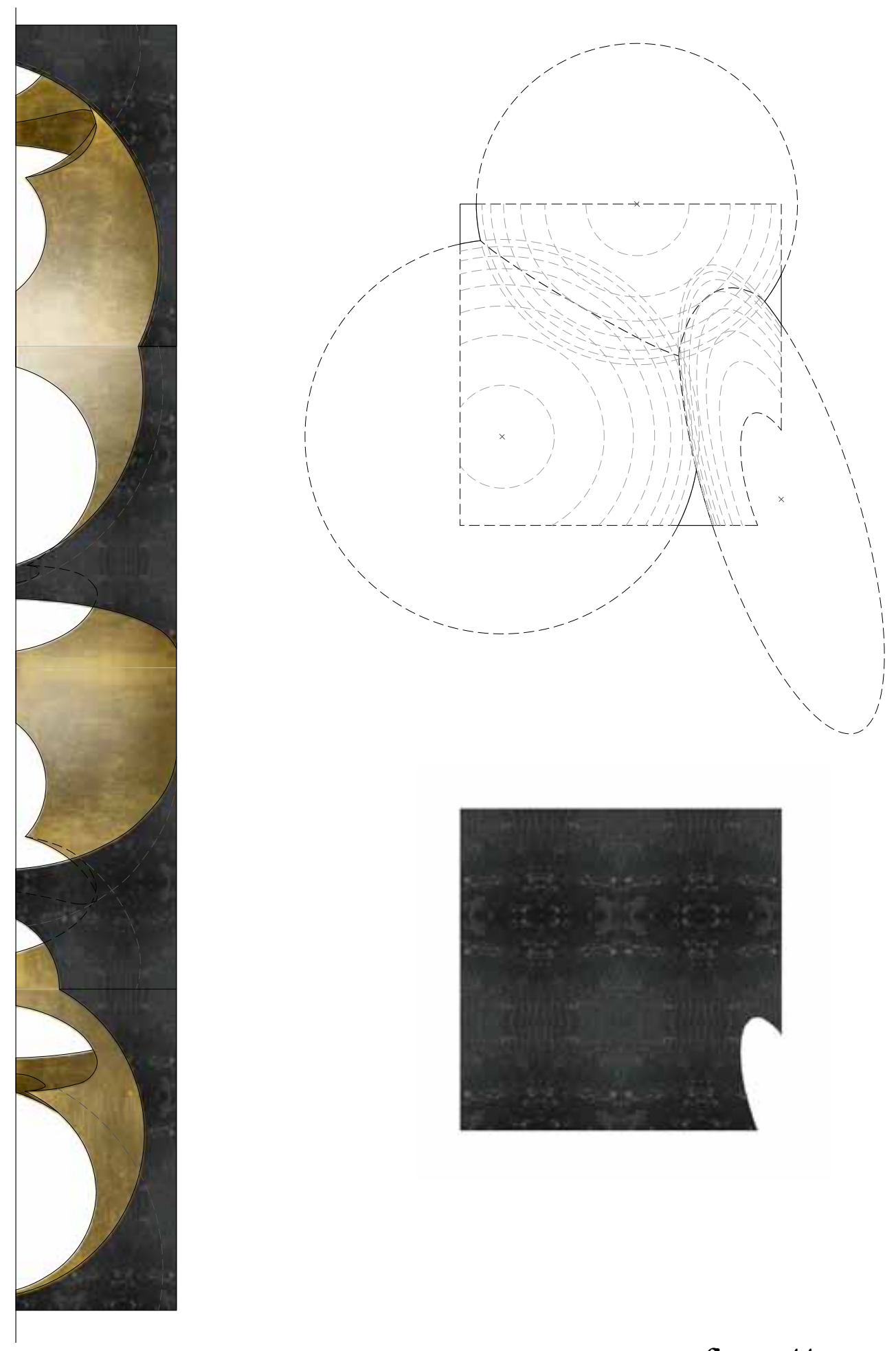

figura 44

Aires Matheus. Projeto para Radix - 2012

(Arsenale, Veneza) 


\title{
3.3 A Bienal de 1980 e o Teatro Del Mondo.
}

\author{
“É no seu fazer, através da combinação \\ de suas múltiplas expressões - o texto, desenho, \\ o edifício - que a arquitetura produz e manifesta \\ o seu pensamento." 117
}

Giuseppe Galasso, então presidente da bienal, identifica um conflito de interesses entre arquitetos e artistas como razão para a criação de um evento dedicado de forma autônoma à arquitetura no texto de apresentação do catálogo da primeira mostra internacional de arquitetura de Veneza, em 1980. As transformações das artes, abandonando as categorias tradicionais com a explosão do suporte artístico, teria relegado ao arquiteto o papel de mero mediador dos fatos artísticos, rebaixando o espaço e a importância das latentes discussões no sentido de uma revisão das premissas arquitetônicas modernas desgastadas desde o segundo pós-guerra, e das múltiplas respostas compostas aos problemas arquitetônicos em curso. Nomeado diretor da sessão de arquitetura, Paolo Porteghesi ${ }^{118}$ convida Vincent Scully, Christian Norberg-Schultz e Charkes Jencks como críticos formadores da comissão organizadora - objetivando uma pluralidade de interpretações e abordagens do tema "A Presença do Passado" que, ao tratar da importância da herança histórica, claramente sugere um recorte historicista àquilo que começava a ser classificado como movimento pós-moderno ${ }^{119}$ - razão

117 "It is in its making, through the combination of its multiform expressions - the text, drawing, the building - that architecture produces and expresses its thinking". STOPANI, Teresa. "A conversation of Many". In: CHIPPERFIELD (org).Commom Ground, a critical reader. p. 87.

118 Conhecido pelo seu trabalho de historiador do período barroco.

119 Termo é atribuído a Charles Jencks, que em 1975 o utilizou para classificar alguns pontos de partida do moderno que, embora heterogêneos, direcionavam-se à sua revisão, sem que com isso intentassem a sua negação. Emprestando o termo de outros campos disciplinares, nomeadamente a literatura e a filosofia, o próprio crítico reconhece o esgarçamento de seu significado, dado a multiplicidade de movimentos e escolas que passou a agregar. In:"The presence of the past" publicado na revista Domus n ${ }^{\circ} 610$, de Outubro de 1980. p. 9 
pela qual Keneth Frampton declinaria da participação na comissão ao não concordar com o conteúdo formalista e antimoderno da exposição.

Como resultado duas são as obras mais representativas da mostra, e que até hoje são reconhecidas como seminais para a ambígua, mas eficaz categorização do pós-moderno: a controversa "Strada Novissima" 120 ,exposta na Corderie del'Arsenale e associada ao pastiche historicista, e o atemporal e enaltecido "Teatro Del Mondo", de Aldo Rossi que, por suas características e pelo contexto de sua exposição, faz com que seja reconhecido como pavilhão e, para esta pesquisa, retoma uma chave de discussão por tratar de uma inflexão significativa no sentido de uma arquitetura autônoma e autorreferente.

Segundo o arquiteto, o projeto do "Teatro Del Mondo" se caracterizava por três fatores essenciais tomados como analogias: “ter um espaço útil e preciso, mesmo se este não for necessário, colocar-se como um volume conforme os monumentos venezianos e estar sobre a água." ${ }^{121}$

O "Teatro Del Mondo" é concebido como uma obra de carpintaria, um cubo principal com suas alas destacadas do volume principal que é recoberto, no centro, por uma cúpula octogonal encerrada por uma haste metálica, que sustenta uma esfera e uma bandeira em chapa rígida. Instalado sobre uma balsa que se deslocava pelos canais de Veneza, ao longo da duração da Bienal, o teatro relacionava-se com a arquitetura local como uma imagem relativa à memória e aos monumentos locais - são famosas as fotos

120 Espécie de rua cenográfica composta por uma sucessão de fachadas que parodiavam a rua corredor abominada pelos corbusianos. Esses verdadeiros out-doors pop, desenhados por vinte escritórios selecionados de nove países - dentre eles Rem Koolhaas, Frank Ghery, Arata Isosaki, Leon Krier, Venturi e Scott Brown - serviam de anteparo e pórtico de entrada aos ambientes expositivos e prefigurava o clima de "fim da proibição", lema de Portoghesi que pretendia, a partir da superação da autonomia formal moderna, exprimir a liberdade de linguagem desejada, afim de se obter de uma arquitetura pluralista e inclusiva, uma vez que, sendo híbrido de cultura popular e erudita seria capaz de comunicar-se irrestritamente a partir de seus códigos inclusive os da tradição histórica negada pelos modernos.

121 "l'avere uno spazio usabile preciso anche se non prcisato, Il collocarsi come volume secondo la forma dei monumenti veneziani, essere sull'acqua." ROSSI. Il Progetto per Il Teatro Del Mondo" (1979). In: CELANT. Aldo Rossi, Teatri.2012, p .50. 


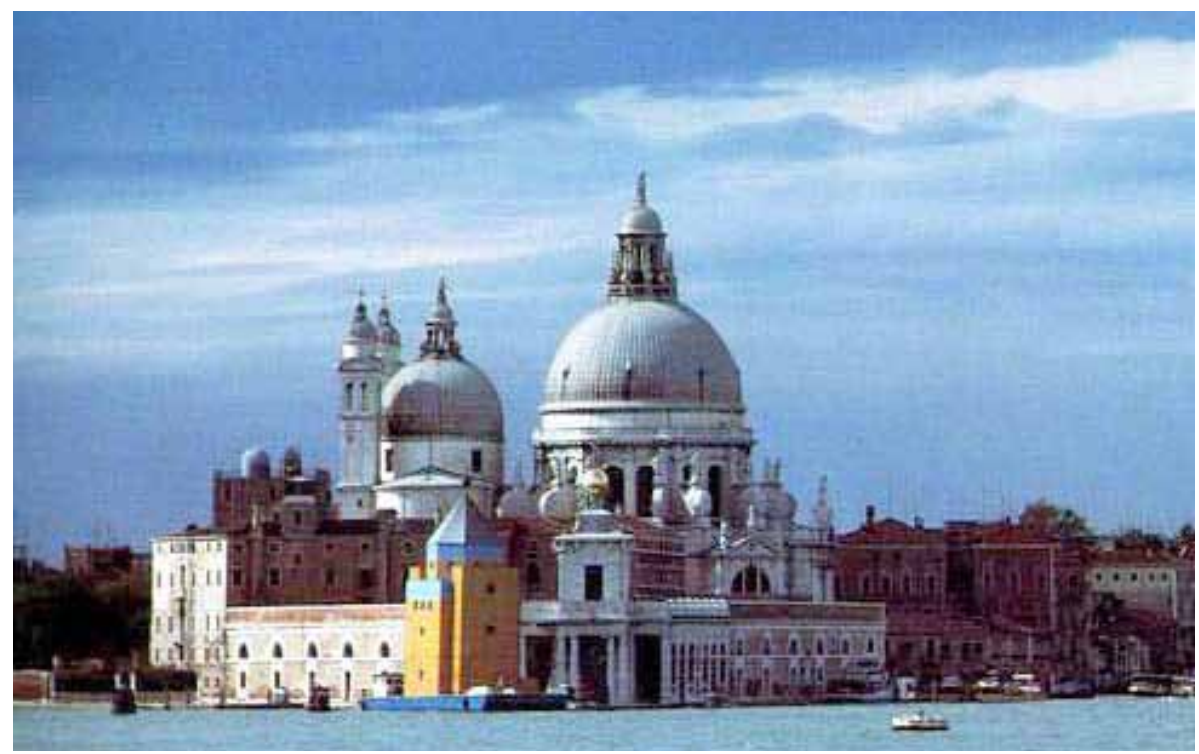

\section{figura 45}

Aldo Rossi. Teatro del Mondo - 1979-1980

(Veneza) 
em que aparece ancorado na Punta della Dogana, como se fosse mais uma tentativa de vencer a água estendendo o terreno para posicionar sua volumetria de forma a estabelecer uma relação com a cúpula da Igreja Santa Maria della Salute e sobrepor seu mastro à escultura de Mercúrio sobre o edifício da Dogana (figura 45).

A própria história da cidade é retomada em sua tradição cênica, quando teatros itinerantes eram construídos desde o século dezesseis para promover os festivais da república veneziana. Outra referência é a imagem dos faróis que o arquiteto visitara no estado do Maine - costa leste dos Estados Unidos - e representavam tanto uma engenhosa construção ancorada no solo, quanto uma imagem da "casa da luz, que observa e é observada" ${ }^{122}$. Estas referências são condensadas no pavilhão itinerante como uma figuração atemporal e sensível, que estabelece diversas analogias com a cidade e sua urbanização singular de avanço do território sobre os canais possibilitando que a cada parada da balsa o contexto determinasse o significado do tipo. Quando em Veneza, transformava-se numa barca carnavalesca, construída em madeira - opção que priorizava uma referência à tradição da construção naval local, expressa principalmente pelas gôndolas, e não motivada por uma escolha meramente funcional. Em Dubrovinik, para onde foi transportado através do mar Adriático para participar de um festival de teatro, "mostra-se apenas em um contexto diferente, onde se torna um castelo ou fortaleza fechada na cidade portuária" 123

Desta forma o programa é negado e o tipo subvertido. O interior do teatro é o espaço do palco central circundado pelos balcões que cheios ou vazios, reiteram que o espetáculo acontecerá com ou sem os autores e a plateia, uma vez que o teatro é tomado como um tipo arquitetônico, uma figuração da essência de um lugar onde se refletem os sintomas urbanos, o pavilhão de Rossi é a figuração do teatro da vida urbana, a cidade como a mais "completa

122 Idem.

123 "Il viaggio a Duborvnik lomostra appunto in um contesto diverso dove diventa como Castello o forte chiuso nel porto della città." ROSSI. "La Fortuna del Teatro del Mondo" (1982), In: CELANT. Op. cit., p. 65. 
representação da condição humana." 124

Aldo Rossi reafirma com este pavilhão que o tipo arquitetônico pode ser entendido como a própria ideia de arquitetura, e, ao descolar-se de obrigações funcionais ${ }^{125}$, estimulado pelo ambiente da Bienal de Veneza, aproxima-se de conceitos atemporais que acabaram por estabelecer um marco na historia recente da arquitetura ao condensar suas formulações teóricas de maneira precisa numa construção temporária que ficou marcada pelas ideias e discussões que suscitou.

\section{$\star \star \star$}

124 CELANT. Op. cit., p. 16.

125 "Rossi insiste na permanência da arquitetura, em sua condição atemporal, o que o leva imediatamente a descolá-la das suas obrigações funcionais. Assim, fala de uma indiferença funcional, que concede à forma arquitetônica valor próprio e elimina qualquer relação determinista entre forma e uso. Por isso, para ele a noção de tipo transcende as meras referências instrumentais e se transforma em imagem profunda. ” MONEO, Inquietação Teórica e Estratégia Projetual na obra de oito arquitetos contemporâneos. São Paulo, 2008,p. 99. 


\section{INHOTIM}

\subsection{Museu e paisagem}

O Instituto de Arte Contemporânea do Inhotim vem recebendo cada vez mais atenção nacional e internacional, consolidando-se como Instituição singular que possibilitou um importante deslocamento do eixo cultural estabelecido entre Rio de Janeiro e São Paulo no sentido do interior do país. Criado no fim dos anos 90 a partir de conversas entre o colecionador Bernardo Paz e o artista Tunga ${ }^{126}$, que o estimulou a formar uma coleção de arte produzida a partir dos anos 60 até a atualidade e abri-la para o público em sua propriedade em Brumadinho, a $60 \mathrm{~km}$ de Belo Horizonte, conta ainda com um vasto jardim com contribuições de Burle Marx. Recentemente, Inhotim vem também direcionado olhares atentos para arquitetura de seus pavilhões - ou galerias como alguns edifícios são denominados pela Instituição -, especialmente a partir da construção daquele que é visto como marco de uma transição nas relações entre arquitetura e arte neste museu, a galeria da artista Adriana Varejão, inaugurada em 2008, e projetada pelo arquiteto Rodrigo Cerviño Lopes.

A partir deste projeto, torna-se nítido que os edifícios pavilhões e galerias - fazem parte da construção da paisagem e do acervo do museu, e contribuem, através da constante expansão da coleção e das exposições temporárias, para um estudo dos agenciamentos entre artistas e arquitetos pontuando, em um contexto nacional, as potências do estudo dos pavilhões como

126 Jochen Volz. Desdobrando uma instituição: descobrindo Inhotim. In: PEDROSA, Adriano (org.). Inhotim centro de arte contemporânea. Brumadinho: 2008, p. 17. 
campo de intersecção destas práticas. Em Inhotim, segundo a arquiteta Paula Zasnicoff Cardoso - colaboradora da instituição desde 2005, e entrevistada em julho de 2011 para esta pesquisa - é possível se verificar diversas formas de colaboração entre as duas instâncias disciplinares e classificar ao menos quatro distintas abordagens ao processo de construção de pavilhões:

- A primeira onde obras pré-existentes demandam uma arquitetura de mediação que ofereça as condições necessárias para perfeita adequação e exibição da obra, a exemplo do pavilhão Doris Salcedo (2006/2008) ou do Pavilhão Cosmococas (2008-2010);

- A segunda, o pavilhão não congelado, ou seja, aquele que não está atrelado a nenhuma obra específica, devendo se adequar a exposições temporárias como o atual pavilhão Miguel Rio Branco (2008/2010).

As últimas duas linhas oferecem maior interesse para esta pesquisa e serão abordados com maior profundidade, são eles:

- Pavilhões que são parte indissociável da obra artística, desenvolvidos dentro dos estúdios dos artistas em processos de colaboração com arquitetos, ou não;

- O pavilhão Adriana Varejão, caso único onde a parceria entre artista e arquiteto opera como contaminação recíproca, ora o espaço estimula a artista, ora a obra interfere no processo de concepção espacial do arquiteto.

Distribuídos em uma parte da fazenda que possui área total de 1200 hectares de terra, alguns trabalhos já pareciam formular uma estratégia da curadoria diante das possibilidades de um museujardim, numa espécie de retorno às origens do museu moderno - o jardim de esculturas - podendo abrigar obras ambientais ou mesmo grandes projetos desenvolvidos para o contexto específico, que, por sua escala, dependem de grandes espaços e arquiteturas próprias para abriga-las ${ }^{127}$, dificilmente encontrando instituições que ofereçam condições de exibí-las permanentemente. Este fator faz de Inhotim

127 SCHWARTZMAN, Allan. Um lugar a se conhecer. In: PEDROSA (org.). Op cit. p. 26 
uma instituição única e introduz uma coleção que resgata a questão da espacialização em discussão nos anos 60 , tanto do ponto de vista físico como conceitual ${ }^{128}$."Bisected Triangle" (2002, figura 46) de Dan Graham, "By Means of a Sudden Intuitive Realization"(1996, figura 47), de Olafur Eliasson, "Folly"(2005-2009, figura 48) de Valeska Soares, e "Palm Pavilion" (2006-2008, figura 49), de Rirkrit Tiravanija, manifestam este direcionamento de construção da coleção, sendo todas obras pré-existentes que criam e ganham novos sentidos no contexto do museu-jardim. O trabalho de Graham lida com as possibilidades de reflexão da paisagem e interação do público, diluindo a noção de interior e exterior fazendo, referência à arquitetura de Mies Van der Rohe e seu paradigmático pavilhão de Barcelona - como já tratado no segundo capítulo desta dissertação - e insere na coleção o questionamento do pavilhão como elemento híbrido entre arte e arquitetura. Já Olafur Eliasson lança mão de um iglu de fiberglass como enquadramento necessário a todo o artifício criado - eletricidade, bomba e luz estroboscópica - para que infinitos desenhos de gotas de água que brotam de uma fonte no solo possam ser percebidos, isolando obra e jardim para que só então as aleatórias formas d'água tornem-se visíveis, confrontando a própria ideia de natureza à de cultura.

Assim como Graham, Rirkrit Tiravanija ${ }^{129}$ - artista de origem tailandesa nascido na argentina - utiliza-se da arquitetura como modelo ${ }^{130}$ para "Palm Pavilion", que já havia sido exposto na $27^{\circ}$ Bienal de São Paulo com curadoria de Lisette Lagnado, em 2006, cujo tema "Como viver junto" pode caracterizar boa parte de sua obra, impossível de se compreender se descontextualizada de

128 Este assundo é desdobrado por Anne Wagner no texto "Being There: art and the politics of place." In: Artforum 43, n 10, Summer 2005, p.264-269.

129 O artista ficou conhecido pelo preparo de pratos tailandeses que servia dentro dos espaços expositivos, que tinha seu estatuto comportamental modificado a partir do encontro em torno da refeição, aproximando e promovendo debates entre o público e ativando a galeria como espaço de permanência.

130 O termo é trabalhado pelo artista em diversos níveis de abstração, não somente no sentido de modelo físico ou maquete, mas também como modelo de práticas socioprofissionais, questionando o papel do arquiteto na sua adesão que positiva o estabelecido e a ordem, e por outro lado o papel dos artistas como produtores de mercadorias, podendo inverter esta lógica ao resgatar utopias arquitetônicas e a possibilidade de inserção social pela prestação de serviços. 

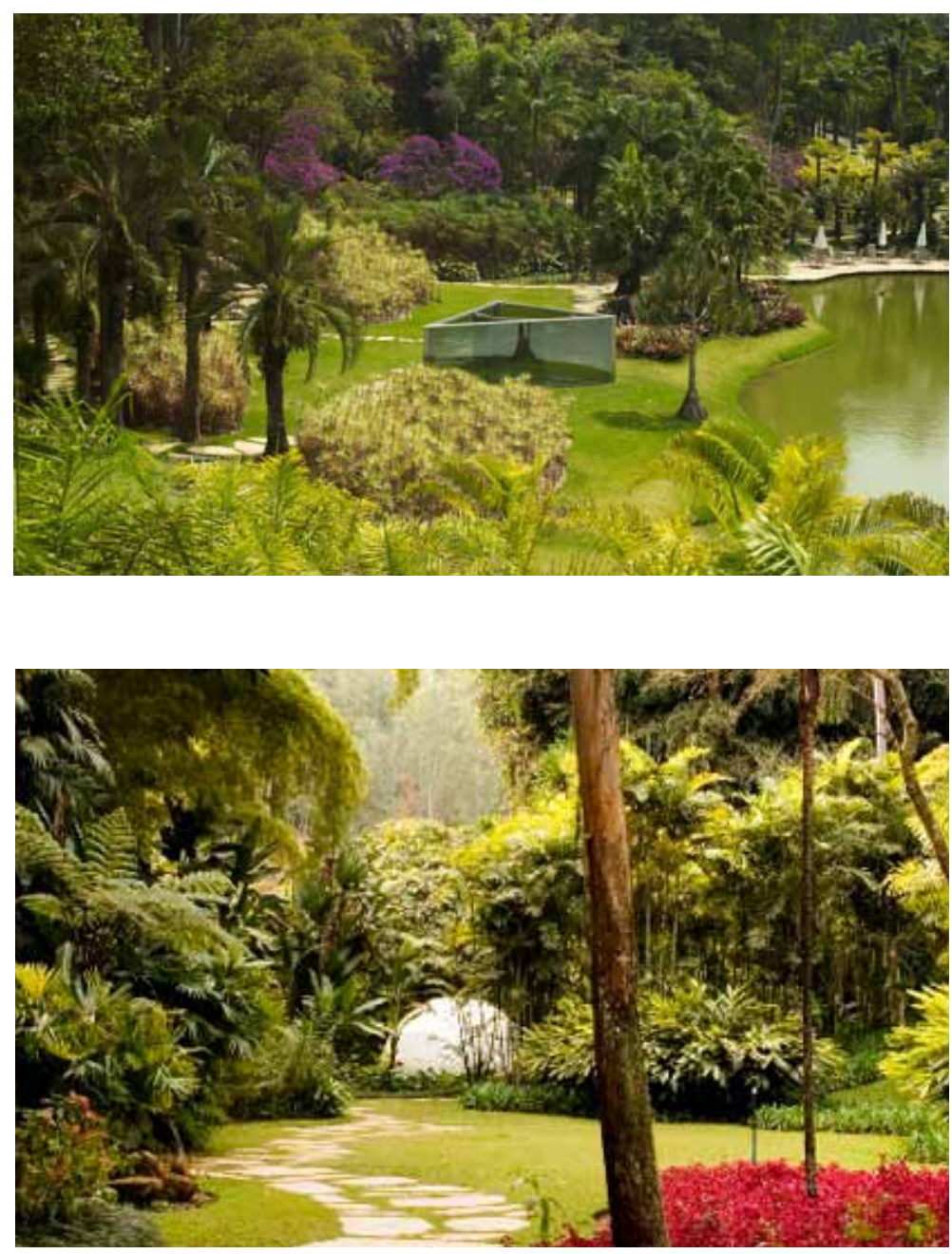

\section{figura 46}

Dan Graham. Bisected Triangle - 2002

\section{figura 47}

Olafur Eliasson. By Means of a Sudden Intuitive Realization - 1996

(Inhotim, Brumadinho, Minas Gerais) 

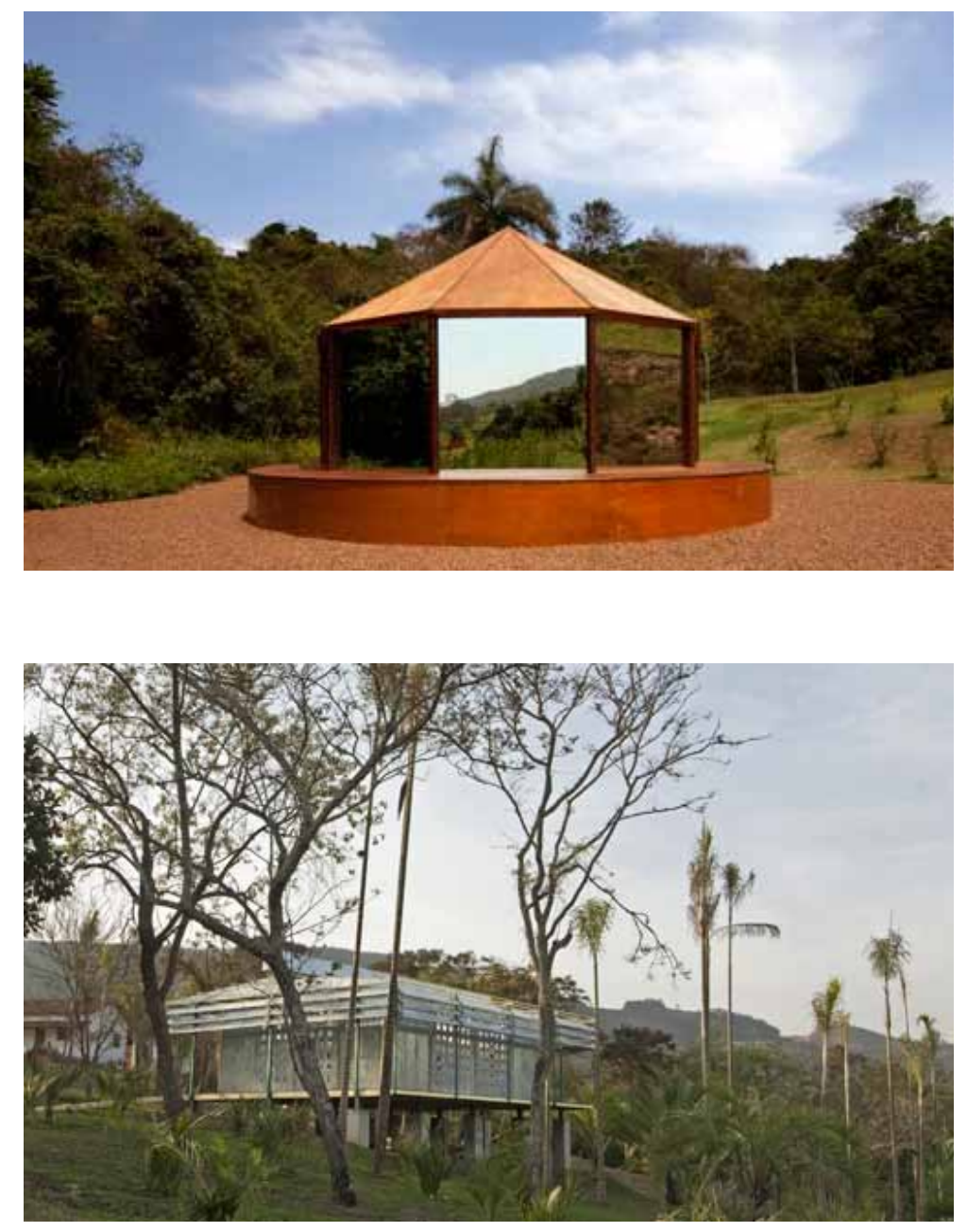

figura 48

Valeska Soares, Folly- 2005/2009

figura 49

Rirkrit Tiravanija, Palm Pavilion - 2006/2008

(Inhotim, Brumadinho, Minas Gerais) 
uma determinada produção dos anos 90 classificada por Nicolas Bourriaud como "relacional", onde artistas como Phillip Parreno, Vanessa Beecroft e Carsten Holler entre outros, propunham um uso coletivo do espaço das galerias e museus através de ações ou instalações que ativavam o convívio dentro da realidade existente da galeria, criticando os comportamentos protocolares e resgatando utopias, promovendo colaborações e problematizando a esfera das relações. Assim, seus espaços construídos revelam "uma ambiguidade entre a contemplação e o uso" 131 , ambiguidade esta que é ampliada pela precariedade construtiva da apropriação de formas arquitetônicas conhecidas, reproduzidas em escala alterada em relação aos originais. Este é o caso de outro projeto do artista "Untitled: Playtime" (1997) para o jardim do Moma, onde retoma a casa de vidro de Philip Johnson e propõe uma colisão entre o paradigma de casa moderna com as imagens do filme "Meu tio"(1958), de Jaques Tati, exibido no mesmo pátio. Esta casapavilhão ainda abrigava atividades educativas para crianças a exemplo de "Untitled: He promises" (2002) executado numa exibição solo do artista em Viena, e, posteriormente, numa exposição no Museu Guggenhein de Nova Iorque, onde Tiravanija recupera parte da casa que o arquiteto austríaco radicado nos Estados Unidos, Rudolph Schindler, construiu para si em Los Angeles, em 1922, e a utiliza como plataforma de diversas atividades - de debates a sessões de massagem tailandesa.

Este mesmo procedimento, que se vale de modelos arquitetônicos subvertidos em sua potência técnica, tornando-os capazes de alterar a percepção do olhar e do viver, está presente em "Palm Pavilion", elaborado a partir da adaptação da "Maison Tropicale" (1951), do arquiteto francês Jean Prouvé (1901-1984), originalmente pensada para a pré-fabricação industrial capaz de se adequar a montagens temporárias nas ocupações das colônias francesas na África que é revisitada com uma total precariedade da construção.

O pavilhão de Tiravanija passa a abrigar em seu interior uma

131 BOURRIAUD. Estética Relacional. São Paulo, 2009, p.49. 
série de objetos - ilustrações, capas de livros, cartões postais, células de dinheiro e ainda um vídeo de testes nucleares realizados no Pacífico Sul - onde palmeiras estão em primeiro plano. Elevada a ícone cultural, a palmeira simboliza a situação paradisíaca tropical e desperta no público um entendimento das alianças positivistas às quais esta arquitetura se submeteu.

Neste sentido, Tiravanija diz:

"Interessa-me encontrar estruturas e dispositivos capazes de circunscrever as condições que nos encontramos. Ao empregar a linguagem arquitetônica, ou modelos de linguagem, é possível elaborar um contexto: marcos tornam-se visíveis, e as ações ganham um lugar. Sempre devemos questionar o marco e a forma como existimos." ${ }^{132}$

Como complemento, em sua montagem no Inhotim, a obra ganhou um jardim com diversas espécies de palmeiras e um quiosque onde se pode comer e beber, mas como não poderia ser diferente, no cardápio apenas água de côco e empadas de palmito. Assim como em outros pontos do impecável jardim botânico que, por suas atrações, por vezes, nos remete à lembrança de um parque de diversões, pode-se perceber a esta altura uma acidez destoante, um programa de intenções que ao ser reativado pelo novo sítio estimula o público a uma revisão crítica das instituições e, porque não, da própria instituição que o abriga.

Ao usar o pavilhão como um readymade arquitetônico, reativado por sua montagem ao ar livre no Inhotim, Tiravanija retoma o potencial crítico da arquitetura como sistema de linguagem, e trabalha a noção de programa como conteúdo estratégico na construção de sociabilidades percorrendo um caminho diametralmente oposto aos procedimentos "artísticos" incorporados por arquitetos em eventos recentes, incentivadores da

132 "Me interesa encontrar estructuras y dispositivos con los que enmarcar las condiciones en las que nos situamos. Al emplear el lenguaje arquitectónico o modelos de lenguaje puede elaborarse un contexto: los marcos se hacen visibles y las acciones pueden tener lugar. Siempre debemos cuestionar el punto de referencia y cómo existimos." Entrevista cedida a Carmem Cerbreros para o periódico mexicano "Tomo", disponível em: <http://tomo.com. $\mathrm{mx} / 2008 / 08 / 29 /$ rirkrit-tiravanija/> consultado em 10/10/2011. 
construção de pavilhões.

Valeska Soares também recontextualiza sua obra "Tonight" (2002) resgatando o conceito de follie como um arquétipo de arquitetura de uso público para o entretenimento e o lazer. Exibida originalmente na boate do Cassino da Pampulha, um casal dança separadamente e desacompanhado ao som de "The Look of Love"133, trazendo o espectador para a cena de clima nostálgico e inebriante através das reflexões e sobreposições da imagem filmada naquele mesmo local. Em 2005, a artista já havia exibido o filme como parte da instalação "Folly" (2005-2009), um gazebo de jardim - que remete ao clima de frivolidade decorativa destas estruturas típicas dos parques do século XVIII na Europa. Uma construção leve em madeira de forma octogonal reflete em seu interior a imagem nas suas superfícies espelhadas. Em Inhotim, o pavilhão é pensado desde seu exterior como preparação multisensorial para a obra através da interação da artista com a equipe de paisagismo, elaborando um percurso que sensibiliza o espectador para o tempo da obra, reduzindo a velocidade do caminhar, dificultada pelo trajeto de pedriscos, e estimulando o olfato pela escolha dos aromas do jardim.

Jardins e parques são o local de florescimento de pavilhões e follies no século XVIII na Europa, entendidos como elementos arquitetônicos de grande carga representacional e, ao mesmo tempo, elementos autônomos integrados ao conceito de natureza construída de então, capazes de representar um refúgio das convenções sociais ${ }^{134}$ e que em Inhotim, são retomados como potente tríade jardim, escultura e pavilhão. Isto permite um oportuno estudo de caso contemporâneo no âmbito nacional, onde pelo entendimento de que a arquitetura está em exibição mimetizada às esculturas no jardim botânico, reafirma-se a premissa de que o pavilhão, como tipologia arquitetônica, aproxima-se historicamente do conceito

133 Música de Burt Bacharach interpretada por Dusty Sprigfield para a trilha sonora do filme Cassino Royale, de 1967, uma paródia dos filmes de James Bond e seu excessivo glamour.

134 Barry Bergdoll, professor de arquitetura moderna na Universidade de Columbia destrincha esse histórico dos pavilhões como preâmbulo das Feiras Internacionais onde os pavilhões ganham destaque por sua carga de representação nacional em artigo do catálogo: "The Pavilion, Pleasure and Polemics in Architecture". Op. cit., p.14. 
de campo ampliado, especialmente no que diz respeito à oposição dos termos paisagem e não-paisagem - o local demarcado - e arquitetura e não arquitetura - a estrutura axiomática ${ }^{135}$.

O processo de seleção e coleção de obras em andamento em Inhotim reforça a construção deste debate ao desvelar esta linha de convergência disciplinar, visto que não está em foco uma contribuição do espaço arquitetônico para a escultura e instalação, ou da escultura e instalação para a arquitetura, mas sim a tendência de uma unidade espacial da obra onde não há distinção entre "o espaço da exposição e a exposição da obra"136. Com isso, os pavilhões projetados como espaço indissociável da obra artística serão o alvo de análise da pesquisa, e não aqueles que podemos entender como galerias, no sentido de terem sido projetadas como invólucro capaz de proporcionar as necessidades técnicas de exibição de uma obra pré-existente.

135 Ver a relação entre os textos de Rosalind Krauss "Sculpture in the Expanded Field" e o de Anthony Vidler "Architecture's Expanded Field" desenvolvida no primeiro capítulo desta dissertação.

136 Frase de Beatriz Colomina em Conferência proferida no Now Museum disponível em disponível no site fórum permanente: <http://www.forumpermanente.org/.event_pres/ simp_sem/conferencia-internacional-the-now-museum/ >consultado em 20/06/2012. 


\subsection{Uma galeria para uma obra específica.}

A galeria da artista Doris Salcedo é um dos exemplos de galeria construído para abrigar uma obra específica. "Neither" (2004) havia sido exposta originalmente na galeria White Cube, em Londres, e elaborada por Doris Slacedo após uma visita ao campo de concentração de Auschwitz, tensionando o papel da arquitetura que pode oscilar entre o abrigo e o aprisionamento. Constituída de placas de LDF, gesso e aço - cada uma com a dimensão de 494 x 740 x $1500 \mathrm{~cm}$ - foi remontada em um pavilhão projetado para se adequar a sua exibição, recriando o espaço de origem da obra. A prioridade do projeto - conduzido pela arquiteta Paula Zasnicoff em parceria com o arquiteto colombiano Carlos Granada, constante colaborador da artista - foi possibilitar a perfeita conservação dos painéis, revelada por procedimentos como a elevação do piso do contato direto com o solo, a antecâmara de acesso ao salão principal, que soluciona a refrigeração sem a necessidade de portas giratórias, a criação de um corredor técnico essencial à montagem e conservação da obra, e o uso de um forro acústico que garante o isolamento necessário do salão principal.

"Neither" é uma obra voltada para seu espaço interior e o projeto arquitetônico valoriza esta relação com uma volumetria austera, que funciona como precisa moldura espacial de sua sala central, proporcionando sua viabilidade física e técnica. Entretanto a existência da obra precede seu invólucro e sua "abordagem de tensão sobre a arquitetura" ${ }^{137}$, que remete aos campos de concentração e prisões com suas grades que nos envolvem e se descolam da parede até quase encerrarem a entrada, acontecem no seu interior de forma independente ao pavilhão.

137 Segundo texto da curadoria assinado por Schwartzman, Jochen Volz e Moura. PEDROSA (org.). Op. cit., p. 42. 
A troca de desenhos entre a arquiteta brasileira e o arquiteto colombiano demonstra que, uma vez decidido o local de implantação da obra - entre o território transformado pelo parque e a mata nativa da fazenda demarcando uma fronteira que enfatiza as circunstâncias de "Neither" e inaugura um novo eixo de desenvolvimento do museu -, o processo de ajuste da volumetria externa pouco se alterou. Apenas a antecâmara de acesso foi rebaixada e marcada como elemento de transição e preparo para o contato com a obra no salão principal. A luz filtrada que penetra por uma claraboia contribui para que o espectador experimente esta transição entre interior e o exterior. (figuras 50 e 51)

A maior interferência na parte externa do volume, e que remete ao que se experimentará em seu interior, se deu por ocasião da visita da artista pouco antes da conclusão da obra, quando a parede rebocada que aguardava acabamento e pintura foi tratada e assim mantida, ressaltando sua textura e aspereza. 

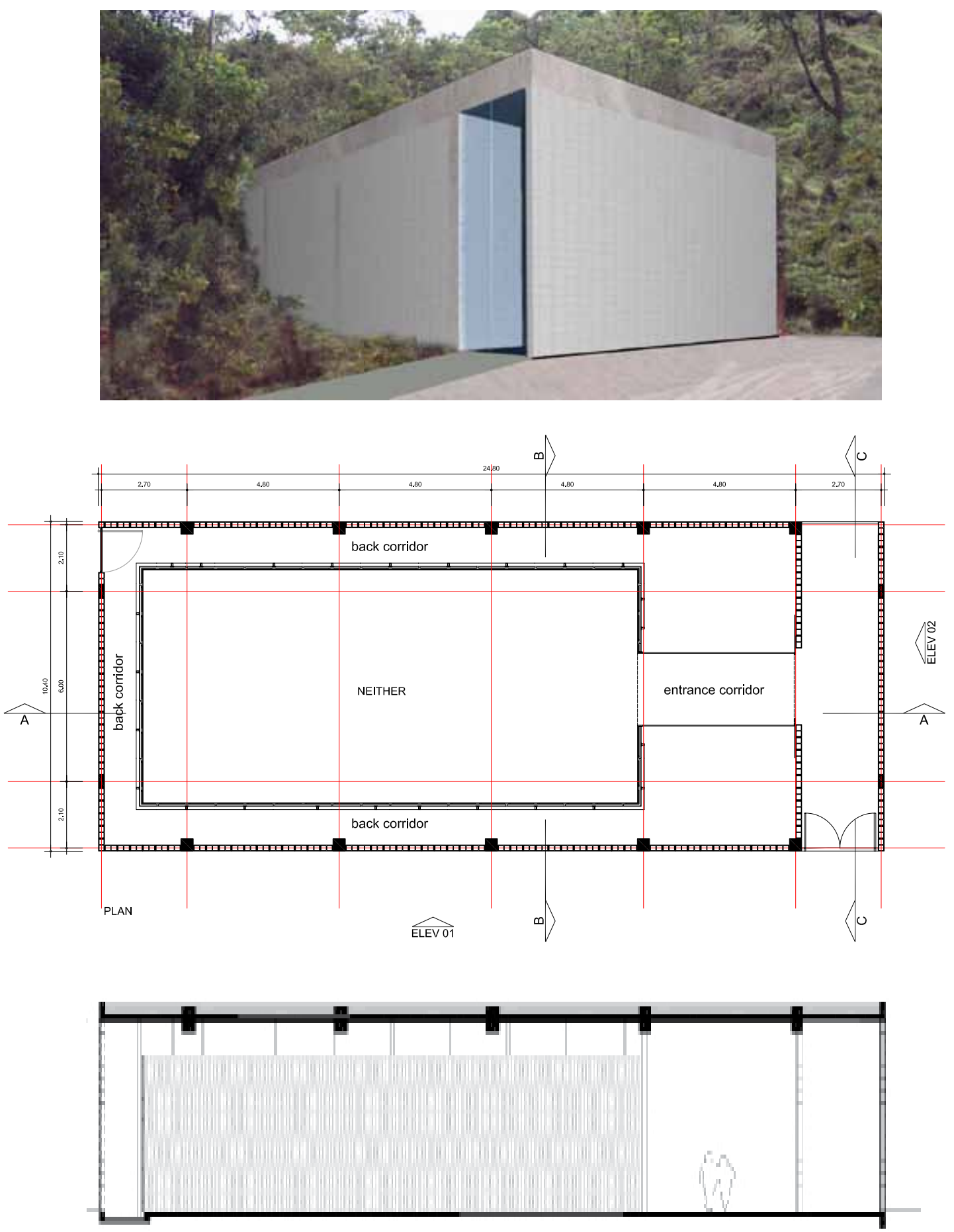

\section{figura 50}

Paula Zasnicoff. Pavilhão "Neither", modelo, planta e corte transverso 2006 (Inhotim, Brumadinho, Minas Gerais) 

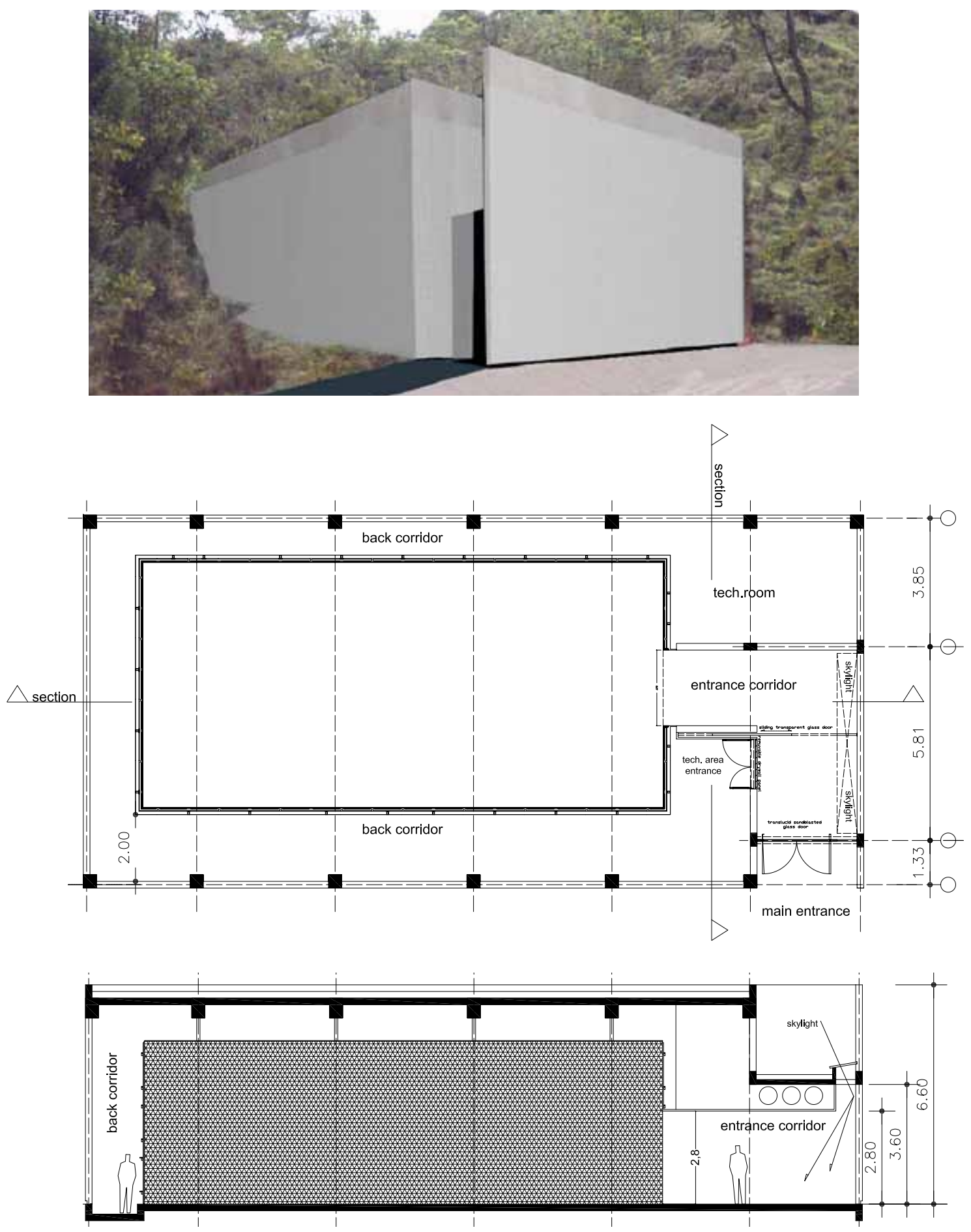

figura 51

Carlos Granado, Pavilhão “Neither”, modelo, planta e corte transverso 2006

(Inhotim, Brumadinho, Minas Gerais) 


\subsection{Os pavilhões de Doug Aitken e Matthew Barney.}

Doug Aitken e Matthew Barney são dois artistas norteamericanos cuja produção tem forte fundamentação no uso do vídeo, onde a arquitetura aparece ora como protagonista de ações e intervenções escultóricas, ora como suporte para grandes projeções transformadoras do espaço, ou mesmo como dispositivo de formalização da obra. No caso de Inhotim suas instalações extrapolam o limite de qualquer galeria e são os próprios pavilhões.

Ambos os artistas projetaram seus pavilhões com a colaboração de arquitetos integrantes de suas equipes, sendo que Hisako Ichiki, arquiteta da equipe de Aitken, já havia passado pelo escritório SANAA. O que se inverte em relação ao desenvolvimento de "Neither", por exemplo, é que os projetos já são encaminhados pelos artistas como integrantes de um todo que constituí a obra e não são entendidos como mediação, ou seja, espaço expositivo que abriga um objeto passivo.

O texto da curadoria para "Sonic Pavilion" (2009) estabelece uma relação de descendência desta obra para com os earthworks das décadas de 60 e 70 e apresenta uma aparente incongruência: uma obra sitespecific desenvolvida a partir de uma ideia pré-existente. Em princípio, e especialmente pelas imagens do estudo (figura 52), nota-se que o local genérico é plano e remete a um deserto, palco de uma parte seminal das obras de Robert Smithson e Michael Heizer.

A escolha do lugar foi decisiva para a adaptação da proposta inicial. Implantada no ponto mais alto do parque, o percurso de acesso ao pavilhão se desenrola de forma espiralada num movimento contínuo desde o exterior e conduz o público ao interior do salão circular em um movimento que cria uma ilusão ao conferir a sensação de que o que esta em rotação é o edifício cilíndrico, como se fosse 

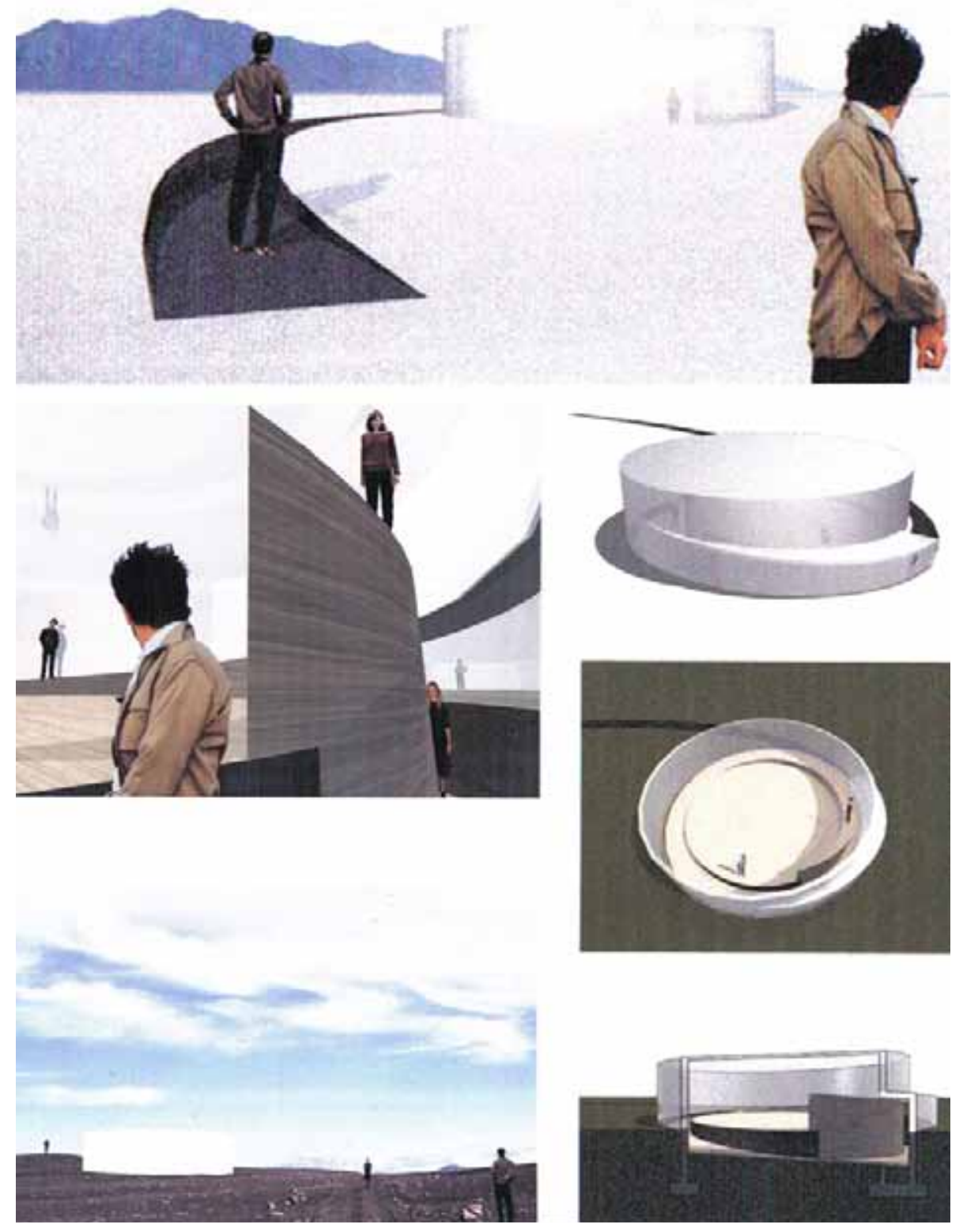

figura 52

Doug Aitken, estudo preliminar para Sonic Pavilion - 2006 
um rolo de filme. O que gira não é o edifício, mas os pontos de vista do observador em sua trajetória que se encerra frente à escotilha que recobre a perfuração de $200 \mathrm{~m}$ de profundidade. A ênfase em atribuir ao espectador o papel de editor das imagens através de seu deslocamento no espaço é uma estratégia constante no trabalho Aitken, interessado nas possibilidades de representação de um mundo em constante transformação, onde a forma é fugaz. Tanto em seus vídeos, onde os personagens de filmes estão sempre reféns de uma situação, ou de algum acontecimento por vir, sobre o qual não têm o menor controle, quanto em suas instalações, Aitken lida com a arquitetura que manipula como um elemento de suspensão onde espectador se vê envolvido em fragmentações e desmontagens do espaço e do tempo.

A arquitetura, inicialmente personagem de seus vídeos, passa a ser também suporte, como nas duas instalações em que o artista usa todo o espaço do museu e subverte seus percursos pré-estabelecidos, o que potencializa suas particularidades espaciais. Em "New Ocean" (2001- figura 53), na Serpentine Gallery, em Londres, a forma cilíndrica já aparecia como resultado do desejado ciclorama e em "Sleepwalker" (2007) no Moma de Nova Iorque, as projeções ganharam escala urbana e são impossíveis de serem vistas em conjunto e ao mesmo tempo, impondo um deslocamento na cidade. Neste sentido Aitken diz procurar: "criar um espaço narrativo, ou uma arquitetura narrativa, onde todo elemento pudesse tornar-se um disparador e, para que certas ideias existam, ...esperançosamente cendendo ao espectador mais para explorar e navegar. "138

A pesquisa com a arquitetura não se desenrola somente na forma como a projeção de seus vídeos ocuparão o espaço expositivo, mas também implicam a construção deste espaço independente do vídeo, como em “No History” (2005- figura 54), onde centenas de espelhos hexagonais, que se movem, são distribuídos ao longo de um corredor com uma grande superfície reflexiva em seu fim, convidando

\footnotetext{
138 "..creating a narrative space, or a narrative architecture where all the elements could become like a trigger and for certain ideas to exist...hopefully giving the viewer more to explore and navigate." In: "Doug Aitken, Signs of the times" entrevista concedida à Térésa Faucon e Damien Sausset - Art Press, n³19, Janeiro de 2006. p.23.
} 

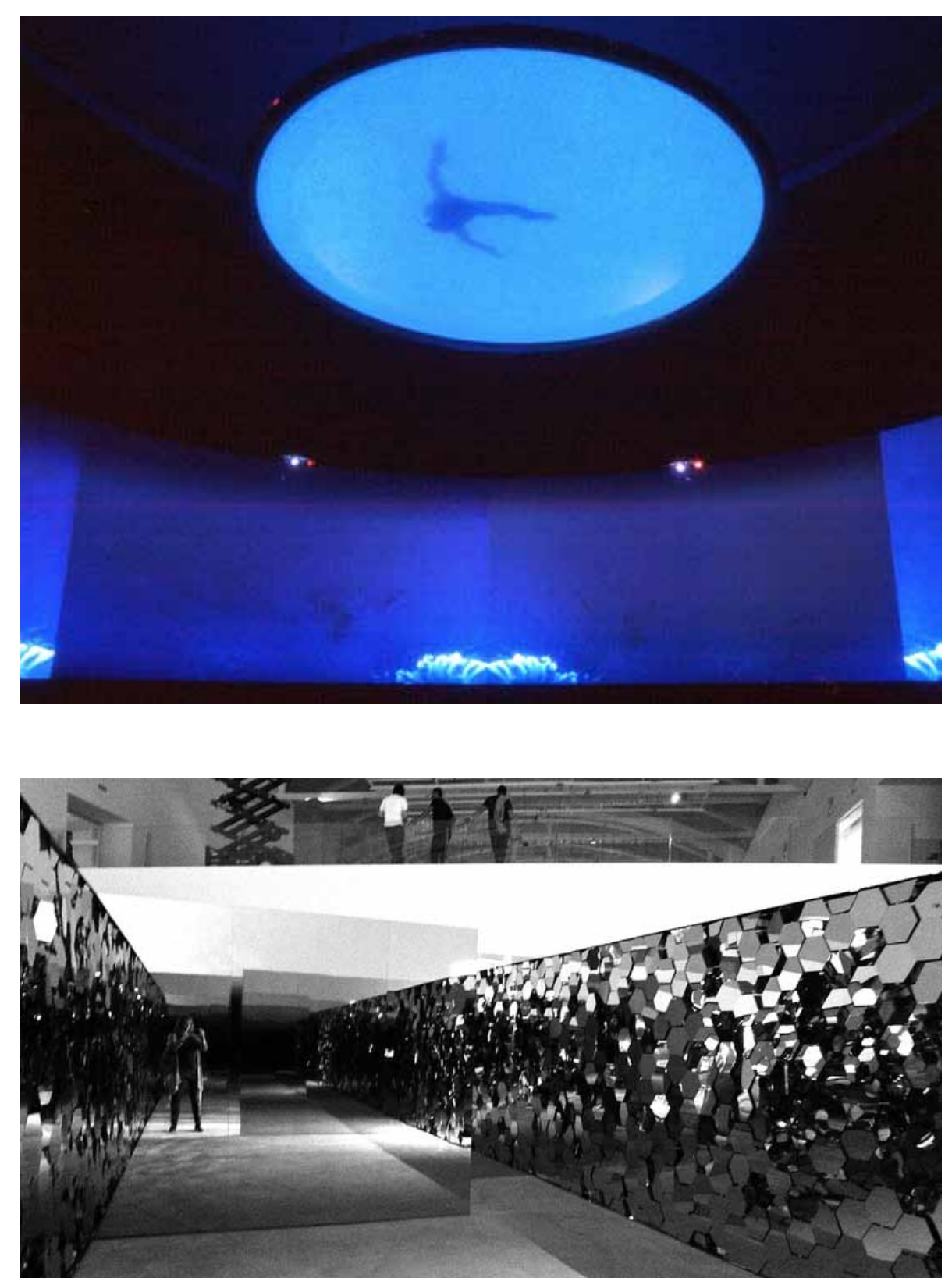

figura 53

Doug Aitken, “New Ocean"- 2001

(Serpentine Gallery, Londres)

figura 54

Doug Aitken, “No History"- 2005

(Thyssen-Bornemisza Art Contemporary, Viena) 


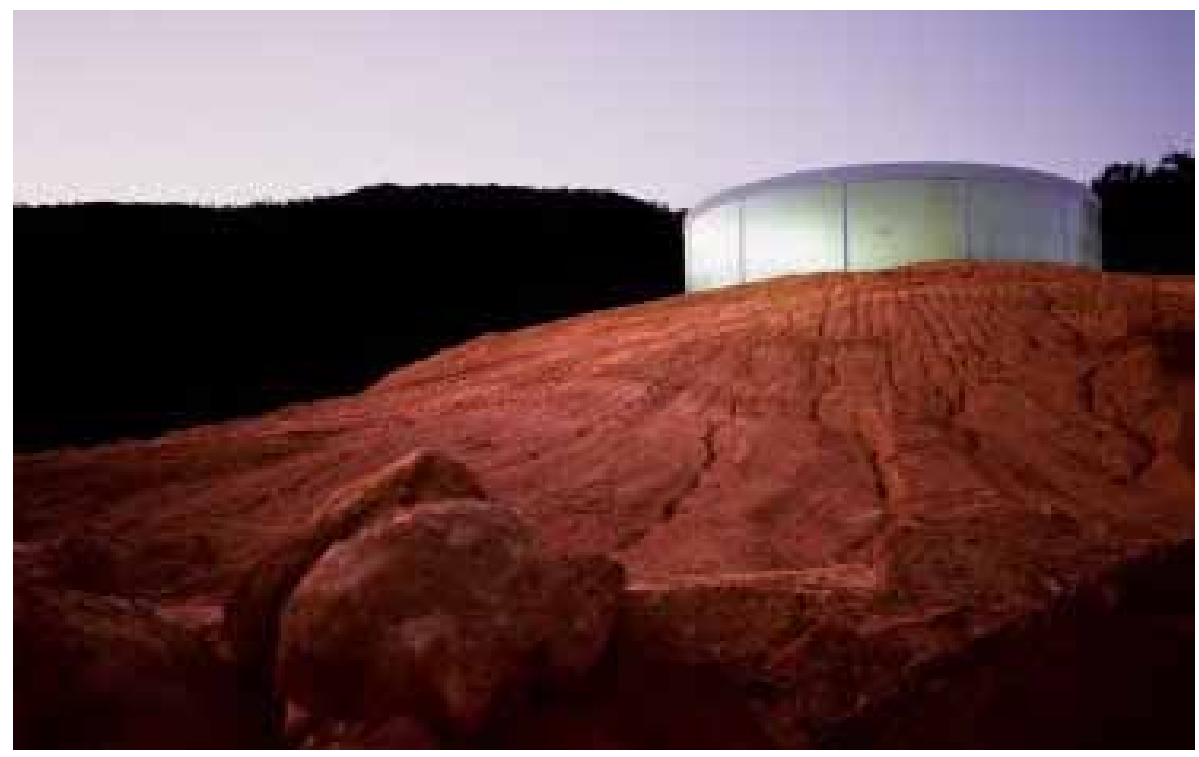

\section{figura 55}

Doug Aitken. "Sonic Pavilion" - 2002

(Inhotim, Brumadinho, Minas Gerais) 
o espectador a se perder ao acompanhar a reflexão que reconstrói sua imagem desintegrada.

Outro elemento essencial no trabalho de Aitken, e que representa o cerne da instalação em Inhotim, é som. Gravações feitas em campo e em colaboração com músicos fazem parte de seus vídeos, mas em "Som da Terra" a ideia de adaptar a prática comum a geólogos que usam microfones e alta tecnologia para captar o rompimento de placas glaciais na Antártica - é adaptada para revelar uma música cujos loopings e repetições - assim como na tradição da música minimalista, representada por compositores como Terry Riley - conformam um ritmo naturalmente aleatório produzindo uma composição que jamais será a mesma. Por outro lado, esta intenção levanta, para os céticos de plantão, a dúvida sobre se o que estamos a escutar é mesmo o som emitido pelos movimentos das entranhas da terra, o que só reafirmaria o discurso do artista de que "tudo é ficção" ${ }^{139}$, edição e ilusão.

O pavilhão (figuras 54, 55 e 56) serve, portanto, como espaço para abrigar a escotilha que recobre o furo de $200 \mathrm{~m}$, a fim de registrar os sons da terra, e foi pensado pelo artista como uma arquitetura reduzida a seu mínimo, conforme descreve em seu memorial descritivo, desde quando o local para sua execução ainda era indefinido. O cilindro, elemento essencial de fruição da obra, possui escala suficientemente grande para abrigar um determinado número de pessoas, mas é também, pequeno o suficiente para gerar uma atmosfera de calma e abrigo sobre o deck de madeira que se transforma em banco à medida que a rampa de acesso se desenrola pelo interior.

A película, que acentua a refração dos vidros curvos, embaralha a visão impedindo que o pavilhão torne-se um mirante, aproximando-o de um ciclorama. Ao decupar a imagem, paisagem e som, remete-nos ao processo de edição cinematográfica, e ao dispor a geometria do espaço de forma circular, nos direciona ora para os dois furos centrais - um no piso e outro na cobertura ${ }^{140}$ - ora para a tentativa de absorção

139 Ibidem. p.25

140 O furo na cobertura surge como consequência do desenvolvimento do projeto executivo e contribui complementando o sentido de desconhecido e infinitude tanto para o centro da terra quanto no sentido contrário. 


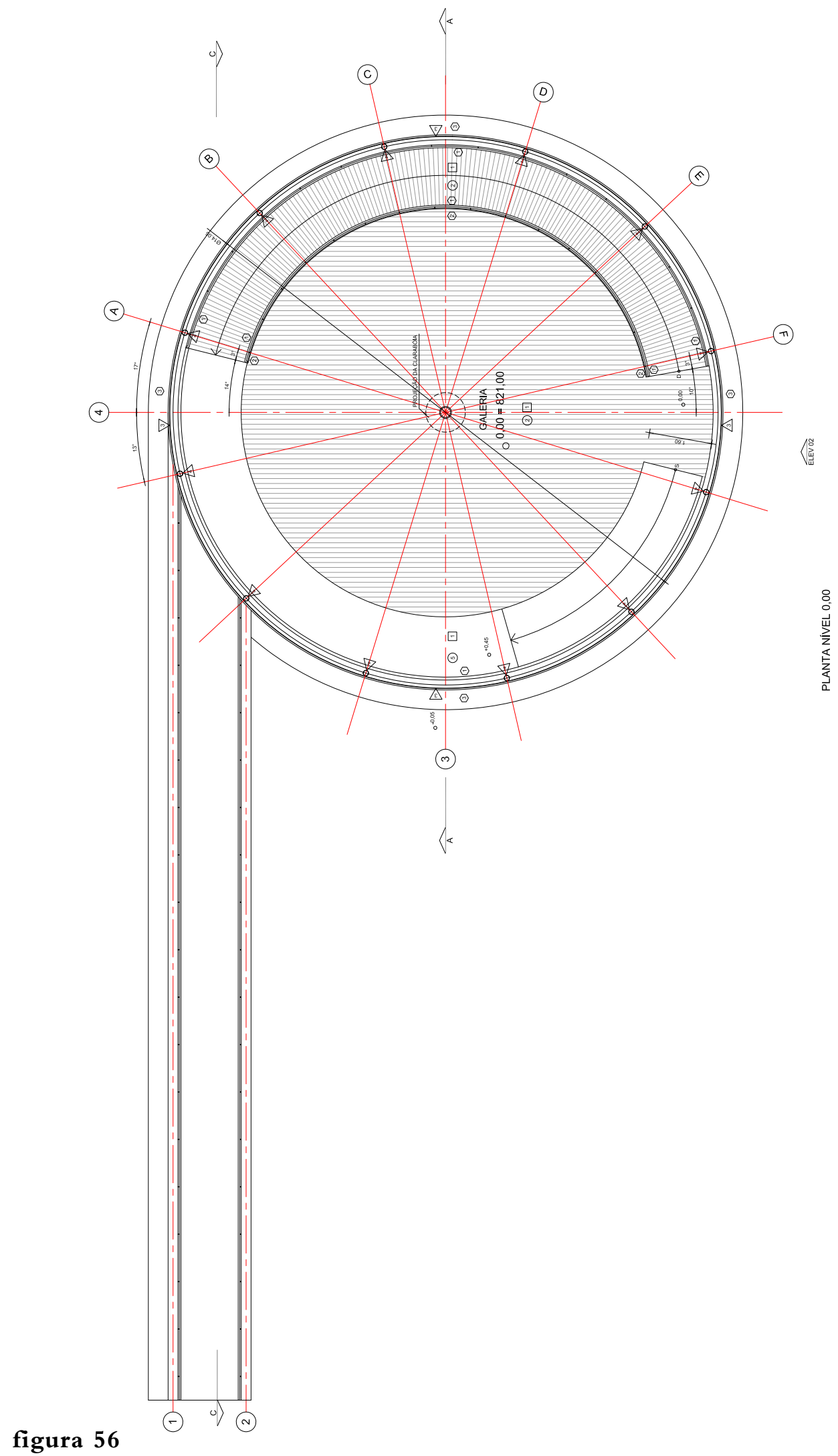

Paula Zasnicoff. Planta executiva. Sonic Pavilion - 2008 

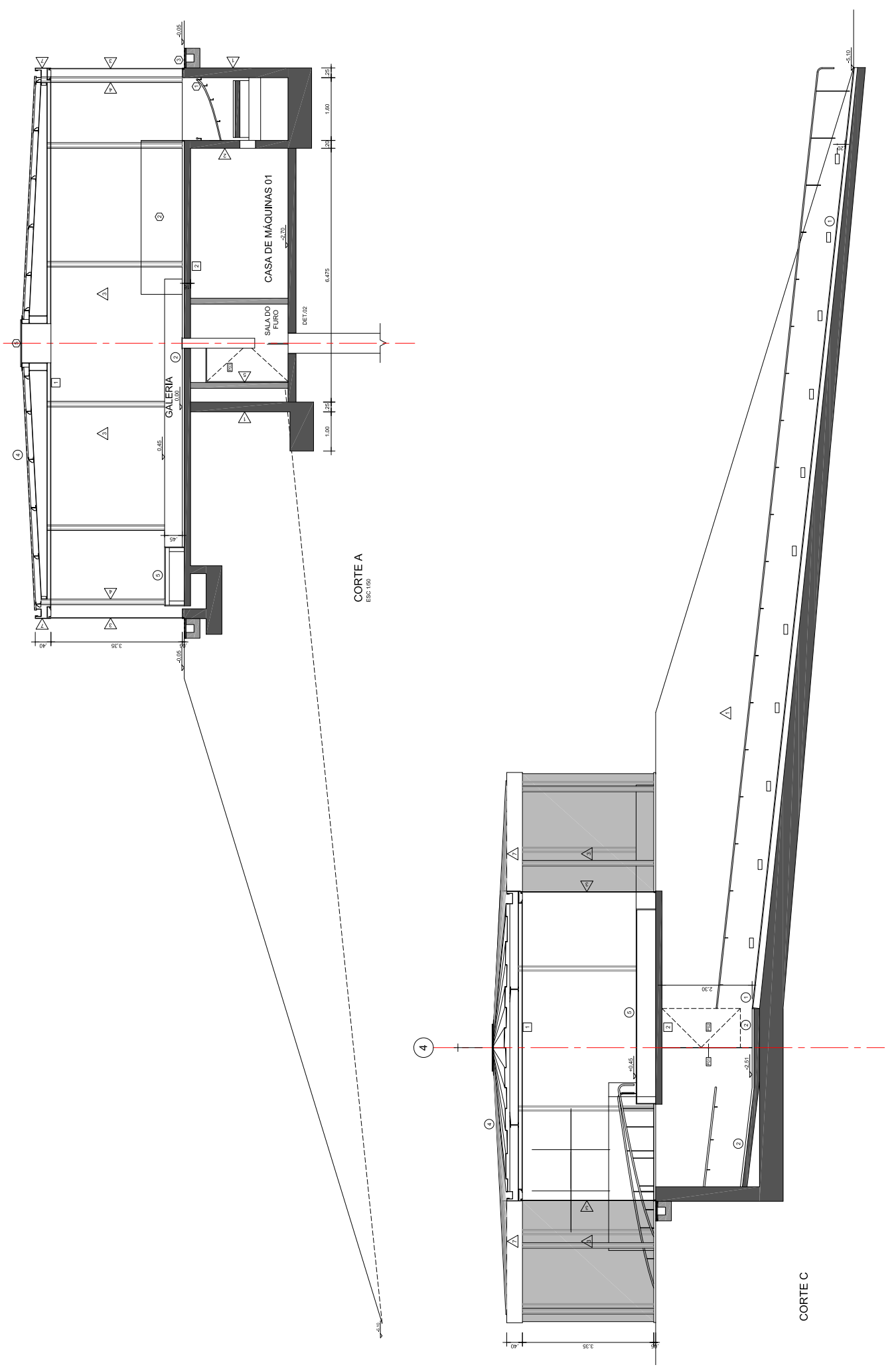

figura 57

Paula Zasnicoff. Cortes executivos. Sonic Pavilion - 2008 
da paisagem dificultada pela película que embaça a vista periférica, colocando o espectador em constante movimento, que sempre busca novo foco, numa reafirmação de sua presença naquele espaço-tempo. Assim, o público é transformando em editor de sua experiência com a obra e o pavilhão, numa máquina de visibilidade alterada.

Aitken lança mão de recursos arquitetônicos que propiciam a plataforma necessária e inseparável para a fruição do som captado à $200 \mathrm{~m}$ de profundidade e é amplificado por oito caixas de som distribuídas radialmente, assim como os pilares que sustentam este cilindro de vidro. O desenvolvimento da obra, conforme parte do projeto executivo aqui apresentado, demonstra que pouco se alterou em relação ao estudo preliminar. As adaptações necessárias são relativas à implantação e acomodação do edifício ao terreno, com algum ajuste de rampas e níveis. Não tendo mais que descer para permanecer ao rés do chão, foi possível proporcionar a noção de continuidade ascendente conforme os cortes (figura 57). Foi apenas necessário um ajuste do terreno de forma que fosse possível a instalação das casas de máquinas e a acomodação da rampa, com o consequente aterro do embasamento. Isto revela que o artista sempre imaginou este pavilhão como elemento a ser replicado em outros pontos da terra, gerando sempre uma sincronicidade entre quem estiver, nun dado momento, partilhando a mesma experiência ${ }^{141}$.

Mathew Barney, artista norte-americano, produz trabalhos de difícil classificação ao abraçar diversas mídias e práticas, expandindo os limites e suportes artísticos comuns, ao mesmo tempo em que tem pleno domínio e consciência da inserção de suas obras no contexto da arte, assim como um entendimento da importância do papel das instituições artísticas nas suas transgressões. Barney declara que o "museu é o lugar de reunião deste todo formal claro" ${ }^{142}$, e no caso de um museu com características únicas como Inhotim, este todo abrange também, como não poderia deixar de ser, a arquitetura como geradora

141 Entrevista a Guy Trebay concedida em 25 de setembro de 2009 disponível em: $<$ http://www.artinfo.com/news/story/32796/doug-aitken> consultado em 15 de Agosto de 2011.

142 Em entrevista concedida a Hans Ulrich Obrist em julho de 2002, compilada no livro “Arte agora!", 2006.p.15. 
da unidade da obra.

"De Lama Lâmina" começa como uma performance realizada ao longo de um desfile de bloco carnavalesco em Salvador, em 2004. A evolução do bloco, nos leva a crer que o desfile, por si só, já configuraria uma performance, mas Barney, em parceria com o músico Arto Lindsay ${ }^{143}$, insere um enredo que entrelaça ao carnaval duas ações que acontecem ao longo do desfile. Uma que se revela para o público, e outra só percebida pelo espectador do filme de 60 minutos de duração ${ }^{144}$, concluído em 2005, e exibido em diversos festivais de cinema e vídeo ${ }^{145}$. Neste filme, um homem animalizado representa Ogum - orixá dos metais que transforma em ferramentas para a agricultura, mas também para a caça e a guerra - e sob o um trator florestal de 40 toneladas (imagem 58), interage com as engrenagens enquanto este carrega uma árvore, recém extraída do solo, em cujos galhos uma mulher, Ossanha - a orixá das florestas, relacionada aos processos de cura por deter o conhecimento medicinal das ervas constrói uma espécie de estrutura geodésica com bastões de cera que revestem seus galhos. Com o desenrolar do filme e o andor do "trator carro alegórico abre alas" ao longo da avenida, a engrenagem é envolta em barro pelo personagem masculino - o que prenuncia sua iminente parada, dado o acúmulo do barro - e passa a funcionar como seu instrumento de excitação que o leva a atingir o clímax no momento em que a geodésica alcança seu equilíbrio como estrutura, e com isso o bloco carnavalesco se encaminha para apoteose do desfile.

Barney retoma os temas que permeiam sua obra,

143 "De lama a lamina" integra o álbum Salt, lançado por Lindsay em 2004 e sua letra trata das transmutações entre o estado orgânico e matéria presentes no trabalho:

"De chuva, aço. De tronco, trovão. De folha, ferro. De ferro, raiz. De ouro, olhar. De prata, vermelha.

De peixe, perna. De peito, bico. De cobre, dedos. De prego, farinha. De cabeça, ar. De ouro, olhar. De prata, vermelha."

144 O filme "De Lâma Lâmina" tem direção de Matthew Barney; direção de fotografia de Peter Strietmann; música composta e executada por Arto Lindsay; desenho de produção de Matthew D. Ryle; produção de Barbara Gladstone e M. Barney; lançado pela Gladstone Gallery.

145 Barney ressalta a importância de ter realizado um filme dependente de um contexto real, resultando em um filme curto se comparado ao seu projeto anterior, a série "Cremaster", que tem três horas de duração, e levou três anos para ser concluída. Em Inhotim, o filme é apresentado em três sessões ao longo do dia em uma galeria separada do pavilhão e organizada como sala de projeção cinematográfica. 

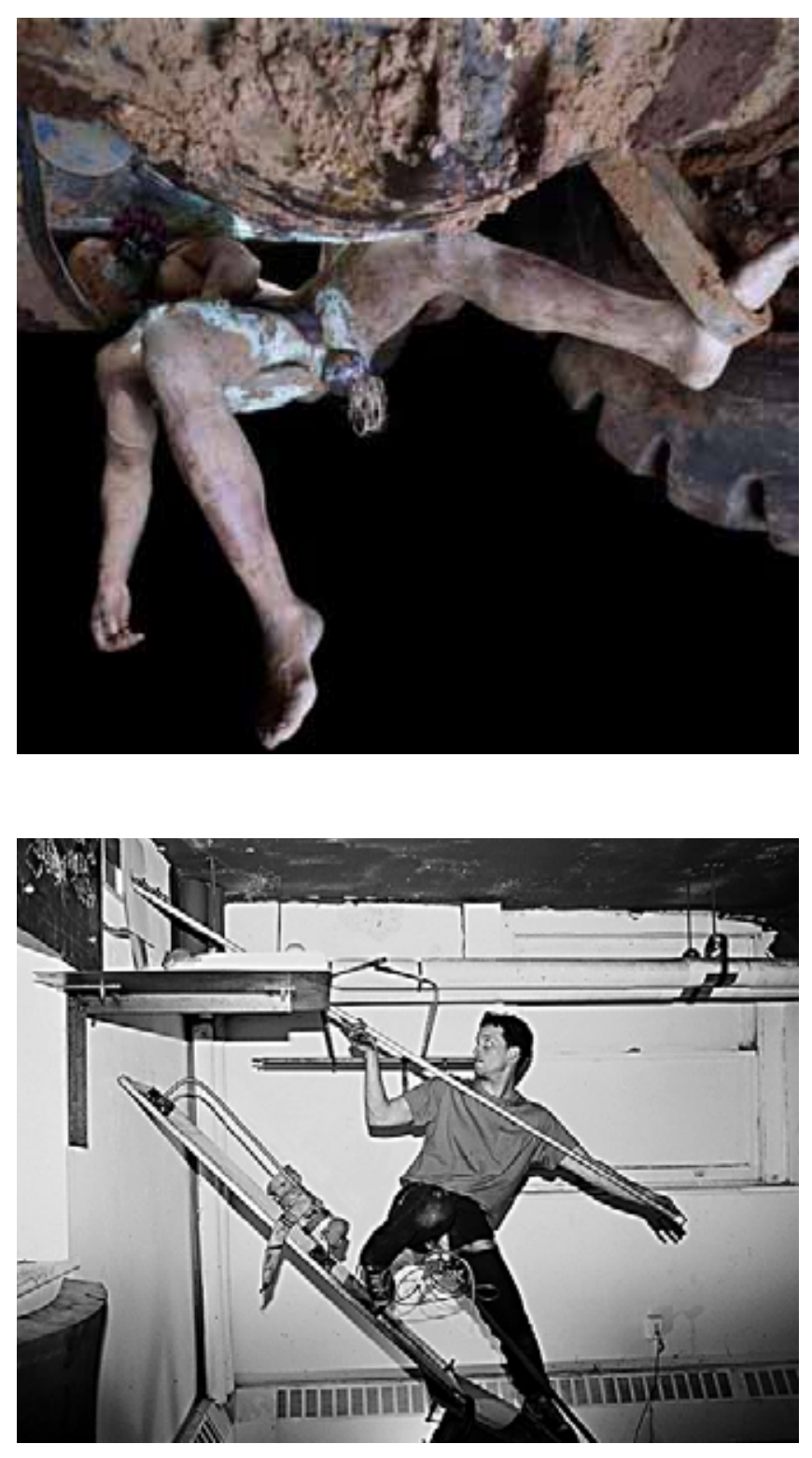

figuras $\mathbf{5 8}$

Matthew Barney. De Lama Lâmina -2004

figuras 59

Matthew Barney. Drawing Restraint -1987 
especialmente a mais ambiciosa e mais famosa, o ciclo de cinco filmes "Cremaster"(1994-2002). A aproximação com mitologias, iniciada na peça desenvolvida para a $9^{\circ}$ Documenta de Kassel, “OTTOShaft"(1992), é revisitada agora com os orixás do candomblé, o erotismo biomecânico é traduzido na relação do homem-divindade tomado por sementes e plantas em sua interação com a engrenagem da máquina, o corpo levado ao limite do esforço físico durante a performance - presente na serie de trabalhos "Drawing Restraint", iniciada em 1987 (figura 59) - e a tentativa de alinhamento entre filme e escultura, através de uma narrativa musical, revela seu interesse pela ópera como obra de arte total. Em “De Lama Lâmina”, Barney transpõe sua narrativa musical para o contexto do carnaval baiano envolvendo os passistas, a bateria e o carro alegórico abre-alas que puxa o trio elétrico e dilui a experiência musical, narrativa, performática e espacial pela Avenida enquanto registra em tempo real esta grande performance para posteriormente reestrutura-la na edição do filme.

O trabalho também teve saída como um livro, numa tiragem de 100 exemplares numerados, por ocasião de uma exposição que buscava estabelecer relações e afinidades entre o trabalho de Barney e o de Bueys, no museu Guggenhein, na sua sede alemã, em Berlin, intitulada "All in the present must be transformed"(2006-2007). Embalados em um estojo de design elaborado por Barney, a caixa contenedora do volume é composta de uma folha de madeira pau-rosa e um suporte de poliuretano onde está gravado o desenho da árvore e das ferramentas de Ogum - ícones marcantes do trabalho - e postais que revelavam desenhos processuais e stills do orixá Ogum.

Se livro e filme podem ter trajetórias próprias, segundo o artista, somente no museu a exposição é capaz de encerrar o todo do trabalho de forma simbiótica onde escultura, imagens em movimento e o sistema de objetos são reunidos, destilando a narrativa e qualificando a arquitetura, não somente como uma de suas locações cinematográficas, mas também como escolha geográfica e parte essencial da obra, onde a estória se condensa e é narrada de forma a contribuir e absorver a 

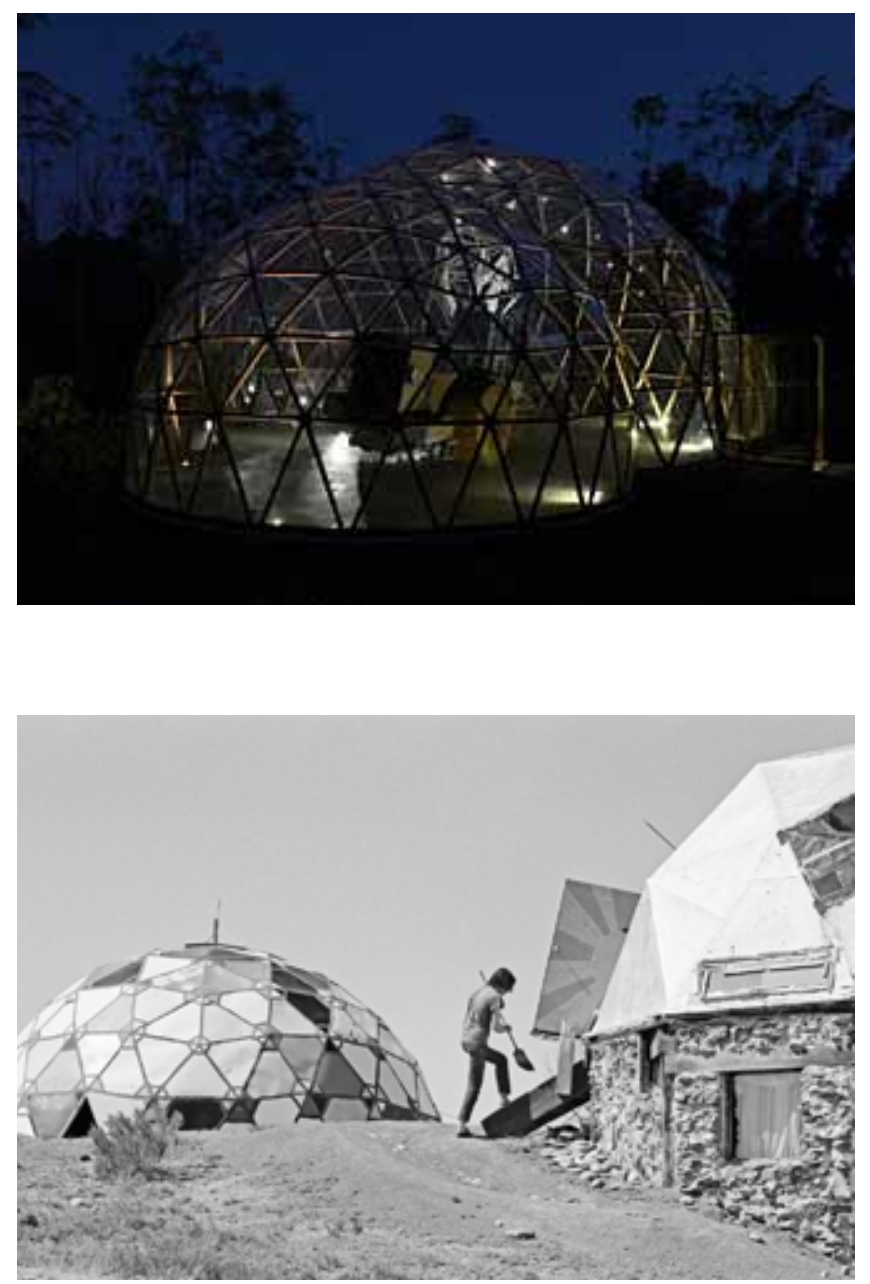

\section{figura 60}

Matthew Barney, Pavilhão De Lama Lâmina -2004/2009

(Inhotim, Minas Gerais)

\section{figura 61}

Drop-City-1969

(Colorado, Estados Unidos) 
carga emocional dos personagens ${ }^{146}$.

A escolha do local, em Inhotim, foi primordial para que o pavilhão resgatasse e concluísse a narrativa. Incrustado na mata nativa, o espectador é conduzido por uma trilha supostamente aberta pelo trator até a clareira, onde parece ter concluído seu trajeto para finalmente sua engrenagem travar-se em meio às duas cascas geodésicas (figura 60) que envolvem o trator-escultura.

A solução em cúpula geodésica inevitavelmente conecta "De Lama a Lâmina” à Buckminster Fuller, o que fornece mais elementos para engrossar o caldo de referências pop comuns à obra de Barney. As cúpulas geodésicas foram desenvolvidas pelo arquiteto-artistacientista norte-americano em 1940, e patenteada quatorze anos depois, projetando Fuller internacionalmente. Estas estruturas se mostraram extremamente flexíveis na sua apropriação técnica e ideológica, transitando do oficial e estabelecido ao alternativo, de abrigo oficial do departamento de defesa norte-americano, que a utilizou como ferramenta estratégica na ocupação territórios em escala militar e global, a símbolo dos acampamentos hippies da contracultura dos anos sessenta, tendo na Drop-City ${ }^{147}$ (figura 61) seu primeiro e grande exemplo, onde toda a aura da comunidade instalada em um grande acampamento em uma área rural refletia muito mais a retórica ecológica de seu inventor. Fuller é reconhecidamente um dos precursores das causas ecológicas, e suas especulações técnicas passavam por soluções para a gestão de recursos naturais ou possibilidades de se recomeçar a sociedade sob novas bases após um colapso ambiental acarretado pela equivocada gestão do planeta que naquele momento já

146 Barney diz: "The emotional weight in the story can be shared by the architecture and ladscape, and in that way, the emotional burden can be removed from the caracthers" ou " $\mathrm{O}$ peso emocional da estória pode ser partilhado pela arquitetura e a paisagem, e neste sentido, o fardo emocional pode ser retirado dos personagens" em entrevista concedida a Gerald Matt, diretor do Kunstahalle de Viena, por ocasião da inauguração da exposição "Cremaster", em Viena, em 2002, referindo-se à importância das locações nos diversos capítulos da obra - o estádio em Boise, Idaho, em "Cremaster 1", a Ilha de Man entre Irlanda e Escócia, em "Cremaster 4", a ópera de Budapest, em "Cremaster 5", e o Edifício Chrysler em Nova Iorque em "Cremaster 3".

147 A experiência de Drop-City e das cúpulas geodésicas como estrutura relacionada à contracultura norte americana é destrinchada por Fellicity Scott ao longo do capítulo 6 - "Revolutionaries or dropouts", no livro "Architecture or Techno-utopia, politics after modernism”. Cambridge, MIT Press, 2007. p. 39-54 
se direcionava para uma cultura de consumo e desperdício.

O discurso ecológico é também claramente o pano de fundo do enredo de "De Lama Lâmina", articulado por Barney ao processo criativo como a possibilidade de se resgatar a fé no equilíbrio da natureza ${ }^{148}$. Ogum destrói, mas sua ação prenuncia seu limite e esgotamento, enquanto Ossanha realiza através dos galhos o processo de cura. O trator abre a trilha e a clareira para ali ser recoberto pela cúpula, símbolo pop e contracultural, que espelha e mimetiza seu entorno, revelando através do vidro a estrutura construída pelo homem sobre a estrutura natural dos galhos. Ao mesmo tempo em que espelha a mata, sobrepõe imagens: a árvore mumificada no interior, é sobreposta à mata circundante, o nó triangular equilibrado nos galhos da árvore é sobreposto à estrutura geodésica do pavilhão.

O projeto do pavilhão realizado pelo estúdio de Barney (figura 62) contou também com a colaboração da arquiteta Paula Zasnicoff que, após a escolha do sítio pelo artista e a curadoria - que perambularam pela fazenda em busca de um local que reunisse as qualidades necessárias para sua implantação - passou ao desenvolvimento do projeto, o que envolveu uma delicada compatibilização da estrutura, pois, se a geodésica tornou-se $p o p$ nos Estados Unidos, tendo fácil reprodutibilidade com peças industrializadas, adaptá-la ao Brasil significou um intenso detalhamento de componentes e nós, inexistentes no mercado nacional (figura 63). A proporção do volume e a relação entre a intersecção dos domos e posicionamento do trator em seu interior receberam apenas uma interferência necessária: a marcação da entrada por um pórtico metálico que interrompe a malha triangular da estrutura para proteger a porta como beiral necessário e funcionar como barreira para a manutenção da climatização do ambiente.

148 No comunicado à imprensa para a divulgação do filme, Barney afirma: "a meditation on the creative process... a way to express a faith in the balances in nature... and through this faith being able to look at the world today without feeling hopeless." "Uma meditação sobre o processo criativo...uma maneira de expressar a fé no equilíbrio da natureza...e através desta crença ser capaz de olhar para o mundo hoje sem se sentir desesperançado." In: http:// henryart.org/mediathings/show/1239 consultado em 20-12-12. 


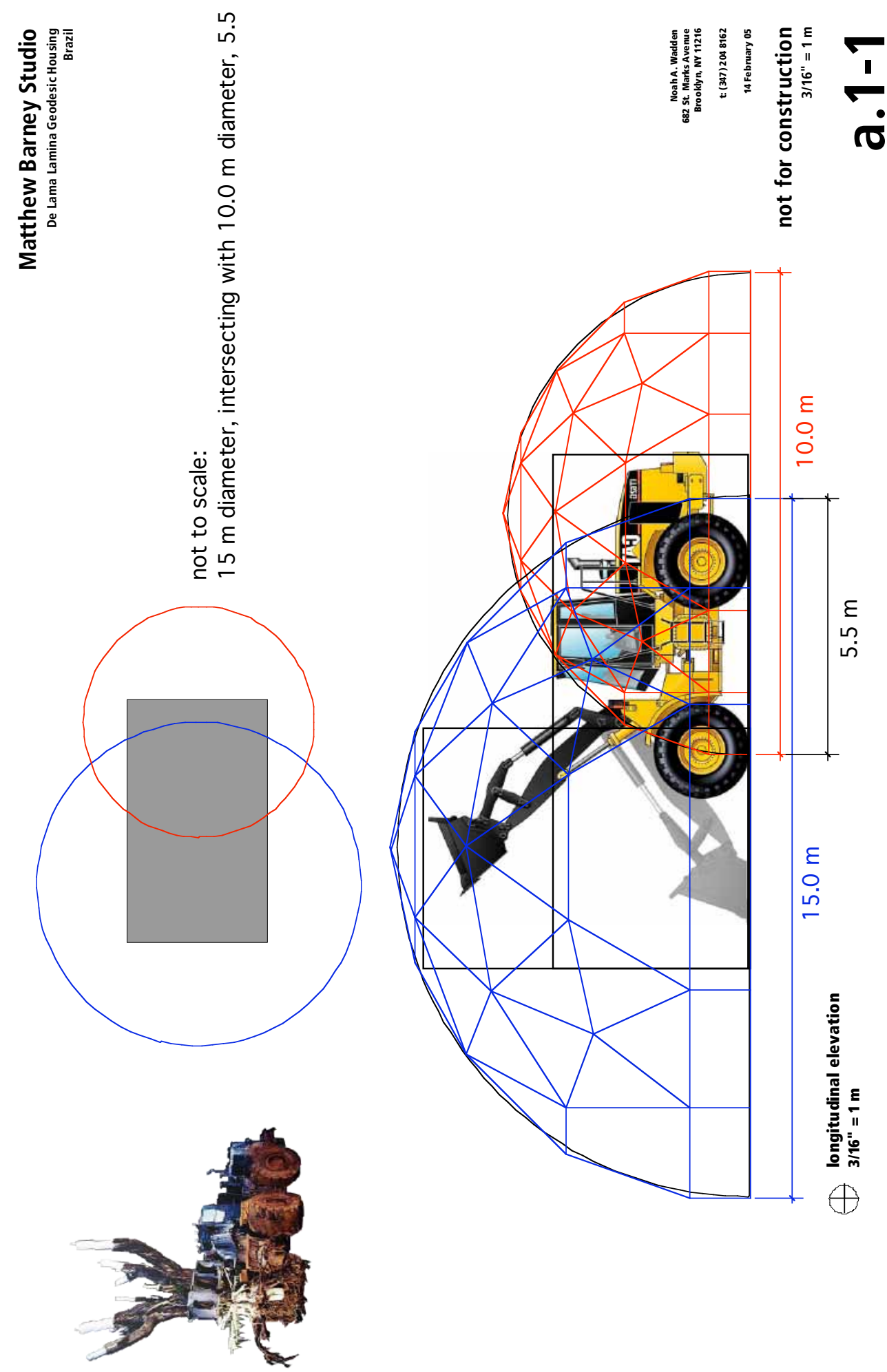

figura 62

Matthew Barney. Estudo preliminar para o Pavilhão De Lama Lâmina - 2005 

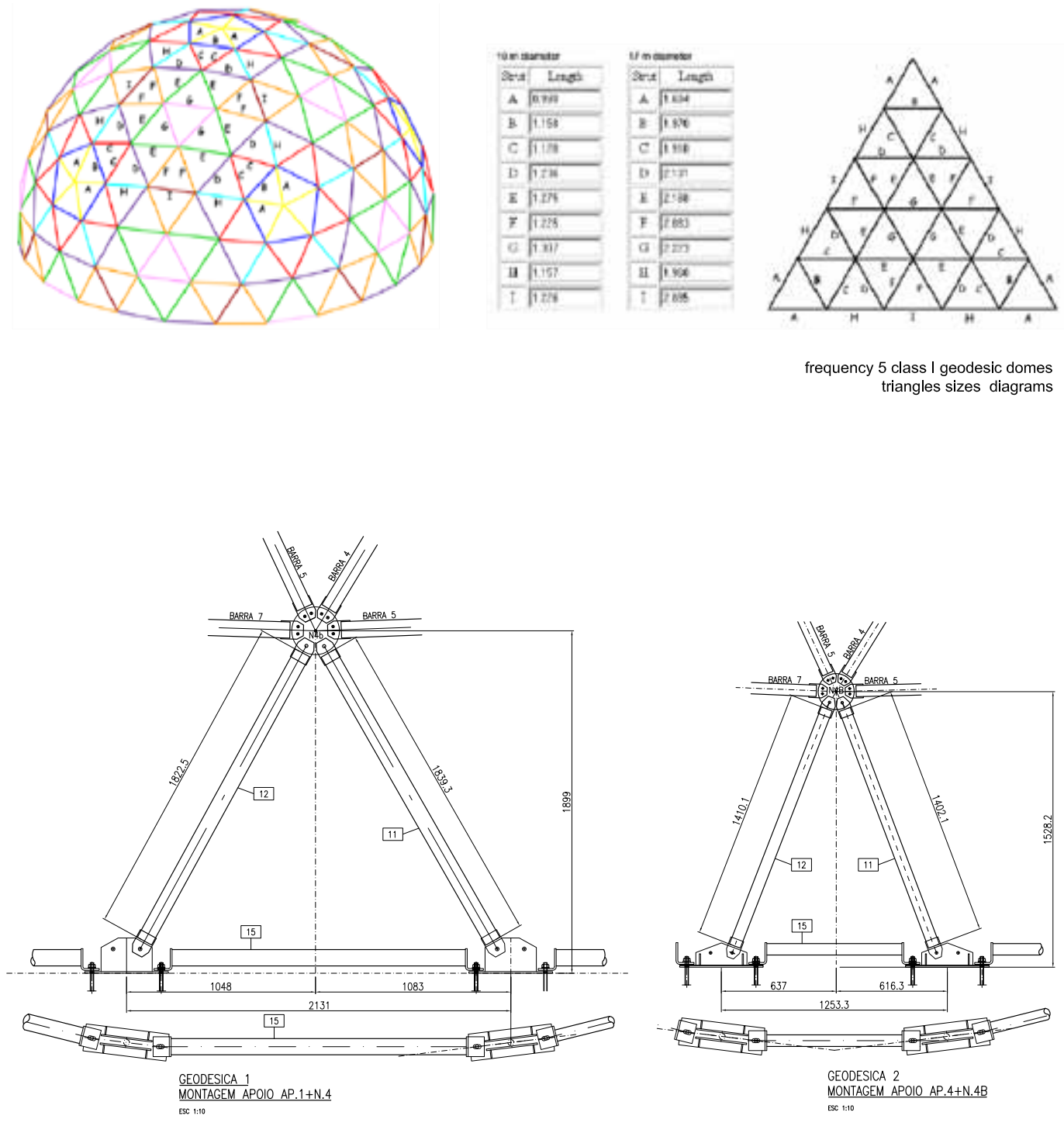

\section{figura 63}

Paula Zasnicoff/ Tensor Estrutura Especiais. Detalhes construtivos - 2008 


\subsection{Pavilhão Adriana Varejão}

Por fora, em meio a um recorte da mata mais fechada do parque, encontra-se um paralelepípedo de concreto pousado a meio caminho entre um espelho d'água, de recorte geométrico claramente demarcado, e a topografia reconstruída sobre um recorte pré-existente do terreno, em cujas faces, marcas das formas do concreto, remetem a uma parede de "azuleijões" descascada. Por dentro, uma promenade em que espaço e pintura se completam a cada mirada. Assim, o pavilhão se insere em meio à paisagem (figura 64) criando esta oposição entre forma construída e natureza, dentro e fora, reconstruindo um percurso ao longo das cotas no qual possibilita uma unidade entre o trabalho da artista e o do arquiteto, cada qual em seu território, porém em harmoniosa complementaridade.

Rodrigo Cerviño Lopez foi levado a Inhotim por Adriana Varejão e a parceria afinada entre os dois é consequência da amizade que já havia rendido também um projeto anterior, o ateliê da artista, projetado pelo arquiteto no Rio de Janeiro ${ }^{149}$. Desta afinidade surge o pavilhão criado para abrigar de forma permanente os trabalhos ali expostos e que, ainda hoje, reverbera em Inhotim um caso isolado, de perfeita relação entre arte e arquitetura, pois não se trata de somente resolver a mediação da obra artística, nem tampouco de ser a obra de arte, mas sim de potencializar sua apreciação tornando-se parte essencial desta experimentação em processo de rebatimentos múltiplos numa via de mão dupla.

Para se entrar no intrigante sólido paralelepípedo - volume resultante da grande galeria de exposição da obra "Celacanto Provoca Maremoto" (2008)- é preciso se deixar levar pelo percurso demarcado sobre o espelho d'água em trajetória diagonal, que convida a uma

149 O primeiro trabalho em parceria é o desenho gráfico do catálogo da exposição "Azulejões", em 2000 no CCBB desenvolvido pelo arquiteto que é também designer gráfico. 


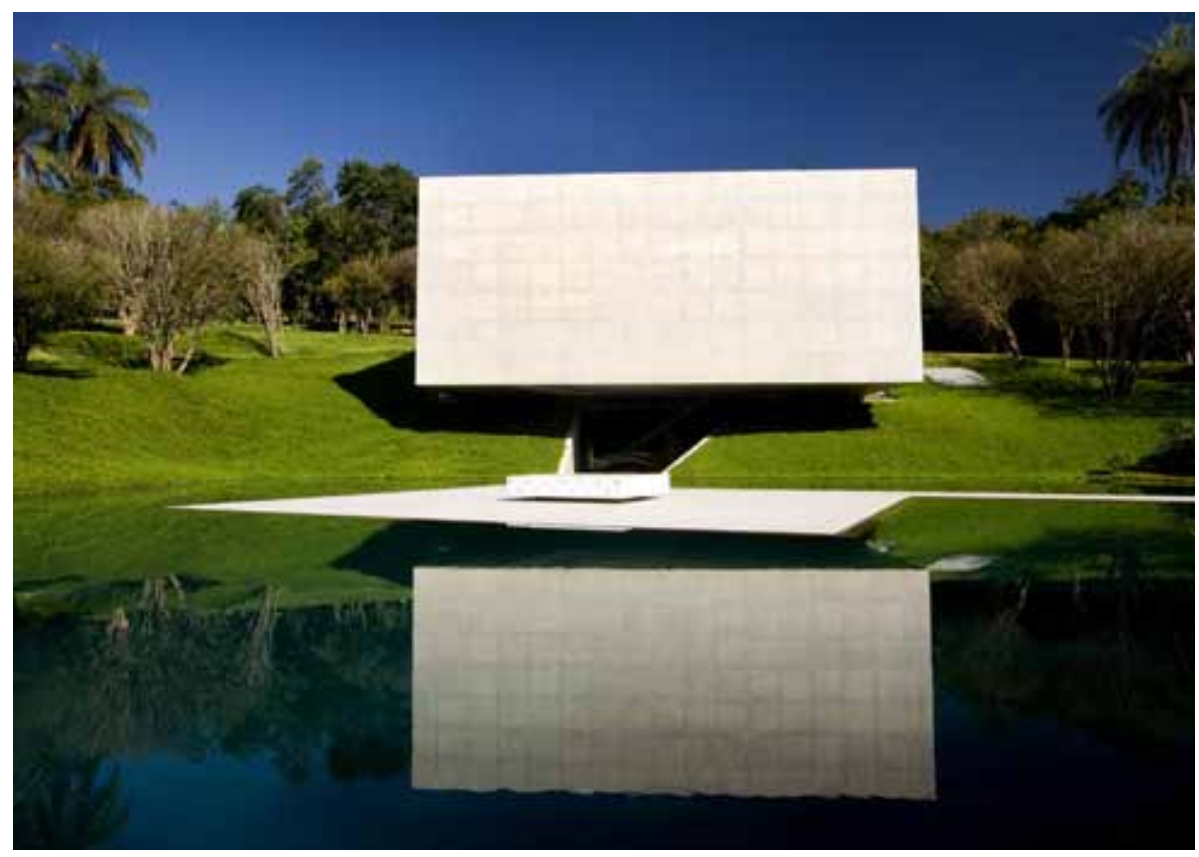

\section{figura 64}

Rodrigo Cerviño Lopez. Pavilhão Adriana Varejão - 2008.

(Inhotim, Brumadinho, Minas Gerais) 
primeira parada na praça quadrada onde, ao centro, o banco levemente "solto" do piso de cimento foi inserido pela artista para que, revestido de azulejos brancos com a representação de plantas alucinógenas, e em contraste com o azul profundo da água ao redor - fruto do reflexo da cor com que é tratado o fundo do espelho d'água que também tem o tom essencial dos azulejos-, revelasse o ritual de preparação com a obra "Panacea Phantastica" (2003-2008), que proporciona a vertigem esperada para fruição das obras.

A primeira obra, ao entrar no pavilhão, é "Linda do Rosário" (2004 - figuras 65 e 66), um misto de escultura e pintura, onde a tela revela sua qualidade de pele que imprime a malha racional e envolve a carne, natureza pulsante e irracional, preenchendo desordenadamente este miolo recoberto por faces azulejadas, conformando um corte ou ruína que, segundo Paulo Herkenhoff, simboliza a terra revolvida e escavada para a entrada e implantação do volume ${ }^{150}$. O primeiro piso, cravado na encosta de forma irregular, contribui para sensação de suspensão do prisma puro superior, e, ao destacar-se da topografia, possibilita a entrada da luz natural que faz saltar a volumetria da obra. Posicionada sob as vigas de estruturação da pele de concreto, o oco deixado pela volumetria, desperta na artista o desejo de produzir uma nova obra relacionada à arquitetura e, assim, a série "Carnívoras" (2008 - figura 65) - última obra acrescentada ao prédio, que apresenta uma série de pinturas fixadas no teto como "almofadas de forro" - é encaixada com precisão na modulação da nervura da laje, representando plantas carnívoras e, assim como as plantas alucinógenas no banco do exterior, remetem a um trabalho de registro exploratório naturalista.

A azulejaria é elemento que perpassa as obras expostas no pavilhão e é presente em boa parte da produção de Adriana Verejão, que assume este elemento como referência barroca das construções coloniais onde o azulejo português era utilizado como revestimento e decoração nos edifícios de grande importância. Esta mesma tradição permanece arraigada e é traduzida como primeiro grande exemplo de síntese das artes modernas no Brasil, na equipe liderada por Lúcio

150 In: LOBATO - CAMPOLINA - MAGALHÃES. Adriana Varejão. Pavilhão (2008). DVD. 

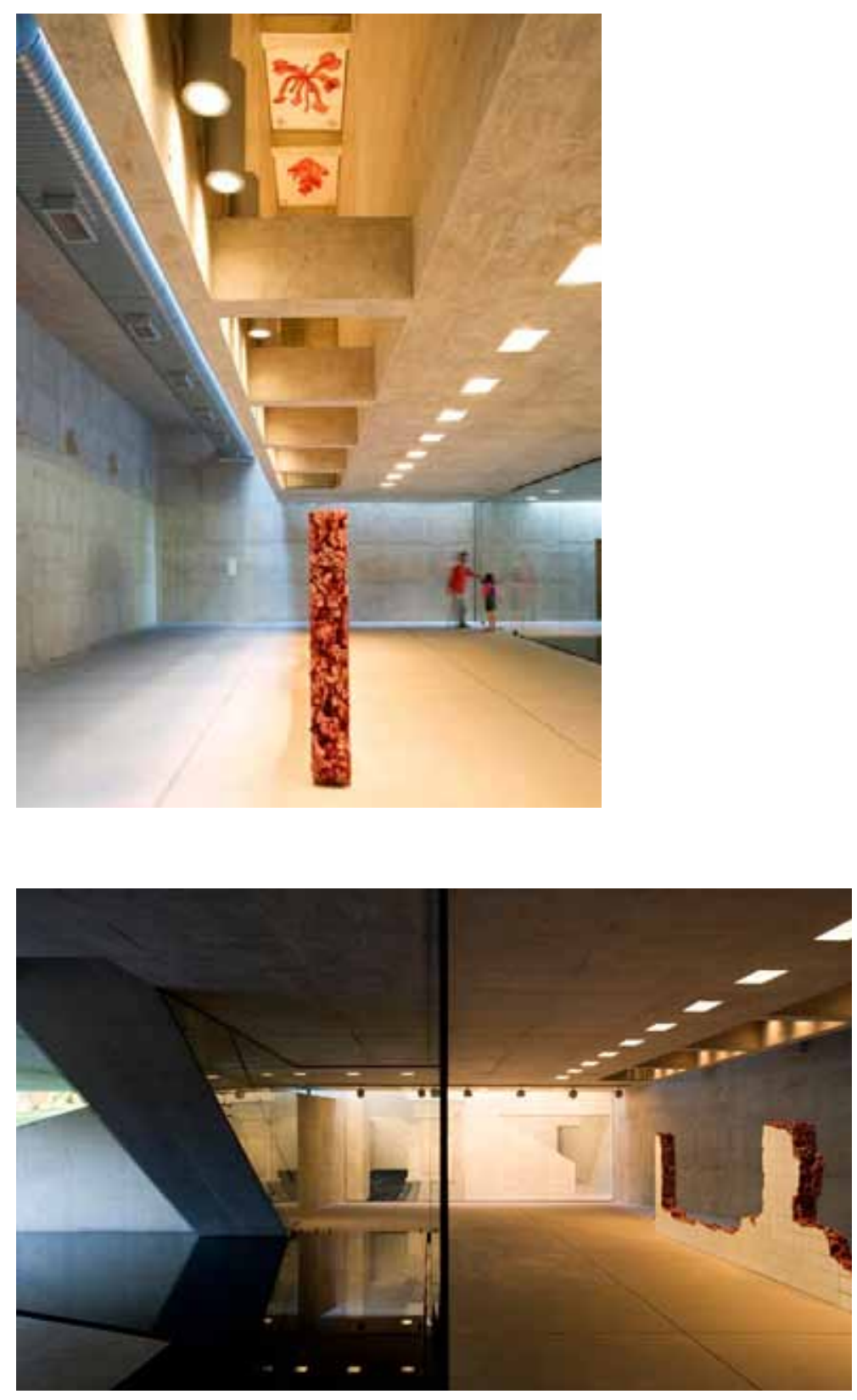

\section{figura 65}

Adriana Varejão. "Linda do Rosário" - 2004 e "Carnívoras"- 2008

figura 66

Adriana Varejão. “Linda do Rosário” - 2004 e "O Colecionador” - 2008.

(Inhotim, Brumadinho, Minas Gerais) 
Costa no projeto do Ministério da Educação e Cultura (1936-42), onde Portinari produz o grande painel que reveste o volume curvo sob os pilotis do edifício ${ }^{151}$. Nas obras de Adriana Varejão os azulejos também são referência das construções comuns onde é utilizado com caráter funcional - são botecos e açougues, cozinhas e banheiros na privacidade das casas, ou a assepsia dos hospitais, salas de cirurgia, e laboratórios -, mas é em uma de suas saunas, sempre vazias e fechadas, que a espacialidade da pintura complementa-se à do pavilhão e assim “O Colecionador"(2008 - figura 66), produzido para ocupar toda a parede lateral do salão de entrada, produz um efeito de trompe l'oeil que absorve o espectador para seu contínuo sensorial e psicológico onde o olhar se perde na malha da perspectiva de linhas de azulejos. A água da sauna, retratada na pintura, é de cor azul profundo e a malha da imagem é distorcida pela refração da piscina. Num efeito duplicado, o espelho d'água que invade a galeria e reflete a pintura mais uma vez retorcendo-a. No vídeo “Adriana Varejão - Pavilhão” (2008), produzido pelo Inhotim, a vemos trabalhando in loco, pintando cada azulejo da obra "individualmente como um monocromo em si" 152 que se compõe num todo de variações de cinza, como uma janela que se abre partindo do concreto aparente da galeria para o interior da sauna.

A escada de acesso ao segundo piso parece colada ao volume suspenso ${ }^{153}$ e convida a subir como que flutuando sobre a água para assim conduzir ao centro do salão superior onde "Celacanto Provoca Maremoto" ${ }^{154}$ (2008- figura 67), que ocupa as quatro faces, três delas contíguas, descola-se do piso liso de um branco reflexivo e do teto escuro que desaparece, envolvendo o espectador em sua turbulência de

151 Esta tradição manifesta-se em diversos exemplos da arquitetura nacional onde se destaca o trabalho de Athos Bulcão e seus diversos painéis geométricos conformados pela recombinação aleatória das partes aplicadas de forma livre pelos operários durante a obra resultando em um todo final.

152 Fala de Paulo Herkenhoff narrando o percurso do vídeo pela obra. In: LOBATO CAMPOLINA - MAGALHÃES. Op. cit.,.

153 O volume está apoiado em quatro pontos, assim como a escada também toca o chão, mas a distribuição das alvenarias e reconfiguração da encosta, esconde visualmente a estrutura, sugerindo o efeito de misteriosa suspensão exaltado pelo ponto em que o volume aflora em balanço.

154 Título remete a série de grafites atribuídos ao jornalista Carlos Alberto Teixeira que, na década de 70, espalhou a frase nonsense pela zona sul carioca causando intrigante repercussão no auge do período militar. 


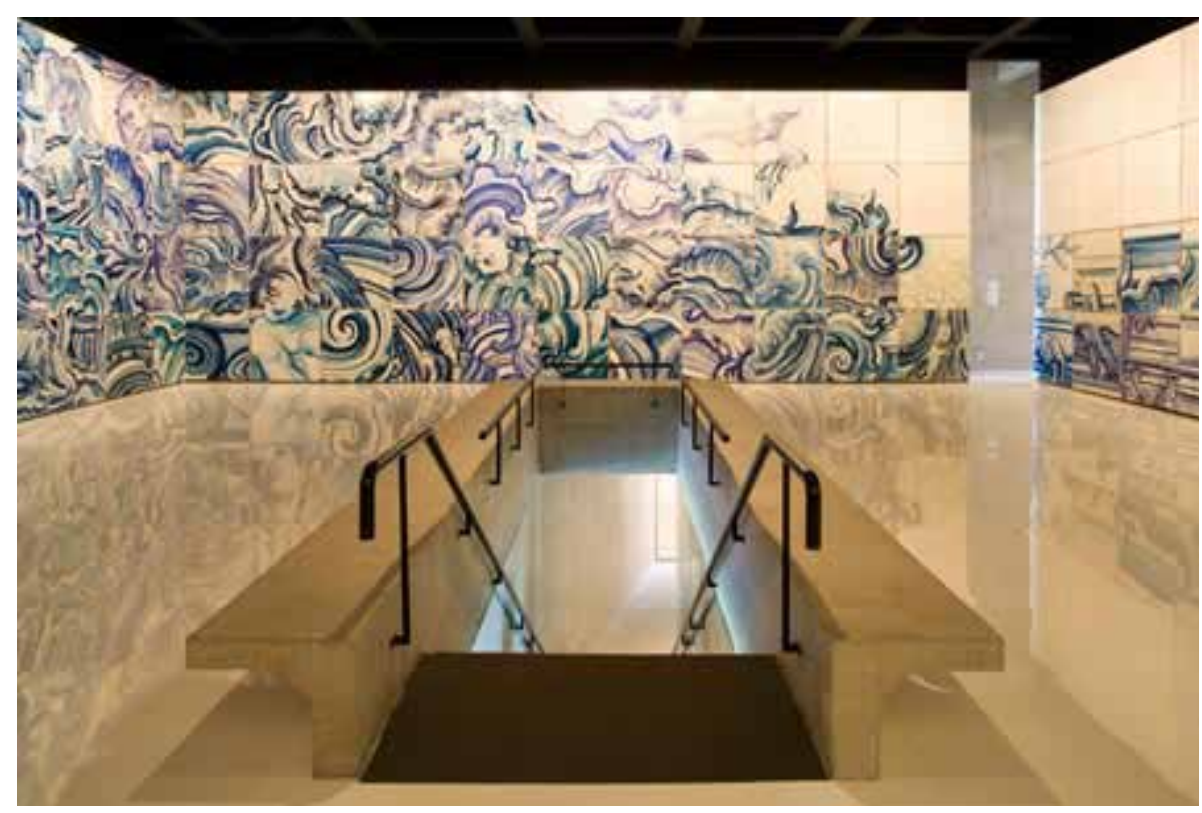

\section{figura 67}

Adriana Varejão. "Celacanto Provoca Maremoto" - 2008

(Inhotim, Brumadinho, Minas Gerais) 
ondas revoltas e referências pictóricas rococós. Unidade e todo agora se organizam de fato como peças independentes, onde cada uma das 184 telas é um azulejão, de $1.10 \mathrm{~m}$ por $1.10 \mathrm{~m}$, recombinada na malha, sendo simultaneamente parte e todo disjuntivo, uma vez que as imagens não se complementam, mas explicitam sua incongruência num processo que, segundo a artista, revela a intenção premeditada de "construção de uma desconstrução".

Completando o circuito, uma rampa que envolve a grande galeria conduz o público ao terraço-jardim, onde os bancos são mais uma vez revestidos pela azulejaria branca, desta vez com espécies de pássaros em evidente relação com a natureza avistada a partir do mirante e, deste ponto, pela passarela, é possível retomar o contato com o terreno pela sua cota mais alta e seguir o percurso, ou mesmo, recomeçar novamente e infinitamente esta experiência sensorial que Herkenhoff precisamente qualifica de sublime moderno. 


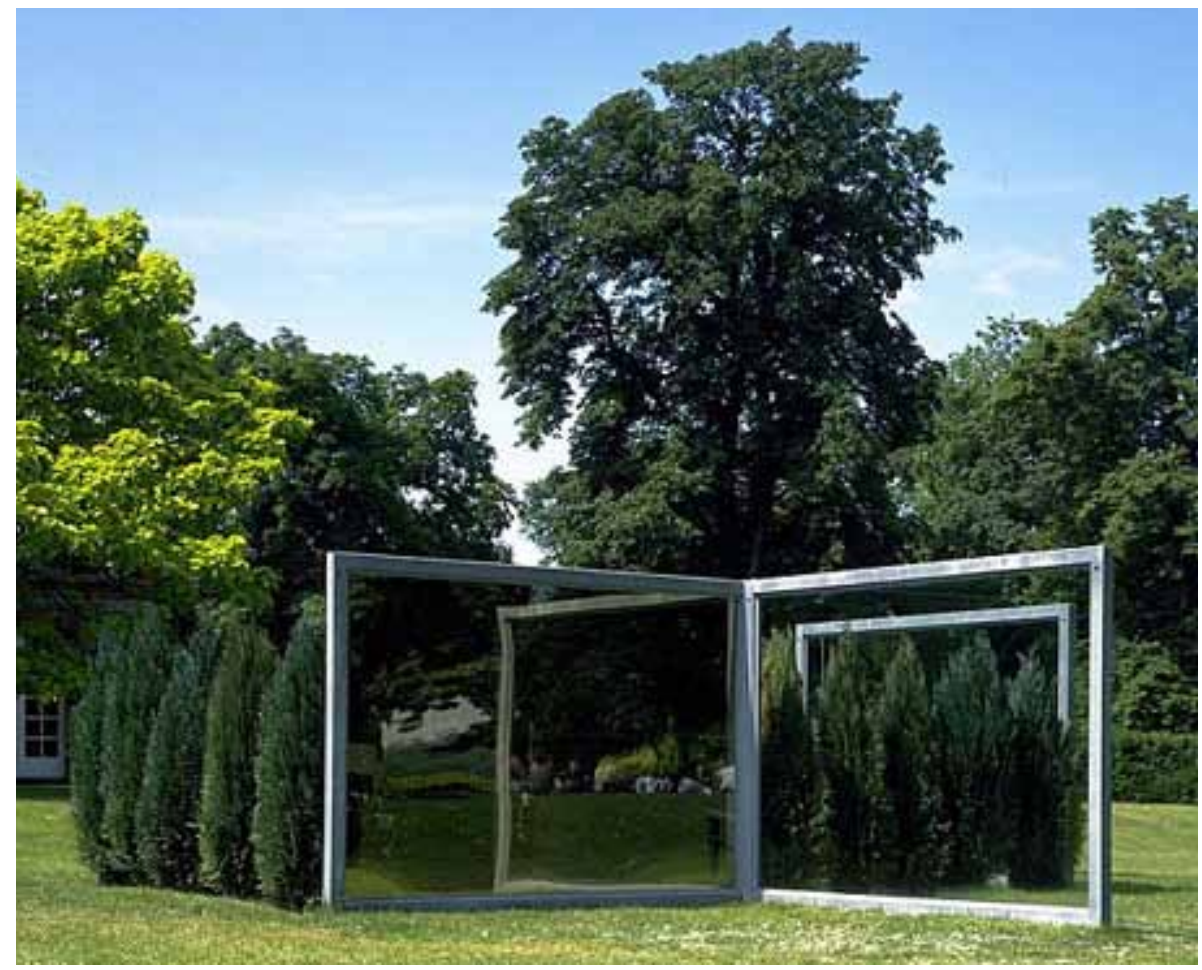

\section{figura 68}

Dan Graham. "Two Way Mirror and Hedge Labyrinth" - 1989

(Serpentine Gallery, Londres) 


\section{Serpentine Galery}

\subsection{O programa de pavilhões, arquitetura e curadoria.}

A galeria Serpentine, localizada nos jardins de Kensington, em Londres, desde 1970 abriga exposições de arte moderna e contemporânea e, a partir do ano 2000, iniciou um programa de pavilhões temporários que anualmente convida um arquiteto ou escritório para desenvolver um projeto que ocupe o jardim adjacente ao bloco principal ${ }^{155}$ durante quatro meses ao longo do verão e outono ${ }^{156}$.

A curadora e diretora da instituição, Julia Peyton-Jones, estabelece uma linhagem de obras presentes em exposições abrigadas pela galeria que, a partir dos anos 90, apontaram para uma constante presença da arquitetura, que era confrontada pelo trabalho dos artistas, mas credita a Dan Graham o primeiro indício que levaria à criação do programa de pavilhões, quando em 1992, um de seus pavilhões, ao integrar a exposição "Like nothing else in Tenessee",- voltada para um entendimento da arquitetura pela arte -, foi instalado nos jardins (imagem 68). O segundo estopim viria da necessidade de reforma da galeria que levou a direção a acompanhar de perto o processo do projeto e da obra, estreitando a compreensão de que a interação entre arquitetos e a instituição artística poderia ampliar o debate sobre a arquitetura contemporânea, pouco conhecida e aceita pela população londrina. Além destes fatores, a limitação espacial durante o período da reforma levou a Serpentine a comissionar trabalhos que pudessem acontecer em seu

155 A Serpentine Gallery ocupa um edifício vitoriano do século XIX inicialmente destinado ao laser em meio ao parque, ou seja, é em si um exemplo de pavilhão de jardim vitoriano.

156 Originalmente, estruturas temporárias não eram autorizadas no jardim - que fazem parte do parque real - por período superior a trinta dias, mas a partir de um entendimento da importância e originalidade da proposta, que visa proporcionar aos cidadãos ingleses a possibilidade de vivenciar o melhor da arquitetura contemporânea em seu território, a autorização foi concedida, estendendo o prazo para três meses de permanência. 
jardim, como o projeto de Tadashi Kawamata que ocupou do canteiro de obras, trabalhando com materiais de construção de forma a executar um tapume que retomava características do edifício. Assim, a partir da experiência de aproximação de artistas com os potenciais expressivos da arquitetura ao longo de uma década, somada à necessidade de adequação de um programa expositivo ao longo de um período de reestruturação do edifício e ainda à necessidade de se ampliar o espaço relativamente pequeno da galeria em dias de grandes eventos, resulta, a partir do ano 2000, a sistemática construção de coberturas temporárias para a realização de eventos durante o verão.

Desde então, já são doze anos de programa, que convidou em ordem cronológica: Zaha Hadid, 2000; Daniel Libeskind e Arup, 2001; Toyo Ito e Cecil Balmond com Arup, 2002; Oscar Niemeyer, 2003 ${ }^{157}$; MVRDV com Arup, 2004 (não realizado); Álvaro Siza e Eduardo Souto de Moura com Cecil Balmond, Arup, 2005; Rem Koolhaas e Cecil Balmond, com Arup, 2006; Olafur Eliasson e Kjetil Thorsen, 2007; Frank Gehry, 2008; Kazuyo Sejima e Ryue Nishizawa, SANAA, 2009; Jean Nouvel, 2010; Peter Zumthor, 2011, Herzog e de Meuron + Ai Weiwei , 2012 e Sou Fujimoto, que apresentou seu projeto para ser construído no verão de 2013.

A experiência deste programa fomenta a retomada da discussão do pavilhão como forte ponto de contato entre arte e arquitetura, manifesta tanto na aproximação de arquitetos com procedimentos artísticos resultantes de experimentações formais em busca de obras únicas, onde a relação com o funcionalismo é anulada pela ausência do programa quanto na dinâmica de aquisição destas obras - e suas possíveis edições, pois são pensadas para o desmonte assim como para uma reprodução em pequena escala - por colecionadores particulares ${ }^{158}$ e instituições que vêm investindo na formação de coleções de pavilhões, adquiridos ou

157 Cabe notar que Oscar Niemayer destoa do perfil contemporâneo da lista, sendo o único grande arquiteto moderno a ter participado do programa.

158 A composição público-privada que financia o programa é duramente criticada por Andrea Phillips - professora do departamento de arte em Goldsmiths College, Londres. Ela parte deste exemplo para explicitar a contraditória postura de programas públicos que se favorecem da especulação de capital. In: Pavilion Politics. 2010, p.105. 
comissionados.

Os pavilhões da Serpentine Gallery colocam em evidência a arquitetura na agenda de uma instituição tradicionalmente voltada a arte contemporânea, que evita em seu programa de arquitetura, estabelecer parcerias entre artistas e arquitetos ${ }^{159}$ como forma de ressaltar que não se trata de criar um espaço para a exibição de uma determinada obra de arte ou ampliação para acomodação de uma exposição, mas sim de "trazer para a mesa uma liberdade sem paralelo para os arquitetos. O resumo é muito simples: tudo o que solicitamos é que o pavilhão possa ser um exemplo de suas linguagens arquitetônicas." 160

Assim, a tradição arquitetônica do pavilhão como arquitetura autorreferente redireciona a forma de se entender, num contexto contemporâneo, tanto o papel de uma curadoria voltada para arquitetura quanto o papel das exposições de arquitetura dentro de Instituições de arte, rompendo com o modelo moderno de exibição de arquitetura firmado pelo Moma novaiorquino ao longo do século $\mathrm{XX}$, e definindo um espaço de convergência entre a arquitetura dos pavilhões e a exposição da arquitetura per se.

Por outro lado, um programa de pavilhões como o da Serpentine, reflete o substancial aumento de interesse na arquitetura uma vez que, como afirma Silvia Lavin em artigo recente na revista Artforum: "hoje, temos de acrescentar que o mundo é uma exposição e, especificamente, uma exposição de arquitetura." 161

Se o mundo é hoje uma grande exibição de arquitetura, o que

159 A possível contradição na edição de 2007, realizada pela dupla Kjetil Thorsen, arquiteto norueguês fundador do escritório SNOHETTA e Olafur Eliasson, artista dinamarquês, é rebatida pela curadoria com o argumento de que Eliasson possui um estúdio multidisciplinar e trabalhou no pavilhão como arquiteto, mobilizando o setor de arquitetura de seu estúdio. Não houve intenção de se criar um edifício que abrigasse uma obra e sim uma parceria entre arquitetos resultando num pavilhão. In: JODIDIO. Colonia: Serpentine Gallery Pavilions. 2011, p.18.

160 "...bring to the table an unparalleled freedom for architects. The brief is very simple: all we ask is that the pavilion might be na example os their architectural language." Ibidem, p.16.

161 "Today we must add that the world is an exhibition, and specifically, an architectural exhibition.”In: LAVIN. 2010, op. cit., p.8. 
revela o atual estado de hipertrofia da arquitetura ${ }^{162}$, com seu esplendor formal impulsionado pelas inovações e aportes tecnológicos, este destaque reverbera nas instituições que, cada vez mais, dão destaque à arquitetura e a sua relação com as artes como questão crucial para a compreensão contemporânea. Neste processo criam-se programas voltados exclusivamente à arquitetura que alçam curadores - figuras antes restritas ao universo artístico - a um papel de destaque na cena arquitetônica.

A importância da curadoria no programa de pavilhões da Serpentine Gallery é consolidada com a parceria entre Julia PeytonJones - diretora e criadora do programa - e Hans Ulrich Obrist figura com forte presença midiática na última década, contribuindo em grande medida para um entendimento e popularização do trabalho do curador - quando, este último, passa a fazer parte da instituição, em 2006, como codiretor de exposições e de programas e diretor de projetos internacionais.

Segundo Sylvia Lavin, Hans Urlich Obrist tem sido capaz de gerar uma mudança no status do curador dentro do sistema de produção e consumo cultural, onde os curadores tornaram-se os responsáveis pela encenação de situações e experiências que se configuram como "o trabalho". Assim, afirma: "exposições estão efetivamente colocando um fim em qualquer distinção útil entre "o trabalho" e "o não-trabalho" e alterando o papel do curador, daquele que se preocupa com o trabalho de outros para aquele que produz trabalho." ${ }^{163}$

Este entendimento já era mais poroso no universo artístico uma vez que diversos artistas fazem de seu trabalho a manipulação e seleção de obras de um arquivo ou coleção, mas, para a arquitetura, esse reconhecimento se dá predominantemente a partir do pósestruturalismo, que partindo da distensão da literatura, disparou

162 Para um desenvolvimento deste assunto, ver a tese de doutorado de Guilherme Wisnik: "Dentro do nevoeiro, diálogos cruzados entre arte e arquitetura contemporânea" (2012).

163 LAVIN. Op. cit. p.6. 
também a flexibilização e expansão do que é entendido como trabalho arquitetônico, marcando uma distinção entre arquitetura e construção que permite um entendimento de que texto, desenho e exposição sejam também reconhecidos como trabalho afeito ao campo disciplinar arquitetônico. ${ }^{164}$

Enquanto o sistema conformado por galerias e museus funciona como regulador do mercado de arte, mediando relações entre produção e consumo, o mesmo não ocorre com a arquitetura, onde revistas e periódicos - elementos autônomos não relacionados ao sistema - parecem ter tido maior importância para a promoção de ideias, para a comercialização e o consumo de modelos arquitetônicos. O fenômeno do museu de arquitetura - a exemplo do NAI holandês -, ou da exposição de arquitetura em galerias, são recentes e ainda com contornos indefinidos ${ }^{165}$. O mesmo se aplica à curadoria de arquitetura e, neste sentido, Obrist demonstra uma aguçada mirada que se desdobra de seu desejo de se aproximar de artistas e arquitetos de forma a possibilitar a realização de seus projetos. Em suas atividades, aproxima a arquitetura da arte, assim como busca uma inserção mais enfática da arquitetura na esfera cultural, seja pelas suas maratonas de entrevistas com intuito de mapear o conhecimento polifônico de uma cidade de maneira a criar uma imagem sintética do lugar ao longo de vinte e quatro horas de conferências consecutivas ${ }^{166}$ - atividade que Obrist não dissocia de sua prática como curador e que entende como teste dos limites do museu -, ou pelas suas exposições onde convida artistas a trabalharem em locais distantes das instituições consagradas, confrontando a arquitetura de lugares como a Casa de Vidro, de Lina Bo Bardi, com obras produzidas especificamente para serem expostas nessa arquitetura.

164 Ver o capítulo 2 desta dissertação, p. 43.

165 Os temas relativos à mediação e reprodução, assim como as relações de produção e consumo da arquitetura, são desenvolvidos por Beatriz Colomina no artigo "Architectureproduction" originalmente publicado como introdução do livro de mesmo nome e compilado no livro "This is not architecture”. RATTENBURY(org.). 2002, p.207-221.

166 O mesmo esforço foi realizado para mapear o movimento Metabolista no Japão, entrevistando todos os fundadores e arquitetos que fizeram parte do grupo ao longo de três meses, buscando, em meio a sua complexidade, "encontrar" o movimento. In: OBRIST, 2006,p.112. 
Se exposições são, por natureza, dispositivos temporários, no caso do pavilhão Serpentine todo o processo é bem dinâmico - ao contrário do tempo estendido comum à arquitetura ${ }^{167}$ - e envolve equipes que devem colaborar e viabilizar o projeto ao longo de seis meses de intenso trabalho entre o anúncio do projeto e sua inauguração ${ }^{168}$. Os arquitetos que são comissionados para participar do programa não passam por processo de seleção ou concurso, e são escolhidos pelo corpo curatorial e diretoria ${ }^{169}$ segundo o critério estabelecido: não ter ainda construído na Grã-Bretanha e apresentar uma produção que represente significativa contribuição para seu campo disciplinar.

Embora em concordância com a premissa do programa, de apresentar ao público local o melhor da produção contemporânea internacional, alguns paradoxos podem ser salientados. O primeiro diz respeito à própria relação pavilhão-exposição que acaba por ressaltar a importância da construção como fato arquitetônico e a experimentação tecnológica estrutural como essência da forma arquitetônica ${ }^{170}$. Destaca-se neste sentido a participação do engenheiro Cecil Balmond e de sua equipe da Arup em praticamente todas as edições - inclusive como coautor em algumas edições. O segundo diz respeito ao processo de seleção, uma vez que, se considerado o declarado caráter experimental do programa, ampliado pela efemeridade das estruturas, ao priorizar a escolha de arquitetos já consagrados, o resultado é por vezes esmaecido frente ao conjunto da obra destes arquitetos. Este

167 Embora esta percepção de uma aceleração cada vez maior nos processos de projeto e construção seja bem explicitado por Rem Koolhaas que em entrevista a Obrist em 1998 se refere a "cidade chinesa" como fenômeno replicado em toda parte do planeta que sacrifica sua autenticidade em detrimento da velocidade de sua expansão. In: OBRIST,2010, vol. 3 p.66.

168 O único pavilhão que não pode ser viabilizado por questões técnicas foi a proposta do escritório holandês MVRDV em 2004 que recobriria a galeria Serpentine com uma montanha que em muito se aproxima do conceito de "The Last Land" (2005), de Hans Schabus na $51^{\circ}$ Bienal de arte de Veneza. Ver o capítulo três desta dissertação,p.76-77.

169 "We do not set up a competition, as would be the case wit architectural projects, because the decision is a curatorial one." "Nós não organizamos um concurso, como normalmente com projetos de arquitetura, porque a decisão é da curadoria." In: JODIDIO. op. cit. p. 14

170 "I don't make a distinction between skeletal structure na architectural form." "Não faço distinção entre esqueleto estrutural e forma arquitetônica", afirma Cecil Balmond. PEYTON-JONES/ OBRIST. 2006, p.31. 
é claramente o caso dos pavilhões projetados por Oscar Niemeyer

e Frank Gehry, dois arquitetos que já produziram ao longo de suas carreiras obras de grande impacto, e possuem uma vasta produção de obras associadas a um caráter experimental e subjetivo. Cotejar o museu de Bilbao ao pavilhão de Gehry ou o museu de Niterói ao pavilhão de Niemeyer revela uma contradição no discurso dos curadores do programa, uma vez que estes grandes arquitetos são justamente reconhecidos por sua ousadia, e não haverá de ser o pavilhão Serpentine que necessariamente os proporcionará condições únicas de experimentação.

A invenção arquitetônica não significa um atrelamento às condições particulares do programa Serpentine - a ausência de programa, a temporalidade e o orçamento garantido, comissionado por um museu interessado na experimentação de uma obra de arquitetura única, produzida por um reconhecido arquiteto - mas, certamente, instiga a subjetividade de boa parte dos participantes a projetar de forma a se aproximar de procedimentos artísticos. Assim, a partir da análise de três de casos, selecionados por resultarem em arquiteturas mais próximas do que poderia ser reconhecido como uma instalação artística, busca-se desvelar nos pavilhões Serpentine um recorte capaz de sinalizar uma significativa expansão de limites disciplinares da arquitetura contemporânea por parte de três escritórios participantes do programa: Rem Koolhaas(OMA) em parceria com engenheiro Cecil Balmond (2006), SANAA (2010) e Herzog e de Meuron juntamente com artista/arquiteto Ai Weiwei (2012). 


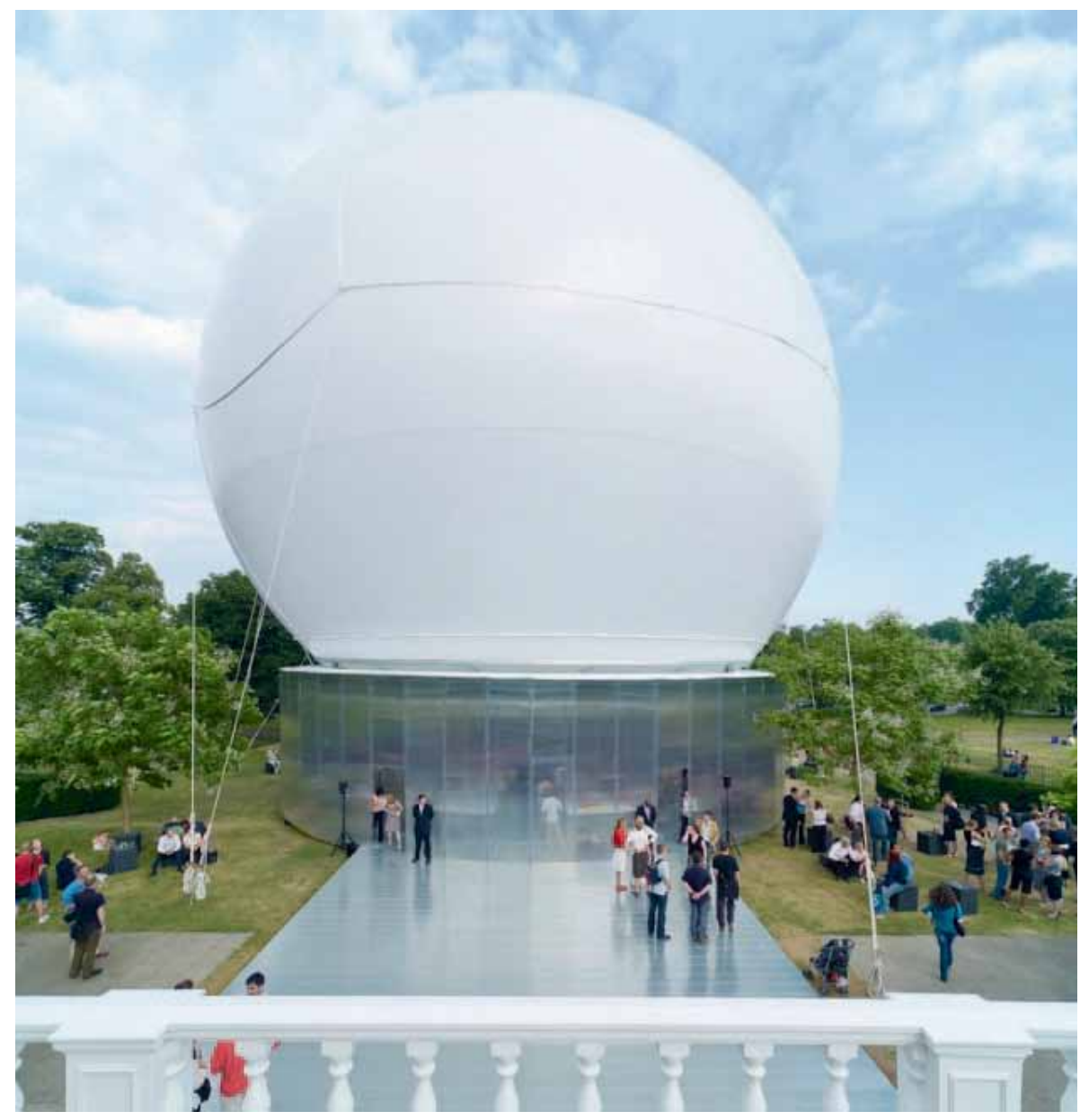

figura 69

Rem Koolhaas e Cecil Balmod. Pavilhão Serpentine - 2006

(Serpentine Gallery, Londres) 


\subsection{Rem Koolhaas e Cecil Balmond - 2006.}

O projeto de Rem Koolhaas - arquiteto holandês vencedor do prêmio Pritzker em 2000 - e Cecil Balmond - engenheiro-arquiteto nascido no Sri Lanka e radicado na Inglaterra - para o pavilhão Serpentine Gallery articula dois elementos em uma composição que ocupa o terreno de forma concisa, e com geometria simples (figura 69). O primeiro é numa calota, de dezoito metros de diâmetro por seis metros de altura, acomodada sobre uma plataforma levemente elevada do solo de onde partem os dois acessos para o público em quadrantes opostos - um relaciona-se com a via de circulação do parque e outro com uma das entradas laterais da galeria principal. A calota é construída em uma camada dupla e concêntrica de policarbonato translúcido, e é estruturada por uma delicada esquadria de alumínio, interrompida de quando em quando em alturas diversas para gerar as entradas e acomodar o pequeno programa que ocupa este espaço intersticial: os balcões do café, a chapelaria e equipamentos técnicos(figura 70).

O segundo elemento é o grande responsável pela forma ovóide que caracteriza o pavilhão: uma grande cobertura em poliéster de algodão revestido, que foi especialmente confeccionada para o projeto e inflada com uma mistura de gás hélio e ar pressurizado. O Cosmic Egg, como o denomina Balmont, atinge cinco metros de altura e se sobrepõe à calota que lhe serve como suporte (figura 71), sendo capaz de se soltar até dez metros acima do solo e com isso controlar a ventilação e iluminação do salão em acordo com o clima ameno do verão e outono inglês. A base do inflável é coroada por uma estrutura quadrada que se encaixa perfeitamente na estrutura de policarbonato do salão e garante o pé-direito interno sem qualquer variação resultante de uma deformação do balão.

Thomas Demand, que naquela ocasião ocupava o bloco principal 

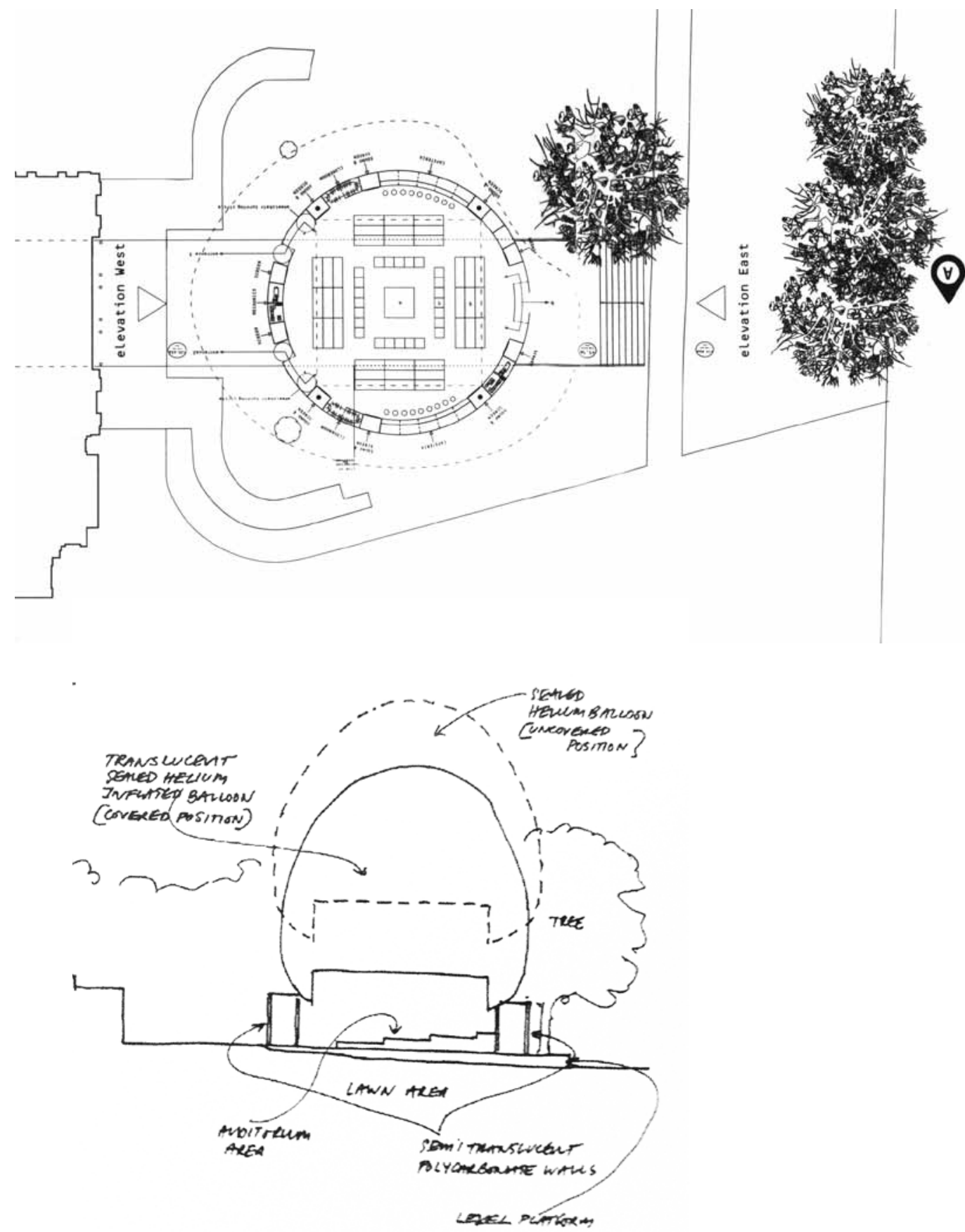

figuras 70 e 71 .

Rem Koolhaas e Cecil Balmod.

Planta e corte de estudo para o Pavilhão Serpentine - 2006 
da Galeria Serpentine com suas fotografias ${ }^{171}$, produziu uma obra para ocupar a frisa da base do inflável. Levando em consideração na montagem de sua exposição as características arquitetônicas da galeria principal - um ambiente quadrado com um forro em forma de cúpula -, o artista reveste as paredes com a aplicação de texturas, no intuito de subverter a neutralidade do "cubo branco" e aludir ao papel-de-parede como elemento tradicional das residências inglesas (figura 72). Assim, o artista cofere à galeria e com sua reduzida escala, uma ambiência quase doméstica. Um dos padrões utilizados nos revestimentos internos é então ampliado e exportado para a frisa na base do inflável (figura 73), estabelecendo um espelhamento entre os dois salões, suas proporções, suas coberturas e conecta o trabalho de Demand, fundamentado na oposição entre a permanência das estruturas e a impermanência do artifício, com o próprio pavilhão.

Tanto o recinto que abriga o público quanto o balão ovóide foram revestidos por materiais translúcidos que proporcionavam uma sensação de leveza e transparência ao ambiente, que era inundado por uma luz difusa durante o dia, e, durante a noite, transformava o pavilhão em uma grande lanterna ou possível suporte para intervenções, projeções e outras apropriações. Além disso, o movimento do inflável estabelecia uma relação de escala - preocupação constante no trabalho de Koolhaas ${ }^{172}$ - com o pequeno bloco principal da Serpentine Gallery, e com o enorme Hyde Park e sua escala metropolitana.

Koolhaas e Balmond, que já haviam trabalhado em colaboração

171 As fotografias de Thomas Demand retratam o lugar comum, a vida cotidiana e seus ambientes compostos por objetos banais. Quando observadas atentamente revelam o artifício empregado pelo artista que reproduz tais ambientes em maquetes de papelão para posteriormente fotografá-los. Na exposição da galeria Serpentine, Demand exibiu pela primeira vez "Grotto", a fotografia de um grande modelo que reprodução em papel cartão uma gruta em Maiorca. A complexidade desta obra foi comparada à "Merzbau" de Kurt Schwitters, tratada no capítulo 2, desta dissertação, p. 55-56.

172 Rafael Moneo ressalta que Koolhaas se preocupa com a contemporaneidade de suas obras inseridas num contexto global definido pela cultura de massa, não relacionado ou determinado por um lugar. A implantação de seus projetos busca sempre encontrar a escala adequada relacionada ao uso que as pessoas - indivíduos ou massa - farão do edifício. Assim coloca-se como um arquiteto que se oferece ao mercado de forma instrumental e a serviço das necessidades da sociedade contemporânea. In: MONEO.Op. cit., p. 290. 

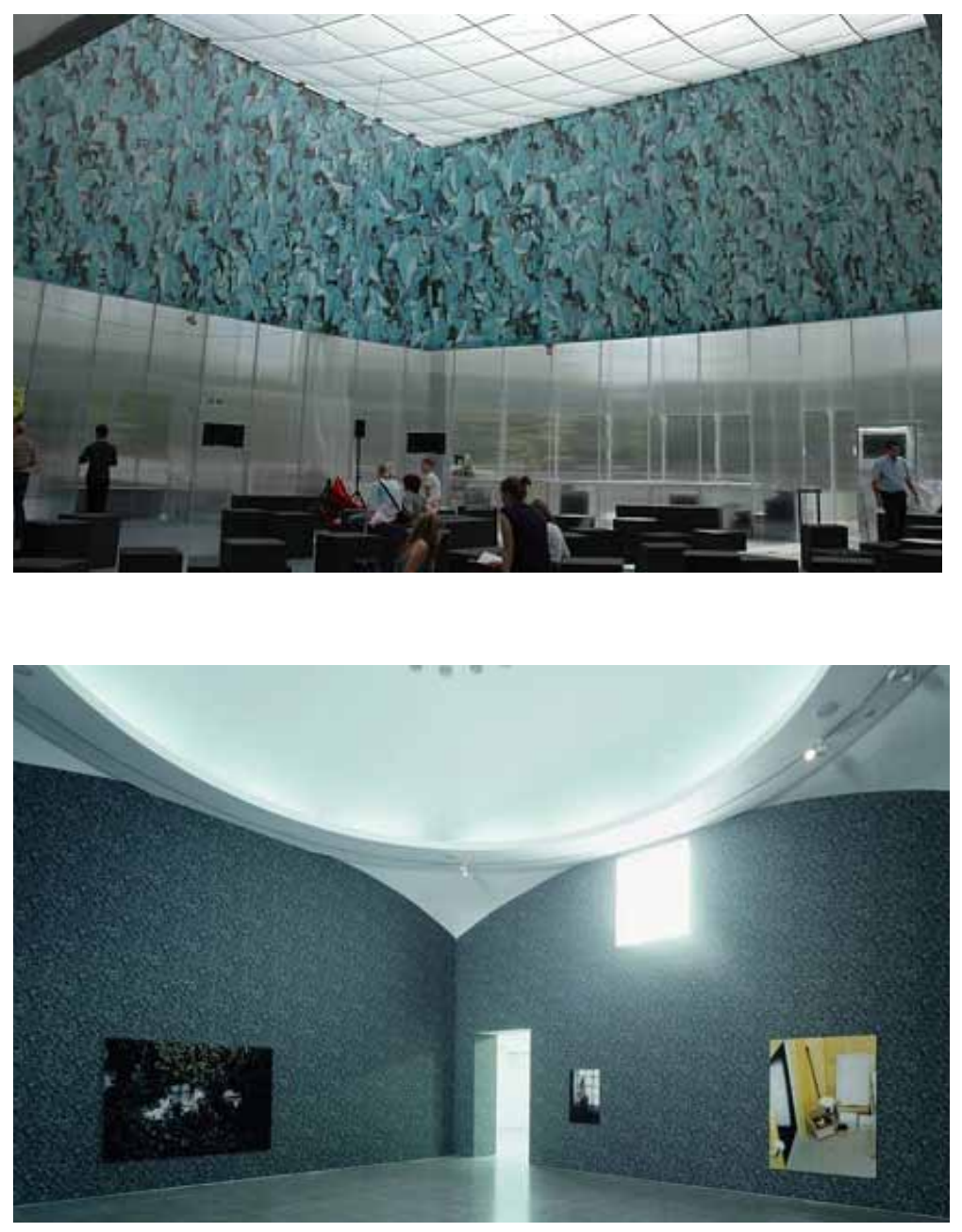

\section{figura 72}

Rem Koolhaas e Cecil Balmod. Pavilhão Serpentine - 2006

\section{figura 73}

Thomas Demand. Vista interna da Exposição. - 2006.

(Serpentine Gallery, Londres) 
em diversos projetos antes do pavilhão Serpentine ${ }^{173}$, articulam estas duas escalas distintas como uma estrutura que é indissociável da arquitetura e de seu resultado formal. O grande balão inflado, sujeito a deformações pelos seus deslocamentos, não repete a tradicional operação onde o esqueleto estrutural é posteriormente recoberto por uma casca que lhe confere a forma e, portanto, responde a uma das grandes inquietações do arquiteto - o que nem sempre ocorre em sua obra construída -: o desejo de descolar-se da sedução da forma. O balão inflável é decorrência de sua própria estrutura, de seus materiais e da ação da gravidade. Esta indeterminação da forma vem atrelada às intenções e aos conceitos aplicados ao projeto e pode ser acompanhada pelos diversos croquis que ensaiam as soluções da cobertura, onde em cada desenho o balão assume um novo contorno. Esta característica é comentada por Balmond como uma estimulante constante na sua parceria com Koolhaas, onde o arquiteto demonstra uma "ausência de preciosismo, um desinteresse nos "poderes especiais" da arquitetura. Fazemos o que fazemos, o que acontecer, aconteceu." 174

Outra especulação em sintonia com as pesquisas anteriores do arquiteto é sua relação com o programa. A grande forma que se destaca na paisagem não é um contêiner, não recebe programa algum, nem mesmo a já reduzida demanda de abrigar um café e um salão para trezentas pessoas. Se a arquitetura elimina a liberdade, como expressa o arquiteto com contundência na sua frase: “onde não há nada tudo é possível: onde há arquitetura, nada mais é possível" ${ }^{175}$, a cobertura com seu grande volume, que dá forma ao pavilhão é apenas um grande vazio preenchido por ar, independente do programa e pronto a assumir o papel de uma "tábula-rasa" 176 , um receptáculo aberto para comunicar e ser utilizado por artistas, podendo absorver diversos significados e,

173 Rem Koolhaas a frente do OMA e Cecil Balmond do escritório de engenharia e tecnologia Arup, colaboraram em diversos projetos emblemáticos nas últimas décadas, como a Casa de Bordeaux (1998), o Kunsthal de Roterdam (1987-92), a Casa da Música do Porto(2005) e o edifício da CCTV na China(2002).

174 Cecil Balmond em entrevista a Julia Peyton-Jones presente no catálogo da exposição: Serpentine Gallery Pavlion 2006. PEYTON-JONES/OBRIST. Op. cit. p.46.

175 Rafael Moneo cita esta frase de Koolhaas publicada no livro "S,M,L,XL" escrito pelo arquitetor e por Bruce Mau. MONEO. Op. cit., p. 289.

176 É assim que Koolhaas se refere ao pavilhão e à neutralidade de seus materiais manipulados como possibilidade de inverter uma relação tradicionalmente autônoma do pavilhão de jardim para uma relação simbiótica e receptiva a intervenções. OBRIST / PEYTON-JONES. Op. cit. p.46. 
assim, diluir a noção de autoria e identidade do autor. Neste sentido, Koolhaas pondera, em entrevista concedida a Julian Peyton-Jones ${ }^{177}$, que o potencial discursivo do pavilhão foi o que o mais o estimulou a aceitar o convite.

O pavilhão de Koolhaas consegue explicitar grande parte de suas reflexões críticas e de fato funcionar também num âmbito discursivo, decantando diversas camadas que remetem a seus potentes escritos pelos quais conquistou reconhecimento antes mesmo da consolidação de sua obra construída. Sua adesão à Nova Iorque como a cidade moderna por excelência, capaz de se organizar e se estruturar em torno da congestão e da densidade resultantes do avanço do capitalismo desenfreado e da cultura de massa, é destrinchada no livro “Delirious New York" (1978) ${ }^{178}$, e reflete-se na prática pela sua preferência em utilizar materiais vulgares - típicos da arquitetura espontânea - adotar procedimentos construtivos característicos de uma arquitetura de viés mais comercial, e fazer uso de "referências com uma literalidade aterradora." 179

A primeira imagem que o inflável suscita como referência são os projetos do grupo Archigram, que marcavam forte presença na Architectural Association - AA - nos anos de formação do arquiteto.

Impossível não associar a bolha flutuante, móvel e neutra do pavilhão aos out-doors pop do projeto experimental Instant City (1968 - imagem 74). A cidade efêmera era pensada como um evento que surgiria nos locais mais remotos, como pequenas cidades de interior, levando consigo toda uma parafernália tecnológica de informação, entretenimento e cultura de massa que depois desapareceria com o deslocamento da cidade pelo ar, atirantada a infláveis.

A maratona de entrevistas que o arquiteto e Obrist realizaram no pavilhão - um evento de grande intensidade e diversidade de informação que concentrou diversas personalidades ligadas às artes, filosofia, política e história da cidade na tentativa de se revelar camadas invisíveis da cultura urbana londrina -, também parece encontrar suas raízes nas especulações da Instant City.

177 OBRIST/ PEYTON-JONES. Op. cit. p.42.

178 KOOLHAAS, Rem. Nova Iorque Delirante. São Paulo, Cosac Naify, 2008.

179 MONEO. Op. cit., p. 289. 


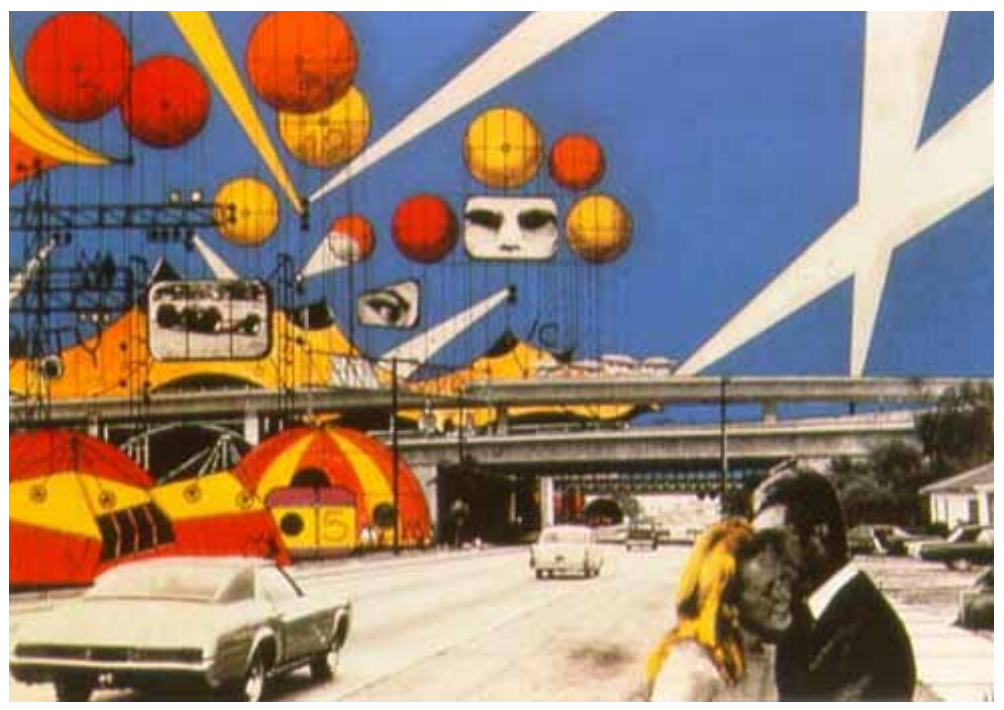

figura 74

Archigram. Instant City - 1968 
Koolhaas nega a ligação entre seu pavilhão e as especulações do grupo Archigram, embora reconheça que a proximidade com estes projetos nos seus anos de formação o tenha estimulado a se posicionar criticamente. Ao reforçar este distanciamento, toma para si como contraponto e referência essencial o "Fire Pavilion", e as "arquiteturas de ar" (figura 75) que o artista francês Yves Klein, em colaboração com os arquitetos Claude Parrent e o engenheiro Werner Ruhnau, criaram na virada dos anos 50 para os anos 60 . Estes projetos trabalhavam elementos naturais associando-os à arquitetura em instalações que alternavam jatos de água, intercalados a colunas com um mesmo volume de jatos fogo, de forma que entre eles o ar pudesse expressar um intervalo sensorial impregnado de significados cosmológicos.

Koolhaas desvela em seus projetos, assim como neste pavilhão, que suas referências teóricas e procedimentos conceituais convergem em sua prática arquitetônica no OMA, muitas vezes antecedida e informada pelo seu duplo, o $\mathrm{AMO}^{180}$. Cecil Balmon comprova que a engenharia não é apenas mero aparato técnico ou cálculo complementar submetido ao projeto arquitetônico e, junto da AGU - Advanced Geometry Unit -, um dos cinquenta sub-grupos da Arup ${ }^{181}$, investiga novas formas de espaço e estética catalisadas pela geometria conectada a diversas instituições acadêmicas em todo o mundo.

O pavilhão Serpentine de 2006 resulta da parceria entre dois profissionais que, à frente de estúdios multidisciplinares, buscam outros critérios e bases para desenvolver uma arquitetura inventiva. O resultado aproxima-se, pelos métodos empregados em seus estúdios - que se baseiam numa abrangência de pesquisas e interesses conceituais -, a boa parte da produção artística contemporânea.

180 No final dos anos 90, o OMA foi exposto pela primeira vez à mudança que tomou conta do mundo da mídia, e com ele, a importância crescente do domínio virtual. Isso levou Rem Koolhaas e o Office for Metropolitan Architecture - OMA - a criar uma nova empresa, a AMO - Architecture Media Organization -, exclusivamente dedicada à investigação e desempenho neste universo. AMO atua em áreas além dos limites tradicionais da arquitetura, incluindo mídia, política, sociologia, energia renovável, tecnologia, moda, curadoria, edição e design gráfico. A AMO coordenada por Rem Koolhaas e Reinier de Graaf, muitas vezes trabalha em paralelo com os clientes do OMA para fertilizar a arquitetura com inteligência a partir deste conjunto de disciplinas. Texto de apresentação do escritório disponível no site: < http://oma.eu/oma> consultado em 19/01/2012.

181 Escritório de cálculo, fundado em 1946, que contribuiu para a execução de projetos como a Ópera de Sidnei e o Centro George Pompidou. 


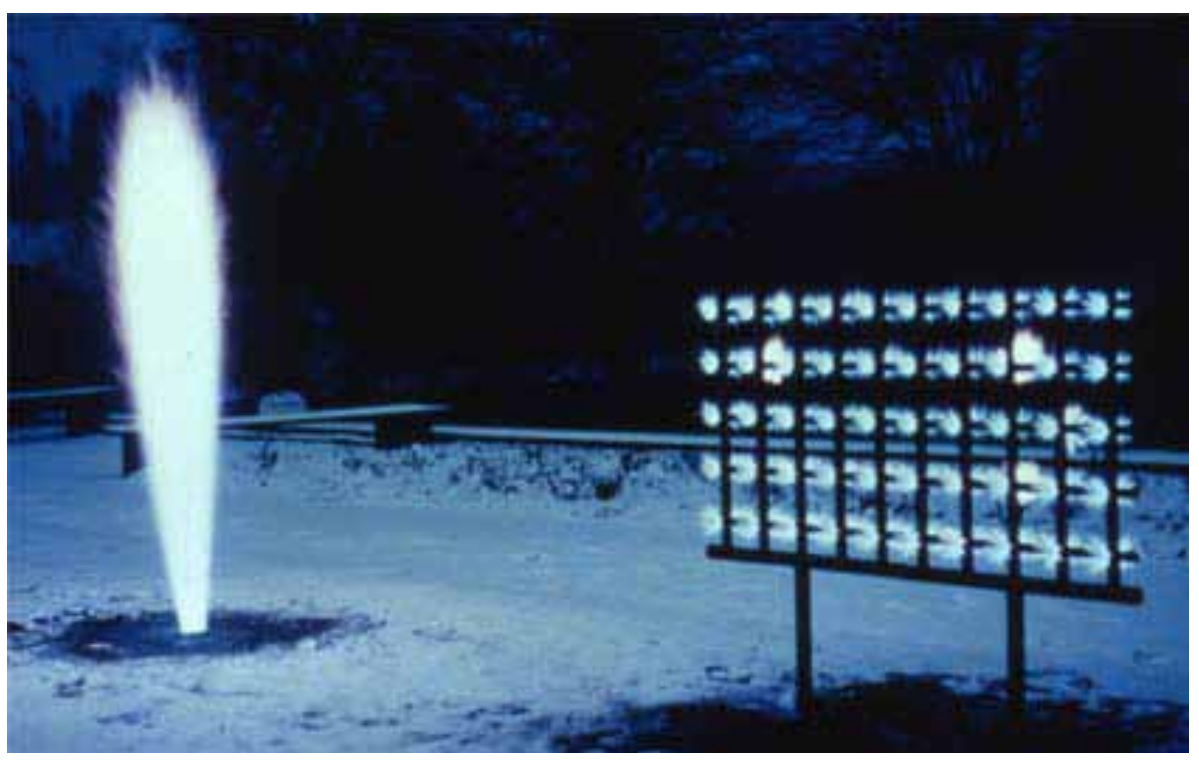

figura 75

Yves Klein. Monocromo e fogo, Air Architecture - 1961

(Museu Haus Lange, Krefeld, Alemanha) 


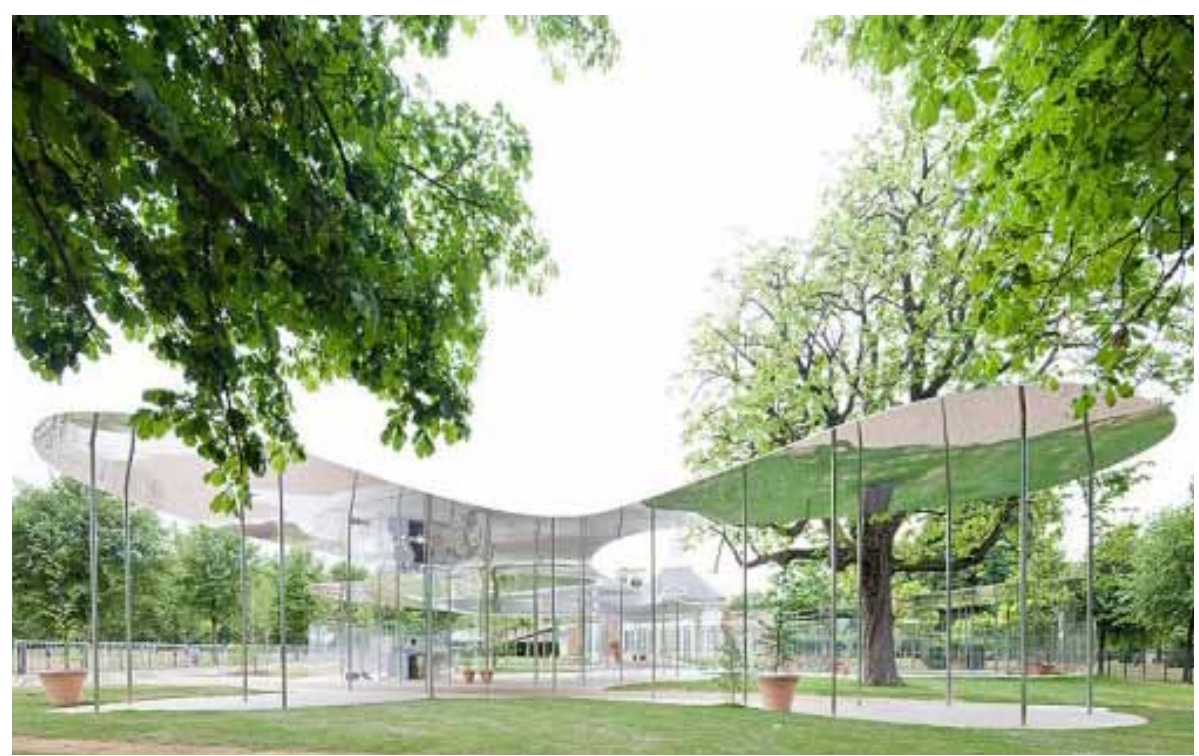

\section{figura 76}

SANAA. Pavilhão Serpentine - 2009

(Serpentine Gallery, Londres) 


\subsection{SANAA - 2009}

Kazuyo Sejima, arquiteta japonesa, imaginou um escritório que pudesse funcionar como músicos de jazz improvisando, cada um tocando seu instrumento e diferentes melodias gerando uma única harmonia ${ }^{182}$. Para isso convidou toda sua equipe a se associar ao seu escritório, mas somente Ryue Nishizawa aceitou, formando assim o SANAA, que conquistou o prêmio Pritzker, em 2010.

Os dois arquitetos mantém uma prática individual além do seu trabalho em conjunto no SANAA, e ambos refletem uma produção contemporânea fundamentada na noção de diagrama. Toyo Ito - com quem Sejima inicialmente trabalhou - foi quem primeiro retomou este termo para descrever o trabalho da arquiteta em $1996^{183}$. Por mais que o diagrama derive de uma premissa programática, sua tradução para o espaço nas obras do SANAA resulta em formas claras, que priorizam grandes coberturas horizontais - por vezes desdobradas em uma acomodação de níveis de forma fluída - que diluem espaço interno e externo por meio de finas camadas de paredes e intenso uso de superfícies de vidro, acomodando o programa através de um exaustivo método de recombinação de partes, como uma estrutura seriada de Sol Lewit. Este método é calcado no processo e não num resultado formal esperado, o que segundo Mohsen Mostafavi trata-se de "uma reticência sistemática em direção ao imediatismo da visualidade gestual e icônica” ${ }^{184}$.

De fato, a arquitetura da dupla tende a uma leveza e transparência até a desintegração, e no projeto para o pavilhão Serpentine(figura 76), livres da incumbência de resolver um programa, partem para uma radicalização de sua pesquisa no sentido de criar uma estrutura que se

182 Entrevista concedida a Mohsen Mostafavi em 2010 publicada na revista El Croquis $\mathrm{n}^{\circ} 155$, p.6-16.

183 "It is a systematic reticence toward the immediacy of gestual and iconic visuality." MOHSEN. 2010, p. 245.

184 Para um aprofundamento da discussão em torno da arquitetura diagramática ver: Diagrams of Diagams. Architectural Abstractions and Model Representation. VIDLER, 2000, p. 1. 
dissolve no parque, de tão difícil sua apreensão ao olhar. Uma marquise de $2.6 \mathrm{~cm}$ de espessura, em aço inoxidável, é apoiada sobre pilares de $5 \mathrm{~cm}$ de diâmetro distribuídos de forma aleatória pelo plano amebóide.

A cobertura é entendida como mais uma copa de árvore, e os pilares como seus troncos. O pavilhão mimetiza a paisagem do parque em uma continuidade que manifesta sua maior qualidade, a liberdade, expressa nos movimentos e atividades do público. Assim, a cobertura que nos primeiros estudos, ainda aparece como uma aglutinação de diversas copas de árvores ${ }^{185}$ (figura 77), chega em alguns estudos a ganhar uma extensão muito maior que a do projeto realizado ${ }^{186}$, expandindo-se em diversas direções de forma a integrar-se ao parque e diluir-se na paisagem que absorve em seus reflexos. A superfície de alumínio polido, na sua face inferior, reflete imagens deformadas do piso e do público sob ela, na face superior reflete o céu e as árvores. Sem se fechar, o pavilhão possibilitou o acesso do público por diversos pontos, e estabeleceu, na sua curta existência, um acolhimento a atividades irrestritas como reflexo natural do uso do parque.

Dois recintos foram criados pela inserção de uma estrutura de acrílico transparente que não chegam a tocar a cobertura, delimitando as áreas para concertos e conferências. O pé direito varia e cria espaços com características diferentes, desde um espaço alto onde a cobertura dobra-se em direção ao céu e propõe-se a receber uma multidão, até um mais acolhedor e íntimo, rente ao chão que convida a uma outra postura, mais recolhida.

A sinuosidade do desenho da cobertura, ao contrário de sua nítida referência e reverência ${ }^{187}$ à marquise do Ibirapuera, em São Paulo, - que conjuga reta e curva manifestando que, por trás da liberdade da curva, existe um gesto calculado - no pavilhão do SANAA parecem totalmente soltas, ou mesmo aleatórias, e nos croquis de apresentação

185 Este raciocínio revela uma lógica estrutural implícita ao partido. Para ser construída, a cobertura foi dividida em oito setores, cada um subdividido em dez ou vinte partes fixadas in loco até configurarem o todo.

186 A cobertura teve que ser reduzida, segundo Sejima, dadas algumas limitações do programa, dentre elas, o fato da estrutura ser revendida. In: JODIDIO. Op. cit. p.06.

187 Os arquitetos são admiradores confessos da arquitetura de Niemeyer e por ocasião da inauguração de uma exposição com seu trabalho, em agosto de 2008, no Instituto Tomie Ohtake em São Paulo, visitaram algumas de suas obras, dentre elas a marquise do Ibirapuera. 

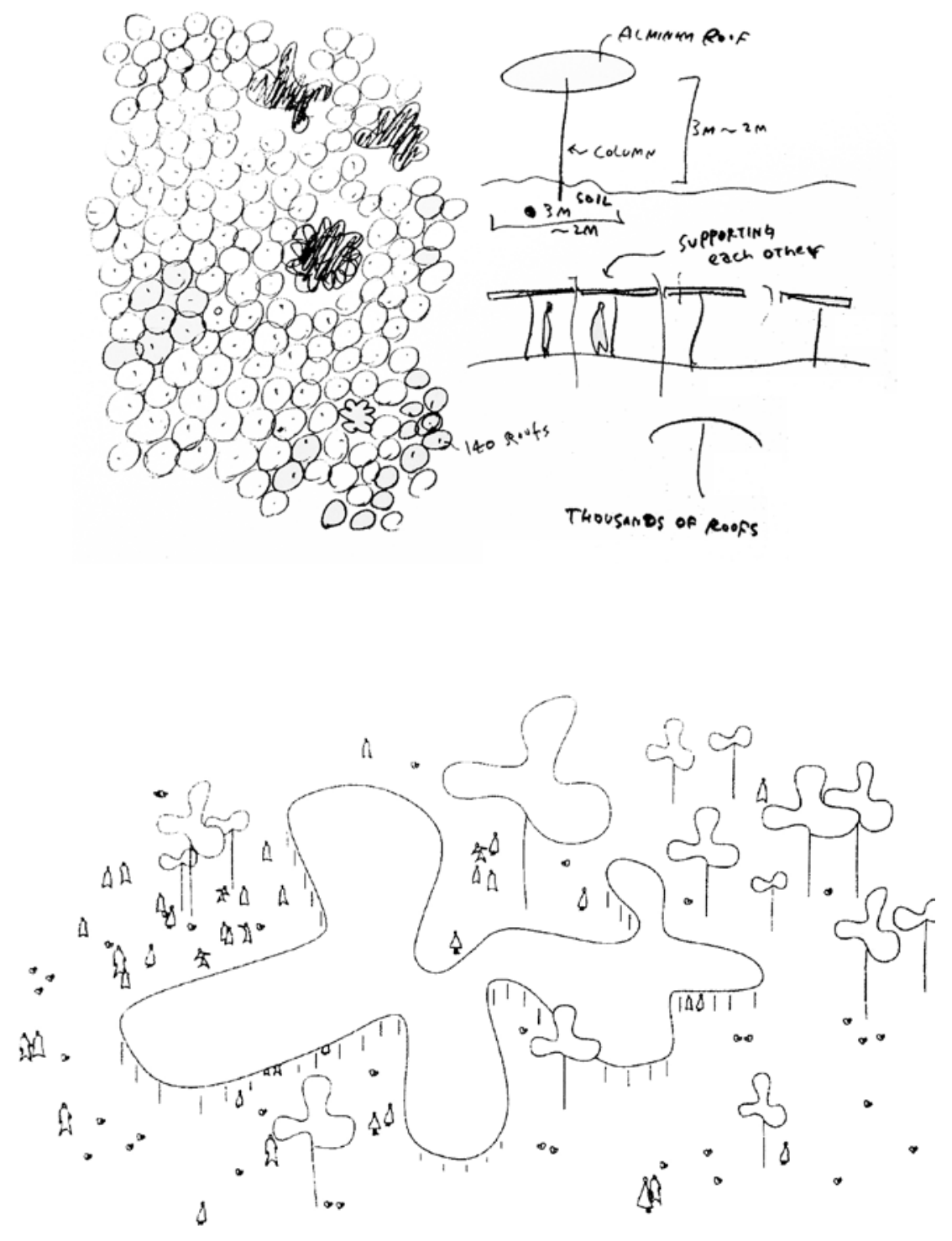

figuras 77 e 78

SANAA. Croquis para o Pavilhão Serpentine - 2009 
do projeto surgem com o mesmo peso gráfico da representação das árvores, como se fossem um mesmo ícone reproduzido (figura 78). O desenvolvimento desta primeira imagem segue como um processo de tentativa e erro e gera diversos modelos para que, depois de esgotadas as possibilidades e estudadas a relação de sua implantação no parque - as árvores e a construção existentes - finalmente seja selecionado o projeto que melhor se encaixa no local (figura 79).

Assim como na marquise de Niemeyer, o corte aqui não possui qualquer expressividade, e toda a força do projeto está na superfície plana, no desenho do piso e da cobertura, em sua planta e vista superior. Mas as características que conectam estes projetos não são meramente formais. Este pavilhão, entre todos os outros já executados pelo programa, é o que mais possibilita uma reflexão sobre os usos ao colocarse como uma obra aberta a diversas atividades, como também ocorre na marquise do parque Ibirapuera, um dos espaços mais democráticos e convidativos ao uso na cidade de São Paulo.

A diluição das imagens na cobertura flutuante coloca aos usuários do pavilhão o desafio de se orientar em meio a distorções e reflexões, num processo de sensibilização para "suas relações com as coisas e os espaços ao seu redor"188. Céu e chão convergem na cobertura em suspensão, que então desaparece, não por sua transparência literal, mas por efeitos espaciais desconcertantes.

O pavilhão projetado pelo SANAA resume-se, portanto, ao conceito de "atmosfera" aplicado por Sejima à sua curadoria da Bienal de Veneza em 2010. Nishizawa explica que este conceito, constantemente utilizado pela dupla, tem dois sentidos. Um, antes da construção do edifício, como uma condição que é negociada nos processos conceituais que norteiam o projeto, e criam um distanciamento crítico necessário ao desenvolvimento do trabalho o que possibilita desdobramentos formais indeterminados. Outro, que mantém o projeto aberto como possibilidade de assimilação de seus espaços pelos usuários, descolado das intenções de possível controle de seu autor, como um experimento científico que lança sua hipótese baseado na total incerteza de seu resultado.

188 Esta é a descrição de Eve Blau para o projeto do Museu de Arte contemporânea do Século 21(1999-2004), em Kanazawa, Japão, projetado do SANAA. Tais características aplicam-se com exatidão ao pavilhão Serpentine e a outras obras da dupla. BLAU, 2010, p.1. 

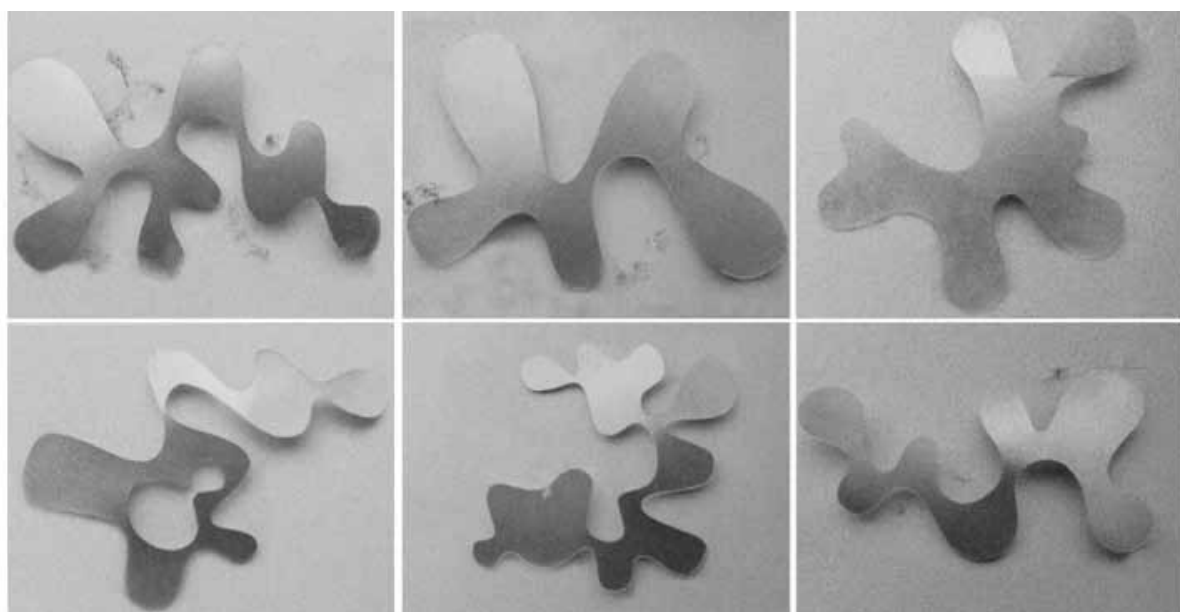

figuras 79

SANAA. Maquetes de estudo para o Pavilhão Serpentine - 2009 


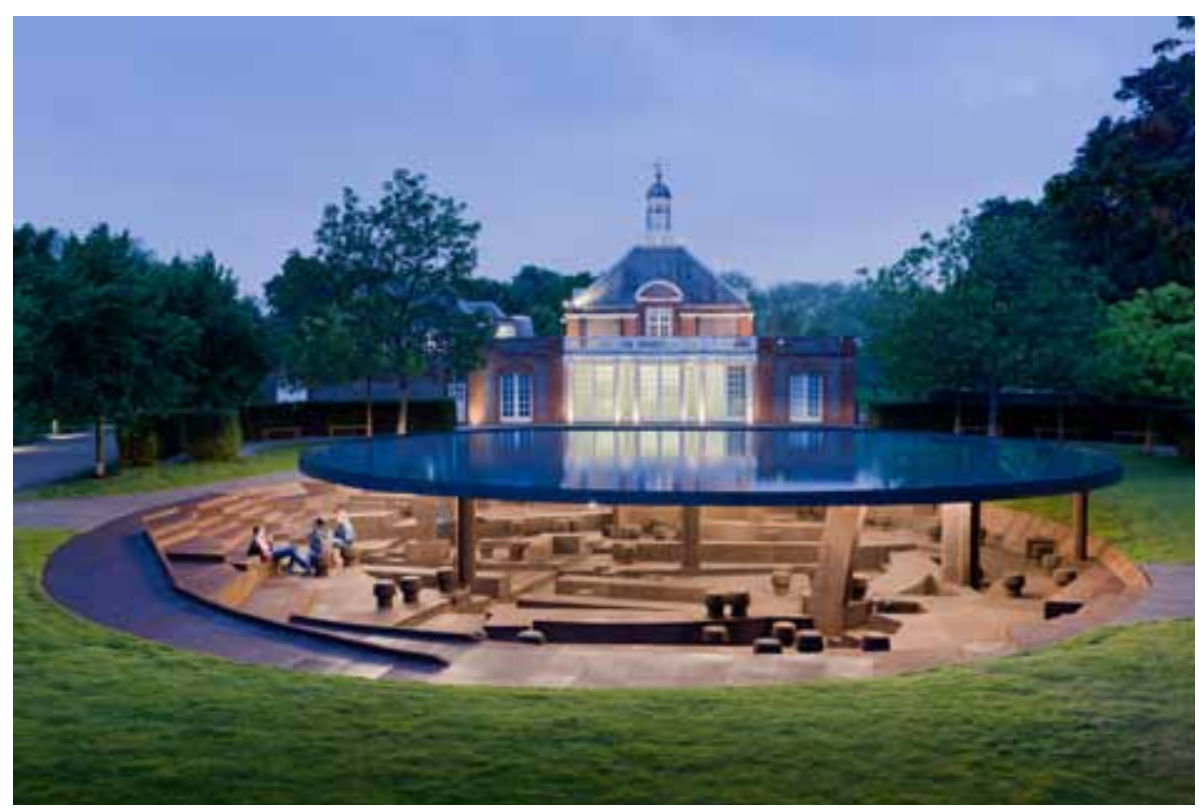

\section{figura 80}

Herzog e De Meuron e Ai Weiwei. Pavilhão Serpentine - 2012 (Serpentine Gallery, Londres) 


\subsection{Herzog \& De Meuron e Ai Wei Wei - 2012}

Jacques Herzog e Pierre de Meuron, arquitetos suíços vencedores do prêmio Pritzker em 2001, estão à frente do escritório Herzog e De Meuron desde 1978, e são reconhecidos por terem projetado nas últimas duas décadas algumas obras de escala urbana monumental, como grandes equipamentos públicos, a exemplo do estádio olímpico de Pequim para as Olimpíadas da China (20042008) em parceria com o artista e arquiteto chinês Ai Weiwei ${ }^{189}$.

A parceria já havia se consolidado na colaboração da dupla suíça no desenvolvimento do Jinhua Park (2002-2006), um parque linear contendo dezesseis pavilhões com temas diversos estipulados por Weiwei - alguns destinados a receberem restaurante e exposições, outros sem qualquer uso ou finalidade a não ser o de proporcionar pontos de vista e conduzir o percurso, de forma a proporcionar experiências espaciais ao longo do parque que homenageia o poeta Ai Qing, pai do artista/arquiteto.Herzog \& De Meuron contribuíram na seleção de escritórios internacionais e desenvolveram a "Estrutura II”(2004-2006), espaço dedicado a leitura e construído em concreto pigmentado unindo ornamento e estrutura a partir da extrusão de hexágonos de um prisma retangular, resultando em diversas possibilidades de acomodação do corpo em frestas que enquadram vistas do parque (figura 81).

Para o projeto do pavilhão Serpentine (figura 80), a interação da equipe se deu à distância uma vez Weiwei está impedido de deixar Pequim em função de suas constates críticas ao regime político

189 A conjunção desta equipe explica a subversão das normas da Serpentine Gallery, que sempre convida arquitetos que nunca tenham projetado no Reino Unido. Herzog e De Meuron são os autores de importantes obras edificadas em Londres: a Tate Modern, sua ampliação em construção e também do Laban Dance Centre. Outra característica é que Ai Weiwei atua como arquiteto e não como artista. Weiwei fundou, em 2003, um escritório de arquitetura, o FAKE Design, que já realizou mais de sessenta projetos, além de receber diversos arquitetos estrangeiros na China. 


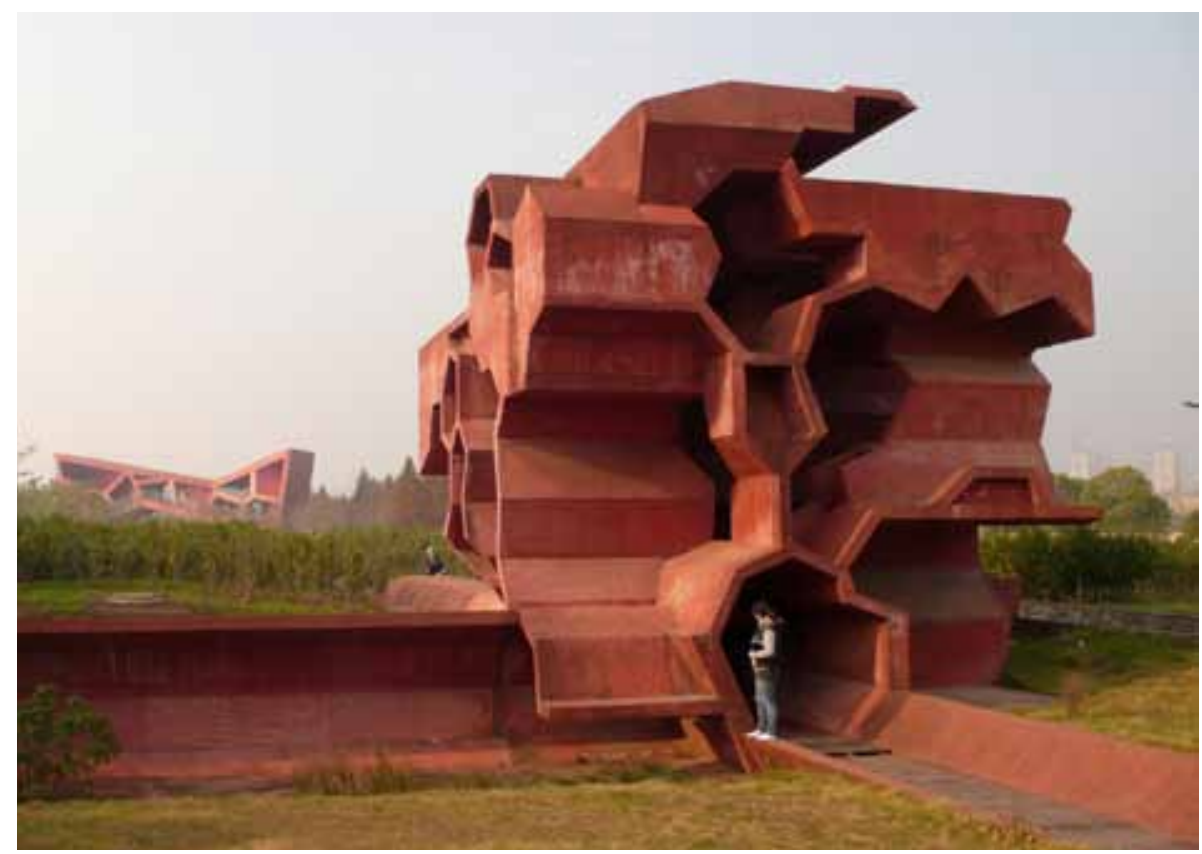

figura 81

Herzog \& De Meuron. Estrutura II - 2007/2006

(Jinhua Park, Zhejiang, China) 
totalitarista chinês, em ações que embaralham vida pessoal, obra e produção artística.

O projeto parte de uma intenção que desafia de diversas maneiras o próprio programa Serpentine, e que segundo Silvia Lavin no texto "Vanishing Point", publicado em Outubro de 2012, na revista Artforum, pode apontar para a própria exaustão da recente afluência dos pavilhões na cena cultural contemporânea. Partindo desta perspectiva, mas com uma interpretação diversa desta, que explora a ambiguidade no termo "ponto de fuga", é possível entender que a desmaterialização do pavilhão não reflete um esgotamento, mas é consequência da aproximação de campos tratados neste trabalho.

Ao explicar o projeto, Jaques Herzog comenta que o desejo de não criar mais um objeto, como exige por princípio toda encomenda arquitetônica, direcionou a equipe para estabelecer uma associação do pavilhão à paisagem. Como desenvolvimento natural deste raciocínio, os arquitetos decidem escavar a terra, gesto que revela um desejo de redescoberta das origens e do manuseio de uma matéria primordial. Aqui, um primeiro paralelo com a landart é inevitável, não somente pelo engajamento com uma obra que resultasse em transformação da paisagem ou mesmo da sua materialidade sensorial e telúrica, mas principalmente por se tratar de uma obra site-specific nos seus diversos desdobramentos.

Herzog \& de Meuron são reconhecidos como um escritório que fundamentou sua prática projetual na assimilação de procedimentos e conceitos provenientes do universo artístico como poucos outros no cenário contemporâneo, e citam como referência duas figuras díspares. Por um lado Donald Judd, pela contenção formal manifesta em geometrias puras que expressam a potência dos materiais e das superfícies planas que resultam na importância dada à pele do edifício que conforma o volume. Por outro lado, Beuys, a quem convidaram em 1978 a colaborar com o bloco de Carnaval que participavam na Basiléia. Bueys não só aceita o convite como concebe indumentárias de feltro - que posteriormente foram 
incorporadas na instalação "Feurestätte 2" -, fornece réplicas de sua instalação "Feurestätte 1" para servir de alegoria, e ainda participa do desfile. Este mito original do escritório Herzog e de Meuron explica muito da habilidade com que a dupla utiliza a matéria num sentido multissensorial e simbólico. A aproximação improvável de Judd e Buyes reflete-se, segundo Joseph Rykwert, no catálogo de apresentação do pavilhão Serpentine 2012, em "uma consciência aguda da qualidade do material e numa valorização igualmente afiada do projeto, tanto como uma invenção geométrica como uma intriga conceitual." ${ }^{190}$

O trio de arquitetos transforma a escavação do pavilhão em um processo exploratório de descoberta, como um sítio arqueológico que revela aquilo que não é visível. "Não é um chão inocente, temos muitas coisas e muitos vestígios do passado" ${ }^{191}$, afirma Herzog. Resquícios surgem sob a terra e, assim, se reconstrói a própria história do programa ao se desvelar as fundações dos onze pavilhões anteriores.

Inicialmente, a desmaterialização seria total e nenhum volume ou cobertura seria construído (figura 82), mas cientes de que o limite de profundidade seria de um metro e meio devido ao alto nível do lençol freático, esta intenção foi abandonada e a água foi incorporada ao projeto aflorando de quando em quando na cota mais profunda, mantida sem revestimento permanecendo em terra batida.

Uma fina camada de água é também recuperada na cobertura como espelho d'água capaz de captar, armazenar e extravazar a água das chuvas. O espelho d'água é na verdade a cobertura do pavilhão, erguendo-se levemente do solo no nível do parque de forma a refletir e incorporar o céu e as árvores do parque, mimetizando todos os elementos em uma síntese do conceito de paisagem capaz desintegrar a arquitetura.

190 RYKWERT, Joseph. Excavating the Future. In: Herzog \& the Meuron + Ai Weiwei Serpentine Gallery Pavilion 2012. p.44

191 Depoimento de Herzog em vídeo está disponível no site: <http://www. serpentinegallery.org/2012/02/serpentine_gallery_pavilion_2012.html> 

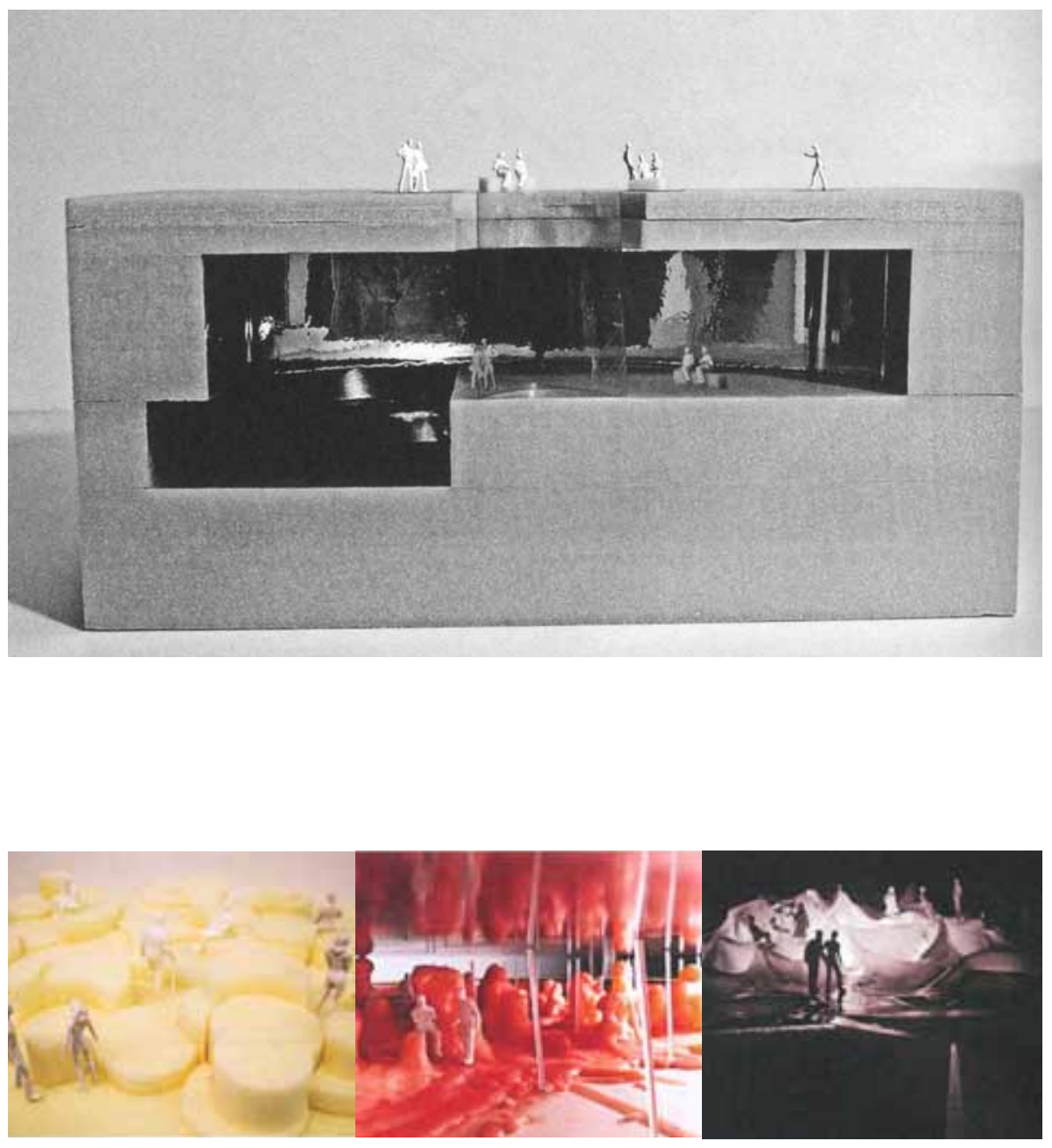

figuras 82 e 83

Herzog \& De Meuron e Ai Weiwei.

Maquetes de Estudo par o Pavilhão Serpentine - 2012 
De fato, o fino disco ${ }^{192}$ de metal circular da cobertura - com uma pequena fatia extraída na extremidade de forma a estabelecer uma reta paralela ao edifício principal - tem baixíssimo impacto visual na paisagem do parque, e só é percebido quando o visitante está muito próximo, assim como a escavação, também em forma circular deslocada do centro de forma a permitir que o público ganhe altura antes cruzar a viga de borda da cobertura. A escolha desta geometria pura é justificada como uma busca por independência de qualquer vocabulário formal ou expressivo, mas que, ainda assim, possibilitasse uma fácil apreensão da forma, preservando um sentido de horizontalidade - busca constante mesmo nas obras de maior escala da dupla suíça ${ }^{193 .}$

A forma de geometria pura circular é o suporte para que a materialidade se revele como forma, e no caso da escavação do solo é á que a complexidade da proposta se revela como parte da intriga conceitual mencionada por Reikwert. Diversas maquetes foram produzidas para que os arquitetos estudassem topografias, ensaiando abstrações em borracha e silicone ou possíveis estalagmites transparentes que remetessem a nuvens (figura 83). No entanto, para recuperar a memória das onze edições anteriores, além de deixar expostas as fundações transformadas em doze pilares de sustentação - o décimo segundo para representar a edição em questão - recuperou-se cada um dos onze projetos que tiveram suas plantas sobrepostas num jogo de apagamentos e extrusões que resultaram na topografia impressa no solo(figuras 84 e 85). Este desenho transforma-se em escadas, percursos em diferentes níveis, assentos ou mesas e proporciona diversas situações para o corpo de acordo com os diversos usos propostos: café194, auditório, exibição de filmes

192 A referência a um CD como forma plana, fina e com um furo central para a captação de água é demonstrada em uma foto em que Ai Weiwei se comunica com Jaques Herzog e Pierre de Meuron através de uma vídeo-conferência.

193 "Herzog \& De Meuron frenquently integrated into their designs the horizontal parameters of the site on wich they are working." Ou "Herzog e de Meuron frequentemente integram ao seu desenho, parâmetros horizontais do sítio onde estão trabalhando. In: CHEVRIER. 2006, p. 11.

194 Ao contrario de outras edições o café foi pensado como quiosque móvel autônomo, estacionado ao lado do pavilhão que servia como espaço coberto para a realização de lanches. 

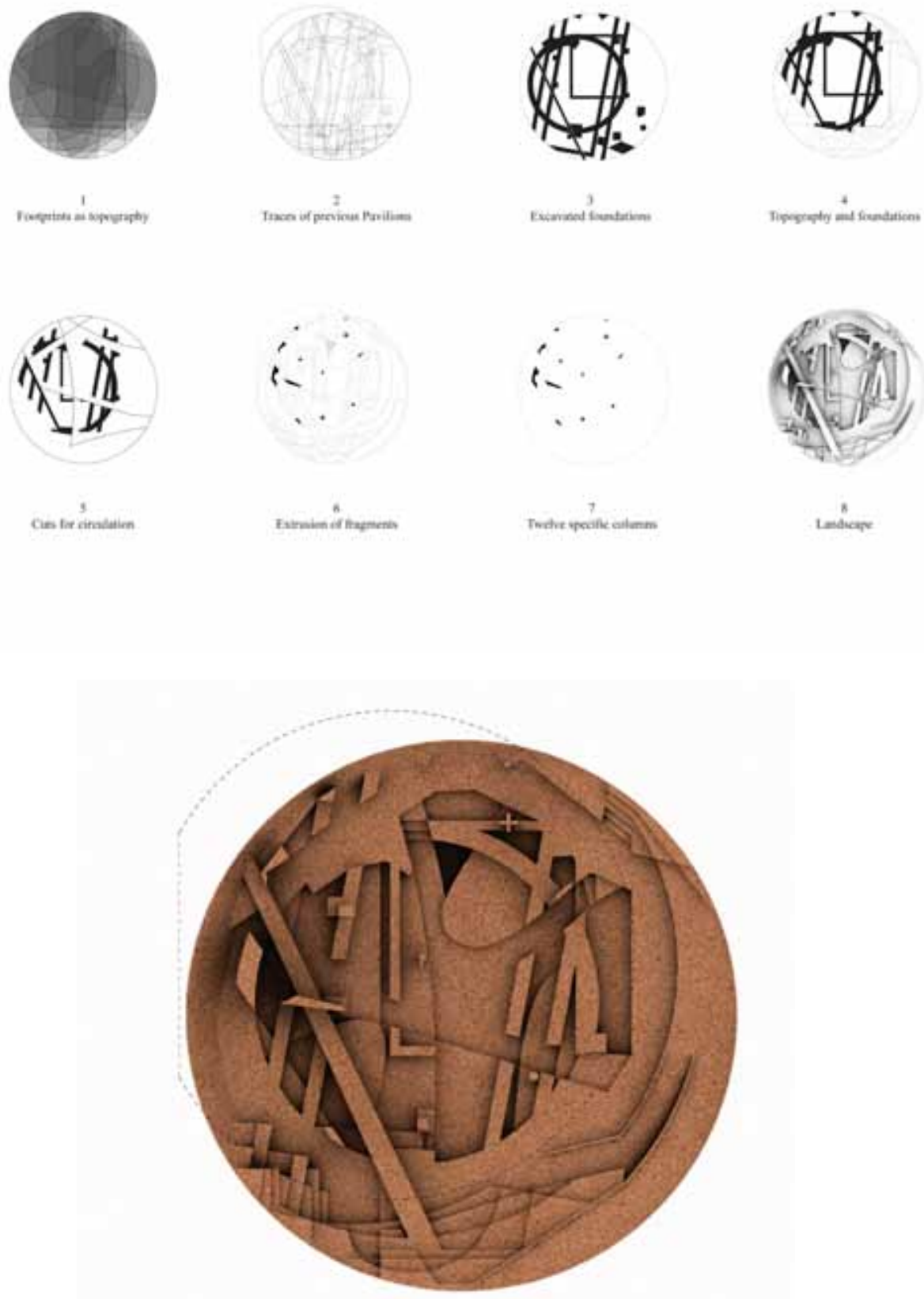

figuras 84 e 85

Herzog \& De Meuron e Ai Weiwei.

Desenhos processuais para o Pavilhão Serpentine - 2012

Modelo em baixo relevo de cortiça com a topografia do Pavilhão Serpentine - 2012 
ou evento. Sentir-se protegido e totalmente integrado ao parque. Possibilitar descobertas para o público.

A escolha da cortiça como material que reveste o chão e as colunas é, assim como no projeto das adegas Dominus, na Califórnia, um veículo para expressão da arquitetura através dos materiais ${ }^{195}$. O uso que Herzog e de Meuron fazem dos muros gabiões de rocha neste projeto de 1995 é transformador. Estes elementos construtivos, associados a contensões de terra, de forma opaca e pesada adquirem leveza ao serem utilizados como paredes vazadas pela luz e conquistam grande expressão plástica neste projeto. $\mathrm{O}$ mesmo ocorre com a cortiça utilizada no pavilhão, um material natural, pouco nobre, produzido ainda de forma bastante artesanal ${ }^{196}$, que possui características sensoriais agradáveis - tato suave, quente, com cheiro característico $^{197}$ - e ainda grande qualidade acústica.

Ao revelar a presença de uma ausência, o pavilhão proposto por Herzog e De Meuron e Weiwei provoca diversas revisões no programa Serpentine, tencionando a instituição. Por se tratar de uma obra site-specific, relacionada à história do local e suas camadas discursivas, a proposta anula a possibilidade de reprodução do pavilhão como mercadoria para suporte financeiro do programa. Isso não implica numa total isenção dos métodos de capitalização com a venda posterior da obra, mas apresenta uma alternativa que valoriza os conceitos, itens processuais e não a reprodutibilidade do objeto fetiche arquitetônico, direcionando uma crítica ao estímulo da curadoria na promoção de arquiteturas espetaculares, motivadas por um ineditismo formal que encobrem uma isenção do programa a um aprofundamento de questionamento de outros conteúdos importantes ao debate arquitetônico como a experiência social.

195 MONEO, op. cit. p. 352

196 O material só pôde ser usado devido à pequena escala do pavilhão e sua efemeridade.

197 Jaques Herzog sempre destaca as qualidades sensuais dos materiais, dentre elas o cheiro como aquele que é difuso, sutil, mas, no entanto, invasivo e incontrolável no estímulo à reminiscência. A química dos sentimentos, isto é, a ambivalência de atração-repulsão, encontra o seu equivalente no domínio da sensação física. In: CHEVRIER. Op. cit. p. 13. 
A solução encontrada pela instituição e os arquietos é a confecção de três edições limitadas: gravuras com os desenhos que sintetizam as operações gráficas que originaram o pavilhão, "Landscape"; uma porcelana chinesa produzida artesanalmente em Jingdezhen, China, contendo a reprodução em baixo relevo da topografia executada no Hyde Park; e "Stool" uma réplica, também em porcelana chinesa, de bancos em forma de rolha de cortiça espalhados pelo pavilhão.

Assim, a edição 2012 do programa Serpentine resulta numa anti-arquitetura, aproximando-se mais do que qualquer outra edição de um resultado instalativo, conferindo ao pavilhão sua potência de zona transitória de experimentação. O trio de arquitetos assimila e explicita seus domínios de procedimentos artísticos, que são expressos por meio de uma materialidade menos construtiva e mais conceitual. 



\section{Considerações finais.}

Os pavilhões em sua atual condição de superexposição no cenário cultural contemporâneo dividem opiniões. Por um lado, há quem os ataque por sua suposta ausência de conteúdo e opulência formal. Por outro, há quem os defenda por renovar experimentações e ampliar o acesso a um debate do papel da arquitetura na sociedade contemporânea.

A postura de críticos como Anthony Vidler é otimista ao acreditar que este "campo ampliado arquitetônico" seria capaz de renovar uma dimensão crítica, política e social da arquitetura, mas críticos como $\mathrm{Hal}$ Foster e Silvia Lavin enxergam na proximidade disciplinar com a arte um enfraquecimento de ambos os campos, absorvidos por uma sociedade de espetáculo e capital financeiro que transforma tudo em imagem de consumo.

Diante deste cenário, a condução das análises apresentadas neste trabalho partiu do entendimento de que, mais do que uma seleção de obras que tratassem do estudo do pavilhão como tipo arquitetônico - no sentido de se construir uma historiografia, contando com o levantamento e pesquisa de fontes diversas, focando numa arquitetura que pressupõe a efemeridade -, seria importante delimitar um recorte que priorizasse os programas e instituições onde os pavilhões se inserem como um enclave que possibilita alinhavar argumentos e comparações de maneira a investigar, por diversos pontos de vista, o que representa de fato esta tendência contemporânea de convergência dos campos da arte e da arquitetura.

Nas Instituições selecionadas é possível verificar, primeiramente, que o próprio termo "pavilhão" apresenta uma considerável maleabilidade na sua aplicação. A noção de pavilhão como uma estrutura necessariamente temporária, é negada tanto no Giardino da Bienal de Veneza quanto em 
Inhotim, na medida em que, em ambos, observamos uma proximidade de seu uso com a galeria.

Em Inhotim esta ambivalência surge no próprio discurso da curadoria que substituiu o uso do termo pavilhão em todo seu material de divulgação - até então presente, por exemplo, em vídeos institucionais -, pelo termo galeria. A negação do pavilhão poderia significar um receio, por parte da instituição, de um desviao do interesse da arte para a arquitetura, que, por si só, está presente em meio ao parque como uma coleção de esculturas autônomas. Hall Foster abre o livro "The Art-Architecture Complex" com a constatação de que, hoje, os limites disciplinares são incertos e ambos os campos operam de forma colaborativa e complementar, mas por vezes, oposta e concorrente. ${ }^{198}$

No entanto, as análises apresentadas demonstram que, seja por processos realmente colaborativos, ou por uma hipertrofia da instalação na obra de alguns artistas, o pavilhão em Inhotim oferece desdobramentos potentes, onde arquitetos não necessariamente se restringem ao papel de mediadores da obra artística.

Em Veneza, a separação do evento dedicado exclusivamente à arquitetura se dá justamente por um entendimento de que à arquitetura não caberia somente o papel de proporcionar uma correta apresentação da obra artística. A história da consolidação dos pavilhões do Giardino, trilhada no capítulo 3, contribui para uma revisão, nos mesmos moldes daquela proposta por Penelope Curtis em "Patio and Pavilion, The Place of Sculpute in Modern Architecture", rumo à constatação da tendência de rompimento de uma relação de complementaridade entre escultura ou obra de arte - e arquitetura. Os pavilhões de Veneza, ao longo de sua história, assumem a característica de uma arquitetura autorreferente que nega o cubo branco como neutralidade necessária para as exibições, e configuram uma coleção de edifícios com grande carga simbólica que passa a ativar a interação de obras pensadas especificamente para dialogarem com aquele lugar, culminando com o que foi denominado de meta-arquitetura.

198 FOSTER. 2011,p. VII-XIII. 
Também em Veneza, a partir dos anos 80, com a criação da Bienal de Arquitetura, vemos a exposição de arquitetura consolidar-se como campo crítico e discursivo da arquitetura, onde esta se aproxima da instalação por entender que o espaço de exposição, como exibição do espaço, é em si uma arquitetura. Novas abordagens expositivas reprogramam usos, propõem arquiteturas dentro dos espaços expositivos e expandem-se para a criação de um novo local onde novos pavilhões, agora temporários, passaram a ser construídos.

Alguns exemplos abordados ao longo do trabalho, como o Museu Kröller Müller, onde foram reconstruídos os pavilhões de Sonsbeek, e o Pavilhão de Barcelona, demonstram o desejo de se fixar estas arquiteturas temporárias como monumentos, desconsiderando que sua força, talvez resida justamente na sua efemeridade e no discurso que se desdobra através de seus registros. Segundo Beatriz Colomina, tal procedimento fragiliza estas obras, fortemente atreladas ao seu tempo, e cuja potência está diretamente relacionada ao fato de que, inevitavelmente, irão desaparecer, pois estão situadas entre a representação e a construção.

O pavilhão representa a possibilidade de uma arquitetura apartada dos contingentes utilitários da prestação de serviços, e assim como outros projetos, "uma arquitetura não edificada [que] alimenta, à longo prazo, a disciplina com ideias e abre questões que inspiram, informam e motivam a experimentação prática e a produção" ${ }^{199}$.

Neste sentido, cabe resgatar Manfredo Tafuri e qualificar o que se entende como experimentação. Tafuri creditava à experimentação um necessário papel para o alargamento e a construção de conhecimento através de um processo de desmonte e remonte de suas bases, lançandose no desconhecido até que novos caminhos se solidifiquem. Como a própria história demonstra, os pavilhões nacionais das feiras mundiais cumpriram esta função ao sedimentar o caminho da arquitetura moderna, mas poderia a produção de pavilhões por parte de alguns escritórios como SANAA, Diller Scofidio \& Renfro, OMA e Herzog de Meuron,

199 "the architectural unbuilt feeds the long term of the discipline with the ideas and open questions that inspire, inform and motivate discipline's pratical experimentations and production" IN: STOPPANI. O.p cit. p. 87. 
apresentadas neste trabalho, ser reconhecida como geradora de obras arquitetônicas contemporâneas capazes de questionar limites disciplinares e estabelecer novos parâmetros críticos e produtivos ao se aproximarem das práticas artísticas que, desde os anos 60, vem dando forma a um campo ampliado da escultura, ou estariam mais próximas de uma redução do papel público da arquitetura ao simbólico e emblemático?

Assim, de um ponto de vista da arquitetura, o programa de pavilhões Serpentine é sintomático no que diz respeito à produção cultural contemporânea, e explicita tensões, que, ao longo dos doze anos de sua existência, permitiu a construção de "jóias arquitetônicas”, por vezes sem conteúdo. Podem ser encarados como a expressão de uma crise na arquitetura ou um escapismo dos arquitetos, que se lançam no campo artístico como negação à solução de problemas sociais, retomando a máxima que Hal Foster elaborou ao criticar o Museu Guggenhein de Bilbao: "o espetáculo é uma imagem acumulada a tal nível que se torna capital" 200 .

Por outro lado, este posicionamento paradoxal revela que o pavilhão é hoje exemplo de uma categoria em desenvolvimento, vinculado às possibilidades discursivas assim como Museus, galerias e exposições dedicadas exclusivamente à arquitetura, e sua pesquisa. Estes espaços operam como "plataformas operacionais", ou o local da reflexão crítica por excelência, onde se faz possível debater o papel da arquitetura em todos seus desdobramentos e para um público ampliado, o que evidencia que, nem sempre cabe à arquitetura o papel da solução de problemas sociais. Por vezes, ela pode olhar para si mesma e formular problemas filosóficos.

200 FOSTER. Apud VIDLER. 2003, pp.59. 


\title{
Referências bibliográficas.
}

\author{
Livros
}

ADRIANI-KONNERTZ-THOMAS. Joseph Beuys. Life and Works. New York: Barron's Educational Series, 1979.

ABERCOMBIE, Stanley. Mostra Internazionale di Architettura In: 11.: Journal of the Society of Architectural Historians, Vol. 68, No. 3 (September 2009), p. 404.

ALLOWAY, Lawrence. The Venice Biennale 1895-1968. From salon to goldfish bowl. Greenwich, Connecticut: The New York Graphic Society Ltd.

BENEVOLO, Leonardo - História da Arquitetura Moderna. São Paulo: Perspectiva, $4^{\circ}$ edição brasileira, 2009.

BENNETT, Tony. The birth of the museum. History, theory, politics. Oxon: Routlege, 1995.

BIRNBAUM, SHARP, HEISER. Doug Aitken. London: Phaidon, 2001.

BISHOP, Claire. Installation Art. A critical History. New York: Routledge, 2005.

BLASER, Werner. Mies Van der Rohe. São Paulo: Martins Fontes, 1994.

BONTA, Juan P. Sistemas de Significación en Arquitectura. Barcelona: Editorial Gustavo Gigli, 1977.

BOURRIAUD, Nicolas. Estética Relacional. São Paulo: Martins, 2009.

BRUNO, Giuliana. Public Intimacy: architecture and the visual arts. Cambridge, MIT Press, 2007.

CELANT, Germano (org.). Aldo Rossi:Teatri. Milão: Skira, 2012.

COLLI, /PERRONE. Espacio-Identidad-Empresa, arquitectura efímera $y$ eventos corporativos. Barcelona: Editorial Gustavo Gigli, 2003.

CHIPPERFIELD, David (org.). Common Ground: Venice Biennale of Architecture 2012. Veneza: Marsilio, 2012.

CURTIS, Penelope. Patio and Pavillion - The Place of Sculpture in Modern Architecture. Londres: Ridinghouse / The J. Paul Getty Museum, 2008.

GRASSI, TIRAVANIJA. Rirkrit. Rirkrit Tiravanija: a retrospective. Tomorrow is another fine day. Zurique: JRP-Ringier, 2007. 
FERRATER, José M. Dicionário de Filosofia. Tomo II. São Paulo: Edições Loyola, 2001 - pp.871-879.

FOSTER, Hall. The Art-Architecture Complex. London:Verso, 2011.

JENCKS, Charles. Movimentos Modernos em Arquitetura. São Paulo: Martins Fontes, 1985.

JODIDIO, Philip. Ten Years. Serpentine Gallery Pavilions. Colonia: Taschen. 2011

HARVEY, David. A Produção Capitalista do Espaço. Trad. Carlos Szlak. São Paulo, Annablume, 2006.

HEGEL, Georg W. F. A Arquitetura. Trad. Oliver Tolle. São Paulo: Edusp, 2008.

KITNIK, Alex (ed.) Dan Graham. October Files 11. Cambridge: MIT Press. 2011.

KRAUSS, Rosalind. Caminhos da escultura moderna - São Paulo: Martins Fontes, $2007,2^{\circ}$ edição.

KWON, Miwon. One Place after Another: Site-Specific Art and Locational Identity. Cambridge, MIT Press, 2002.

LIGTELIJN, Vincent (org.). Aldo Van Eyck Works. Basel; Boston; Berlim: Birkhäuser, 1999

LINDER, Mark. Nothing Lass than Literal. Architecture after Minimalism. Cambridge, MIT Press, 2004.

MATT, Gerald. Interviews. Colônia,:Verlag der Buchhandlung., Walther König, 2006.

MEYER, James. Minimalism. Londres: Phaidon, 2000.

MONEO, Rafael. Inquietação teórica e estratégia projetual na obra de oito arquitetos contemporâneos. Tradução: Flávio Coddou. São Paulo Cosac Naify, 2008.

MULAZZANI, Marco. I Padiglioni della Biennale de Venzia. Milano: Mondadori Electa, terza edizione, 2011.

NESBITT, Kate. Uma Nova Agenda para a Arquitetura - São Paulo: Cosac Naify, $2^{\circ}$ ed. rev. 2008.

OBRIST, Hans U. Uma Breve história da Curadoria. São Paulo: Bei, 2010 . Arte Agora! Em cinco entrevistas. São Paulo: Alameda, 2006. 
The Conversation Series, $n^{\circ} 20$ - Rirkrit Tiravanija. Köln:

Verlag der Buchhandlung Walter König, 2010.

OBRIST, Hans U - PEYTON-JONES, Julia. Serpentine Gallery Pavilion 2006. Londres: Verlag der Buchhandlung - Walther König at Serpentine Gallery, 2006.

Serpentine Gallery Pavilion 2012. Londres: Verlag der Buchhandlung - Walther König at Serpentine Gallery, 2012.

O'DOHERTY, Brian. No Interiro do Cubo Branco: a ideologia do espaço da arte.São Paulo: Martins Fontes, 2002.

OLIVEIRA-OXLEY-PETRY-ARCHER. Installation Art. London: Thames and Hudson, 1996.

PUENTE, Moisés. 100 Años, abellones de Exposición. Barcelona: Editorial Gustavo Gigli, 2000.

RATTENBURY, Keter (Org.). This in not architecture, media constructions. London: Routledge, 2002.

RENDELL, Jane. Art and Architecture: A Place Between. London: IB Tauris, 2006

ROSSI, Aldo. A Scientific Autobiography. Cambridge: MIT Press, 1981.

RUGOFF-McCRACKEN- PERRY (org.). Psycho Buildings, Artists take on Architecture. London: Hayward Publishing, 2008.

SOLÁ-MORALES /CIRICI / RAMOS. El Pabellon de Barcelona. Barcelona: Editorial Gustavo Gigli, 2002. $3^{\circ}$ edición.

SCOTT, Felicity D. Architecture or Techno-utopia, Politics after Modernism. Cambridge, MIT Press, 2007.

SCHAMAL, BETTUM (Org.). The Pavilion, Pleasure and Polemics in Architecture. Ostfildern: Hatje Cantz, 2009.

SCWARTZMAN-VOLZ-MOURA. PEDROSA, Adriano (org.) Através, Inhotim Centro de Arte Contemporânea. Brumadinho: Instituto Cultural Inhotim, 2008.

SEJIMA, Kazuyo (org.). People Meet in Architecture - Biennale Architettura 2010. Veneza: Marsilio, 2010.

TAFURI, Manfredo. Teorias e História da Arquietetura. Lisboa: Editora Presença, 1979.

VIDLER, Anthony. Warped Spaces. Cambridge:The MIT Press, 2001. 


\section{Artigos, Textos e Teses.}

ABERCOBIE, Stanley. $11^{\circ}$ Mostra Internazionale di Architettura. Review by: Journal of the Society of Architectural Historians, Vol. 68, No. 3, September 2009, p. 404.

BASAR, Shumon. The Strange Condition of Contemporary Conten-Crisis. In:Volume 17. Holanda: Stichting Archis Editor. 2008 - pp.26-27

BLAU, Eve. Kazuyo Sejima and Ryue Nishizawa. Inventing New Hierarchies.(2010) In: < http://www.pritzkerprize.com/sites/default/files/ file_fields/field_files_inline/2010_essay.pdf>

BRUAND, Yves: As construções de ossatura metálica e a influência norte-americana. in: Arquitetura Contemporânea no Brasil, São Paulo, Editora Perspectiva - 2 edição 1991 - p. 255-261.

BUMBARU, Dino. Remotely Sensing the Place. In: Common Pavilions: An Installation for the 13th Architecture Biennale in Venice 2012. <http://www. commonpavilions.com/pavilion-canada.html>

CAPAGNOLA, Sonia. Hans Schabus: Dig Your Own Hole. In:Flash Art 38, S/2005, p. 92-94.

CHEVRIER, Jean-Françoise. Monumento e Intimidad. El Croquis n¹29 - Herzog \& de Meuron 2002-2006, Madri: El Croquis Editorial, 2006. p. 8-21.

COHEN, Jean-Louis. A Beaux-Arts Exercise In the Giardini. In: Common Pavilions: An Installation for the 13th Architecture Biennale in Venice 2012 $<$ http://www.commonpavilions.com/pavilion-france.html> Mirror of Dreams. In: LOG n ${ }^{\circ} 20$ - Fall 2010 -Nova Iorque: Anyone Corporation, p.49-54.

Exhibitionist Revisionism - Exposing Architectural History. In: Journal of the Society of Architectural Historians, Vol. 58, No. 3, Architectural History 1999/2000 (Sep., 1999), p. 316-325.

COLOMINA, Beatriz - Architectureproduction. In: Keter Rattenburry(Org.). This in not architecture, media constructions. Londres: Routledge, 2002. p.207-221.

Beyond Pavilions. In: SCHAMAL, BETTUM (Org.).

The Pavilion, Pleasure and Polemics in Architecture. Ostfildern: Hatje Cantz, 2009, p. 64-78. 
COLOMINA, Beatriz - SMITHSON, Peter. Friends of the Future: A Conversation with Peter Smithson. October,Vol. 94, The Independent Group (Autumn, 2000), p.8-23.

CORRAL, Maria - MARTINEZ, Rosa. La Biennale di Venezia. In: Leonardo, Vol. 39, No. 2 ,2006, p. 172-173.

DILLON, Brian. Species of Spaces: Art, Architecture and environment. ,2008. In: Psycho Buildings, Artists take on Architecture. Londres: Hayward Publishing, 2008, p. 29/37.

DORFLES, Gillo. La XIII Triennale. Casabella ²90, Agosto, 1964. p.2-17.

DOUGLAS, Amelia. American Entropy: Doug Aitken's blow debris. In:Electronic Melbourne Art Journal n 1, 2005, p. 1-14.

EISENMAN, Peter. O Pós-Funcionalismo (1976)In: NESBITT, Kate. Uma Nova Agenda para a Arquitetura - São Paulo: Cosac Naify, $2^{\circ}$ ed. rev. 2008, p.97-101.

FAUCON- SAUSSET. Doug Aitken, Signs of the times. In: Art Press, n³19, Janeiro de 2006, p.23-26.

FOUCAULT, Michel. Diferent Spaces. In: Michel Foucaul Aesthetics, the essential works 2. Ed. James Faubion. Londres: Penguin Group, 1998, p. 175-185.

FERNANDES, Fernanda. "A Síntese das Artes e a Moderna Arquitetura Brasileira dos Anos 1950" In: http://www.iar.unicamp.br/ dap/vanguarda/artigos_pdf/fernanda_fernandes.pdf 05/01/2013 "Síntese da Artes e Cultura Urbana. Relações entre arte, arquitetura e cidade" In: $<$ http://www.docomomo.org.br/ seminario\%208\%20pdfs/176.pdf 05/01/2013>

GRAHAM, Dan. A arte em Relação à Arquitetura (1979), In: Org. FERREIA-COTRIM (org.) - Escritos de Artistas Anos 60/70. RJ: Jorge Zahar, 2006, p. 429-451.

GUERRA, Abílio. Mostra de Arquitetura na Bienal de 2006. <http:// vitruvius.es/revistas/read/arquitextos/07.077/305>

HASPEL, Jörg. The German Pavilion Revisited. In: Common Pavilions: An Installation for the 13th Architecture Biennale in Venice 2012< http://www. commonpavilions.com/pavilion-germany.html>

HEIZER, OPPENHEIM, SMITHSON. Discussões com Heizer, Oppenheim, Smithson 1970. In: Org. Cecília Ferreira e Cecília Cotrim 
- Escritos de Artistas Anos 60/70. RJ: Jorge Zahar, 2006, p. 429/451.

HERKENHOFF, Paulo. Saunas, 2005. In: Adriana Varejão. Chambre d'échos/Câmara de Ecos. Fondation Cartier pour l'art contemporain/Actes Sud, 2005. p. 107 - 118

Glória! O grande caldo. In: Adriana Varejão. São

Paulo:Takano Editora Gráfica, 2001.

HERTZBERGER, Herman. Northern Light. In: Common Pavilions: An Installation for the 13th Architecture Biennale in Venice $2012<$ http://www. commonpavilions.com/pavilion-netherlands.html>

JENCKS, Charles. The presence of the past. In: Revista Domus $n^{\circ} 610$, de Outubro de 1980. p. 9

KIHM,Christophe. Gestures na Territories. In: Art Press n²82 S/2002, p.46-50.

KIM-COHEM, Seth. The hole truth: Seth Kim-Cohen on Doug Aitken's Pavilion. In: Artforum International Magazine, Inc. November 1, 2009 - p. 252-253.

KOOLHAAS, Rem. Nova Iorque Delirante. São Paulo, Cosac Naify, 2008.

KRAUSS, Rosalind. Sculpture in the expanded Field. In: October, vol. 8, Spring, 1979, p.30-44 Cambridge: MIT Press, 1978, p. 277/290.

The Cultural Logic of the Late Capitalist Museum. In: October Vol. 54, Autumn, 1990, p.317-441.

LAVIN, Sylvia. Showing Work. In: LOG n²0, Fall 2010 - Nova Iorque, Anyone Corporation. p.5-10.

“Vanishing Point”In: Artforum International Magazine -

Vol. 51. Outubro 2012, p. 212-219.

LEFAIVRE, Liane. Arte Arquitectónico. Uma nueva tendência em La Bienal de Venecia. In: Arquitectura Viva n 102, 2005, p. 87-89.

LEFEBVRE, Henri. From The Production of Space. In: HAYS, Michael (ed.). Architectural Theory, since 1968. Nova Iorque: Columbia Book of Architecture, 1998 - p.174-188.

MAURÍCIO, Jayme. O Tempo Livre brasileiro na Trienal. Revista Módulo n 38, dezembro, 1964. p. 38-44.

MOSTAFAVI, Mohsen. A conversation with Kazuyio Sejima \& Ryue Nishizawa. In: El Croquis n¹55- SANAA 2008-2011.Madrid: El Croquis Editorial, 2011, p. 6-16. 
Arquitectura inorgânica. In: El Croquis n ${ }^{\circ} 155$ - SANAA

2008-2011.Madrid: El Croquis Editorial, 2011, p. 245-251.

NAVES, Rodrigo. Matthew Barney: pop, escatológico. In: O Vento e o Moinho. São Paulo: Companhia das Letras, 2007 - p. 393 - 396.

OITICICA, Helio. Tropicália (1968). In: Tropicália, Uma Revolução na Cultura Brasileira.(1967-1972). BASUALDO (org.). São Paulo, Cosac Naif 2007. p.239-241.

Esquema Geral da Nova objetividade Brasileira. In:

FERREIRA-COTRIM (org.) - Escritos de Artistas Anos 60/70. RJ: Jorge Zahar, 2006, p. 154/168.

OBRIST, Hans U. "Learning to Love London" In: Art Review . Londres, n¹ Julho, 2006, p.55.

PALLASMAA, Juhani. Aalto's Magic Lantern.In: Common Pavilions: An Installation for the 13th Architecture Biennale in Venice 2012. <http://www. commonpavilions.com/pavilion-finland.html>

PHILlIPS, Andrea. Pavilion Politics. In: LOG n²0 - Fall 2010 - Nova Iorque: Anyone Corporation. p.105-115.

ROGERS, Ernesto N. La triennale uscita del coma.In: Casabella 290, agosto, 1964. p.01.

ROSSETTI, Eduardo P. Riposatevi: a Tropicália de Lucio Costa na XIII Trienal de Milão.2005. In: CD dos anais do VI Seminário DOCOMOMO Brasil, Niterói. Disponível em: <http://www.vitruvius.com.br/revistas/ $\mathrm{read} /$ arquitextos/06.068/388>

ROSSI, Ado. Uma Arquitetura Analógica. 1976. In: NESBITT, Kate. Uma Nova Agenda para a Arquitetura. - São Paulo: Cosac Naify, $2^{\circ}$ ed. rev. 2008, pp.377-384.

Teatro del Mondo, Venezia.1979. In: CELANT, Germano (org.). Aldo Rossi:Teatri. Milão: Skira, 2012, p. 50.

La Fortuna del Teatro del Mondo, Venezia.1982. In:

CELANT. Aldo Rossi: Teatri. Milão: Skira, 2012, p. 64-66.

ROWE, Colins. SLUTZKY, Robert. Transparencia: Literal y fenomenal. (1955-56) In: Maneirismo y arquitectura moderna y otros ensayos. Barcelona: Editorial Gustavo Gigli, 1976, p.155-177.

RAHM, Philippe: Hormonorium. (2002) <http://www.philipperahm. $\mathrm{com} / \mathrm{data} / \mathrm{projects/hormonorium/index.html>}$

SCOTT, Felicity D. Operating Platforms. In: LOG n²0 - Fall $2010-$ Nova Iorque: Anyone Corporation. p.65-69. 
SMITHSON, Alison. The Nature of retreat. (1991). In: University of California: Berkley, Places 7/3, p. 8-23.

STOPPANI, Teresa. A Conversation of Many. In: CHIPPERFIELD, David (org.). Common Ground:Venice Biennale of Architecture 2012.Veneza: Marsilio, 2012, p. 83-95.

TAFURI, Manfredo. L'Ephemere Est Eternel. Aldo Rossi a Venezia. In: Domus 602, Milão,1980. p. 7-8.

TSCHUMI, Bernard. The Architectural Paradox. 1975. In: HAYS, Michael (org.). Architectural Theory, since 1968. Nova Iorque: Columbia Book of Architecture, 1998 - p.214-229.

Arquitetura e Limites I - 1980; Arquitetura e limites II1981;Arquitetura e limites III-1981; Introdução: notas para uma teoria da disjunção arquitetônica - 1988. In: NESBITT, Kate. "Uma Nova Agenda para a Arquitetura" - São Paulo: Cosac Naify, $2^{\circ}$ ed. rev. 2008, pp.173-191.

O Prazer da Arqutetura - 1977. In: NESBITT, Kate. “Uma Nova Agenda para a Arquitetura" - São Paulo: Cosac Naify, $2^{\circ}$ ed. rev. 2008, pp.573-584.

URBACH, Henry. Exhibition as Atmosfere. In: LOG n²0 - Fall $2010-$ Nova Iorque, Anyone Corporation. p.11-17.

VIDLER, Antony. Architecture's expanded field: fiding inspiration in jellyfish and geopolitics, architects today are working within radically new frames of reference. In: Artforum International Magazine, Vol. 42, 2004, pp. 147-150

Toward a Theory of the Architectural Program. In: October, $\mathrm{n}^{\circ}$ 106, Fall 2003, p.59-74.

Diagrams of Diagrams: Architectural Abstraction and Moderns Representation. In: Representations $\mathrm{n}^{\circ}$ 72, Fall 2000, University of California Press, p.1-18.

WAGNER, Anne. "Being There: Art and the Politics of Place." In: Artforum International Magazine Vol. 43, $\mathrm{n}^{\circ}$ 10, Summer 2005, p.264-269

WISNIK, Guilherme. Pavilhão Adriana Varejão. Revista Projeto Design, Edição 340 Junho de 2008. p. 72-81.

Dentro do Nevoeiro: diálogos cruzados entre arte e arquitetura contemporânea. Tese de Doutorado - Faculdade de Arquitetura e Urbanismo - FAUUSP. Orientador: Agnaldo Farias. 2012.

ZARDINI, Mirko. Exhibiting and Collecting Ideas: A Montreal Perspective. In: LOG n²0 - Fall 2010 - New York, Anyone Corporation. p.77-84.

Pavilhão de Veneza. Revista Módulo nº 38, dezembro, 1964. p.32-37 


\section{Vídeos}

LOBATO - CAMPOLINA - MAGALHÃES. Adriana Varejão.

Pavilhão (2008). DVD, Série Retrato. (20min.40s.)som., color.

“Beatriz Colomina. The museum after art." In: Forum Permanente, 2011. <http://200.144.185.10:9990uspyrEvj1yQVJOgK8djAe8Wq7YTuwarg8t $6 \mathrm{UwUamTtmsjc.WMV?data \_ proto}=$ HTTP\&rota=>

\section{Índice de imagens.}

gráfico 1 - p. 19 :

Campo Ampliado.

In: "Escultura no Campo Ampliado" - Elizabeth Carbone

Baer publicado na Revista Gávea n 1 da PUC-RJ.

figuras 1 e 2 - p. 22:

Mary Miss. Perimeters/Pavillions/Decoys. 1977-1978

In: <http://www.marymiss.com/index_.html>

\section{figura 3 - p.24:}

Diller Scofidio + Renfro. Blur Building, 2002.

In: <http://www.dillerscofidio.com/>

\section{figuras 4 e 5 - p.30:}

Gerrit Rietveld. Pavilhão de esculturas. Kröller-Müller Museum -1965 In:

$<$ http://www.archdaily.com/81555

rietveld-pavilion-at-the-kroller-muller-sculpture-garden/>

figuras 6,7 e 8 - p.34:

Aldo Van Eyck - Pavilhão de esculturas para Sonsbeek Park - 1965 In: LIGTELIJN(org.). Aldo Van Eyck Works. Basel; Boston; Berlim: Birkhäuser, 1999. p.134,137,139.

figura 9 - p.36:

Carl Andre, 8 Cuts, 1967

MEYER, James. Minimalism. Londres: Phaidon, 2000, p. 98.

figuras 10 e 11 - p.46:

Bernard Tschumi. Projeto do parque La Villete e Follie 1982-1998 In: <http://www.tschumi.com/projects/3/> 
figura 12 - p. 50 :

Mies Van der Rohe, Plan of Exhibition, 1947

In:

$<$ http://www.facebook.com/photo.php?fbid=10151234992140379\&set $=$ a. 10150 620265840379.432927.56200560378\&type $=1 \&$ theater $>$

figura 13 - p. 52:

Lucio Costa. Riposatevi -1964.

In:< http://www.jobim.org/lucio/bitstream/handle/2010.3/305/

III\%20A\%2047-00149\%20L.jpg?sequence=3>

\section{figura 14 - p.52:}

Hélio Oiticica.Tropicália PN2 e PN3. MAM - Centro Itaú Cultural, 2010. In: <http://bravonline.abril.com.br/materia/helio-oiticica-museu-mundo $>$

\section{figura 15 - p.56:}

El Lissitzky, Proun Room - Van Abbemuseum, 1971.

In: < http://www.vanabbemuseum.nl/typo3temp/pics/E_f9c96ca358.jpg>

figura 16 - p. 56:

Marcel Duchamp.Exposition International du Surréalisme, Paris -1938.

In: <https://ruinsandrecyclings. wikispaces.com/Tatjana+Leboff>

\section{figura17 - p.56:}

Kurt Schwitters, Merzbau, 1932.

In: RUGOFF-McCRACKEN- PERRY (org.). Psycho Buildings. Artists take on Architecture. Londres: Hayward Publishing.2008. p 36.

figura18 - p.58:

Alison e Peter Smithson, Nigel Henderson e Eduardo Paolozzi.

Patio and Pavilion - 1956.

In: < http://oaj.oxfordjournals.org/content/29/2/269/F13.large.jpg>

\section{figuras 19 e 20 - p.62:}

Mies Van der Rohe. Pavilhão de Barcelona -1929

In: http://1.bp.blogspot.com/__ghOVo_CXss/TXtBK_CgadI/

AAAAAAAADNo/I12GrbJvp4M/s1600/Mies_y_Alfonso_XIII_01.jpg

\section{figura 21 - p.62:}

Dan Graham. Public Spaces, Two Audiences - 1976.

In: KITNIK, Alex (ed.) Dan Graham. October Files 11. Cambridge: MIT Press. 2011.p 44.

\section{figura 22 - p.62:}

Dan Graham. Pavilion/ Sculputure Aragonne - 1978-1981

In:Artforum International Magazine - Vol. 51. Outubro 2012, p. 212. 


\section{figura 23 - p.70:}

Situação atual dos pavilhões do Giardino, Veneza.

In: MULAZZANI, Marco. I Padiglioni della Biennale de Venzia. Milano: Mondadori Electa, terza edizione, 2011, p.18.

figura $24-$ p.73:

Fausto Finzi. Pavilhão França - 1912

In: < http://www.commonpavilions.com/pavilion-france.html>

\section{figura 25 - p.74:}

Ernest Haiger. Pavilhão da Alemanha - 1938

In: <http://www.commonpavilions.com/pavilion-germany.html>

figura 26 - p.75:

Hans Haack. Germania - 1993

In: <http://put.edidomus.it/domus/binaries/imagedata/big_266395_1569_84.jpg>

figura 27 - p.77:

Josef Hoffmann. Pavilhão Áustria - 1934

In: < http://www.commonpavilions.com/pavilion-austria.html>

figura 28 - p.77:

Hans Schabus. "The Last Land" - 2005

In: <http://www.biennale-schabus.at/images/dasletzteland_1_496.jpg>

figura 29 - p.80:

Gerrit Rietveld. Pavilhão Holanda - 1954

In: <http://www.commonpavilions.com/pavilion-netherlands.html>

figura 30 - p.80:

Alvar Aalto. Pavilhão Finlândia - 1956

In: <http://www.commonpavilions.com/pavilion-finland.html>

figura 31 - p.82:

Sverre Fehn. Pavilhão dos Países Nórdicos - 1962

In: <http://farm8.staticflickr.com/7136/6899489968_c5d43b63de_z.jpg>

figura 32 - p.83:

Henrique Mindlin e equipe. Implantação do Pavilhão Brasil - 1966

In:<http://brasilartesenciclopedias.com.br/tablet/nacional/images/ mindlin_henrique05.jpg>

figura 33 - p.85:

Carlo Scarpa. Pavilhão Venezuela - 1952

In: < http://www.commonpavilions.com/pavilion-venezuela.html> 
figura 34 - p.85:

BBPR Pavilhão Canadá - 1958

In:< http://www.commonpavilions.com/pavilion-canada.html>

figura 35 - p.90:

Décosterd \& Rahm. "Hormonorium”, Pavilhão Suíça - 2002

In: http://www.philipperahm.com/data/projects/hormonorium/index.html

figura 36 - p.90:

Patrick Bouchain. "Metavilla”, Pavilhão França - 2006

In: <http://www.1024architecture.net/1024/wp-content/

uploads/2010/02/METAsauna-cyrille-weiner-01-600x400.jpg>

figura 37 - p.94:

Petra Blaisse. Re-set, Pavilhão Holanda - 2012

In: <http://put.edidomus.it/domus/binaries/imagedata/

big_394003_5856_1.\%2012BiV_9_cRtHart_7_ROB7918_the-black-and-

white-tranparency-following-a-warm-pink-glow.jpg>

\section{figura 38 - p.94:}

Mies Van der Rohe e Lilly Reich. Velvet and Silk Café - 1927

In: < http://media.tumblr.com/tumblr_lmgni4Qu1c1qc159b.jpg>

figuras 39 e 40 - p.99:

Siza Vieira. Pavilhão para a Bienal de Veneza - 2012

In:<http://www.archdaily.com/267598/venice-biennale-2012-alvaro-siza/>

figura 41 - p.100:

Eduardo Souto de Moura. Pavilhão para a Bienal de Veneza - 2012

In: <http://www.archdaily.com/267891/

venice-biennale-2012-eduardo-souto-de-moura/>

figura 42 - p.101:

Eduardo Souto de Moura.

Projeto para o Pavilhão para a Bienal de Veneza - 2012

Material cedido para circulação acadêmica pelo escritório do arquiteto.

figura 43 - p.102:

Aires Matheus. Radix - 2012

Fotografia cedida pelo escritório Aires Matheus para divulgação do projeto.

figura 44 - p.103:

Aires Matheus. Projeto para Radix - 2012

Material cedido para circulação acadêmica pelo escritório do arquiteto. 
figura 45 - p.106:

Aldo Rossi. Teatro del Mondo - 1979-1980

In: <http://www.deconcrete.org/wp-content/uploads/2010/04/teatro-del-mundo2.jpg>

figura 46 - p.112:

Dan Graham. Bisected Triangle- 2002

In: <http://www.inhotim.org.br/arte/obra/view/177>

figura 47 - 112:

Olafur Eliasson. By Means of a Sudden Intuitive Realization - 1996

In: <http://www.inhotim.org.br/img/ffb00dd7fe9c0e33417a8a89b6ddd250_0.jpg>

figura 48 - p.113:

Valeska Soares, Folly - 2005/2009

In: <http://leonardofinotti.blogspot.com.br/2010/10/valeskasoares-folly-at-inhotim.html>

\section{figura 49 - p.113:}

Rirkrit Tiravanija, Palm Pavilion - 2006/2008

In: <http://www.inhotim.org.br/hotsites/inauguracao/index.php/ obras/view/12>

figura 50 - p.120:

Paula Zasnicoff. Pavilhão "Neither", modelo, planta e corte transverso, 2006. Material cedido pela arquiteta mediante autorização do Inhotim.

figura 51 - p.121:

Carlos Granado, Pavilhão "Neither", modelo, planta e corte transverso 2006. Material cedido por Paula Zasnicoff mediante autorização do Inhotim.

figura 52 - p.123:

Doug Aitken, estudo preliminar para Sonic Pavilion - 2006. Material cedido por Paula Zasnicoff mediante autorização do Inhotim.

figura 53 - p.125:

Doug Aitken, “New Ocean"- 2001

In: < http://photography-now.com/images/Bilder/gross/T00815B000289.jpg>

figura 54 - p.125:

Doug Aitken, “No History"- 2005

In: <http://www.tb-cms.org/data/artwork/7/10674_artwork_detail.jpg> 


\section{figura 55 - p.126:}

Doug Aitken. "Sonic Pavilion" - 2002

In: < http://inhotim.blogspot.com.br/2009/10/nove-novos-destinosdoug-aitken.html>

\section{figura 56 - p.128:}

Paula Zasnicoff. Planta executiva. Sonic Pavilion - 2008

Material cedido pela arquiteta mediante autorização do Inhotim.

\section{figura 57 - p.129:}

Paula Zasnicoff. Cortes executivos. Sonic Pavilion - 2008

Material cedido pela arquiteta mediante autorização do Inhotim.

\section{figuras 58 - p.132:}

Matthew Barney. De Lama Lâmina -2004

In: < http://dbprng00ikc2j.cloudfront.net/

userimages/3151/20100830142836-Hoist_Greenman_DLL_press.jpg>

\section{figuras 59 - p. 132:}

Mathew Barney. Drawing Restraint -1987

In: < http://img.ffffound.com/static-data/assets/6/cd86a331656a0c4 9851aaed6c8027a4bf5069d8d_m.jpg>

\section{figura 60 - p. 134:}

Matthew Barney, Pavilhão De Lama Lâmina -2004/2009

In: http://www.inhotim.org.br/index.php/arte/obra/view/360

\section{figura 61 - p. 134 :}

Drop-City -1969

In: < http://mediastore.magnumphotos.com/CoreXDoc/MAG/ Media/TR2/4/b/1/7/NYC66804.jpg>

\section{figura 62 - p.137:}

Mathew Barney. Estudo preliminar para o Pavilhão De Lama Lâmina 2005. Material cedido por Paula Zasnicoff mediante autorização do Inhotim. 


\section{figura 63 - p.138:}

Paula Zasnicoff/ Tensor Estrutura Especiais. Detalhes construtivos - 2008. Material cedido por Paula Zasnicoff mediante autorização do Inhotim

\section{figura 64 - p.140:}

Rodrigo Cerviño Lopez. Pavilhão Adriana Varejão - 2008.

In: < http://www.livingdesign.net.br/wp-content/uploads/2009/11/ 276c2c7e2aa2cf3006310a515ddf85de.jpg>

\section{figura 65 - p.142:}

Adriana Varejão. "Linda do Rosário” - 2004 e "Carnívoras”- 2008

In: < http://static.dezeen.com/uploads/2009/03/pavillion-byrodrigo-cervino-lopes-22.jpg $>$

\section{figura 66 - p.142:}

Adriana Varejão. "Linda do Rosário" - 2004 e "O Colecionador" - 2008.

In: < http://static.dezeen.com/uploads/2009/03/pavillion-by-rodrigocervino-lopes-26.jpg $>$

\section{figura 67 - p.144:}

Adriana Varejão. "Celacanto Provoca Maremoto" - 2008

In: < http://static.dezeen.com/uploads/2009/03/pavillion-byrodrigo-cervino-lopes-31.jpg $>$

\section{figura 68 - p.146:}

Dan Graham. "Two Way Mirror and Hedge Labyrinth" - 1989

In: < http://www.vulgare.net/wp-content/uploads/2010/10/ dangraham1.jpg $>$

\section{figura 69 - p. 154 :}

Rem Koolhaas e Cecil Balmod. Pavilhão Serpentine - 2006

In:JODIDIO, Philip. Ten Years. Serpentine Gallery Pavilions. Colonia: Taschen. 2011, p.VII 7.

\section{figuras 70 e 71 - p. 156}

Rem Koolhaas e Cecil Balmod.

Planta e corte de estudo para o Pavilhão Serpentine - 2006

In:JODIDIO, Philip. Ten Years. Serpentine Gallery Pavilions. Colonia: Taschen. 2011, p.VII 25, VII 30. 
figura 72 - p. 158:

Rem Koolhaas e Cecil Balmod. Pavilhão Serpentine - 2006

In: <http://farm1.staticflickr.com/86/249018739_1dee6b225c_z. jpg?zz=1>

\section{figura 73 - p.158:}

Thomas Demand. Vista interna da Exposição. - 2006.

In: $<$ http://www.art-it.asia/p/admin_ed_columns_e/U9tHOSKrPGVFedyncT4L/3. jpg>

\section{figura 74 - p. 161:}

Archigram. Instant City - 1968

In: < http://ad009cdnb.archdaily.net/wp-content/ uploads/2012/06/1340656798-archigram4.jpg

\section{figura 75 - p. 163:}

Yves Klein. Monocromo e fogo, Air Architecture - 1961

In: < http://www.yveskleinarchives.org/works/large/archi30.jpg>

\section{figura 76 - p.164:}

SANAA. Pavilhão Serpentine - 2009

In:JODIDIO, Philip. Ten Years. Serpentine Gallery Pavilions. Colonia:

Taschen. 2011, p. X08-09.

\section{figuras 77 e 78 - p.167:}

SANAA. Croquis para o Pavilhão Serpentine - 2009

In:JODIDIO, Philip. Ten Years. Serpentine Gallery Pavilions. Colonia: Taschen. 2011, p. X12, X25.

\section{figuras 79 - p.: 169:}

SANAA. Maquetes de estudo para o Pavilhão Serpentine - 2009

In:JODIDIO, Philip. Ten Years. Serpentine Gallery Pavilions. Colonia: Taschen. 2011, p. X 28.

\section{figura 80 - p. 170:}

Herzog e De Meuron e Ai Weiwei. Pavilhão Serpentine - 2012

In:OBRIST/PEYTON-JONES. Serpentine Gallery Pavilion 2012.

Londres: Verlag der Buchhandlung - Walther König at Serpentine Gallery, 2012, p.20-21.

\section{figura 81 - p. 172:}

Herzog \& De Meuron. Estrutura II - 2007/2006.

In: < 6a00d8341c630a53ef0120a5cd3d5f970c-500wi> 
figuras 82 e 83 - p.175:

Herzog \& De Meuron e Ai Weiwei.

Maquetes de Estudo par o Pavilhão Serpentine - 2012

In:OBRIST/PEYTON-JONES. Serpentine Gallery Pavilion 2012.

Londres: Verlag der Buchhandlung - Walther König at Serpentine Gallery, 2012, p.54, p.57.

figuras 84 e 85 - p. 177:

Herzog \& De Meuron e Ai Weiwei.

Desenhos processuais para o Pavilhão Serpentine - 2012

Modelo em baixo relevo de cortiça com a topografia do Pavilhão Serpentine - 2012

In:OBRIST/PEYTON-JONES. Serpentine Gallery Pavilion 2012.

Londres: Verlag der Buchhandlung - Walther König at Serpentine Gallery, 2012, p.72-73, p. 